\title{
DIRETRIZES PARA O GERENCIAMENTO DE RISCOS EM CONTRATOS DE OBRAS PÚBLICAS: ESTUDO DE CASO DA CONTRATAÇÃO INTEGRADA
}

\author{
DANIEL MATOS CALDEIRA
}

DISSERTAÇÃO DE MESTRADO EM ESTRUTURAS

E CONSTRUÇÃO CIVIL DEPARTAMENTO DE ENGENHARIA CIVIL E AMBIENTAL

\section{FACULDADE DE TECNOLOGIA UNIVERSIDADE DE BRASÍLIA}


UNIVERSIDADE DE BRASÍLIA

FACULDADE DE TECNOLOGIA

DEPARTAMENTO DE ENGENHARIA CIVIL E AMBIENTAL

DIRETRIZES PARA O GERENCIAMENTO DE RISCOS EM CONTRATOS DE OBRAS PÚBLICAS: ESTUDO DE CASO DA CONTRATAÇÃO INTEGRADA

DANIEL MATOS CALDEIRA

ORIENTADORA: DSC. MICHELE TEREZA MARQUES CARVALHO

DISSERTAÇÃO DE MESTRADO EM ESTRUTURAS E CONSTRUÇÃO CIVIL

PUBLICAÇÃO: E.DM - 021A/15

BRASÍLIA/DF: OUTUBRO DE 2015 


\section{UNIVERSIDADE DE BRASÍLIA \\ FACULDADE DE TECNOLOGIA \\ DEPARTAMENTO DE ENGENHARIA CIVIL}

DIRETRIZES PARA O GERENCIAMENTO DE RISCOS EM CONTRATOS DE OBRAS PÚBLICAS: ESTUDO DE CASO DA CONTRATAÇÃO INTEGRADA

\section{DANIEL MATOS CALDEIRA}

DISSERTAÇÃO SUBMETIDA AO DEPARTAMENTO DE ENGENHARIA CIVIL E AMBIENTAL DA FACULDADE DE TECNOLOGIA DA UNIVERSIDADE DE BRASÍLIA COMO PARTE DOS REQUISITOS NECESSÁRIOS PARA A OBTENÇÃO DO GRAU DE MESTRE EM ESTRUTURAS E CONSTRUÇÃO CIVIL.

APROVADA POR:

Prof' Michele Tereza Marques Carvalho, DSc (UnB)

(Orientadora)

Prof André Luiz Aquere de Cerqueira e Souza, DSe (UnB)

(Examinador Interno)

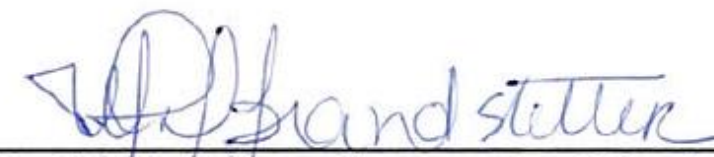

Prof $^{\mathrm{a}}$ Maria Carolina Gomes de Oliveira Brandstetter, DSc (UFG) (Examinadora Externa)

BRASÍLIA/DF, 16 DE OUTUBRO DE 2015 
Dedico este trabalho à minha esposa Giselle e ao meu filho Daniel Filho pelo sentido que dão à minha vida e por me fazerem o homem mais feliz do mundo. 


\section{AGRADECIMENTO}

À Deus, pela presença constante em minha vida.

Especialmente à minha amada mãe que me incentiva a estudar desde os tempos de préescola e a valorizar o conhecimento, o mérito e o esforço.

Agradeço à Professora Michele, pela brilhante orientação, traduzidas em atenção, paciência, marcantes contribuições e pela dedicação em ter me guiado na direção correta para a melhor realização, transformando ideias em material concreto.

Aos professores do Programa de Pós-graduação em Estruturas e Construção Civil da Universidade de Brasília pelos conhecimentos repassados.

Agradeço aos meus ex-chefes, coordenadores na CGU, José Antônio Meyer Pires Júnior e João Carlos Figueiredo Cardoso pela compreensão e incentivo para realização deste trabalho.

Agradeço ao Diretor da CGU, Wagner Rosa da Silva, cujo apoio foi pilar de sustentação e força necessária sempre que precisei.

Ás equipes técnicas de engenharia do Banco do Brasil, Conab, EPL, FNDE, Infraero, Ministério da Integração, Valec e em especial a do DNIT, na pessoa do ex-Diretor Executivo Tarcísio Gomes de Freitas.

Agradeço ao colega mestrando do PPGT/UnB Jean Marlo Pepino de Paula pela disponibilidade em ajudar e pela incomensurável contribuição na formatação e organização do $1^{\circ}$ Fórum de Debates sobre Riscos em Obras Públicas da Universidade de Brasília.

Aos colegas do PECC/UnB Daniel Andrade, Elier Pavon, Henrique Guglielmi, Manuel Alejandro, Márcio Lemos, Maria Cláudia, Mário Sérgio, Rogério Calazans, Walter Segond e Waldir Belisário.

À amiga Eva, pelo apoio junto ao Programa de Pós Graduação em Estruturas e Construção Civil. 


\title{
RESUMO
}

\section{DIRETRIZES PARA O GERENCIAMENTO DE RISCOS EM CONTRATOS DE OBRAS PÚBLICAS: ESTUDO DE CASO DA CONTRATAÇÃO INTEGRADA}

\author{
Autor: Daniel Matos Caldeira \\ Orientadora: DSc. Michele Tereza Marques de Carvalho \\ Programa de Pós-Graduação em Estruturas e Construção Civil - UnB \\ Brasília, 16 de Outubro de 2015.
}

As recentes alterações legislativas promovidas na área de licitações de obras públicas trazidas com a aprovação da Lei $n^{\circ}$ 12.462/2011, estabeleceram no ordenamento jurídico brasileiro um novo regime de execução de obras públicas, denominado contratação integrada. Nesse contexto, o presente trabalho objetivou consolidar e analisar criticamente os principais aspectos observados sobre o tema gerenciamento de riscos em diretrizes que fomentem o aprimoramento da gestão pública por meio de contribuições ao planejamento de licitações efetuadas nesta modalidade de contratação.

De acordo com a sequência de etapas do método de pesquisa empregado foram levantados o conjunto de licitações realizadas nessa modalidade e elaboradas matrizes de avaliação do nível de maturidade dos órgãos visando com isso a avaliação das metodologias de precificação de riscos instituídas. Da análise realizada, verificou-se que o tema gerenciamento de riscos ainda não está bem entendido e difundido na Administração Pública Federal.

Ao final foram propostas diretrizes para o gerenciamento de riscos em contratos dessa modalidade, levando em consideração o resultado da consolidação dos principais aspectos observados nas etapas anteriores e tendo como base um modelo referencial de gerenciamento de projetos e riscos, as práticas internacionais de contratação e avaliação de contingências e o arcabouço legal e jurisprudencial brasileiro para obras públicas.

Palavras-Chave: Gerenciamento; Riscos; Obras Públicas, Contratação Integrada. 


\title{
ABSTRACT \\ GUIDELINES FOR RISK MANAGEMENT IN PUBLIC WORKS CONTRACTS: CASE STUDY OF DESIGN-BUILD
}

\author{
Author: Daniel Matos Caldeira
}

Supervisor: DSc. Michele Tereza Marques de Carvalho

Post-Graduate Program on Structures and Civil Construction - UnB

Brasília, 16 October 2015.

Recent legislative changes introduced in the area of public works bids brought with the approval of Law no. 12.462/2011, established the Brazilian legal system a new enforcement regime for public works, called integrated contracts (Design-Build, in English). In this context, this study aimed to consolidate and critically analyze key aspects observed on the topic of risk management in guidelines that promote the improvement of governance through contributions to the planning of bids made on this type of contract.

According to the sequence of employee research method steps have been raised the number of bids made in this modality and elaborate arrays of evaluation of organ maturity level targeting with this assessment of pricing methodologies established risks. Of the analysis, it was found that the risk management theme is still not well understood and widespread in the Federal Public Administration.

At the end it was proposed guidelines for risk management in contracts of this type, taking into account the result of the consolidation of key aspects observed in the previous steps and based on a reference model of project management and risks, international practice of hiring and evaluation contingencies and the Brazilian legal and judicial framework for public works.

Keywords: Management; Risks; Public Works, Design-Build. 


\section{SUMÁRIO}

1 INTRODUÇÃO............................................................................................................ 1

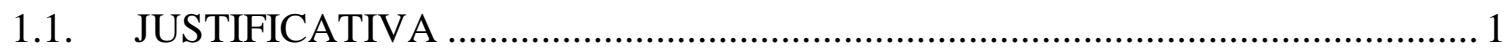

1.2. OBJETIVOS DA PESQUISA …………………………………………. 3

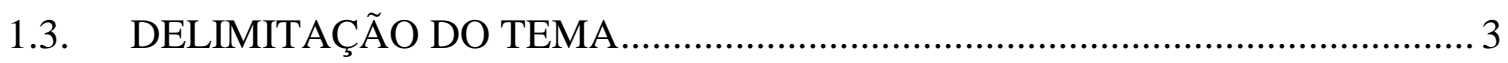

1.4. ESTRUTURA DO TRABALHO ...............................................................

2. REVISÃO BIBLIOGRÁFICA _................................................................... 7

2.1. MODELOS DE GERENCIAMENTO DE PROJETOS E RISCOS ....................... 7

2.2. ARCABOUÇO LEGAL E JURISPRUDENCIAL BRASILEIRO …………….... 18

2.3. PRÁTICAS INTERNACIONAIS PARA CONTRATAÇÃO E AVALIAÇÃO DE

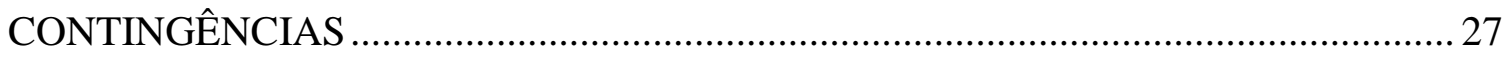

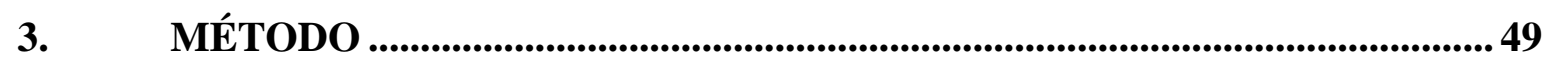

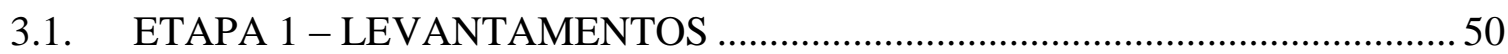

3.2. ETAPA 2 - FÓRUM DE DEBATES SOBRE RISCOS …………………............. 60

3.3. ETAPA 3 - MATRIZES DE AVALIAÇÃO DO NÍVEL DE MATURIDADE.. 61

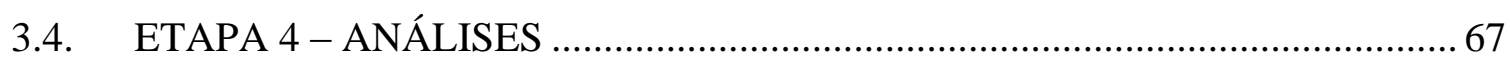

3.5. ETAPA 5 - DIRETRIZES PARA O GERENCIAMENTO DE RISCOS ............ 71

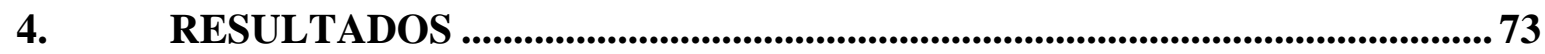

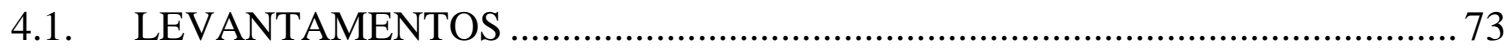

4.2. PRIMEIRO FÓRUM DE DEBATE SOBRE RISCOS EM OBRAS PÚBLICAS

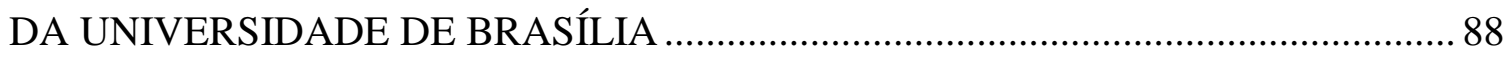

4.3. MATRIZES DE AVALIAÇÃO DO NÍVEL DE MATURIDADE ......................90

4.4. ANÁLISE CRÍTICA DAS FISCALIZAÇÕES DO TRIBUNAL DE CONTAS

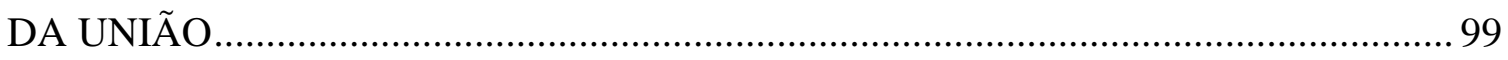

4.5. DIRETRIZES PARA O GERENCIAMENTO DE RISCOS ………………....... 116

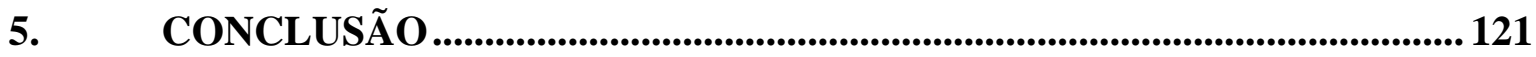

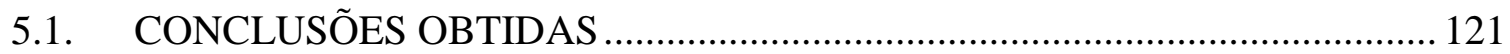

5.2. SUGESTÕES PARA TRABALHOS FUTUROS ……………………………..... 122

6. REFERÊNCIAS BIBLIOGRÁFICAS.............................................................. 124

GLOSSÁRIO …………................................................................................................................. 137 
APÊNDICE I - ACÓRDÃO 2622/2013-TCU-PLENÁRIO............................................. 141 APÊNDICE II - CLASSIFICAÇÃO DE ESTIMATIVAS DE CUSTO ....................... 155 APENDICE III - ACÓRDÃOS DO TCU ..................................................................... 160 APÊNDICE IV - LICITAÇÕES CONTRATAÇÃO INTEGRADA ............................. 164 


\section{LISTA DE FIGURAS}

Figura 2.1 - Base Legal de suporte para as várias possibilidades de financiamento........... 19

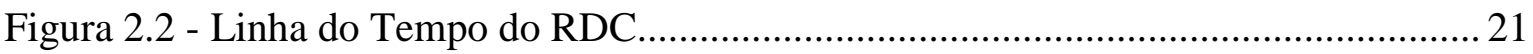

Figura 2.3 - Comparação entre as formas de contratação Design-Bid-Build e Design-Build.

Figura 2.4- Percentual de contratações na modalidade Design-Build por setor.

Figura 3.1 - Fluxograma do método de pesquisa.

Figura 3.2 - Cenários de Maturidade em relação as fases de identificação e análise quantitativa de riscos. .64

Figura 3.3 - Cenários de Maturidade em relação à fase de planejamento de respostas aos riscos.

Figura 4.1 - Cenários de Maturidade em relação as fases de identificação e análise quantitativa de riscos 90

Figura 4.2 - Cenários de Maturidade em relação à fase de planejamento de respostas aos riscos 


\section{LISTA DE QUADROS}

Quadro 2.1 - Processos de gerenciamento de projetos - áreas 1 a 4 .................................. 9

Quadro 2.2 - Processos de gerenciamento de projetos - áreas 5 a 10 ............................... 10

Quadro 2.3 - Processos de gerenciamento de riscos por modelo ....................................... 12

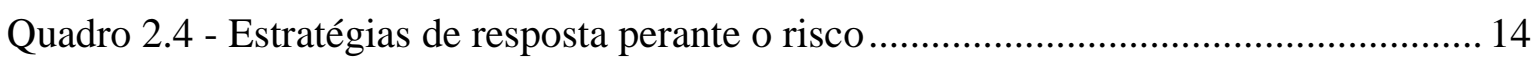

Quadro 2.5 - Escala de contingência por fase de desenvolvimento do orçamento .............. 16

Quadro 3.1 - Licitações por órgão/entidade do Poder Executivo Federal efetuadas na

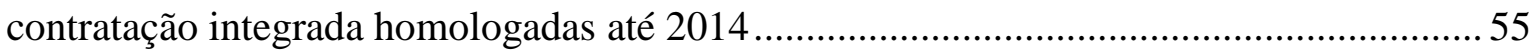

Quadro 3.2 - questões de auditoria por fase de contratação ...............................................69

Quadro 4.1 - Relação dos Relatórios encaminhados ao Congresso Nacional nos ciclos Fiscobras de 2013 e 2014 referentes ao tema contratação integrada................................... 79

Quadro 4.2 - Quantitativo de licitações na modalidade contratação integrada publicadas após a Medida Provisória ${ }^{\circ}$ 630, de 24/12/2013 e homologadas até 2014 ........................ 92

Quadro 4.3 - questões de auditoria por fase de contratação ............................................. 104 Quadro 4.4 - Relatórios de Fiscalização e Acórdãos que abordam o tema gestão de riscos e seguros e garantias 


\section{LISTA DE TABELAS}

Tabela 2.1 - Faixas percentuais das parcelas de i) risco e ii) seguro e garantia contidas na taxa de BDI por tipologia de obra

Tabela 2.2 - Faixas percentuais das parcelas de i) risco e ii) seguro e garantia contidas na taxa de BDI para contratação de fornecimento de materiais e equipamentos ...................... 25

Tabela 2.3 - Parâmetros para avaliação do grau de competição de um certame .................. 32

Tabela 2.4 - Intervalo para o orçamento de referência da Administração............................. 33

Tabela 2.5 - Comparação entre as metodologias de entrega de Projetos Design-Build (DB) e a Design-Bid-Build (DBB) 39

Tabela 3.1 - Quantitativo de licitações homologadas na modalidade contratação integrada

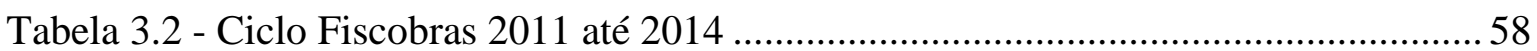

Tabela 3.3 - Relatórios por empreendimentos e por Órgão/Entidade ................................. 59

Tabela 3.4 - Quantidade de constatações e os acórdãos por relatório e por empreendimento

Tabela 3.5 - Relação da quantidade de questões de auditoria por empreendimento 68

Tabela 3.6 - Percentual das constatações por fase de contratação

Tabela 3.7 - Relatórios de Fiscalização e Acórdãos que abordam o tema gestão de riscos e seguros e garantias

Tabela 4.1 - Quantitativo de licitações homologadas na modalidade contratação integrada

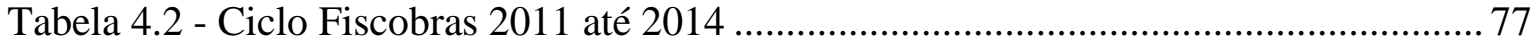

Tabela 4.3 - Relatórios por empreendimentos e por Órgão/Entidade ................................ 80

Tabela 4.4 - Quantidade de constatações por relatório e por empreendimento.................... 83

Tabela 4.5 - Quantidade de acórdãos por relatório e por empreendimento.......................... 85

Tabela 4.6 - Relação da quantidade de questões de auditoria por empreendimento .......... 100

Tabela 4.7 - Percentual das constatações por fase de contratação..................................... 105

Tabela 4.8 - Constatações referentes ao Processo Licitatório ............................................ 106

Tabela 4.9 - Constatações referentes à Fiscalização.......................................................... 107

Tabela 4.10 - Constatações referentes ao Anteprojeto de Engenharia .............................. 108 


\section{INTRODUÇÃO}

Esse trabalho destaca a relevância do tema riscos, como elemento central do processo de orçamentação de obras públicas licitadas no âmbito da contratação integrada.

Tal centralidade emerge a partir de recentes alterações legislativas que instituíram em nosso ordenamento jurídico um novo regime de contratação de obras públicas, o RDC Regime Diferenciado de Contratações Públicas, por intermédio da Lei $\mathrm{n}^{\circ} 12.462$, de 4/8/2011.

Nos termos desse novo regramento, ganha destaque o instituto da contratação integrada, como forma de ajuste preferencial para a contratação de obras e serviços de engenharia.

A utilização do regime de execução de obra intitulado contratação integrada está intrinsicamente relacionado com o incentivo a inovação e a repartição objetiva de riscos entre as partes, contratante e contratada, como decorrência direta do fato de que tanto o projeto quanto a execução da obra ou serviço ficaram a cargo do contratado.

É no âmbito da contratação integrada que este trabalho focaliza a promoção de discussões e reflexões acerca dos parâmetros e ferramentas que envolvem o gerenciamento de riscos, especialmente no que tange a estimação do custo de anteprojetos de engenharia e a alocação quantitativa dos riscos na formação do preço de uma obra pública.

Em síntese, tal abordagem se dará por meio do confronto das premissas conceituais e teóricas do processo de gerenciamento de riscos com os valores observados nos empreendimentos licitados pela Administração Pública Federal por meio da modalidade contratação integrada.

\subsection{JUSTIFICATIVA}

Com a proposta de simplificar as licitações insculpidas sob a égide do atual diploma de licitações e contratos - a Lei ${ }^{\circ}$ 8.666, de 21/6/1993, e agilizar a realização das obras necessárias aos megaeventos esportivos, de projeção internacional, notadamente a Copa do Mundo de Futebol e as Olimpíadas, assinou-se, em 4/8/2011, a Lei ${ }^{\circ} 12.462$, que instituiu o Regime Diferenciado de Contratações Públicas (RDC). 
Ademais, há um grande esforço do parlamento em modernizar todo o arcabouço normativo de licitações e contratos, em grande medida se valendo das inúmeras inovações acrescidas pelo RDC, inclusive as mais recentes, como é o caso dos dispositivos de precificação e alocação de riscos.

Em função da instituição dessa nova legislação, a "Engenharia Pública" nacional vivencia um novo momento histórico, não só pela retomada das grandes obras, mas, sobretudo porque se está diante de rupturas de paradigmas que antecedem a criação de um novo regime de licitações em substituição a Lei 8.666/1993 e que terá como pano de fundo justamente as inovações trazidas pelo RDC.

Zymler e Dios (2013) afirmam que o RDC é um "balão de ensaio" para uma revisão ampla da metodologia de contratações públicas.

Conforme Bittencourt (2012), esse novo regime trouxe para o ordenamento jurídico licitatório nacional, ainda que provisoriamente, inúmeras inovações e, como não poderia deixar de ser, questões polêmicas que passaram a ser debatidas em várias frentes.

Na mesma linha de argumentação, Sundfeld (2013) assinala que o RDC não veio para salvar a Copa do Mundo, mas a Copa que se colocou como uma janela de oportunidades para uma necessária reforma da lei de licitações - a lei 8.666, embora muitos críticos o tenham entendido como uma espécie de lei de ocasião, formulada às pressas para permitir, a qualquer custo, a realização da Copa de 2014 e da Olimpíada de 2016.

Desta forma, são de grande importância os estudos conduzidos no sentido de desenvolver e aprimorar o conhecimento e debate sobre a avaliação de alternativas e análises comparativas das metodologias de precificação de riscos em relação ao nível de maturidade dos órgãos, visto que tais aspectos ganham relevo no contexto do novo regime de contratações de obras públicas RDC.

Apesar de já se verificar a publicação de relevantes livros sobre o tema, como Bittencourt (2012), Cammarosano et al (2012), Junior e Dotti (2015), Justen Filho e Pereira (2012), Moreira e Guimarães (2012), Motta e Bicalho (2012), Ribeiro et al (2012), Rosilho (2013), Sundfeld (2013) e Zymler e Dios (2013), dentre outros, existem muitas lacunas sobre o tema, uma vez que os citados autores se detiveram notadamente aos aspectos jurídicos do novo regime. 


\subsection{OBJETIVOS DA PESQUISA}

O objetivo principal deste trabalho é consolidar e analisar criticamente os principais aspectos observados sobre o tema gerenciamento de riscos em diretrizes que fomentem o aprimoramento da gestão pública por meio de contribuições ao planejamento de licitações efetuadas na modalidade contratação integrada.

Dentro desse objetivo geral, apresentam-se os seguintes objetivos específicos:

i) Elaborar um instrumento (matriz) de avaliação do nível de maturidade dos órgãos em relação ao gerenciamento de riscos tendo como métrica as inovações instituídas no arcabouço legal e jurisprudencial de contratação de obras públicas;

ii) Avaliar as metodologias de precificação de riscos em relação aos níveis de maturidade instituídos pelos órgãos da Administração Pública Federal com base em um modelo referencial de gerenciamento de projetos e riscos e nas práticas internacionais de contratação e avaliação de contingências; e

iii) Identificar se as fiscalizações realizadas pelo Tribunal de Contas da União no âmbito do programa permanente de auditorias em obras e serviços de engenharia Fiscobras, desde 2011, ano em que foi instituído o regime de contratação integrada até 2014 foram focadas no tema gerenciamento de riscos.

\subsection{DELIMITAÇÃO DO TEMA}

Preliminarmente, destaca-se que o instituto da contratação integrada não constitui propriamente uma inovação em nosso ordenamento jurídico, pois o Decreto $\mathrm{n}^{\circ} 2.745$, de 24/8/1998, o qual aprova o Regulamento do Procedimento Licitatório Simplificado da PETROBRAS previsto no art. 67 da Lei $n^{\circ}$ 9.478, de 6/8/1997, também prevê a possibilidade de contratação integrada em seu item 1.9, in verbis:

\subsection{Sempre que economicamente recomendável, a PETROBRAS poderá utilizar-se da contratação integrada, compreendendo realização de projeto básico elou detalhamento, realização de obras e serviços, montagem, execução de testes, pré- operação e todas as demais operações necessárias e suficientes para a entrega final do objeto, com a solidez e segurança especificadas.}

Nesse tipo de contratação, a Administração consegue programar melhor o valor do 
investimento, haja vista a transferência de riscos de projeto, aquisição, construção e performance ao contratado. Contudo, a Administração assume o risco de o orçamento do empreendimento por ela projetado, bem como da contratação estarem superestimados, uma vez que as contingências a serem consideradas pela empresa executora do projeto tendem a ser altas.

Em que pese o registro que cabe à PETROBRAS, destaca-se que este trabalho não abrange em seu escopo os investimentos capitaneados pela referida empresa, tendo em vista a especificidade das tipologias de suas principais obras, uma vez que se tratam de empreendimentos industriais, somado ao fato de que os orçamentos elaborados pela Petrobras são considerados pela empresa como peças sigilosas sob alegação de constituírem segredo comercial da companhia sensíveis à sua estratégia corporativa.

Ademais, este trabalho cingisse nas obras executadas sob o regime de contratação integrada estabelecido conforme art. $9^{\circ}$ da Lei $n^{\circ} 12.462 / 2011$, visto que os demais regimes previstos, a saber: empreitada por preço unitário, empreitada por preço global, contratação por tarefa e empreitada integral, são os mesmos esposados na Lei n 8.666/93.

Embora também demandem compartilhamento do risco entre público e privado, os seguintes arranjos econômicos e financeiros de participação privada na realização dos investimentos para a implantação dos empreendimentos não são objeto desse trabalho: i) obras afetas a contratos de concessão delineadas pelas Leis $\mathrm{n}^{\circ} 8.987 / 1995$ e $\mathrm{n}^{\circ}$ 9.074/1995, e ii) obras fruto de Parcerias Público-Privadas (PPPs) tratadas na Lei $\mathrm{n}^{\circ}$ $11.079 / 2004$.

Nesses outros casos, a modelagem envolve não apenas os riscos da construção do empreendimento, mas também àqueles afetos a sua operação e manutenção por longo prazo.

Todos os certames considerados foram àqueles homologados na modalidade de contratação integrada até 2014 por órgãos e/ou entidades vinculados ao poder executivo federal sediados em Brasília.

Pelas características das ampliações do RDC, os certames analisados envolveram predominantemente obras de infraestrutura rodoviárias e em seguida obras ferroviárias.

Outra limitação do tema reside no fato de que o DNIT não disponibiliza a documentação 
de análise de risco de cada licitação em sua página oficial na internet, mesmo quando da adjudicação do objeto ou quando da revogação do certame, conforme o caso.

Ademais, também não foram realizadas análises do estágio de execução das obras, visto que nenhum órgão disponibiliza as informações sobre o andamento dos empreendimentos que realiza, sendo que as mesmas são necessárias para qualquer tipo de avaliação que se pretenda realizar.

Por fim, cabe destacar que não é objeto desse trabalho perscrutar qual o alcance da fiscalização e da gestão contratual efetuadas pela contratante, visto que a modalidade contratação integrada segue a mesma lógica da empreitada por preço global e a empreitada integral, isto é, medição dos serviços por preço certo e total, fundamentalmente após a execução de cada etapa previamente definida no cronograma físico-financeiro.

\subsection{ESTRUTURA DO TRABALHO}

Esta pesquisa está estruturada em 5 capítulos, incluindo essa introdução (Capítulo 1), onde é apresentada a justificativa, delimitação do tema e objetivos geral e específicos do trabalho.

No Capítulo 2 apresenta-se a revisão bibliográfica, com os subsídios teóricos a respeito dos principais elementos relacionados com a temática pesquisada. Este capítulo inicia-se com a contextualização acerca dos modelos de gerenciamento de projetos e riscos. Em sequência apresenta o arcabouço legal e jurisprudencial brasileiro, sistematizando a legislação, os normativos e os contornos das principais deliberações do Tribunal de Contas da União. Por fim, aborda as práticas internacionais para contratação e avaliação de contingências.

O Capítulo 3 apresenta e detalha a correlação entre as 5 etapas do método de pesquisa empregado, a saber: Levantamentos, Fórum de Debates sobre Riscos em Obras Públicas, Matrizes de Avaliação no Nível de Maturidade, Análises e Diretrizes.

O Capítulo 4 apresenta e discute os resultados das avaliações estruturados de acordo com as etapas do método de pesquisa empregado. A análise crítica efetuada é pautada em aspectos orientativos-preventivos, de modo que a explicitação das inconsistências 
observadas possa adequadamente retroalimentar o planejamento de futuras licitações efetuadas na contratação integrada.

As conclusões obtidas com as respostas aos objetivos gerais e específicos do trabalho encontram-se no Capítulo 5. Nesse capítulo ainda são propostas novas pesquisas sobre o tema.

Ao fim das conclusões expostas no Capítulo 5, são apresentadas as referências bibliográficas consultadas neste trabalho, o Glossário e os Apêndices. 


\section{REVISÃO BIBLIOGRÁFICA}

O propósito deste capítulo é oferecer subsídios teóricos a respeito dos principais elementos relacionados com a temática pesquisada: os principais modelos referenciais de gerenciamento de projetos e riscos, o arcabouço legal e jurisprudencial brasileiro para obras públicas e as práticas internacionais para contratação e avaliação de contingências.

\subsection{MODELOS DE GERENCIAMENTO DE PROJETOS E RISCOS}

De acordo com Jugend et al (2014) o tema gerenciamento de projetos é presença constante na pauta diária das organizações haja vista que as atuais demandas exigem a condução simultânea de diferentes projetos dentro de prazos restritos estabelecidos e com qualidade e orçamentos rigorosos. Sobre o tema, os fundamentos trazidos do Guia PMBOK (2013), Project Management Body of Knowledge do Project Management Institute (PMI) tornaram-se padrão global em gerenciamento de projetos.

Além disso, a recente alteração legislativa proveniente da instituição da Lei $\mathrm{n}^{\circ} 12.462$, de 4/8/2011, tem exposto cada vez mais a necessidade da completa compreensão dos modelos de gerenciamento de projetos, em especial os riscos de projetos, uma vez que os mesmos emergem como elemento central nesse novo panorama de obras públicas em que se busca uma melhor distribuição das obrigações entre os agentes envolvidos, de modo a se definir os responsáveis perante os riscos e a sua minimização relativa aos aspectos de escopo, cronograma, custo e qualidade.

Nesse sentido, uma obra pública pode ser considerada, em sentido amplo, nos termos do Guia PMBOK (2013), como um "projeto", pois representa um esforço temporário definido, em que o seu término compreende a conclusão e entrega do empreendimento conforme as condições estabelecidas pela administração pública contratante.

Conforme o Guia PMBOK (2013), o gerenciamento de um projeto se caracteriza pela aplicação de conhecimentos, habilidades, ferramentas e técnicas às atividades do projeto a fim de cumprir os seus requisitos.

O gerenciamento de projetos tipicamente inclui a aplicação e integração apropriadas de 10 áreas de conhecimento específicas. Uma área de conhecimento representa um conjunto completo de conceitos, termos e atividades que compõem um campo profissional, campo 
de gerenciamento de projetos, ou uma área de especialização. As áreas de conhecimento são:

- Gerenciamento da integração do projeto;

- Gerenciamento do escopo do projeto;

- Gerenciamento do tempo do projeto;

- Gerenciamento dos custos do projeto;

- Gerenciamento da qualidade do projeto;

- Gerenciamento dos recursos humanos do projeto;

- Gerenciamento das comunicações do projeto;

- Gerenciamento dos riscos do projeto;

- Gerenciamento das aquisições do projeto; e

- Gerenciamento das partes interessadas do projeto

As áreas de conhecimento englobam 47 processos de gerenciamento de projetos, logicamente agrupados em cinco grupos de processos, conforme a seguir descrito:

- Grupo de processos de iniciação. Consiste dos processos executados para definir um novo projeto ou uma nova fase de um projeto existente através da obtenção de autorização para iniciar o projeto ou fase;

- Grupo de processos de planejamento. Consiste dos processos necessários para definir o escopo do projeto, refinar os objetivos e definir a linha de ação necessária para alcançar os objetivos para os quais o projeto foi criado;

- Grupo de processos de execução. Consiste dos processos realizados para executar o trabalho definido no plano de gerenciamento do projeto para satisfazer as especificações do projeto;

- Grupo de processos de monitoramento e controle. Consiste dos processos exigidos para acompanhar, analisar e controlar o progresso e desempenho do projeto, identificar 
quaisquer áreas nas quais serão necessárias mudanças no plano, e iniciar as mudanças correspondentes; e

- Grupo de processos de encerramento. Consiste dos processos executados para finalizar todas as atividades de todos os grupos de processos, visando encerrar formalmente o projeto ou fase.

Os Quadros 2.1 e 2.2, a seguir, representam o agrupamento dos 47 processos de gerenciamento de projetos por grupos de processos e por área de conhecimento.

Importa destacar que estes cinco grupos de processos têm dependências claras e em geral são executados em qualquer projeto e possuem um alto grau de interação entre si. A natureza dessas interações varia de um projeto para outro e não está retratada nos referidos quadros.

\begin{tabular}{|c|c|c|c|c|c|}
\hline \multirow[b]{2}{*}{$\begin{array}{c}\text { Áreas de } \\
\text { conhecimento }\end{array}$} & \multicolumn{5}{|c|}{ Grupos de processos de gerenciamento de projetos } \\
\hline & $\begin{array}{l}\text { Grupo de } \\
\text { processos de } \\
\text { iniciação }\end{array}$ & $\begin{array}{l}\text { Grupo de processos de } \\
\text { planejamento }\end{array}$ & $\begin{array}{c}\text { Grupo de } \\
\text { processos de } \\
\text { execução }\end{array}$ & $\begin{array}{c}\text { Grupo de } \\
\text { processos de } \\
\text { monitoramento } \\
\text { e controle } \\
\end{array}$ & $\begin{array}{c}\text { Grupo de } \\
\text { processos de } \\
\text { encerramento }\end{array}$ \\
\hline $\begin{array}{l}\text { 1. Gerenciamento } \\
\text { da integração do } \\
\text { projeto }\end{array}$ & 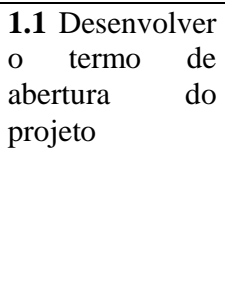 & $\begin{array}{l}\text { 1.2 Desenvolver o plano } \\
\text { de gerenciamento do } \\
\text { projeto }\end{array}$ & $\begin{array}{ll}\mathbf{1 . 3} \text { Orientar } & \mathrm{e} \\
\text { gerenciar } & \mathrm{o} \\
\text { trabalho } & \text { do } \\
\text { projeto } & \end{array}$ & $\begin{array}{ll}\text { 1.4 Monitorar e } \\
\text { controlar o } \\
\text { trabalho do } \\
\text { projeto } \\
\text { 1.5 Realizar o } \\
\text { controle } & \\
\text { integrado de } \\
\text { mudanças }\end{array}$ & $\begin{array}{l}\text { 1.6 Encerrar o } \\
\text { projeto ou fase }\end{array}$ \\
\hline $\begin{array}{l}\text { 2. Gerenciamento } \\
\text { do escopo do } \\
\text { projeto }\end{array}$ & & $\begin{array}{l}\text { 2.1 Planejar o } \\
\text { gerenciamento do escopo } \\
\text { 2.2 Coletar os requisitos } \\
\text { 2.3 Definir o escopo } \\
\text { 2.4 Criar a estrutura } \\
\text { analítica do projeto (EAP) }\end{array}$ & & $\begin{array}{l}\text { 2.5 Validar o } \\
\text { escopo } \\
\text { 2.6 Controlar o } \\
\text { escopo }\end{array}$ & \\
\hline $\begin{array}{l}\text { 3. Gerenciamento } \\
\text { do tempo do projeto }\end{array}$ & & $\begin{array}{l}\text { 3.1 Planejar o } \\
\text { gerenciamento do } \\
\text { cronograma } \\
\text { 3.2 Definir as atividades } \\
\text { 3.3 Sequenciar as } \\
\text { atividades } \\
\text { 3.4 Estimar os recursos } \\
\text { das atividades } \\
\text { 3.5 Estimar as durações } \\
\text { das atividades } \\
\text { 3.6 Desenvolver o } \\
\text { cronograma }\end{array}$ & & $\begin{array}{l}3.7 \text { Controlar o } \\
\text { cronograma }\end{array}$ & \\
\hline $\begin{array}{l}\text { 4. Gerenciamento } \\
\text { dos custos do } \\
\text { projeto }\end{array}$ & & $\begin{array}{l}\text { 4.1 Planejar o } \\
\text { gerenciamento dos custos } \\
\text { 4.2 Estimar os custos } \\
\text { 4.3 Determinar o } \\
\text { orçamento }\end{array}$ & & $\begin{array}{l}\text { 4.4 Controlar os } \\
\text { custos }\end{array}$ & \\
\hline
\end{tabular}

Quadro 2.1 - Processos de gerenciamento de projetos - áreas 1 a 4 Fonte: Adaptado do Guia PMBOK (2013) 


\begin{tabular}{|c|c|c|c|c|c|}
\hline \multirow[b]{2}{*}{$\begin{array}{c}\text { Áreas de } \\
\text { conhecimento }\end{array}$} & \multicolumn{5}{|c|}{ Grupos de processos de gerenciamento de projetos } \\
\hline & $\begin{array}{l}\text { Grupo de } \\
\text { processos de } \\
\text { iniciação }\end{array}$ & $\begin{array}{l}\text { Grupo de processos de } \\
\text { planejamento }\end{array}$ & $\begin{array}{l}\text { Grupo de } \\
\text { processos de } \\
\text { execução }\end{array}$ & $\begin{array}{c}\text { Grupo de } \\
\text { processos de } \\
\text { monitoramento } \\
\text { e controle }\end{array}$ & $\begin{array}{c}\text { Grupo de } \\
\text { processos de } \\
\text { encerramento }\end{array}$ \\
\hline $\begin{array}{l}\text { 5. Gerenciamento } \\
\text { da qualidade do } \\
\text { projeto }\end{array}$ & & $\begin{array}{lr}\mathbf{5 . 1} \quad \text { Planejar } & \text { o } \\
\text { gerenciamento } & \text { da } \\
\text { qualidade } & \\
\end{array}$ & $\begin{array}{lr}5.2 \quad \text { Realizar } & \text { a } \\
\text { garantia } & \text { da } \\
\text { qualidade } & \\
\end{array}$ & $\begin{array}{l}5.3 \text { Controlar a } \\
\text { qualidade }\end{array}$ & \\
\hline $\begin{array}{l}\text { 6. Gerenciamento } \\
\text { dos recursos } \\
\text { humanos do projeto }\end{array}$ & & $\begin{array}{lr}\mathbf{6 . 1} & \text { Planejar } \\
\text { gerenciamento } & \text { dos } \\
\text { recursos humanos } & \end{array}$ & $\begin{array}{l}\text { 6.2 Mobilizar a } \\
\text { equipe do projeto } \\
\text { 6.3 Desenvolver a } \\
\text { equipe do projeto } \\
\text { 6.4 Gerenciar a } \\
\text { equipe do projeto }\end{array}$ & & \\
\hline $\begin{array}{l}\text { 7. Gerenciamento } \\
\text { das comunicações } \\
\text { do projeto }\end{array}$ & & $\begin{array}{l}\text { 7.1 Planejar } \\
\text { gerenciamento } \\
\text { comunicações }\end{array}$ & $\begin{array}{l}\text { 7.2 Gerenciar as } \\
\text { comunicações }\end{array}$ & $\begin{array}{l}\text { 7.3 Controlar as } \\
\text { comunicações }\end{array}$ & \\
\hline $\begin{array}{l}\text { 8. Gerenciamento } \\
\text { dos riscos do } \\
\text { projeto }\end{array}$ & & $\begin{array}{l}\text { 8.1 Planejar } \\
\text { gerenciamento dos riscos } \\
\text { 8.2 Identificar os riscos } \\
\text { 8.3 Realizar a análise } \\
\text { qualitativa dos riscos } \\
\text { 8.4 Realizar a análise } \\
\text { quantitativa dos riscos } \\
\text { 8.5 Planejar as respostas } \\
\text { aos riscos }\end{array}$ & & $\begin{array}{l}\text { 8.6 Controlar os } \\
\text { riscos }\end{array}$ & \\
\hline $\begin{array}{l}\text { 9. Gerenciamento } \\
\text { das aquisições do } \\
\text { projeto }\end{array}$ & & $\begin{array}{lr}9.1 \quad \text { Planejar } & \text { o } \\
\text { gerenciamento } & \text { das } \\
\text { aquisições } & \\
\end{array}$ & $\begin{array}{l}9.2 \text { Conduzir as } \\
\text { aquisições }\end{array}$ & $\begin{array}{l}\text { 9.3 Controlar as } \\
\text { aquisições }\end{array}$ & $\begin{array}{l}\text { 9.4 Encerrar as } \\
\text { aquisições }\end{array}$ \\
\hline $\begin{array}{l}\text { 10. Gerenciamento } \\
\text { das partes } \\
\text { interessadas do } \\
\text { projeto }\end{array}$ & $\begin{array}{lr}\mathbf{1 0 . 1} & \text { Identificar } \\
\text { as } & \text { partes } \\
\text { interessadas }\end{array}$ & $\begin{array}{l}\text { 10.2 Planejar } \\
\text { gerenciamento das partes } \\
\text { interessadas }\end{array}$ & $\begin{array}{l}\text { 10.3 Gerenciar o } \\
\text { engajamento das } \\
\text { partes } \\
\text { interessadas }\end{array}$ & $\begin{array}{l}\text { 10.4 Controlar o } \\
\text { engajamento } \\
\text { das partes } \\
\text { interessadas }\end{array}$ & \\
\hline
\end{tabular}

Quadro 2.2 - Processos de gerenciamento de projetos - áreas 5 a 10

Fonte: Adaptado do Guia PMBOK (2013)

Do Quadro 2.2 é possível observar que os processos que compõem o gerenciamento dos riscos do projeto (item 8) são essencialmente processos de planejamento. Um fator chave de sucesso que deve estar presente é considerar o gerenciamento dos riscos como uma importante contribuição para o sucesso do projeto.

Um dos principais produtos desse conjunto de processos é o plano de gerenciamento de riscos, sendo essencial que o mesmo deva começar quando o projeto é concebido, e ser concluído na fase inicial do planejamento do projeto. O plano de gerenciamento dos riscos é um componente do plano de gerenciamento do projeto, e descreve como as atividades de gerenciamento dos riscos serão estruturadas e executadas.

Para fins de registro, os seis processos de gerenciamento de risco preconizados no Guia PMBOK (2013) são a seguir sinteticamente apresentados: 
i. Planejar o gerenciamento dos riscos - O processo de definição de como conduzir as atividades de gerenciamento dos riscos de um projeto;

ii. Identificar os riscos - O processo de determinação dos riscos que podem afetar o projeto e de documentação das suas características;

iii. Realizar a análise qualitativa dos riscos - O processo de priorização de riscos para análise ou ação posterior através da avaliação e combinação de sua probabilidade de ocorrência e impacto;

iv. Realizar a análise quantitativa dos riscos - O processo de analisar numericamente o efeito dos riscos identificados nos objetivos gerais do projeto;

v. Planejar as respostas aos riscos - O processo de desenvolvimento de opções e ações para aumentar as oportunidades e reduzir as ameaças aos objetivos do projeto; e

vi. Controlar os riscos - O processo de implementar planos de respostas aos riscos, acompanhar os riscos identificados, monitorar riscos residuais, identificar novos riscos e avaliar a eficácia do processo de gerenciamento dos riscos durante todo o projeto.

Em termos de fluxo, esses processos podem ser compreendidos como uma sequência executiva ordenada e iterativa de fases (i, ii, iii, iv, v e vi), representada por um ciclo.

Nesse ciclo cabe à fase de controle dos riscos (processo vi), o monitoramento e avaliação da eficácia do processo com vistas a retroalimentação de todo o planejamento.

Complementarmente ao Guia PMBOK (2013), cabe destacar que os modelos de gerenciamento de risco do PRINCE2 (2009) e dos normativos da International Organization for Standardization - ISO seguem uma metodologia semelhante, conforme demonstrado no Quadro 2.2, a seguir.

Ademais, registra-se que os normativos da ISO foram adotados no Brasil de forma idêntica, em conteúdo técnico, estrutura e redação, pela Associação Brasileira de Normas Técnicas - ABNT, por meio das seguintes normas técnicas: a) ABNT NBR ISO 31.000 (2009); b) ABNT NBR ISO/IEC 31.010 (2012); e c) ABNT NBR ISO 21500 (2012). 


\begin{tabular}{|c|l|}
\hline Modelo de gerenciamento de riscos & \multicolumn{1}{|c|}{ Processos de gerenciamento de riscos } \\
\hline Guia PMBOK & $\begin{array}{l}\text { Planejar o gerenciamento dos riscos } \\
\text { Identificar os riscos } \\
\text { Realizar a análise qualitativa dos riscos } \\
\text { Realizar a análise quantitativa dos riscos } \\
\text { Planejar as respostas aos riscos } \\
\text { Controlar os riscos }\end{array}$ \\
\hline PRINCE2 & $\begin{array}{l}\text { Identificar } \\
\text { Avaliação } \\
\text { Planejar } \\
\text { Implementar } \\
\text { Comunicar }\end{array}$ \\
\hline ABNT ISO & $\begin{array}{l}\text { Estabelecimento do Contexto } \\
\text { Processo de Avaliação de Riscos } \\
\text { Tratamento de Riscos } \\
\text { Monitoramento e Análise Crítica } \\
\text { Comunicação e Consulta }\end{array}$ \\
\hline
\end{tabular}

Quadro 2.3 - Processos de gerenciamento de riscos por modelo Fonte: Adaptado de Fortes (2011).

Conforme PRINCE2 (2009), os quatro primeiros passos são sequenciais, já o passo "Comunicar" corre em paralelo, porque os resultados de qualquer dos outros passos podem ter que ser comunicados antes da conclusão do processo global. Todos os passos são iterativos e quando uma informação adicional se torna disponível é muitas vezes necessário revisitar as etapas anteriores e realizá-los novamente para conseguir o resultado mais eficaz.

Nesse contexto, para que o processo de gerenciamento de riscos em projetos seja eficaz, é importante que ele seja cíclico e dinâmico. Convém que as etapas do processo de gerenciamento de riscos em projetos sejam periodicamente analisadas criticamente ao longo do ciclo de vida do projeto, considerando a própria natureza dinâmica na qual os projetos estão inseridos. 
Especificamente em relação ao conceito de risco, ainda considerando o Guia PMBOK (2013), o risco do projeto tem origem na incerteza existente em todos os projetos, sendo o mesmo um evento ou condição incerta que, se ocorrer, provocará um efeito positivo ou negativo em um ou mais parâmetros do projeto tais como escopo, cronograma, custo e qualidade. Os riscos positivos e negativos são comumente chamados de oportunidades e ameaças.

A outro giro, Neto (2009) afirma que risco é a mensuração objetiva da incerteza em relação a eventos desfavoráveis, sendo a incerteza entendida como uma possibilidade de ocorrerem resultados diferentes daqueles inicialmente previstos. Assim, por mais que a equipe de elaboração do projeto saiba que o empreendimento enfrentará incertezas, estas podem ser apenas expectativas subjetivas.

Portanto, segundo Neto (2009), uma situação de incerteza transforma-se em uma situação de risco quando a incerteza é mensurada através de uma medida objetiva. Assim, quando os resultados desfavoráveis ou negativos são apenas possibilidades, sem qualquer medida clara e objetiva ou probabilidade de ocorrência, não se tem uma situação denominada arriscada.

Nesse ponto, importa destacar que a definição do preço a ser ofertado por uma empresa licitante será proporcional aos riscos envolvidos e por quem eles serão assumidos. Portanto, a clareza da distribuição de responsabilidades entre as partes contratante e contratada é imprescindível para a adequada formulação dos orçamentos constituintes dos certames, dado que a alocação imprópria de riscos encarece o custo final de implantação dos projetos.

Como será posteriormente detalhado, a premissa que fundamenta as recentes alterações legislativas pra contratação de obras públicas, notadamente a contratação integrada, é atribuir maior responsabilidade ao contratado e como consequência diminuir os riscos assumidos pelo contratante, ou seja, a Administração Pública, uma vez que os aditivos nesse tipo de contratação são expressamente vedados.

Assim, o planejamento de respostas perante o risco é fundamental, uma vez que há diversas estratégias que podem ser adotadas a depender do tipo de risco envolvendo, conforme demonstrado no Quadro 2.3. 


\begin{tabular}{|c|c|}
\hline Riscos negativos ou ameaças & Riscos positivos ou oportunidade \\
\hline Prevenir & Explorar \\
\hline Transferir & Melhorar \\
\hline Mitigar & Compartilhar \\
\hline \multicolumn{2}{|c|}{ Aceitar (aceitação passiva) } \\
\hline \multicolumn{2}{|c|}{ Aceitar (aceitação ativa) } \\
\hline
\end{tabular}

Quadro 2.4 - Estratégias de resposta perante o risco

Fonte: Autor.

Com vista a evitar os altos custos associados a esse cenário, Marcondes (2014) destaca o principio da alocação técnica de riscos, em que os riscos devem ser alocados àquelas partes mais capacitadas para avaliá-los, gerenciá-los e suportar os custos e benefícios dessa assunção. Assim, muitos dos riscos ficam mais bem alocados quando divididos, e cada risco tem um custo associado que precisará ser assumido por alguém em algum certo estágio do processo.

Neto (2009) complementa que caso não haja dados históricos ou os disponíveis não sejam representativos do comportamento futuro, ou seja, do valor esperado, o valor do ativo pode ser dado por expectativas subjetivas sobre os comportamentos futuros dos fatores de risco identificados.

Assim, para a definição do valor e cronograma de referência para um certame de uma obra pública ou do valor de uma proposta de um licitante, tanto a Administração quanto os potenciais contratados devem incluir provisões nas linhas de base de seus custos e de seus cronogramas para riscos conhecidos para os quais respostas contingentes ou mitigadoras estão estabelecidas.

Linha de base é a versão aprovada de um produto de trabalho que só pode ser alterada através de procedimentos formais de controle de mudança e é usada como uma base de comparação entre os resultados planejados versus os resultados realmente executados. Há quatro tipos de linhas de base: i) custos, ii) cronograma, iii) escopo e iv) medição de desempenho e as mesmas compõem o plano de gerenciamento do projeto (Guia PMBOK, 2013). 
Os riscos conhecidos (denominados "known unknowns") são aqueles que foram identificados e analisados, possibilitando o planejamento de respostas. Assim, a reserva de contingência é um valor que aborda os riscos conhecidos, de custo e cronograma, que não podem ser gerenciados de forma proativa (Guia PMBOK, 2013).

A reserva de contingência pode ser uma percentagem do custo estimado ou da duração estimada da atividade, conforme o caso, um número fixado ou pode ser desenvolvida através do uso de métodos de análise quantitativa, como por exemplo, a simulação de Monte Carlo (Guia PMBOK, 2013).

À medida que informações mais precisas sobre o projeto são disponibilizadas, a reserva de contingência pode ser usada, reduzida ou eliminada. A contingência deve ser claramente identificada na documentação dos custos e do cronograma. As reservas de contingência são parte dos requisitos das linhas de bases de custo e cronograma e dos requisitos gerais de custo e cronograma do projeto.

Em que pese a possibilidade de estimação da reserva de contingência para cada empreendimento em decorrência de um cenário de risco definido, o Departamento de Transporte da Califórnia - Caltrans (2009) estabelece por meio da diretiva PD-04 Project Contingencies and Supplemental Work, para as obras rodoviárias naquele estado o padrão de contingência em 5\% da estimativa final de custo, sendo que um aumento desse valor deve ser tecnicamente justificado, estando o mesmo limitado a $10 \%$ deste custo.

Importa destacar que a versão de 2014 do capítulo 20 do Manual Eletrônico de Procedimentos de Desenvolvimento de Projetos do Departamento de Transporte da Califórnia, Caltrans (2014) utiliza percentuais referenciais de contingência para cada fase de desenvolvimento do orçamento, conforme verificado no Quadro 2.4. 


\begin{tabular}{|l|l|c|}
\hline \multicolumn{1}{|c|}{ Marcos de controle } & $\begin{array}{c}\text { Percentual } \\
\text { de } \\
\text { contingência }\end{array}$ \\
\hline \multicolumn{1}{|c|}{ Tradução ajustada } & Termo em inglês & \\
\hline 1. Fase de Estudo & Project Planning Cost Estimates & $30 \%$ a $50 \%$ \\
\hline 1.2. Estimatimativa de custo & Project Study Report Cost Estimate & $25 \%$ \\
\cline { 2 - 3 } & Draft Project Report Cost Estimate & $20 \%$ \\
\hline 1.3. Orçamento preliminar & Project Report Cost Estimate & $15 \%$ \\
\hline 2. Fase de Projeto & Project Design Cost Estimates & \\
\hline 2.1. Orçamento detalhado ou analítico & Preliminary Engineer's Cost Estimate & $10 \%$ \\
\hline
\end{tabular}

Quadro 2.5 - Escala de contingência por fase de desenvolvimento do orçamento Fonte: Adaptado do Capítulo 20 de Caltrans (2014)

Em razão da possibilidade de desconexão da tradução literal dos termos em inglês para o português, foram realizados, para fins de melhor entendimento técnico, ajustes terminológicos visando adequá-los às particularidades da prática da engenharia brasileira. Assim, os marcos de controle no Quadro 2.4 são apresentados de duas formas, a primeira considerada tradução ajustada e a segunda, o termo propriamente na língua inglesa.

Nesse contexto, importa destacar que Relatório do Departamento de Transportes Americano, USDOT (2015) concluído em fevereiro de 2015, referente a uma ampla pesquisa de âmbito nacional nos 51 Departamentos Estaduais de Transporte nos Estados Unidos sobre as práticas de estimação de custos, concluiu que aproximadamente $70 \%$ dos Departamentos Estaduais de Transporte Americano não utilizam uma abordagem baseada no risco para desenvolver estimativas de custos.

Cumpre observar que este relatório decorreu do cumprimento de recomendações provenientes de dois trabalhos de órgãos de controle americano: i) Relatório GAO-09-751 de 2009 do Government Accountability Office (GAO), entidade americana de controle 
externo equivalente ao Tribunal de Contas da União no Brasil e ii) Relatório MH-2013-012 de 2012 do U.S. Department of Transportation Office of Inspector General (OIG), entidade americana de controle interno.

Cabe destacar também que há outro tipo de provisão denominada reserva de gerenciamento (ou reserva gerencial) que é utilizada para os riscos desconhecidos (denominados "unknown unknowns") de custo e cronograma, uma vez que os mesmos não podem ser gerenciados de forma proativa.

A reserva de gerenciamento é uma quantidade especificada do custo ou da duração do projeto, conforme o caso, retida para fins de controle de gerenciamento durante a fase de execução do empreendimento e reservada para o trabalho imprevisto que está dentro do escopo do projeto.

A reserva de gerenciamento não está incluída na linha de base dos custos nem na linha de base do cronograma, assim não é um fator de análise da administração contratante ao elaborar orçamento e o cronograma de referência para um certame ou para medir o desempenho do contratado.

A reserva de gerenciamento faz parte apenas dos requisitos gerais de custo e de duração de todo o projeto e devem somente ser levados em consideração quando de um imprevisto na fase de execução do empreendimento.

À título exemplificativo a situação que melhor ilustra a utilização da reserva de gerenciamento ocorre quando o contratado dispõe desse valor alocado para honrar compromissos em função da demora no pagamento das faturas efetuado pela administração, seja em virtude de atraso propriamente dito ou seja em função do próprio rito burocrático.

Por fim, destaca-se que os principais conceitos explorados sobre gerenciamento de projetos e gerenciamento de riscos encontram-se no glossário desta dissertação. 


\subsection{ARCABOUÇO LEGAL E JURISPRUDENCIAL BRASILEIRO}

Em relação ao arcabouço legal brasileiro, este trabalho sistematiza a legislação, os normativos e os contornos das principais deliberações exaradas pelo Tribunal de Contas da União sobre a matéria.

Senna (2014) distingue as obras conforme as possibilidades de financiamento privado dentro de um contexto de capacidade de geração receita do empreendimento, variando desde uma participação totalmente pública, até uma totalmente privada, passando por uma variedade de arranjos entre esses dois extremos.

Com referência neste autor, há um pequeno grupo de projetos de investimento considerados auto-sustentáveis, caracterizados pela alta capacidade de geração de receita. São as chamadas concessões, suportadas pelas Leis $\mathrm{n}^{\circ} 8.987 / 1995$ e $\mathrm{n}^{\circ} 9.074 / 1995$, onde o financiamento é totalmente privado.

No intermédio, há um grupo de projetos considerados parcialmente sustentados com contraprestação pecuniária do parceiro público ao parceiro privado, em um arranjo denominado Parceria-Público-Privada (PPP), instituído pela Lei n 11.079/2004.

$\mathrm{Na}$ outra ponta, a maior parte dos financiamentos para investimentos em infraestrutura vem dos orçamentos públicos, pois tais projetos não tem capacidade de geração de receita advindas de sua exploração capazes de atrair o capital privado. São as obras públicas em sentido estrito, que até a instituição do Regime Diferenciado de Contratações (RDC), Lei $\mathrm{n}^{\circ} 12.462 / 2011$, eram somente disciplinadas pela Lei $\mathrm{n}^{\circ} 8.666 / 1993$.

A Figura 2.1, adaptada de Portugal (2008) apud Senna (2014), apresenta as possiblidades de arranjos econômicos e financeiros, considerando a base legal que dá suporte às várias formas de financiamento. 


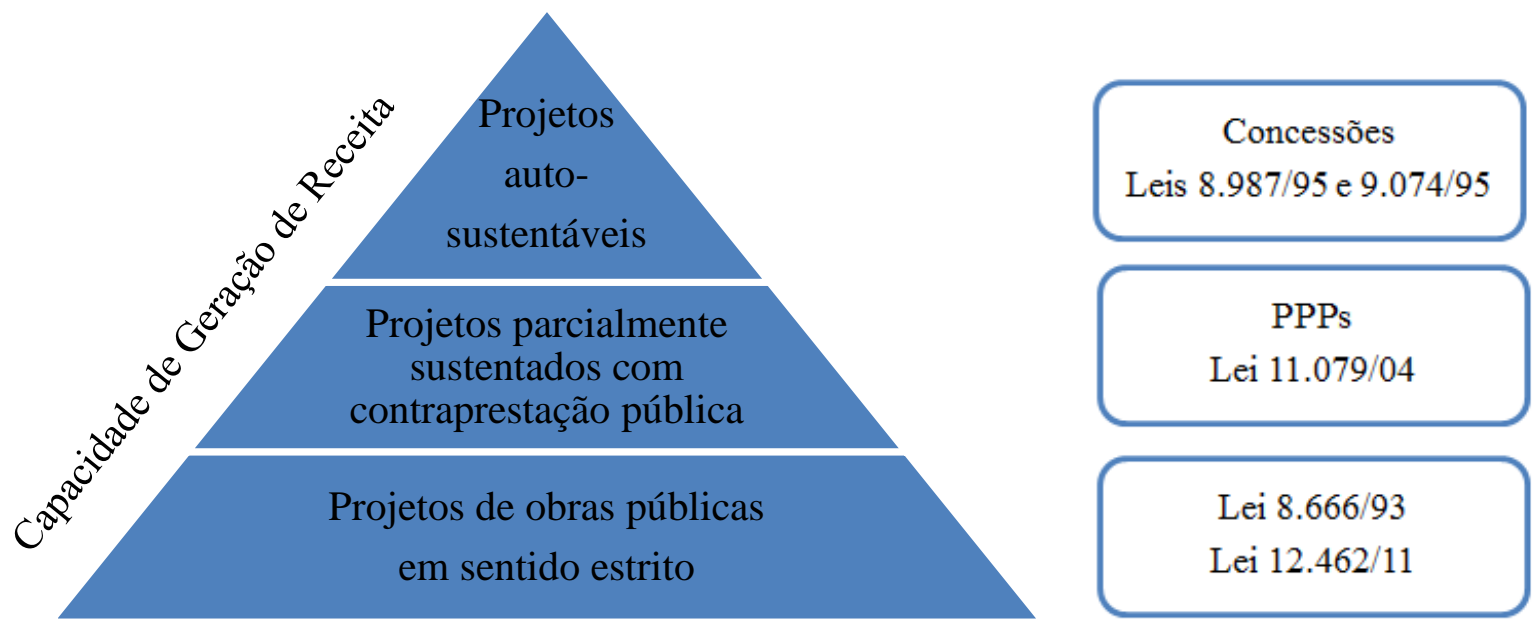

Figura 2.1 - Base Legal de suporte para as várias possibilidades de financiamento. Fonte: Adaptada de Portugal (2008) apud Senna (2014)

Rezende (2011) qualifica que a Lei $\mathrm{n}^{\circ}$ 8.666, de 1993, que instituiu normas gerais para licitações e contratos administrativos, é frequentemente criticada sob o argumento de que, com seu grande número de prescrições burocráticas, ela seria incapaz de assegurar rapidez ao processo licitatório, além de não garantir condições vantajosas para a Administração Pública nos contratos que celebra.

Nessa esteira, arguindo urgência no estabelecimento de novas regras para as licitações e contratos necessários à construção de infraestruturas para a Copa do Mundo de 2014 e para as Olimpíadas de 2016, o Congresso Nacional aprovou a Lei $\mathrm{n}^{\circ} 12.462$, de 2011, que cria o Regime Diferenciado de Contratações Públicas (RDC).

Posteriormente, foi editado o Decreto Federal $n^{\circ}$ 7.581, em 11/10/2011, que, ao longo de seus 114 artigos, disciplinou todo o procedimento licitatório no âmbito do RDC, e que já foi objeto de duas revisões, por intermédio do Decreto ${ }^{\circ}$ 8.080, de 20/8/2013 e Decreto $\mathrm{n}^{\circ}$ 8.251 , de 23/5/2014.

Contudo, salienta-se que o referido regime inicialmente limitado aos eventos desportivos, foi sucessivamente ampliado para nove outros tipos de empreendimentos, conforme a seguir discriminado em ordem cronológica:

i. Lei $\mathrm{n}^{\circ} 12.688$, de 18/7/2012 - ações integrantes do Programa de Aceleração do Crescimento - PAC; 
ii. Lei $\mathrm{n}^{\circ} 12.722$, de 3/10/2012 - obras e serviços de engenharia no âmbito dos sistemas públicos de ensino;

iii. Lei $\mathrm{n}^{\circ} 12.745$, de 19/12/2012 - obras e serviços de engenharia no âmbito do Sistema Único de Saúde - SUS;

iv. Lei $\mathrm{n}^{\circ} 12.815$, de 5/6/2013 - contratações das obras e serviços no âmbito do Programa Nacional de Dragagem Portuária e Hidroviária II - PDN II;

v. Lei $n^{\circ} 12.833$, de 20/6/2013 - aquisição de bens, contratação de obras e serviços de engenharia e de técnicos especializados quando oriundos de recursos do Fundo Nacional de Aviação Civil - FNAC e destinados à modernização, construção, ampliação ou reforma de aeródromos públicos;

vi. Lei $n^{\circ} 12.865$, de 9/10/2013 - obras e serviços de engenharia relacionados ao desenvolvimento de projetos, modernização, ampliação, construção ou reforma da rede integrada e especializada para atendimento da mulher em situação de violência, por intermédio da Secretaria de Políticas para as Mulheres da Presidência da República - SPM/PR;

vii. Lei $\mathrm{n}^{\circ} 12.873$, de 24/10/2013 - contratação de todas as ações relacionadas à reforma, modernização, ampliação ou construção de unidades armazenadoras próprias destinadas às atividades de guarda e conservação de produtos agropecuários em ambiente natural, pela Companhia Nacional de Abastecimento CONAB; e

viii. Lei $\mathrm{n}^{\circ} 12.980$, de 28/5/2014 - obras e serviços de engenharia para construção, ampliação e reforma de estabelecimentos penais e unidades de atendimento socioeducativo.

ix. Lei $n^{\circ} 12.983$, de 2/6/2014 - as licitações e aos contratos destinados à execução de ações de prevenção em áreas de risco de desastres e de resposta e de recuperação em áreas atingidas por desastres. 
A Figura 2.2 a seguir apresenta a evolução da Lei do RDC, a partir de suas ampliações:

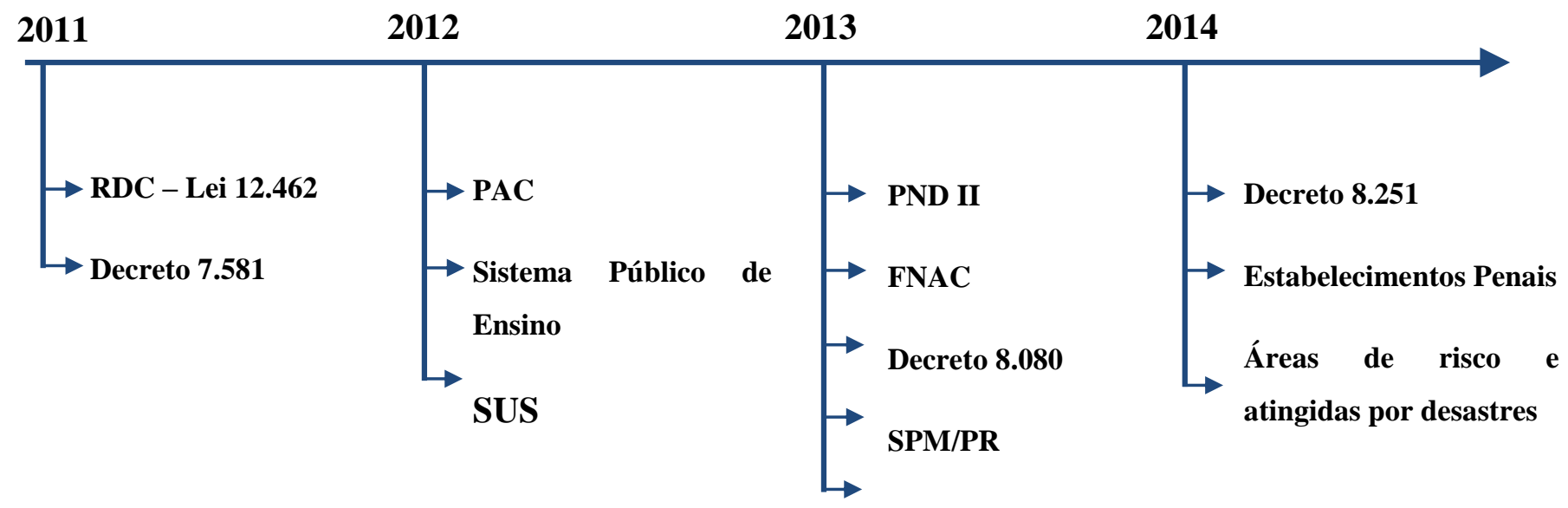

Figura 2.2 - Linha do Tempo do RDC

Fonte: Autor

Em síntese, a utilização do RDC somente é possível para os casos e tipologias de obras e serviços de engenharia permitidos nos termos das sucessivas ampliações deste regime. Prescinde observar que conforme prescrito no $\S 2^{\circ}$ ao art. $1^{\circ}$ da Lei $n^{\circ} 12.462$, de 2011 , sua utilização é permitida e não obrigatória, ou seja, mesmo nesses casos autorizados, a utilização do regime diferenciado é opcional.

As recentes alterações legislativas promovidas na área de licitações de obras públicas trazidas com a aprovação da Lei $\mathrm{n}^{\circ}$ 12.462, de 4/8/2011, que instituiu o Regime Diferenciado de Contratações Públicas - RDC estabeleceram no ordenamento jurídico brasileiro um novo regime de execução de obras públicas, denominado contratação integrada.

A contratação integrada compreende a elaboração e o desenvolvimento dos projetos básico e executivo, a execução de obras e serviços de engenharia, a montagem, a realização de testes, a pré-operação e todas as demais operações necessárias e suficientes para a entrega final do objeto, conforme Art. $9^{\circ}$ da Lei ${ }^{\circ} 12.462 / 2011$.

Assim, diferentemente do que ocorria nas licitações efetuadas com referência na Lei ${ }^{\circ}$ 8.666/93 em que a Administração utilizava o Projeto Básico como elemento técnico para 
embasar a contratação da obra, nesse regime a Administração a licitação é conduzida tendo como referência o Anteprojeto de Engenharia.

Especificamente o instrumento legal que possibilitou a regulamentação da precificação do risco (reserva de contingência) nas contratações integradas foi o Decreto $\mathrm{n}^{\circ} 8.080$, de 20/8/2013, a partir da inclusão dos parágrafos $1^{\circ}$ e $2^{\circ}$ do art. 75 do Decreto $\mathrm{n}^{\circ} 7.581$, de 11/10/2011, o qual regulamenta o Regime Diferenciado de Contratações Públicas - RDC.

Em que pese a indispensabilidade técnica do estabelecimento de um instrumento de alocação de riscos, registrasse que o texto legal do RDC não faz menção a necessidade de uma matriz de divisão de responsabilidades em relação aos riscos identificados.

Contudo, no âmbito jurisprudencial, em 19/6/2013, o Tribunal de Contas da União, em decisão emblemática exposta pelo Acórdão 1510/2013-TCU-Plenário, se manifestou pela obrigatoriedade da matriz de risco no caso da contratação integrada.

Segundo a supracitada decisão, a matriz de risco é o instrumento que define a repartição objetiva de responsabilidades advindas de eventos supervenientes à contratação, na medida em que é informação indispensável para a caracterização do objeto e das respectivas responsabilidades contratuais, como também essencial para o dimensionamento das propostas por parte das licitantes, é elemento essencial e obrigatório do anteprojeto de engenharia, em prestígio ao definido no art. $9^{\circ}, \S 2^{\circ}$, inciso I, da Lei 12.462/2011, como ainda nos princípios da segurança jurídica, da isonomia, do julgamento objetivo, da eficiência e da obtenção da melhor proposta.

Por sua vez, Altounian (2014) conceitualmente define matriz de risco como o instrumento que elenca e aloca entre as partes todos os eventos que podem impactar o empreendimento, em especial seus custos e prazos de execução.

O primeiro parágrafo do art. 75 conferiu à Administração discricionariedade para considerar no orçamento estimado do Anteprojeto de Engenharia taxa de risco compatível com o objeto da licitação e as contingências atribuídas ao contratado. Para tanto condicionou a utilização da referida taxa à devida motivação de acordo com metodologia definida em ato do Ministério supervisor ou da entidade contratante.

Da pesquisa realizada nos endereços eletrônicos institucionais dos principais órgãos e entidades federais executores de obras públicas que optaram por adotar o RDC, em sua 
modalidade de contratação integrada, verificasse que somente o DNIT (por meio da Instrução de Serviço/DG n ${ }^{\circ}$ 01, de 2/1/2014) e o Ministério da Integração Nacional (por meio da Portaria $\mathrm{n}^{\mathrm{o}} 118$, de 18 de março de 2014) desenvolveram e aprovaram metodologias de riscos para aplicação em suas obras.

O segundo parágrafo é explicitado que a referida taxa de risco não integrará a parcela de Benefícios e Despesas Indiretas - BDI do orçamento estimado, devendo ser considerada apenas para efeito de análise de aceitabilidade das propostas ofertadas no processo licitatório.

Segundo Cavalcante e Altounian (2014), a providência do Decreto foi salutar, posto que, em eventuais termos aditivos, o particular não alocará imediatamente aquele BDI global (recheado pelos riscos e incertezas) em serviços que não carreguem tal carga de imponderação.

$\mathrm{Na}$ sistemática de contratação integrada duas estratégias de alocação de risco ganham destaque, o seguro e a garantia contratual, ambas aprimoradas na legislação do RDC.

A Lei $n^{\circ}$ 12.462/2011 definiu, desde sua redação original, que a Administração observaria como diretriz de seus contratos condições de seguros compatíveis com as condições de mercado.

Adicionalmente, a Medida Provisória n 630, de 24/12/2013, posteriormente convertida na Lei $\mathrm{n}^{\circ}$ 12.980, de 28/5/2014, ampliou as condições de prestação de garantias pelos licitantes e pelos contratados também ao referencial de mercado.

Destaca-se que a referida medida provisória revogou o inciso III do $\S 2^{\circ}$ do art. $9^{\circ}$ da Lei $\mathrm{n}^{\circ}$ 12.462/2011, que impunha a obrigatoriedade da adoção do critério de julgamento de técnica e preço.

Importa registrar que o método tradicionalmente adotado no Brasil para orçamentação de obras é a inclusão de uma taxa de riscos ou contingências como um percentual fixo na composição do BDI (Acórdão 2622/2013-TCU-Plenário), tanto que foi positivado por meio do Decreto $\mathrm{n}^{\circ} 7.983$, de 8/4/2013, para ser seguido por órgãos e entidades da administração pública federal quando da elaboração do orçamento de referência de obras e serviços de engenharia, contratados e executados com recursos dos orçamentos da União. 
Importa destacar que o Acórdão 2622/2013-TCU-Plenário veio substituir os parâmetros dos Acórdãos 325/2007-TCU-Plenário e 2369/2011-TCU-Plenário, em virtude de divergências técnicas acerca dos valores admissíveis para taxas de BDI adotadas para detecção da existência de sobrepreços/superfaturamentos decorrentes da aplicação de taxas de BDI injustificadamente elevadas e quantificar o respectivo débito.

O referido acórdão foi fruto de um estudo que a partir de critérios contábeis e estatísticos definiu faixas aceitáveis para valores de taxas de BDI específicas para cada tipo de obra pública e para aquisição de materiais e equipamentos relevantes.

As Tabelas 2.1 e 2.2 apresentam as faixas percentuais das parcelas de i) risco e ii) seguro e garantia contidas na taxa de BDI por tipologia de obra e para fornecimento de materiais, respectivamente.

Tabela 2.1 - Faixas percentuais das parcelas de i) risco e ii) seguro e garantia contidas na taxa de BDI por tipologia de obra

\begin{tabular}{|c|c|c|c|c|c|c|}
\hline \multirow{2}{*}{ TIPOLOGIAS DE OBRA } & \multicolumn{3}{|c|}{ RISCO } & \multicolumn{3}{|c|}{ SEGURO + GARANTIA } \\
\hline & $1^{\circ}$ Quartil & Médio & $3^{\circ}$ Quartil & $1^{\circ}$ Quartil & Médio & $3^{\circ}$ Quartil \\
\hline Construção de edifícios & $0,97 \%$ & $1,27 \%$ & $1,27 \%$ & $0,80 \%$ & $0,80 \%$ & $1,00 \%$ \\
\hline $\begin{array}{l}\text { Construção de rodovias e } \\
\text { ferrovias }\end{array}$ & $0,50 \%$ & $0,56 \%$ & $0,97 \%$ & $0,32 \%$ & $0,40 \%$ & $0,74 \%$ \\
\hline $\begin{array}{l}\text { Construção de redes de } \\
\text { abastecimento de água, coleta de } \\
\text { esgoto e construções correlatas }\end{array}$ & $1,00 \%$ & $1,39 \%$ & $1,74 \%$ & $0,28 \%$ & $0,49 \%$ & $0,75 \%$ \\
\hline $\begin{array}{l}\text { Construção de manutenção de } \\
\text { estações e redes de distribuição de } \\
\text { energia elétrica }\end{array}$ & $1,00 \%$ & $1,48 \%$ & $1,97 \%$ & $0,25 \%$ & $0,51 \%$ & $0,56 \%$ \\
\hline $\begin{array}{l}\text { Obras portuárias, marítimas e } \\
\text { fluviais }\end{array}$ & $1,46 \%$ & $2,32 \%$ & $3,16 \%$ & $0,81 \%$ & $1,22 \%$ & $1,99 \%$ \\
\hline
\end{tabular}

Fonte: Acórdão 2622/2013-TCU-Plenário. 
Tabela 2.2 - Faixas percentuais das parcelas de i) risco e ii) seguro e garantia contidas na taxa de BDI para contratação de fornecimento de materiais e equipamentos

BDI PARA ITENS DE MERO FORNECIMENTO DE MATERIAIS E EQUIPAMENTOS

\begin{tabular}{c|c|c|c}
\hline PARCELA DO BDI & $\mathbf{1}^{\circ}$ Quartil & Médio & $\mathbf{3}^{\text {o }}$ Quartil \\
\hline RISCO & $0,56 \%$ & $0,85 \%$ & $0,89 \%$ \\
\hline SEGURO + GARANTIA & $0,30 \%$ & $0,48 \%$ & $0,82 \%$ \\
\hline
\end{tabular}

Fonte: Acórdão 2622/2013-TCU-Plenário

O Apêndice I traz a conceituação apresenta a trecho do Acórdão 2622/2013-TCU-Plenário referente à revisão da literatura dos componentes do BDI riscos, seguros e garantias.

O tema referente a seguros e garantias é apresentado à luz dos normativos da Superintendência de Seguros Privados - SUSEP, autarquia do Ministério da Fazenda responsável pelo controle e fiscalização dos mercados de seguro, previdência privada aberta, capitalização e resseguro no Brasil.

Destaca-se que ambas as exigências são estratégias de alocação de risco visando assegurar a execução da obra, no caso do seguro risco de engenharia e o adequado adimplemento do contrato, no caso do seguro-garantia.

Sobre o seguro risco de engenharia, o mesmo encontra-se regulado pela Circular SUPEP $\mathrm{n}^{\circ}$ 419, de 17 de janeiro de 2011. Dispõe sobre regras e critérios para operação das coberturas oferecidas em plano de seguro de Riscos de Engenharia, e dá outras providências.

Em relação ao seguro-garantia, destaca-se que o mesmo sofreu em 2013 significativa mudança, passando a ser disciplinado pela Circular SUSEP $n^{\circ} 477$, de 30 de setembro de 2013, que dispõe sobre o Seguro Garantia, divulga Condições Padronizadas e dá outras providências.

Nesse regramento a seguradora tem papel central nas mediações entre segurado e tomador, passando a ser um efetivo método de solução de conflitos, considerando o reestabelecimento da relação contratual entre as partes garantidas pela apólice de seguro. 
Impõe-se que tão logo realizada a abertura do processo administrativo para apurar possível inadimplência do tomador, este deverá ser imediatamente notificado pelo segurado, indicando claramente os itens não cumpridos e concedendo-lhe prazo para regularização da inadimplência apontada, remetendo cópia da notificação para a seguradora, com o fito de comunicar e registrar a Expectativa de Sinistro.

Dessa forma há uma nova dinâmica de gestão da garantia nos contratos do RDC, uma vez que os contratos sob a égide da Lei $\mathrm{n}^{\circ} 8.666 / 93$ continuam adstritos ao percentual de 5\%, ou a $10 \%$ no caso de obras de grande vulto, ao passo que na contratação integrada esses percentuais de cobertura podem ser ampliados de acordo com o diagnóstico da avaliação de risco, segundo a mesma lógica do setor privado.

Em síntese, a alteração promovida parte da realidade fática de que o baixo percentual autorizado pela Lei $n^{\circ} 8.666 / 93$ não contribui para que as apólices cumpram com o seu papel, que é garantir a conclusão do empreendimento quando da ocorrência de um sinistro.

Complementarmente impende destacar que no Brasil, os normativos da Associação Brasileira de Normas Técnicas (ABNT), ABNT NBR 13.531 (1995) e ABNT NBR 13.532 (1995), que abordam, respectivamente a conceituação e as peças técnicas que compõem o Anteprojeto de Engenharia não definem o intervalo de precisão de seu orçamento.

Já a referência do Conselho Federal de Engenharia e Agronomia, Confea (1991), estabelece apenas a precisão do projeto básico em mais ou menos $15 \%$, em que pese a existência de críticas doutrinárias em relação esse percentual, como a de Cavalcante e Altounian (2014).

Ante essa lacuna, recentemente o Instituto Brasileiro de Auditoria de Obras Públicas (IBRAOP), entidade que reúne profissionais inscritos no Sistema Confea/Creas que exercem atividades relacionadas à auditoria de obras públicas, publicou em 01/05/2012, a Orientação Técnica OT-IBR 004/2012, que estabelece parâmetros sobre a precisão do orçamento de obras públicas e traz para o Anteprojeto de Engenharia a faixa de precisão de $\pm 20 \%$, no caso de obras de edificações, em relação ao orçamento elaborado após a conclusão da obra, podendo ser superior em outras tipologias de obras.

E também complementa que o percentual de precisão do orçamento não deve ser considerado como risco ou contingências do construtor, sendo indevida sua inclusão no BDI do orçamento de obras públicas. 
Partindo do referencial de Mendes (2013), tem-se que a conclusão de uma obra pública licitada no regime de contratação integrada envolve o desempenho de atividades relacionadas a três fases destacadas: a) Fase do Anteprojeto de Engenharia; b) Fase de Licitação e c) Fase de Execução Contratual.

A análise do arcabouço normativo de contratação de obras públicas será efetuada á luz dos recentes julgados e jurisprudência do Tribunal de Contas da União, dado que a Administração deve acompanhar as deliberações do Tribunal quando da realização da contratação de obras públicas.

Ademais o grande quantitativo de fiscalizações de obras realizadas pelo TCU representa uma importante fonte de dados sobre os principais problemas existentes no planejamento, licitação, contratação e execução de obras no país. (BAETA, 2012)

O TCU desenvolve regularmente desde 1996 um programa permanente de auditorias em obras e serviços de engenharia, denominado Fiscobras, que visa subsidiar a decisão do Parlamento acerca do bloqueio ou liberação dos recursos necessários para a execução desses empreendimentos.

\subsection{PRÁTICAS INTERNACIONAIS PARA CONTRATAÇÃO E AVALIAÇÃo DE CONTINGÊNCIAS}

Neste tópico são apresentadas as seguintes referências: a) a disciplina federal sobre licitações nos Estados Unidos, Regulamento Federal de Aquisições (FAR) com destaque para a modalidade de licitação denominada contratação por negociação e especificidades no caso de obras rodoviárias; b) padrões de contrato da Federação Internacional dos Consultores de Engenharia (FIDIC) e c) as práticas recomendadas da Associação para o Desenvolvimento da Engenharia de Custos (AACE).

\section{a) Licitações Federais nos Estados Unidos da América}

O Regulamento Federal de Aquisições (na sigla em inglês, FAR - Federal Acquisition Regulation), FAR (2015) é o regulamento primário de contratação a ser observado pelas agências executivas federais. Atualmente sob o título 48, o FAR entrou em vigor em 1984 
e desde 2005 é mantido pelo Serviço Geral de Administração (General Service of Administration - GSA), pelo Departamento de Defesa (Departament of Defense - DOD) e pela agência de Administração Nacional da Aeronáutica e Espaço (National Aeronautics and Space Administration - NASA) no âmbito das orientações do Escritório Federal de Política de Aquisições (Office of Federal Procurement Policy - OFPP).

O FAR contém oito subcapítulos compostos por 53 partes, cada uma se referindo a um determinado aspecto do processo de aquisição governamental. Os métodos de contratação utilizados pelo governo federal americano são três e estão definidos nas partes 13 a 15 .

Conforme terminologia empregada por Santos e Tanaka (2014), os métodos de licitação são:

- Aquisição simplificada, definido na Part 13 - Simplified Acquisition Procedures;

- Licitação com proposta fechada, definido na Part 14 - Sealed Bidding; e

- Contratação por negociação, definido na Part 15 - Contracting by Negociation.

A aquisição simplificada tem aplicação muito restrita, em especial para o caso de obras, uma vez que a mesma está restrita ao limite de 150.000 dólares e dentre as outras opções, Cibinic et al (2011) chamam a atenção para o fato de que mais de $90 \%$ das compras governamentais federais norte-americanas adotam a contratação por negociação (também denominada negociação competitiva) em seus procedimentos licitatórios.

Conforme Relatório NCHRP 561 (2006), as contratações por negociação são também denominadas contratações "Best Value", "Melhor Valor" em tradução literal. Contratação por melhor valor é um processo de aquisição onde o preço e outros fatores-chave são considerados no processo de avaliação e seleção para minimizar os impactos e melhorar o desempenho e valor de construção de longo prazo.

Conforme Síntese NCHRP 390 (2009) e Gransberg e Shane (2015) os fatores denominados "soft" relacionadas com a competência gerencial e desempenho anterior são mais importantes para o processo de contratação (fase de pré-qualificação) do que os aspectos denominados "hard" relacionados com o preço.

Silva (2013) destaca que na modalidade de contratação por negociação o preço e outros fatores relacionados ao preço não são a base para a adjudicação. Santos e Tanaka (2014) 
reforçam que as aquisições competitivas são fruto de negociações em um ambiente de competição e o procedimento empregado tem como finalidade minimizar a complexidade da solicitação governamental, da avaliação e da escolha do fornecedor, ao mesmo tempo em que mantém um processo imparcial de análise das propostas, levando à seleção da proposta que representar o melhor valor para o governo.

Na seção 9.103 do FAR (2012) é destacado que a seleção unicamente pelo critério de menor preço cria a falsa impressão de que a administração esta fazendo uma boa aquisição e que embora seja importante que as compras governamentais sejam feitas pelo menor preço, isso não implica na contratação de um fornecedor somente porque ele ofertou o preço mais baixo.

Nesse ponto cabe destacar que a alteração efetuada pela Medida Provisória $n^{\circ}$ 630, de 24/12/2013, posteriormente convertida na Lei $n^{\circ} 12.980$, de 28/5/2014, com a revogação do inciso III do $\S 2^{\circ}$ do art. $9^{\circ}$ da Lei $\mathrm{n}^{\circ} 12.462 / 2011$, que impunha a obrigatoriedade da adoção do critério de julgamento de técnica e preço, promove um distanciamento de um aspecto central do modelo americano de contratação, do qual a contratação integrada veio inspirar-se, que é a seleção não somente baseada no critério preço.

A maldição do vencedor, relatada por Fiuza (2014), que se caracteriza pela subestimação do custo pelas empresas e elevados riscos de inexequibilidade do contrato, relacionados à vitória na licitação, não do concorrente mais eficiente, mas sim daquele que avaliou mal o custo da execução do serviço ou da produção do bem, é mitigada pela adoção de um critério de julgamento não fundado apenas no preço.

Conforme o FAR (2012) há uma fase específica para as aquisições competitivas negociadas em que deve ocorrer a troca de informações com a indústria antes da recepção das propostas dos licitantes.

O intercâmbio de informações com os potenciais contratantes é incentivado. A troca de informações deve ser consistente com os requisitos de integridade das licitações. As agências são incentivadas a promover, tão cedo quanto possível, o intercâmbio de informações sobre futuras aquisições.

O objetivo do intercâmbio de informações é melhorar a compreensão sobre as condições de contratação e a capacidade da indústria, permitindo, assim, que potenciais ofertantes julguem como eles podem satisfazer as exigências do governo, e reforçar assim sua 
capacidade para obter maior qualidade de bens e serviços, incluindo obras, preços razoáveis e aumentar a eficiência na preparação de propostas, avaliação de propostas, negociação e adjudicação do contrato.

$\mathrm{Na}$ fase de avaliação das propostas o governo verifica a capacidade dos licitantes para executar o possível contrato com sucesso, suas qualidades relativas exclusivamente sobre os fatores e subfatores especificados no edital, tendo como referência os seguintes requisitos de avaliação: a) o preço ou o custo para o governo; b) a qualidade do produto ou do serviço através da consideração de um ou mais fatores de avaliação que não envolvam custo, tais como o desempenho passado, conformidade com os requisitos de solicitação, excelência técnica, capacidade de gestão, qualificação de pessoal e experiência anterior; c) desempenho passado.

Nesse contexto, três fatores são de grande significância para o melhor desempenho das contratações de obras rodoviárias, conforme descritos nas Orientações FHWA (2004) e a seguir apresentados: a credibilidade do orçamento de referência (Engineer's Estimate) elaborado pela Administração, a avaliação do grau de competição de um certame (Assessing Competition) e a confidencialidade da estimativa final do custo, conforme a seguir descritos.

A revisão crítica do processo de contratação depende da confiabilidade do orçamento elaborada pela Administração, por isso as agências estaduais de transporte são fortemente incentivadas a proporcionar oportunidades de capacitação suficientes para o seu pessoal e a dedicar atenção suficiente para a preparação de estimativas e orçamentos usando o mesmo nível de detalhe da indústria da construção.

O orçamento de referência da Administração deve refletir o valor considerado justo e razoável que a Administração está disposta a pagar para o melhor resultado dos trabalhos. A subestimação causa atraso do projeto, dado que financiamento adicional tem de ser organizado para atender os custos do contrato. Por outro lado, a sobre estimação acarreta a utilização ineficiente de recursos que poderiam ser utilizados para outros projetos. Além disso, a orçamento da Administração serve como referência para a análise de propostas e é um elemento essencial no processo de aprovação do projeto (Orientações FHWA, 2004). 
Dessa forma, o primeiro aspecto de significância é a verificação da credibilidade de precisão (ou acurácia) do orçamento de referência da Administração (Engineer's Estimate), que é efetuada pela comparação com a oferta mais baixa do certame.

A exatidão da estimativa baseia-se na confiança de que a equipe de orçamentação irá usar todos os recursos disponíveis para produzir um valor justo e razoável para o trabalho, dado todas as condições e avaliar essas condições com precisão para estabelecer uma estimativa crível.

Considera-se que o orçamento de referência da Administração deve estar dentro da faixa de até $10 \%$ do preço mais baixo para, pelo menos, $50 \%$ dos projetos contratados.

Se este grau de precisão não é alcançado durante um período de tempo, como um ano, a confiança no orçamento de referência da Administração diminui. Além disso, se os custos de referencia da administração estão constantemente bem acima do preço mais baixo (da ordem de $15 \%$ a $20 \%$ ), tal prática induz os licitantes a apresentar propostas mais elevadas.

A Administração deve mostrar confiança em seu orçamento de referência e rejeitar os lances que não estão dentro do percentual razoável acima desse valor.

Em resumo, o orçamento de referência da Administração deve ser um valor justo e razoável para o trabalho a ser executado e deve estar compreendido dentro de mais ou menos $10 \%$ do preço para baixo para, pelo menos, $50 \%$ dos certames.

Explicita-se que em um universo de 1611 licitações avaliadas no Relatório do Departamento de Transportes Americano, USDOT (2015), em 774, ou 48\%, a estimativa final de custo de referência estava dentro da margem de $10 \%$ do lance mais baixo.

Essa linha de avaliação é particularmente interessante, pois define um critério de qualidade para o orçamento de referência elaborado pela administração tendo como pressuposto que deságios significativos decorrem de orçamentos sobreavaliados.

Ademais, o Relatório USDOT (2015) registra e incentiva o estabelecimento de procedimentos de estimativas de custos como uma boa prática a ser perseguida pelos órgãos estaduais de transporte daquele país.

O segundo aspecto de grande significância é a avaliação do grau de competição de um certame (Assessing Competition). 
A concorrência deve ser considerada excelente quando existem seis ou mais lances dentro do intervalo de até $20 \%$ a mais do menor preço. Um menor número de licitantes deve exigir avaliação específica para determinar se a concorrência foi adequada, e se há espaço para concorrência adicional ou se melhores preços poderiam ser obtidos. A título de orientação para esta determinação, os seguintes parâmetros são oferecidos como uma sugestão para determinar se uma concorrência adequada foi obtida:

Tabela 2.3 - Parâmetros para avaliação do grau de competição de um certame

\begin{tabular}{c|c}
\hline $\begin{array}{c}\text { Número de propostas competitivas * } \\
(* \text { Intervalo }=\text { menor preço }+\mathbf{2 0 \%})\end{array}$ & $\begin{array}{c}\text { A concorrência pode ser considerada adequada quando o } \\
\text { menor preço não excede ** }\end{array}$ \\
\hline 5 & $120 \%$ do Orçamento de referência \\
\hline 4 & $115 \%$ do Orçamento de referência \\
\hline 3 & $110 \%$ do Orçamento de referência \\
\hline 2 & $105 \%$ do Orçamento de referência \\
\hline 1 & Orçamento de referência \\
\hline $\begin{array}{l}\text { ** (Projetos do tipo excepcionais são identificados em virtude de concorrência historicamente baixa e } \\
\text { quando as perspectivas de aumento da concorrência não são aparentes. Tais projetos não devem ser } \\
\text { avaliados por esta diretriz) }\end{array}$ \\
\hline
\end{tabular}

Fonte: adaptado de Orientações FHWA (2004).

O terceiro aspecto discutido pelas Orientações FHWA (2004) envolve a confidencialidade do orçamento de referência da Administração. O referido Guia elenca os benefícios e desvantagens oriundos de cada uma dessas opções e pondera no sentido de que a confidencialidade do orçamento, obviamente, não vai por si só impedir que uma empresa conspire com outros licitantes, assim como não vai prevenir que licitantes saibam do valor aproximado que o órgão contratante está disposto a aceitar, uma vez que há uma grande pressão sobre os agentes públicos para disponibilização indevida de informações sigilosas.

Posto isso, as Orientações FHWA (2004) reconhecem que o total sigilo não é realista e apresenta, como uma tentativa mínima de confidencialidade, uma Tabela com intervalos para o orçamento de referência da Administração, conforme a seguir reproduzida (Tabela 2.4). 
Tabela 2.4 - Intervalo para o orçamento de referência da Administração

\begin{tabular}{c|c}
\hline Classificação de Projeto & Custo do Projeto - em dólar (\$) \\
\hline A & $0-100.000$ \\
\hline B & $100.000-250.000$ \\
\hline C & $250.000-500.000$ \\
\hline D & $500.000-1.000 .000$ \\
\hline E & $1.000 .000-2.500 .000$ \\
\hline F & $2.500 .000-5.000 .000$ \\
\hline G & $5.000 .000-10.000 .000$ \\
\hline H & $10.000 .000-15.000 .000$ \\
\hline I & $15.000 .000-25.000 .000$ \\
\hline J & 25.000 .000 ou maior \\
\hline
\end{tabular}

Fonte: Adaptado de Orientações FHWA (2004).

Importa registrar que o estabelecimento de uma classificação de referência para os orçamentos por intervalos pode contribuir para a mitigação do risco da prática de conluio observado por Baeta (2014), visto que no caso de orçamento sigiloso, o mecanismo dessa prática ilegal difere daquele observado nas licitações em que o orçamento é publico, situação em que as licitantes ofertam descontos irrisórios em relação à estimativa da Administração.

No RDC, quando há prática de conluio, o que se verifica é que todas as licitantes ofertam valores extremamente elevados, muito acima dos estimados pela contratante. Mesmo após a realização das fases de lances, todas as propostas ainda estão acima do preço estimado pela Administração. Então, a comissão de licitação é obrigada a chamar as licitantes para negociação, durante o qual é praxe exigir um determinado desconto daquela empresa que ofertou a melhor proposta. $\mathrm{O}$ desconto solicitado acaba por fornecer um parâmetro próximo ao preço sigiloso estimado pelo órgão contratante. Então, a empresa escolhida mediante esse ardiloso esquema de fraude simplesmente aceitará o preço ofertado na negociação pelo órgão contratante. (BAETA, 2014).

Baeta (2014) alerta que a empresa escolhida pelo grupo para vencer o certame pode ser aquela que ofertou o melhor lance ou pode ocupar uma posição intermediária no certame, 
situação em que as demais empresas que estejam mancomunadas não irão concordar com a negociação proposta pela comissão de licitação.

\section{b) Padrões de Contrato da Federação Internacional dos Consultores de Engenharia}

Em complementação aos aspectos de orçamentação propriamente dito, Bucker (2010), aponta que a adoção de contratos padronizados na área da construção civil está disseminada internacionalmente, sendo ainda pouco utilizada nos contratos submetidos à legislação brasileira ou para serem cumpridos no Brasil. Dentre os padrões, o padrão da Federação Internacional dos Consultores de Engenharia (FIDIC) é o mais importante.

A Fédération Internationale des Ingénieurs-Conseils (FIDIC) ou Federação Internacional dos Consultores de Engenharia foi fundada em 22 de Julho de 1913, por um grupo de três países, Bélgica, França e Suíça, com sede em Genebra, conforme contextualização e evolução histórica narradas por Teixeira (2013).

De acordo com Marinangelo e Klee (2014) a proposição de documentos-padrão extensos e já experimentados, com regulamentos detalhados e específicos das obrigações envolvidas, distribuição de riscos e procedimentos de solução de conflitos tem por finalidade, justamente, evitar lacunas, proporcionando maior segurança e previsibilidade na concretização de projetos de magnitude no campo da construção.

As condições contratuais FIDIC originam-se no exercício do direito anglo-americano e trazem importantes conceituações ao engenheiro de obras e demais agentes intervenientes no contrato sobre diversos temas, como por exemplo, reclamações (pleitos por adição de prazo contratual ou por custos adicionais), alocação de riscos, conselho de conciliação, dentre outros.

Sobre a arbitragem, Marinangelo e Klee (2014) destacam que no Brasil essa forma alternativa de solução de conflitos baseia-se principalmente nas regras da UNCITRAL (United Nations Comisssion on International Trade Law), sendo bastante utilizada em particulares. Entretanto na Administração Pública, sua utilização é controvertida, sendo que diversos doutrinadores ainda não aceitam formas alternativas de solução de conflitos. Alguns contratos, como o de Parcerias-Público-Privadas ou aqueles firmados sob a égide das normas FIDIC já preveem a hipótese de arbitragem. 
A tradição das contratações FIDIC está, desde o início, fundada no princípio de divisão de risco adequada entre o Dono da Obra (Employer) e o Empreiteiro (Contractor). Nos projetos de construção pautados pelos padrões FIDIC, as controvérsias são solucionadas, preferencialmente, pelos denominados métodos alternativos (ou seja, alternativas de conciliação por meio de tribunal adequado ou eventualmente por processo de arbitragem), cuja utilização é um dos princípios básicos do FIDIC. (MARINANGELO E KLEE, 2014).

Marcondes (2014) destaca que o contrato é o melhor instrumento de alocação de risco, vez que é por meio dele que as partes têm a chance de customizar, à luz das condições específicas do negócio que entabulam, como ficarão mais bem distribuídos os riscos.

Teixeira (2013) alerta que as formas contratuais FIDIC requerem um conhecimento alargado dos termos, o que obriga os potenciais utilizadores a um encargo financeiro direcionado para a participação em capacitações. Outro aspeto negativo é o excesso de tarefas alocadas ao Engenheiro sobrecarregando o mesmo. Neste ponto, o mesmo sugere que a função do Engenheiro deva ser levada a cabo por uma equipe desmembrada por frentes de execução.

\section{c) Práticas Recomendadas da Associação para o Desenvolvimento da Engenharia de Custos}

Especificamente em relação à orçamentação e precificação dos riscos que serão transferidos ao contratado - reserva de contingência, destacam-se as práticas recomendadas (RPs, abreviação de Recommended Practice) de análise de risco e determinação da reserva de contingência da AACE - Association for the Advancement of Cost Engineering International.

Importa preliminarmente destacar que não há nenhum normativo da Associação Brasileira de Normas Técnicas (ABNT) detalhando técnicas e ou procedimentos para o cálculo da reserva de contingência, razão pela qual todo o marco referencial utilizado é o das práticas recomendadas da AACE.

De acordo com a abordagem da prática recomendada da AACE RP 10S-90 (2013), contingência é um valor adicionado a uma estimativa para cobrir itens, condições ou eventos cuja ocorrência ou efeito é incerto, mas que a experiência mostra que 
provavelmente resultarão em custos adicionais. Normalmente é estimada utilizando análise estatística ou julgamento baseado em ativos passados ou projetos similares.

De outra forma, verifica-se que o nível de maturidade do projeto será determinante para a definição do valor a ser alocado à título de contingência, uma vez que quanto maior o nível de maturidade do projeto, menor a imprecisão do orçamento e menor também o valor da contingência. Analogamente, quanto menor o nível de maturidade do projeto, maior a imprecisão do orçamento e maior também o valor da contingência.

Sobre nível de maturidade de projeto e consequentemente de orçamento sobressaem três práticas recomendadas que compõem o Sistema de Classificação de Estimativas de Custos da AACE, RP 17R-97(2011), RP 18R-97(2011) e a RP 56R-08(2012), sendo a primeira a classificação geral e as duas seguintes adendos da primeira para empreendimentos de características específicas, indústrias de processo e indústria da construção em geral.

Destaca-se que as práticas de orçamentação envolvem estimativas para o investimento de capital e excluem as avaliações operacionais e de ciclo de vida. Além do mais, as práticas recomendadas são destinadas a fornecer uma orientação, não um padrão.

Nesse contexto a classificação geral tem como objetivo fornecer uma metodologia genérica de classificação das estimativas de custo do projeto em qualquer setor, sendo complementada com dois adendos que fornecem extensões e detalhes adicionais para indústrias específicas.

O termo indústrias de processos inclui empresas envolvidas com a fabricação e produção de produtos químicos, petroquímicos e processamento de hidrocarbonetos. O ponto em comum entre essas indústrias (para efeitos de classificação estimativa) é sua dependência de diagramas de fluxo de processo e diagramas de tubulação e instrumentos como documentos primários de definição do escopo. Estes documentos são os produtos principais para determinar o grau de definição do projeto e, portanto, a extensão e a maturidade de informação estimativa de entrada.

Construções que envolvem instalações de equipamentos mecânicos e processos químicos, também são consideradas em virtude da significativa quantidade de controles de tubulação, instrumentação e processos envolvidos. Complementarmente pode aplicar-se a porções de outras indústrias, como a farmacêutica, a utilidade, metalúrgico, conversão e indústrias similares. 
O termo construção em geral inclui tanto novas construções como reformas. Destina-se a ser utilizado para a construção de edificações e infraestrutura de serviços públicos, com ênfase em obras que executam atividades repetitivas. Exemplos de edificações incluem: construção residencial, edifícios comerciais, hotéis, resorts, escritórios, mercados varejistas, dentre outros. Exemplos de infraestrutura de serviços públicos incluem: telecomunicações, tubulações de água, tubulações de esgoto sanitário e obras hídricas, em geral.

Essas três práticas recomendadas constituem a base da ASTM, órgão americano de normatização, para o estabelecimento da classificação padrão de estimativas de custos, por meio da norma ASTM E2516-11 Standard Classification for Cost Estimate Classification System.

As referidas normas RP 18R-97(2011) e RP 56R-08(2012) também identificam os empreendimentos de não aplicabilidade.

A RP 18R-97(2011) não aborda estimativas de custo em setores não enquadrados na definição "indústrias de processo" como construção de edifícios comerciais, obras de recuperação ambiental, obras de infraestrutura de transporte, obras de energia hidrelétrica, processos "secos" como montagem e fabricação, produção de ativos intangíveis tais como desenvolvimento de software, e indústrias semelhantes. Também não trata especificamente de estimativas para a exploração, produção ou transporte de materiais de mineração ou de hidrocarbonetos, embora possa aplicar-se a algumas das etapas de processamento intermediário nestes sistemas.

Também não abrange as estimativas para os produtos fabricados pelas instalações de processamento ou para pesquisa e desenvolvimento em apoio às indústrias de processo. Não abrange a construção de edifícios significativos que pode ser uma parte de plantas de processo.

A RP 56R-08(2012) não aborda estimativas de custo em: indústrias de processo, obras de recuperação ambiental, obras de infraestrutura de transporte (horizontal), represas, reservatórios, túneis, processos como montagem e fabricação, produção de ativos intangíveis tais como desenvolvimento de software e indústrias similares. E também não cobre projetos específicos, como salas de concertos, estádios esportivos, prédios de pesquisa, centros de saúde, laboratórios de ciência e prédios de alta tecnologia. 
As estimativas de custos abrangidos pela RP 18R-97(2011) são específicos para contratos EPC (do inglês Engineering, Procurement and Construction), também denominados turnkey lump sum, modalidade de execução contratual, que se aproxima da empreitada integral prevista na alínea "e"do inciso VIII do art. $6^{\circ}$ da Lei $n^{\circ} 8.666 / 1993$, onde a contratada é responsável pelo fornecimento integral do objeto, incluindo fornecimento de materiais e equipamentos, construção, montagem e colocação em operação.

Por outro lado a RP 56R-08(2012) se aplica além do tradicional Design-Bid-Build (DBB) ${ }^{1}$, dentre elas o Design-Build (DB), como é conhecido na literatura internacional a contratação integrada.

Vale destacar que o Estudo FHWA (2006) cita os dois principais estudos, um americano e outro inglês, que compararam as metodologias de entrega de projetos Design-Build (DB) e a Design-Bid-Build (DBB), utilizando respectivamente dados coletados de 351 projetos de construção nos Estados Unidos e de 330 projetos no Reino Unido, os quais demonstraram que a forma de contratação $\mathrm{DB}$ foi mais vantajosa do que a forma $\mathrm{DBB}$, tanto em termos de redução de custo quanto de redução do cronograma.

A Tabela 2.5 a seguir apresenta a comparação entre as metodologias de entrega BD e DBB:

${ }^{1}$ Design-Bid-Build (DBB) - contratação com a realização de dois certames, sendo um para contratação do projeto e outro para a execução do empreendimento. 
Tabela 2.5 - Comparação entre as metodologias de entrega de Projetos Design-Build (DB) e a Design-Bid-Build (DBB)

\begin{tabular}{l|c|c}
\hline \multicolumn{1}{c|}{ Estudo } & $\begin{array}{c}\text { \% relativo de } \\
\text { redução no } \\
\text { Custo } \\
\text { DB x DBB }\end{array}$ & $\begin{array}{c}\text { \% relativo de } \\
\text { redução no } \\
\text { Cronograma } \\
\text { DB x DBB }\end{array}$ \\
\hline $\begin{array}{l}\text { J. Bennett, E. Pothecary \& G. Robinson, Designing } \\
\text { and Building a World-Class Industry, University of }\end{array}$ & & \\
$\begin{array}{l}\text { Reading Design and Build Forum Report, Centre for } \\
\text { Strategic Studies in Construction, Reading, United } \\
\text { Kingdom, 1996. }\end{array}$ & $13 \%$ & $30 \%$ \\
\hline $\begin{array}{l}\text { Victor Sanvido \& Mark Konchar, Selecting Project } \\
\text { Delivery Systems: Comparing Design-Bid-Build, } \\
\text { Design-Build, and Construction Management at } \\
\text { Risk, The Project Delivery Institute, State College, } \\
\text { PA., 1999. }\end{array}$ & $6 \%$ & \\
\hline
\end{tabular}

Fonte: Estudo FHWA (2006)

Em relação ao custo, o primeiro estudo revelou que a contratação DB diminuiu o custo em $13 \%$ quando comparado com a contratação DBB, já o segundo estudo registrou $6 \%$.

No que tange ao cronograma, o estudos inglês e americano chegaram em percentuais de diminuição mais significativos da contratação DB em comparação com a contratação DBB, da ordem de $30 \%$.

Por oportuno, é importante destacar que esses estudos foram elaborados em uma realidade muito diversa da atual, tanto em termos de soluções tecnológicas quanto devido ao significativo avanço das técnicas de orçamentação.

Ademais, destaca-se que na realidade americana, a forma de contratação Design-Build mantem-se estável ao longo dos últimos 9 anos e em 2013, encontra-se próxima do patamar de $40 \%$ do total de contratações realizadas, conforme observa-se na Figura 2.3, adaptada de RSMEANS (2014).

Importa consignar que na Figura 2.3 a sigla CM-at-Risk corresponde a forma de contratação Construction Management At-Risk, também designada pelas siglas CMAR e CM@R, que, conforme GÓMEZ et al (2006), é uma variedade da modalidade DesignBuild, com a diferença de que o risco é quase que totalmente assumido pelo contratante. 


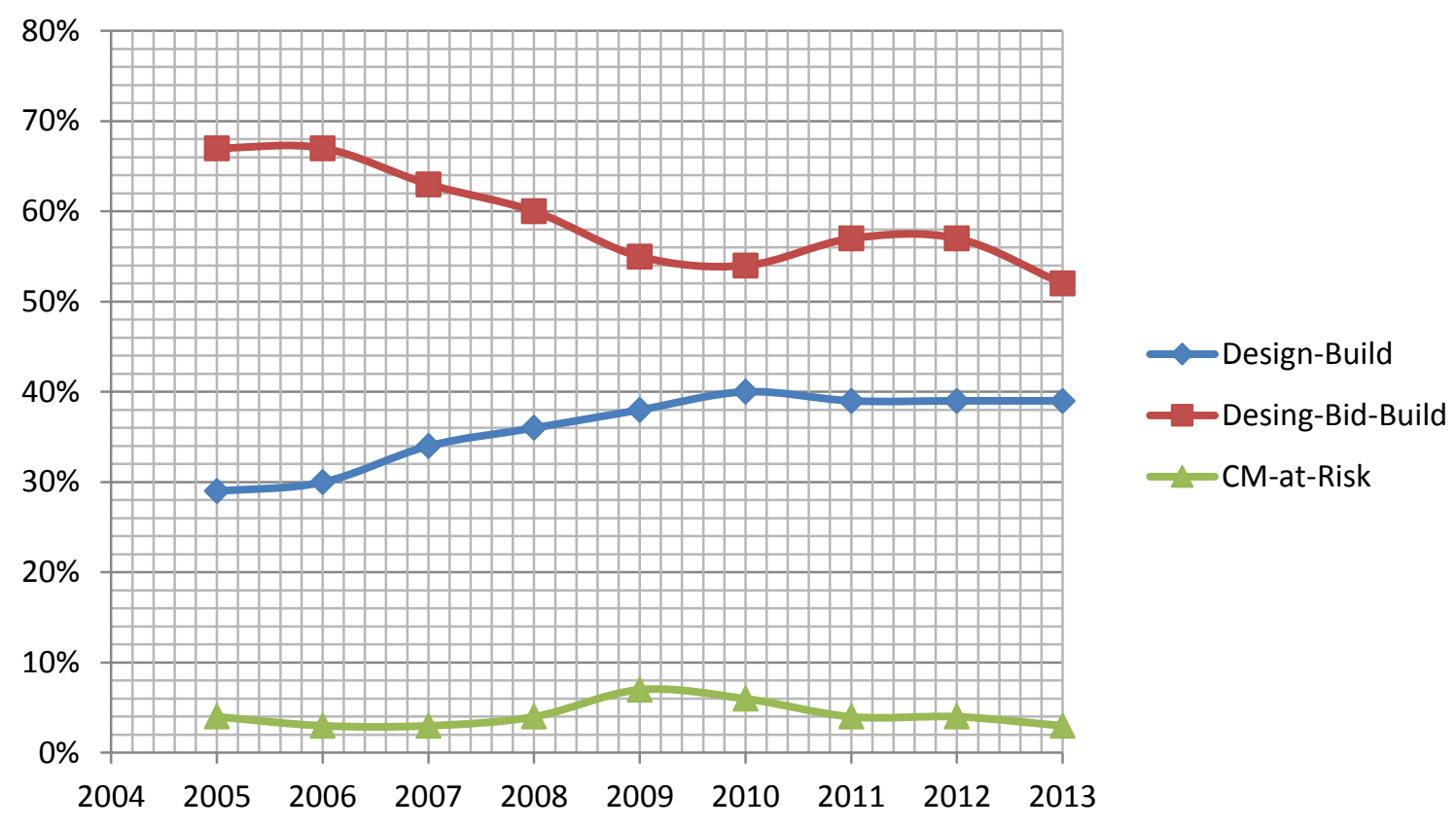

Figura 2.3 - Comparação entre as formas de contratação Design-Bid-Build e Design-Build. Fonte: Adaptado de RSMEANS (2014)

O mesmo estudo de RSMEANS (2014) destaca que o percentual de obras governamentais contratadas na modalidade Design-Build (BD) nos Estados Unidos, entenda-se contratação integrada, é em torno de 40\%, demonstrando que o regime tradicional ainda é majoritário nas contratações públicas americanas. Os percentuais por setor estão apresentados na Figura 2.4 


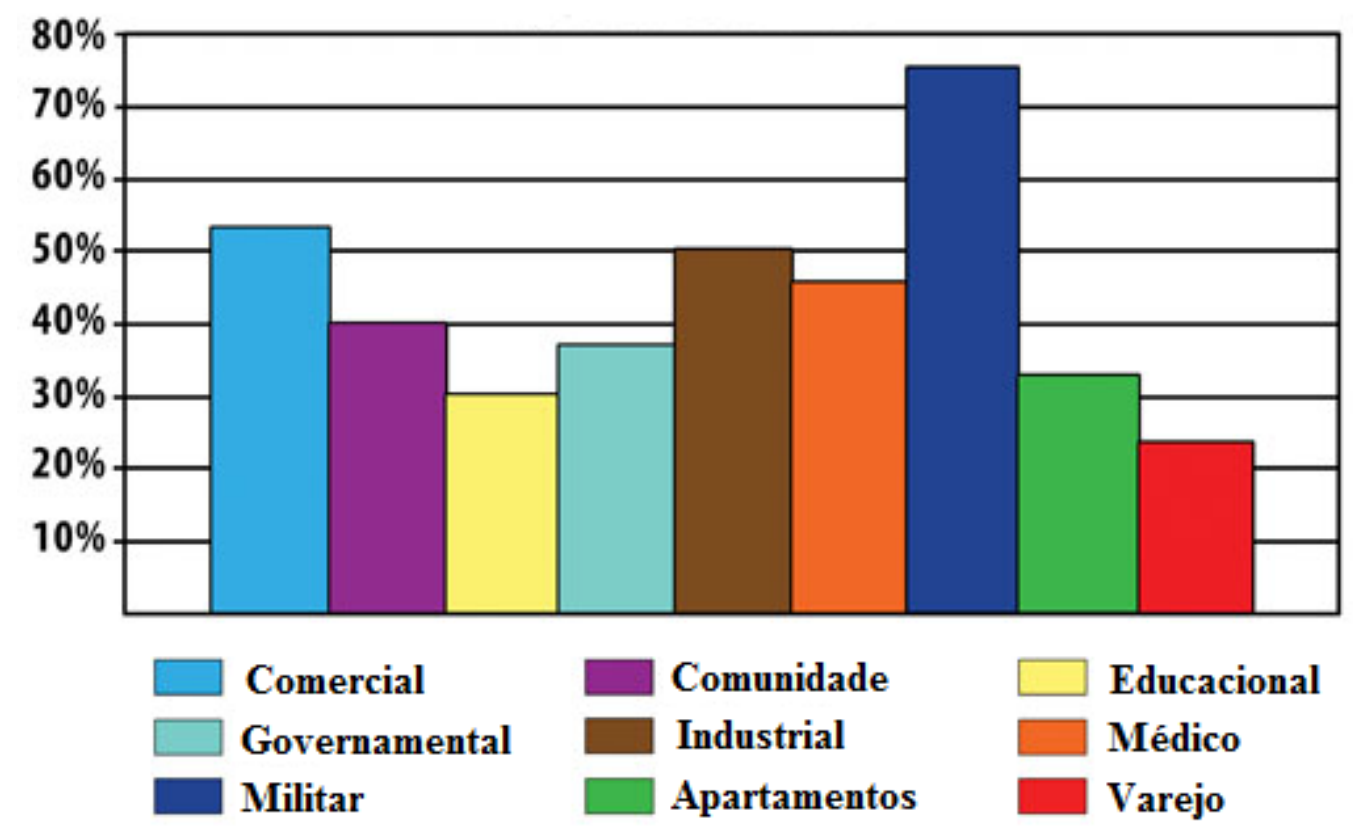

Figura 2.4- Percentual de contratações na modalidade Design-Build por setor Fonte: Adaptado de RSMEANS (2014)

Há inúmeras características que podem ser utilizadas para classificar os tipos de estimativas de custos. Os mais importantes são o nível de maturidade das entregas definidas no projeto, o uso final da estimativa, a metodologia de cálculo, a faixa (ou intervalo) de precisão esperado e o esforço necessário para preparar a estimativa. A característica "primária" utilizada para definir a categoria de classificação é o nível de maturidade das entregas definidas no projeto. As outras características são "secundárias".

A matriz de classificação correlaciona as características em 5 classes de estimativa. A estimativa Classe 5 refere-se ao mais baixo nível de definição do projeto e a estimativa Classe 1 é a mais próxima da definição do projeto completo.

Em linhas gerais, a faixa (intervalo) de precisão esperada é uma indicação do grau em que o resultado final do custo dentro de classe pode variar. A precisão é tradicionalmente expressa por um intervalo (+/-) percentual em torno do valor global da estimativa de custos, após a aplicação das contingências. À medida que o nível de definição de maturidade das entregas do projeto aumenta, a precisão da estimativa esperada tende a melhorar, como indicado por uma faixa mais apertada (+/-).

Além do nível de maturidade do projeto, a faixa de precisão esperada também é impulsionada por outros riscos sistêmicos, tais como: 
- Nível de tecnologia específica do projeto;

- Complexidade do projeto;

- Qualidade de dados de estimativas de custos de referência;

- Qualidade dos pressupostos utilizados na elaboração da estimativa;

- Experiência e nível de habilidade do estimador;

- Técnicas de estimativa empregadas; e

- Tempo e o nível de esforço utilizado para preparar a estimativa.

Os riscos sistêmicos são muitas vezes os principais definidores de precisão. Conforme a RP 42R-08 (2009) a compreensão dos tipos de riscos é fundamental, pois para cada tipo há um método de precificação mais adequado.

Conforme esta prática recomendada, os riscos sistêmicos são vinculados a cultura, a estratégia de negócios, a complexidade do sistema de processos, a tecnologia, e assim por diante. Medidas desses riscos são geralmente conhecidos ainda nas primeiras fases de definição do projeto, e, além disso, os impactos destes riscos tendem a ser altamente dominante para as estimativas iniciais. Além disso, a ligação entre os riscos sistémicos e os impactos de custos é de natureza estocástica; isto significa que é muito difícil para as equipes de projeto estimarem diretamente o impacto destes riscos sobre itens específicos ou atividades. Finalmente, os riscos sistémicos tendem a ser vinculados aos "proprietários"; ou seja, o contratante é responsável pela definição antecipada, planejamento, tecnologia e decisões, de modo que esses riscos não podem ser facilmente transferidos para empreiteiros durante a execução.

Ainda conforme a referida prática recomendada, os riscos específicos são estritamente vinculados às particularidades de cada empreendimento. Os riscos específicos de projeto são passiveis de compreensão individual e são negociáveis durante a estratégia de contratação do projeto. Exemplos desse tipo de riscos são vinculados aos seguintes fatores: chuva, condições do subsolo, atrasos na entrega, disponibilidade de recursos, problemas do time de projeto, problemas de qualidade que ocasionam retrabalho, dentre outros.

Tem-se, ainda, que toda faixa de precisão tem um grau de confiança a ela associado. Ademais, as faixas de precisão definidas na RP 18R-97(2011) e a na RP 56R-08(2012) 
referem-se a um grau de confiança de $80 \%$. Dessa forma, com base nessas práticas recomendadas, quando são estabelecidos os percentuais (para mais e para menos) da faixa de precisão lá sugeridos, garante-se $80 \%$ de probabilidade de que um empreendimento apresente seu custo final/real dentro daquele intervalo, mantido o escopo inicial daquela estimativa de custo.

O Apêndice II apresenta as matrizes de classificação de estimativas de custos das práticas recomendadas RP 17R-97(2011), RP 18R-97(2011) e a RP 56R-08(2012) e os gráficos que mostram as faixas (intervalos) de precisão para os empreendimentos da indústria de processo e da indústria da construção em geral.

Já a RP 40R-08 (2008) apresenta os princípios gerais obrigatórios que devem ser abordados quando do cálculo da contingência, correlacionando-os com os quatro métodos que podem ser utilizados para a efetiva quantificação, a seguir apresentados:

I. Opinião especializada;

II. Diretrizes pré-determinadas;

III. Análise de Simulação de Riscos, podendo ser adotada a metodologia da Faixa de Estimativa ou Valor Esperado; e

IV. Modelagem Paramétrica.

Os métodos híbridos são combinações dos métodos anteriores.

Com relação aos princípios, algumas considerações são a seguir apresentadas:

a) Objetivos, expectativas e necessidades do cliente devem ser determinados, assim como o nível do cliente de tolerância ao risco deve ser avaliada, uma vez que o orçamento ou cronograma pode ser o resultado mais provável ou o resultado mais conservador ou o resultado mais agressivo;

b) A quantificação dos riscos não é um fim em si mesmo, pois deve ser parte de processo de gestão de riscos;

c) Além de considerar os requisitos gerais do cliente e do processo, também devem ser consideradas características contextuais significativas, como por exemplo: fase do projeto e metodologias de cronograma; 
d) O processo de gerenciamento de risco começa com identificação de riscos e, portanto, qualquer método de estimativa de risco deve começar da mesma forma. Este processo deve considerar as incertezas inerentes da estimativa e eventos de risco (incluindo tanto riscos específicos do projeto e riscos externos que podem afetar o projeto);

e) Um processo abrangente de gestão de riscos requer compreensão clara de cada risco e seu impacto potencial. Os riscos devem ser continuamente avaliados durante todo o ciclo de vida de um projeto. Se a administração não pode ver explicitamente a conexão entre um determinado risco e o impacto potencial, então a gestão do risco durante a execução será difícil. Por conseguinte, deve ser claro na prática como cada estimativa de risco identificada está ligada ao impacto estimado;

f) O processo de estimativa em si não deve introduzir novos riscos (riscos secundários). Por exemplo, se muitos riscos são considerados, ou muitos itens de custos estão incluídos na faixa de estimativa, os fatores de risco importantes podem não chamar a atenção suficiente e, em alguns casos, a análise de custo pode ficar corrompida ou obscurecida. Se a estimativa de impacto de risco é muito baixa, ela irá distorcer o processo de controle de projeto como fará com que as equipes tentem contornar planos inadequados. Se a estimativa de impacto risco é muito alta, a história mostra que o excesso de fundos ou o tempo serão consumidos em detrimento da rentabilidade ou outras medidas de sucesso do projeto;

g) O empirismo como uma prática geral é baseada na tomada de experiência do passado para aplicação para o presente e o futuro. Qualquer método deve ser baseado pela experiência do passado. Empirismo implica captação objetiva da experiência através de medição e análise das práticas e resultados passados. Por exemplo, a pesquisa empírica tem demonstrado que há riscos sistêmicos que têm impactos razoavelmente previsíveis. Empirismo pode ser exercido diretamente através de métodos de quantificação paramétricos (por exemplo, com base na regressão) ou menos diretamente através do uso de lições aprendidas, benchmarking ou validação dos resultados da análise em relação aos dados históricos;

h) Nenhum algoritmo de estimativa ou de rotina irá fornecer estimativas confiáveis sem a participação de um estimador experiente e competente (neste caso, um 
analista de risco). A probabilidade de riscos secundários aumenta com a inexperiência e / ou incompetência dos praticantes. Quanto menos empirismo for incorporado no cálculo, mais crítico serão a experiência, habilidades e conhecimento do analista; e

i) A estimativa da contingência é sempre parte de uma decisão de gestão. $\mathrm{O}$ cliente pode usar os valores estimados de risco em uma simulação de caso de negócio para apoiar uma decisão de investimento, ou pode simplesmente decidir quanto da contingência irá incluir em um orçamento do projeto ou cronograma.

Métodos que não respeitam os aspectos apresentados dos princípios gerais não são adequados. Exemplo comum de método inadequado inclui o método "resto"; ou seja, que estabelece a contingência como a diferença entre a estimativa final de custo com um prédeterminado orçamento.

Além disso, orientações predeterminadas que desprezam os riscos e/ou não têm base no empirismo ou na experiência são inadequadas.

Com relação aos métodos para o cálculo da contingência, seus principais aspectos apresentados na prática recomendada RP 40RP-08 (2009) são a seguir destacados:

\section{Opinião Especializada}

Nesse método a decisão tem uma forte base na experiência e na competência em gestão e análise de risco do estimador. Este método complementa os demais com combinações híbridas pelo emprego de pareceres de peritos. No entanto, este método é altamente sujeito à imposição de risco secundário gerando resultados incompatíveis ou tendenciosos. Esse viés pode ser minimizado através da obtenção do consenso de vários peritos ou uma equipe experiente, desde que haja opinião variada, independente (ou seja, de modo a evitar o "pensamento de grupo").

\section{Diretrizes pré-determinadas}

Uma abordagem comum é estabelecer uma tabela de faixas de valores de contingência para cada uma estimativa. As vantagens do método são que ele é simples, compreensível e consistente. Os resultados das diretrizes são melhorados na medida em que o empirismo, experiência e resultados práticos são incorporados no desenvolvimento das orientações. 
Como o método é "simples", é frequentemente usado por pessoas inexperientes; portanto, as diretrizes devem ser claramente descritas, documentadas e apoiadas por treinamentos.

A desvantagem é que ele não pode efetivamente lidar com os riscos que são únicos para um projeto específico, ou riscos que são comuns, mas podem ter impactos excessivos sobre um determinado projeto. Por essa razão, é mais útil para as estimativas iniciais que envolvem riscos sistêmicos (ou seja, não específicos do projeto). Em todos os casos, os resultados devem ser complementados com opinião de especialistas.

\section{Análise de Simulação de Riscos}

Este método combina opinião de especialistas com um modelo analítico que é então utilizado em uma rotina de simulação para fornecer uma saída probabilística. Os métodos mais comuns em uso são a metodologia da Faixa de Estimativa e o Valor Esperado, ambos os quais usam Monte Carlo ou rotinas de simulação semelhantes.

Conforme RP 41R-08 (2008) as funções densidades de probabilidade que mais razoavelmente refletem o comportamento dos fatores de risco em uma simulação de Monte Carlo são a distribuição triangular e a distribuição duplo triangular. Segundo esta orientação, um dos erros comuns é utilizar a distribuição triangular sem a devida verificação de que ela realmente é aplicável.

Na maioria dos casos, a distribuição duplo triangular é uma aproximação melhor do que a triangular tradicional, uma vez que o duplo triângulo permite que o analista de risco use o valor que a equipe de projeto acredita ser o mais provável, ao invés de deixar a distribuição triangular ditar uma probabilidade.

Importa destacar que a distribuição duplo triangular representa a junção de duas distribuições triangulares, uma representando valores menores que a estimativa mais provável e outra representando valores maiores que a estimativa mais provável. Frisa-se que a distribuição duplo triangular requer a especificação de uma função personalizada de modo que possa ser abordada a descontinuidade.

A RP 41R-08 (2008) cita que Curran (1989) demonstrou que em praticamente todos os projetos a incerteza está concentrada em um seleto número de itens críticos - tipicamente 20 ou menos, conforme a Lei de Pareto. Em raras ocasiões, pode haver mais de 20 itens críticos ou haver número inferior a 10 . Se isso ocorrer, o analista de risco deve reexaminar 
com cuidado os itens para ter certeza de que os itens críticos foram devidamente identificados.

A escolha da probabilidade desejada em uma simulação depende da atitude de risco da gestão. Uma boa estimativa deve ter igual probabilidade (ou seja, uma probabilidade de $50 \%$ ) de ser ou não superada, sendo esta uma abordagem neutra ao risco.

A atitude mais conservadora, avessa ao risco usada por muitas empresas com fins lucrativos, é especificar uma probabilidade de $80 \%$ (ou superior) para não ser superada. Esta é uma via mais segura, contudo especificando uma elevada probabilidade, a contingência necessária irá aumentar e com isso o custo do projeto. Isto resulta numa má distribuição de fundos, visto que grandes contingências sequestram recursos que poderiam estar sendo alocadas em outras finalidades.

A RP 44R-08 (2012) registra que muitas vezes, constrangido pelo tempo, as equipes ignoraram o esforço de mitigação e se detém direto na estimativa de contingência que frustra grande parte do propósito de agregação de valor da gestão de risco.

\section{Modelagem Paramétrica}

Um modelo paramétrico é geralmente um algoritmo que é derivado da análise de regressão linear multi-variável de fatores de risco quantificados contra o crescimento dos custos ou resultados de cronograma para projetos históricos.

Uma desvantagem do método é a complexidade do desenvolvimento do modelo paramétrico que requer habilidades estatísticas e dados históricos. $\mathrm{O}$ método também não lida efetivamente com os riscos que são únicos para um projeto específico, ou riscos que são comuns, mas podem ter impactos desordenados ou incomuns em um determinado projeto.

A RP 42R-08 (2009) destaca a metodologia de previsão de classe de referência de Flyvbjerg (2006) para avaliar o impacto do risco político, tais como o viés otimista e outro considerado como deturpação estratégica, e a incorporação de técnicas paramétricas para melhor medição do mesmo, particularmente para megaprojetos de infraestrutura financiados pelo governo. 


\section{Métodos Híbridos}

Cada um dos métodos de cálculo de contingências tem vantagens e desvantagens. Portanto, a melhor abordagem é, por vezes, a utilização de dois ou mais métodos para estimar o risco de custo e risco de cronograma. A combinação mais comum é a utilização de opinião de especialistas com qualquer outro método. Outra combinação é usar um modelo paramétrico para os riscos sistémicos e análise de simulação para riscos específicos do projeto. Modelos paramétricos também podem fornecer os resultados para o desenvolvimento das diretrizes pré-determinadas.

De acordo com a prática recomendada AACE 57R-09 (2011), os riscos de cronograma tem sido tipicamente ignorados nas avaliações de risco de custo, contudo, a metodologia descrita na referida norma imprescinde de um cronograma com as durações dos serviços devidamente detalhadas pelo método do caminho crítico (CPM), o que em regra, não se tem para um Anteprojeto de Engenharia.

À título de finalização, tem-se que a revisão bibliográfica demonstrou que há um vasto referencial técnico sobre gerenciamento de riscos, em especial sobre avaliação de contingências que não está devidamente incorporado aos normativos nacionais. 


\section{MÉTODO}

A contratação integrada, além de ser um tema novo no escopo das obras públicas brasileiras, abrange consigo nessa nova sistemática de licitação, aspectos sobre alocação e precificação de risco, cujos contornos não estão estabelecidos em normatização técnica nacional, exigindo nesse atual estágio de desenvolvimento ainda maior atenção por parte de todos os agentes envolvidos na cadeia de valor que abrange a contratação e execução de obras públicas.

Nesse contexto, a presente pesquisa tem caráter eminentemente exploratório e foi estruturada na forma de estudo de caso, em uma pesquisa de natureza qualitativa, especialmente decorrente da limitada base de dados de licitações envolvendo a contratação integrada.

A título esquemático apresenta-se na Figura 3.1 o fluxograma com a sequência de etapas do método de pesquisa empregado:

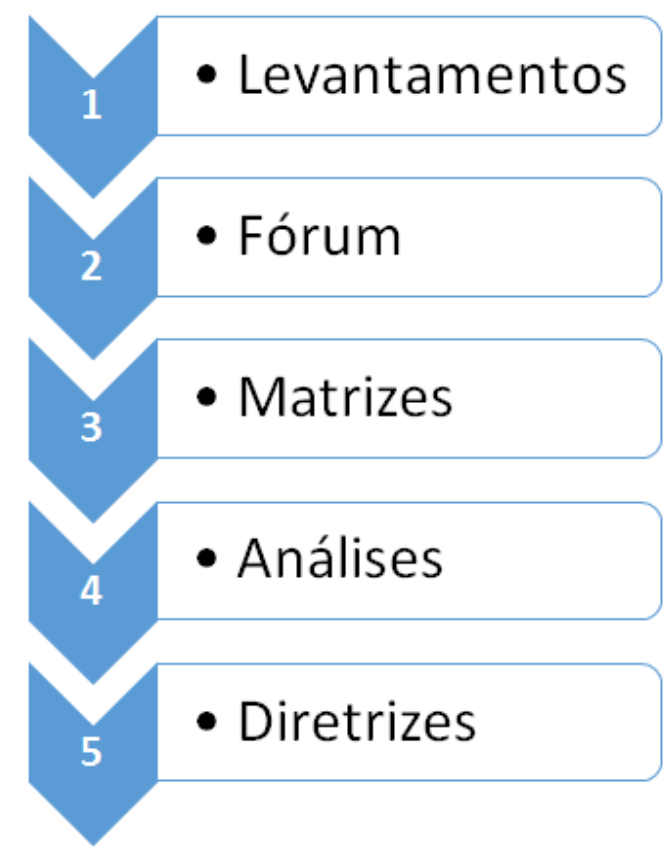

Figura 3.1 - Fluxograma do método de pesquisa.

Fonte: autor.

Os levantamentos possibilitaram reunir as referências teóricas sobre o tema gerenciamento de riscos, quantificar as licitações que foram homologadas na modalidade contratação integrada no período de referência da pesquisa, levantar as metodologias de riscos que 
foram elaboradas no âmbito da Administração Pública Federal, além de identificar todas as fiscalizações que foram realizadas nesse regime de execução pelo Tribunal de Contas da União.

Em sequência, as informações reunidas e sistematizadas foram utilizadas como a base para a formulação dos temas, palestras e convite às instituições para a realização de um Fórum que oportunizasse debates entre os órgãos públicos contratantes e discutisse as principais oportunidades e dificuldades enfrentadas como foco na gestão de riscos.

As discussões e reflexões ocorridas durante o Fórum enriqueceram a compreensão dos levantamentos realizados e possibilitaram avaliar as metodologias de precificação instituídas no âmbito da Administração Pública Federal de modo a permitir desenvolver dois instrumentos (matrizes) de avaliação do nível de maturidade dos órgãos em relação ao gerenciamento de riscos tendo como métrica o arcabouço jurídico.

$\mathrm{Na}$ etapa de Análise, foram realizadas as avaliações da prática observada nos empreendimentos licitados pelos órgãos e entidades do Poder Executivo Federal que optaram por adotar o RDC, em sua modalidade de contratação integrada, sobre uma perspectiva gerencial tendo como referência o estágio de maturidade e as fiscalizações e deliberações do Tribunal de Contas da União em relação aos principais aspectos levantados na revisão bibliográfica.

As diretrizes para o gerenciamento de riscos se constituem no resultado da consolidação dos principais aspectos observados na revisão bibliográfica, nas licitações propriamente ditas, nas fiscalizações realizadas pelo TCU e nas metodologias instituídas pelos órgãos do Poder Executivo Federal para precificação de riscos, apresentados tendo como referência cada um dos seis processos (ou fases) de gerenciamento de risco preconizados no Guia PMBOK (2013).

O detalhamento pormenorizado de cada uma das etapas é apresentado na sequência.

\subsection{ETAPA 1 - LEVANTAMENTOS}

Esta etapa compreendeu a realização de 3 tipos de levantamentos para a coleta de dados sobre o tema gerenciamento de riscos: 


\subsubsection{Levantamento do referencial teórico}

O levantamento envolveu tanto referências nacionais como internacionais e ocorreu por meio de consultas à artigos publicados em periódicos; obras, em especial livros, mas também guias e cartilhas, dentre outros; e legislação sobre o tema, a seguir apresentados de forma agrupada.

A legislação de referência do Regime Diferenciado de Contratações (RDC) e, por conseguinte da modalidade de execução contratação integrada, foi identificada, visto que ocorreram inúmeras alterações e ampliações do referido regime, incluindo a exigência obrigatória da previsão de matriz de risco em todas as licitações na modalidade contratação integrada, nos termos do Acórdão 1510/2013-TCU-Plenário.

Priorizou-se a busca por artigos publicados até no máximo nos cinco anos e em periódicos internacionais classificados nos três mais elevados estratos indicativos de qualidade da Coordenação de Aperfeiçoamento de Pessoal de Nível Superior (Capes), A1, A2 e B1.

Em relação aos modelos de gerenciamento de projetos e riscos, foram consultados os principais modelos consagrados internacionalmente, Guia PMBOK (2013), PRINCE2 (2009) e os normativos da International Organization for Standardization - ISO.

Em relação às referências americanas, foram pesquisados normativos e trabalhos técnicos nos seguintes órgãos: Serviço Geral de Administração (responsável pelo Regulamento Federal de Aquisições), Departamento de Transportes da Califórnia, Departamento de Transportes Americano, Entidade Fiscalizadora Superior - Government Accountability Office (GAO), órgão americano de normatização e a Associação para o Desenvolvimento da Engenharia de Custos, Association for the Advancement of Cost Engineering International - AACE, especialmente as práticas recomendadas observadas para alocação e precificação de riscos.

Em relação aos contratos, foram pesquisadas as referências da Federação Internacional dos Consultores de Engenharia.

Sobre o regime diferenciado de contratações, além das consultas efetuadas nos catálogos digitais de editoras nacionais especializadas em licitações e contratos, foram realizadas pesquisas visando identificar publicações técnicas nos endereços eletrônicos institucionais dos seguintes órgãos: Controladoria-Geral da União - CGU; Consultorias Legislativas da 
Câmara dos Deputados e do Senado Federal; Escola Nacional de Administração Pública ENAP; Instituto de Pesquisa Econômica Aplicada - IPEA; Ministério do Planejamento, Orçamento e Gestão; e Tribunal de Contas da União - TCU.

Sobre gestão de seguros e garantias, o levantamento teve como referências os normativos da Superintendência de Seguros Privados - SUSEP, principal órgão regulador do referido mercado.

Em relação à outros aspectos orientativos e normativos, destaca-se que foram efetuados levantamentos no seguinte conjunto de instituições: Associação Brasileira de Normas Técnicas - ABNT, Conselho Federal de Engenharia e Agronomia - CONFEA; Instituto Brasileiro de Auditoria de Obras Públicas - IBRAOP e em todos os órgãos e entidades do Poder Executivo Federal, objeto deste trabalho, que optaram por adotar o RDC, em sua modalidade de contratação integrada, visando identificar quais aprovaram metodologia para precificação de riscos.

Destaca-se que as referências acima expostas não representam a totalidade dos levantamentos efetuados, visto que novas consultas foram realizadas a partir desses referenciais.

As citações em relação aos referências teóricos levantados estão consignadas no texto que compõe o capítulo de revisão bibliográfica.

\subsubsection{Levantamento de licitações homologadas na modalidade de contratação integrada} até 2014

O fundamento para a realização do levantamento via consultas na internet reside no dever imposto pela Lei $\mathrm{n}^{\circ}$ 12.527, de 18/11/2011, denominada Lei de Acesso à Informação, aos órgãos e entidades públicas de promover, independentemente de requerimentos, a divulgação em local de fácil acesso, no âmbito de suas competências, de informações de interesse coletivo ou geral por eles produzidas ou custodiadas, dentre elas, informações concernentes a procedimentos licitatórios, inclusive os respectivos editais e resultados, bem como a todos os contratos celebrados.

Para a realização do levantamento quatro referências foram estabelecidas, a seguir apresentados: 
a) Referencial de sucesso: o levantamento abordou apenas licitações homologadas, visto que o objetivo é compor uma carteira de empreendimentos que possam ser avaliados em sua completude, mesmo que seja em etapas de pesquisa posteriores, visto que não há um número significante de empreendimentos concluídos realizados sob a forma contratação integrada que possibilitem uma análise objetiva representativa. Assim, licitações desertas, fracassadas ou revogadas não foram contabilizadas.

b) Referencial temporal: o levantamento foi realizado à partir de 2011, ano em que foi instituído a Lei ${ }^{\circ}$ 12.462/2011 e legislação que ampara o regime de contratação integrada, até homologação em 2014, visto que o ano de 2015 ainda está em curso;

c) Referencial político-administrativo: o levantamento foi realizado em órgãos e entidades vinculados ao Poder Executivo Federal, dado que ocorreram poucos empreendimentos licitados pelos Estados, Distrito Federal e Munícipios;

d) Referencial locacional: o levantamento abordou apenas certames realizados por órgãos/entidades vinculados ao Poder Executivo Federal sediados em Brasília/DF, com o objetivo de facilitar posterior interlocução e obtenção dos dados de cada empreendimento.

A estratégia adotada possibilita não só simplificar a consolidação de dados, mas principalmente facilitar a continuidade da pesquisa e o acompanhamento da evolução jurisprudencial, pela incorporação de novos conjuntos de licitações e novas fiscalizações realizadas pelos órgãos de controle a cada ano.

Uma vez que há uma identidade padrão de comunicação digital do Poder Executivo Federal, todas as consultas foram realizadas, à exceção das empresas públicas, no item "Licitações e Contratos" parte do Menu "Acesso à Informação".

Nas empresas públicas consultadas Infraero e VALEC há um acesso específico denominado "Licitações" na página principal de seus endereços eletrônicos institucionais.

Assim, foi realizado o levantamento via consultas aos endereços eletrônicos institucionais de órgãos e entidades federais executores de obras públicas visando identificar quais optaram por adotar o RDC, em sua modalidade de contratação integrada, a partir da verificação de informações disponibilizadas sobre certames realizados. 
Foram pesquisados um total de 10 órgãos/entidades em que é possível enquadrar os casos e tipologias de obras e serviços de engenharia permitidos nos termos das sucessivas ampliações do RDC.

Nos seguintes órgãos foram identificadas licitações na modalidade contratação integrada:

a) Departamento Nacional de Infraestrutura de Transportes - DNIT;

b) Engenharia, Construções e Ferrovias S.A - VALEC;

c) Empresa Brasileira de Infraestrutura Aeroportuária - Infraero;

d) Ministério da Integração Nacional;

e) Secretaria de Portos.

Cabe registrar que o referido levantamento foi realizado em 5 outros diversos Órgãos e Entidades que estão aptos, nos termos da lei, para realizar licitações pelo Regime Diferenciado de Contratações - RDC, mas que não realizaram licitações na modalidade de execução contratação integrada.

- Secretaria de Políticas para as Mulheres

- Ministério da Justiça

- Companhia Nacional de Abastecimento - Conab

- Empresa de Pesquisa e Logística - EPL

- Fundo Nacional de Desenvolvimento da Educação - FNDE

Em complementação, ressalta-se que duas pastas não foram consideradas na amostra. $\mathrm{O}$ Ministério das Cidades uma vez que tem como característica a aplicação descentralizada dos recursos dessa pasta por parte dos entes estaduais e municipais. A Secretaria de Aviação Civil no período da pesquisa realizou um único certame (licitação RDC eletrônico 2014/04.386, lançada pelo Banco do Brasil S.A.) na modalidade contratação integrada para as obras do terminal de passageiros de Barreiras/BA, contudo, o referido certame foi revogado.

As licitações que foram homologadas até 2014 foram sistematizadas em ordem cronológica por órgão/entidade, conforme modelo a seguir no Quadro 3.1. 


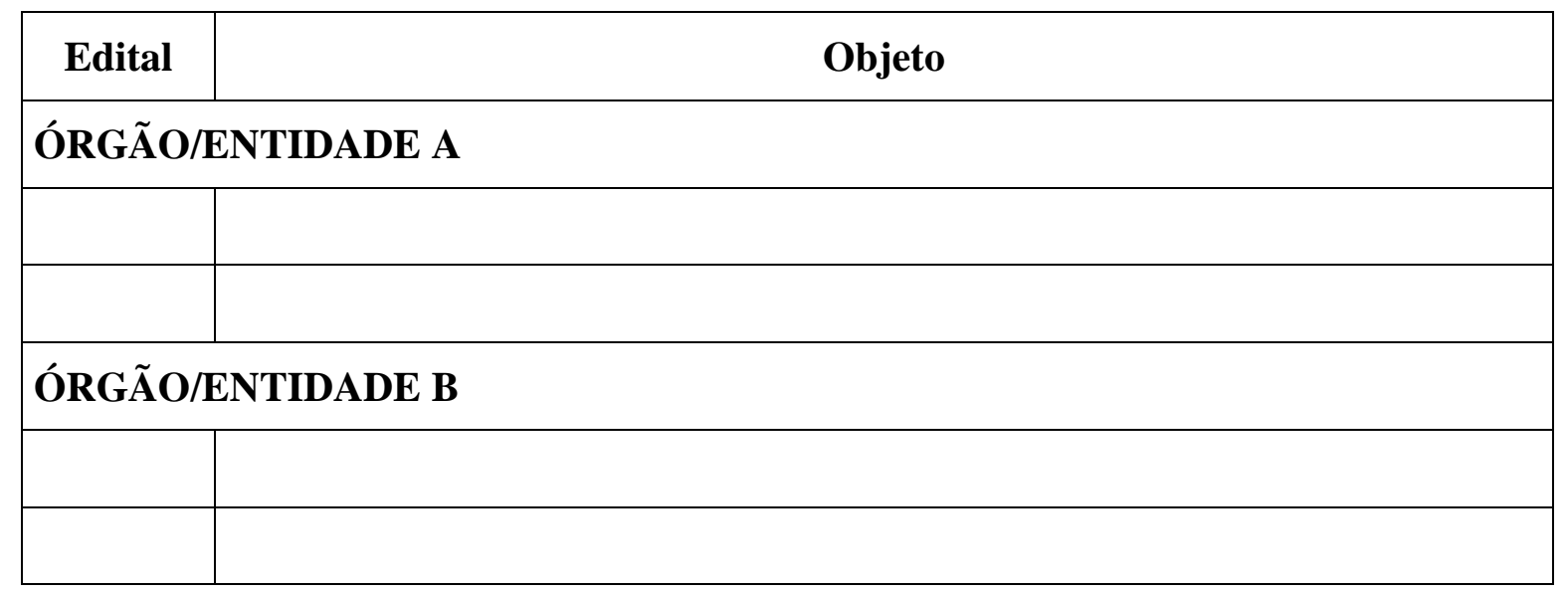

Quadro 3.1 - Licitações por órgão/entidade do Poder Executivo Federal efetuadas na contratação integrada homologadas até 2014

Fonte: Autor.

Em seguida, foi realizada a quantificação dos certames anteriormente identificados em relação às três inovações legislativas e uma jurisprudencial relacionadas ao gerenciamento de riscos, a seguir apresentadas por ordem cronológica:

- Diretriz para utilizar condições de seguros compatíveis com as condições de mercado, prevista desde a redação original da Lei $n^{\circ}$ 12.462, em 04/08/2011;

- Obrigatoriedade da matriz de risco no caso da contratação integrada, a partir do Acórdão n 1.510/2013-TCU-Plenário, de 19/6/2013;

- Possibilidade de ser considerada taxa de risco compatível com o objeto da licitação e as contingências atribuídas ao contratado, incluída pelo Decreto $n^{\circ} 8.080$, de 20/8/2013; e

- Diretriz para utilizar condições de garantias compatíveis com as condições de mercado, a partir da Medida Provisória $n^{\circ}$ 630, de 24/12/2013, posteriormente convertida na Lei ${ }^{\circ} 12.980$, de 28/5/2014.

O resultado da quantificação é apresentado na forma da Tabela conforme modelo a seguir apresentado no Tabela 3.1. 
Tabela 3.1 - Quantitativo de licitações homologadas na modalidade contratação integrada

\begin{tabular}{c|c|c|c|c|c}
\hline $\begin{array}{c}\text { Órgão / } \\
\text { Entidade }\end{array}$ & $\begin{array}{c}\text { Quantitativo de } \\
\text { licitações homologadas } \\
\text { na modalidade } \\
\text { Contratação Integrada } \\
\text { (referência: Dez/2014) }\end{array}$ & $\begin{array}{c}\text { Matriz de } \\
\text { Risco }\end{array}$ & $\begin{array}{c}\text { Precificação do } \\
\text { Risco (Reserva } \\
\text { de } \\
\text { Contingência) }\end{array}$ & $\begin{array}{c}\text { Condições de } \\
\text { seguros } \\
\text { compatíveis } \\
\text { com o } \\
\text { mercado }\end{array}$ & $\begin{array}{c}\text { Condições de } \\
\text { garantias } \\
\text { compatíveis } \\
\text { com o } \\
\text { mercado }\end{array}$ \\
\hline & & & & & \\
\hline
\end{tabular}

Fonte: Autor.

Destaca-se que a ação de levantamento e quantificação das licitações exige a leitura dos editais e demais documentos que compõem o mesmo, de modo que essa ação possibilitou levantar também quais foram as metodologias de riscos que foram elaboradas no âmbito da Administração Pública Federal.

Após a identificação de quais foram os órgãos que mais se notabilizaram por realizar certames na modalidade contratação integrada, foram agendadas reuniões que tiveram como objetivo principal incluir a experiência desses órgãos na pesquisa por meio da obtenção da permissão de acesso aos dados das análises de risco realizadas e das medições efetuadas dos contratos firmados na modalidade contratação integrada, visando identificar a ocorrência de variações de custo e/ou variações de prazo no âmbito de cada contrato, contudo, não foi possível o pleno acesso ao conjunto de dados necessários que possibilitariam a avaliação sobre o andamento dos empreendimentos.

Assim foram efetuadas ligações, por meio do contato telefônico disponibilizado nos endereços eletrônicos dos órgãos, visando o agendamento com os responsáveis das áreas de engenharia pelas licitações na modalidade contratação integrada de uma reunião para apresentação do tema da pesquisa, da proposta do trabalho acadêmico, em especial obter dados sobre o cronograma físico-financeiro realizado para confrontá-lo com o cronograma físico-financeiro planejado, através dos índices de desempenho da Análise de Valor Agregado (Earned Value Analysis).

\subsubsection{Levantamento das fiscalizações realizadas no âmbito do Fiscobras pelo Tribunal de} Contas da União na modalidade de contratação integrada

O levantamento das fiscalizações realizadas pelo Tribunal de Contas da União foi realizado objetivando abordar na pesquisa a ótica do controle, como função de retroalimentação do 
planejamento, conforme o ciclo $\mathrm{PDCA}^{2}$, e assim ampliar o enfoque para além da perspectiva da Administração Pública contratante.

Foi realizado levantamento na seção "Orçamento" do endereço eletrônico institucional da Câmara dos Deputados, nas informações encaminhadas sobre obras e serviços com indícios de irregularidades graves, para subsidiar a discussão das Leis Orçamentárias Anuais de 2012 até 2015.

Para cada lei orçamentária anual consta relação de relatórios encaminhados pelo Tribunal de Contas da União, no âmbito de cada plano anual de fiscalização de obras (Fiscobras), referentes aos ciclos 2011 a 2014, visto que cada ciclo de fiscalização subsidia o Parlamento na decisão acerca do bloqueio ou liberação dos recursos necessários para a execução desses empreendimentos na próxima Lei Orçamentária Anual.

Para fins de facilitação da consulta, apresenta-se a seguir os endereços da Câmara dos Deputados onde estão localizados os relatórios encaminhados pelo Tribunal de Cotnas da União por ciclo Fiscobras:

Fiscobras $2011-$

http://www.camara.gov.br/internet/comissao/index/mista/orca/orcamento/OR2012/fiscobra s2011_sintetico/Index.html

Fiscobras $2012-$

http://www.camara.gov.br/internet/comissao/index/mista/orca/orcamento/OR2013/Fiscobr as2012/anexo2/index.html

Fiscobras $2013-$

http://www.camara.gov.br/internet/comissao/index/mista/orca/orcamento/OR2014/Fiscobr as2013/anexo2/index.html

\footnotetext{
2 Ciclo PDCA (do inglês: PLAN - DO - ACT - CHECK, é um método iterativo de gestão de quatro
} passos, utilizado para o controle e melhoria contínua de processos e produtos. 
Fiscobras $2014-$

http://www.camara.gov.br/internet/comissao/index/mista/orca/orcamento/OR2015/Fiscobr as2014/anexo/index.html

Na seção "pesquisa" no endereço eletrônico institucional do Tribunal de Contas da União foi realizada levantamento dos acórdãos deliberados em função dos relatórios do Fiscobras, referentes aos anos de 2011, 2012, 2013 e 2014.

Importa destacar que as fiscalizações realizadas pelo Tribunal de Contas da União envolvem as licitações anteriormente levantadas, visto que todos os órgãos e entidades do Poder Executivo Federal são jurisdicionados ao TCU.

O conjunto de relatórios e acórdãos foram sistematizados na forma de Tabelas de modo a facilitar a estruturação dos dados e assim permitir a identificação dos empreendimentos e em quais ocorreram fiscalizações em licitações realizadas na modalidade contratação integrada, conforme segue.

Primeiramente foi efetuada a quantificação do total de relatórios de fiscalização enviados pelo TCU ao Congresso por acórdão consolidador por ciclo de fiscalização e para cada ciclo o total de relatórios envolvendo o regime de contratação integrada, conforme Tabela 3.2.

Tabela 3.2 - Ciclo Fiscobras 2011 até 2014

\begin{tabular}{c|c|c|c}
\hline $\begin{array}{c}\text { Ciclo } \\
\text { Fiscobras }\end{array}$ & Acórdão consolidador & $\begin{array}{c}\text { Quantidade } \\
\text { de } \\
\text { Fiscalizações }\end{array}$ & $\begin{array}{c}\text { Quantidade de } \\
\text { Fiscalizações } \\
\text { envolvendo a } \\
\text { Contratação } \\
\text { Integrada }\end{array}$ \\
\hline 2011 & & & \\
\hline$\ldots$ & TOTAL & $\sum$ & $\sum$ \\
\hline
\end{tabular}

Fonte: Autor.

Em seguida, apenas para fins de identificação, os relatórios que envolveram fiscalizações de licitações na modalidade contratação integrada foram identificados e apresentados de acordo com o ciclo Fiscobras relacionado. Posteriormente, os relatórios foram agrupados por empreendimento fiscalizado e por Órgão/Entidade, conforme Tabela 3.3. 
Tabela 3.3 - Relatórios por empreendimentos e por Órgão/Entidade

\begin{tabular}{c|l|l|l|l}
\hline $\mathbf{N}$ & \multicolumn{1}{|c|}{ Referência ao Empreendimento } & $\begin{array}{c}\text { Número de } \\
\text { relatórios }\end{array}$ & \multicolumn{2}{c}{ Relatório vinculado } \\
\hline \multicolumn{1}{l|}{ Órgão/Entidade A } & & \\
\hline 1 & Empreendimento 1 & & \\
\hline 2 & Empreendimento 2 & & \\
\hline$\cdots$ & & & \\
\hline Órgão/Entidade B & & \\
\hline $\mathrm{n}$ & Empreendimento n & & \\
\hline & TOTAL & & \\
\hline
\end{tabular}

Fonte: Autor.

A próxima Tabela correlaciona respectivamente a quantidade de constatações e os acórdãos por relatório e por empreendimento, Tabela 3.4.

Tabela 3.4 - Quantidade de constatações e os acórdãos por relatório e por empreendimento

\begin{tabular}{|c|c|c|c|c|}
\hline $\mathbf{N}$ & Referência ao Empreendimento & $\begin{array}{l}\text { Número de } \\
\text { constatações }\end{array}$ & $\begin{array}{l}\text { Relatório } \\
\text { vinculado }\end{array}$ & $\begin{array}{c}\text { Acórdão } \\
\text { vinculado }\end{array}$ \\
\hline \multicolumn{5}{|c|}{ Órgão/Entidade A } \\
\hline 1 & Empreendimento 1 & & & \\
\hline 2 & Empreendimento 2 & & & \\
\hline \multicolumn{5}{|c|}{$\cdots$} \\
\hline \multicolumn{5}{|c|}{ Órgão/Entidade B } \\
\hline \multirow[t]{2}{*}{$\mathrm{n}$} & Empreendimento $\mathrm{n}$ & & & \\
\hline & TOTAL & $\sum$ & - & \\
\hline
\end{tabular}

Fonte: Autor.

Em síntese, as Tabelas apresentam a totalidade de fiscalizações em empreendimentos na modalidade contratação integrada encaminhados pelo TCU ao Congresso Nacional no âmbito do Programa Fiscobras, ciclos 2011 até 2014, por órgão/entidade contratante, por empreendimento, por relatório de fiscalização, por constatação e por acordão. 


\subsection{ETAPA 2 - FÓRUM DE DEBATES SOBRE RISCOS}

A partir dos levantamentos realizados foi identificado que não havia uma uniformidade, no tocante ao tema riscos, entre os diversos órgãos que licitaram empreendimentos na modalidade contratação integrada.

Assim, surgiu a necessidade da realização de um evento técnico-científico dedicado exclusivamente para debater dialeticamente o tema gerando dessa discussão informações qualitativas para enriquecer a pesquisa.

Nesse contexto foi realizado em 2014 o $1^{\circ}$ Fórum da Universidade de Brasília de debate sobre Riscos em Obras Públicas, que teve o propósito de discutir a amplitude e relevância do tema riscos como elemento central nesse novo panorama de obras públicas.

A formatação do evento foi estruturada com base nos levantamentos realizados de forma a fomentar discussões sobre as vantagens e desvantagens das recentes modelagens de risco, a partir dos fundamentos teóricos e de acordo com as experiências e perspectivas de cada setor, visto que estavam reunidos pesquisadores, técnicos representando inúmeras instituições de diversos setores governamentais e a iniciativa privada.

Os aspectos mais destacados envolveram a metodologia de gerenciamento de riscos desenvolvida para obras rodoviárias e questões referentes ao progresso das obras pelo regime de contratação integrada. Destaca-se que o evento teve como premissa reunir ao longo de todo o dia, expressivo corpo técnico especializado em obras públicas de diversos setores governamentais; bem como permitir levantar informações para subsidiar esta pesquisa de mestrado sobre o tema de gerenciamento de riscos.

Ao todo foram realizadas duas palestras principais e duas mesas-redondas. As palestras abordaram os temas Gestão de Projetos e Riscos em Empreendimentos de Engenharia e Cálculo de contingências na orçamentação de obras públicas utilizando conceitos da AACE e Simulações de Monte Carlo.

As mesas-redondas abordaram os seguintes temas i) Novos desafios aos contratos de seguros e a análise quantitativa de riscos - aplicação nas contratações integradas de obras públicas e ii) Riscos em Obras Públicas: práticas, investimentos e perspectivas, especificamente no que tange ii.1) a alocação de riscos no projeto do Trem de Alta 
Velocidade e investimentos em contratações integradas do setor de transportes e ii.2) a perspectiva da contratação integrada de obras em aeroportos.

Para contribuir com a continuidade da discussão, foi elaborado um artigo técnico que descreveu didaticamente cada assunto abordado por meio de uma pesquisa exploratória dos materiais resultantes do encontro, apresentando as conclusões finais sobre a realização do evento e a percepção do domínio do assunto entre os participantes.

Em síntese, foi realizada uma análise acerca da compreensão do tema gestão de riscos pelos órgãos tendo como referência os certames que foram realizados e a corresponde relação dos mesmos com o conjunto de inovações legislativas trazidas pelo RDC para a contratação integrada.

\subsection{ETAPA 3 - MATRIZES DE AVALIAÇÃO DO NÍVEL DE MATURIDADE}

A partir da correlação entre as referências constantes do arcabouço jurídico brasileiro, o levantamento de licitações homologadas na modalidade de contratação integrada até 2014 e os resultados obtidos do Fórum, foi possível realizar uma avaliação sobre os certames efetuados nesta modalidade tendo como referência o alinhamento da prática observada com o arcabouço jurídico.

A avaliação dos certames supracitada é complementada ao final por uma avaliação das metodologias de precificação de riscos instituídas no âmbito da Administração Pública Federal.

Reforçando questão anteriormente apresentada, importa ressaltar que as três inovações legislativas e uma jurisprudencial conferidas aos gestores responsáveis por licitações na modalidade contratação integrada dizem respeito a 3 fases de gerenciamento de riscos, conforme segue:

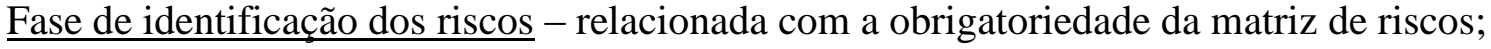

Fase de análise quantitativa dos riscos - relacionada com a possibilidade de ser considerada taxa de risco compatível com o objeto da licitação e as contingências atribuídas ao contratado; 
Fase de planejamento de respostas aos riscos - relacionadas com as duas estratégias de alocação de risco, o seguro e as garantias.

Destaca-se também que, com exceção da obrigatoriedade da matriz de riscos, todas as demais inovações legislativas facultam aos gestores liberdade quanto ao modo de realização, dado que há amplas formas de atuação compatíveis com as condições de mercado e a precificação do risco é uma possibilidade discricionária condicionada à oportunidade e conveniência administrativa.

A partir do levantamento de licitações realizadas na modalidade contratação integrada observou-se que nem todos os órgãos estavam empregando a totalidade do conjunto de inovações legislativas nos certames.

Uma vez que de acordo com a revisão bibliográfica as inovações descritas compõem 3 fases de um único processo de gerenciamento de riscos, foram construídas duas métricas de avaliação do nível de maturidade por cenários, a partir da análise e discussão dos levantamentos realizados durante o Fórum e elaboração de duas matrizes de avaliação do nível de maturidade tendo como referência os principais marcos legais e jurisprudenciais sobre o tema gerenciamento de riscos instituídos no âmbito da legislação do RDC.

O modelo de maturidade proposto difere de outros modelos estruturados, como por exemplo o modelo Capability Maturity Model (CMM), pela característica da abordagem, dado que os parâmetros legais e jurisprudenciais que se correlacionam com o tema gerenciamento de riscos são a base para a formulação das duas funções maturidade construídas:

Maturidade da identificação e análise quantitativa de riscos $\quad=\mathrm{f}$ (matriz de riscos, precificação de riscos)

Maturidade do planejamento de respostas aos riscos $=\mathrm{f}$ (condições de seguros, condições de garantias)

A primeira métrica corresponde a avaliação de maturidade em relação às fases de identificação e análise quantitativa de riscos, enquanto que a segunda corresponde a avaliação de maturidade em relação à fase de planejamento de respostas aos riscos, conforme a seguir descritas: 
Matriz de avaliação do nível de maturidade em relação às fases de identificação e análise quantitativa de riscos

A métrica foi estabelecida a partir do marco legal do Decreto $n^{\circ}$ 8.080, de 20/8/2013 e do marco jurisprudencial do Acórdão 1.510/2013-TCU-Plenário, de 19/6/2013.

I. Eixo das ordenadas: Decreto $n^{\circ}$ 8.080, de 20/8/2013, que possibilitou a regulamentação da taxa de risco (reserva de contingência) nas contratações integradas;

O marco legal possibilita o estabelecimento de dois possíveis cenários, um que se caracteriza pela realização de licitações sem precificação de risco e o outro com precificação de risco (ou reserva de contingência).

II. Eixo das coordenadas: Acórdão 1.510/2013-TCU-Plenário, de 19/6/2013, que se manifestou pela obrigatoriedade da matriz de risco no caso da contratação integrada.

O marco jurisprudencial possibilita o estabelecimento de dois possíveis cenários, um que se caracteriza pela realização de certames sem alocação de riscos (matriz de riscos) e o outro com alocação de risco.

Assim, a partir da conjunção da métrica legal com a métrica jurisprudencial foram estabelecidos quatro cenários de maturidade possíveis em relação à gestão de riscos no âmbito da contratação integrada:

a) Cenário I - maturidade inicial, onde o risco não é alocado nem precificado;

b) Cenário II - maturidade intermediária, onde o risco é alocado mas não é precificado;

c) Cenário III - adequada maturidade, onde o risco é alocado e precificado;

d) Cenário IV - inadequado, onde o risco não é alocado, contudo é precificado. Ressalta-se que este cenário é hipotético, pois não é possível precificar o risco sem alocá-lo antes.

A estrutura dessa matriz é apresentada na Figura 3.2. 


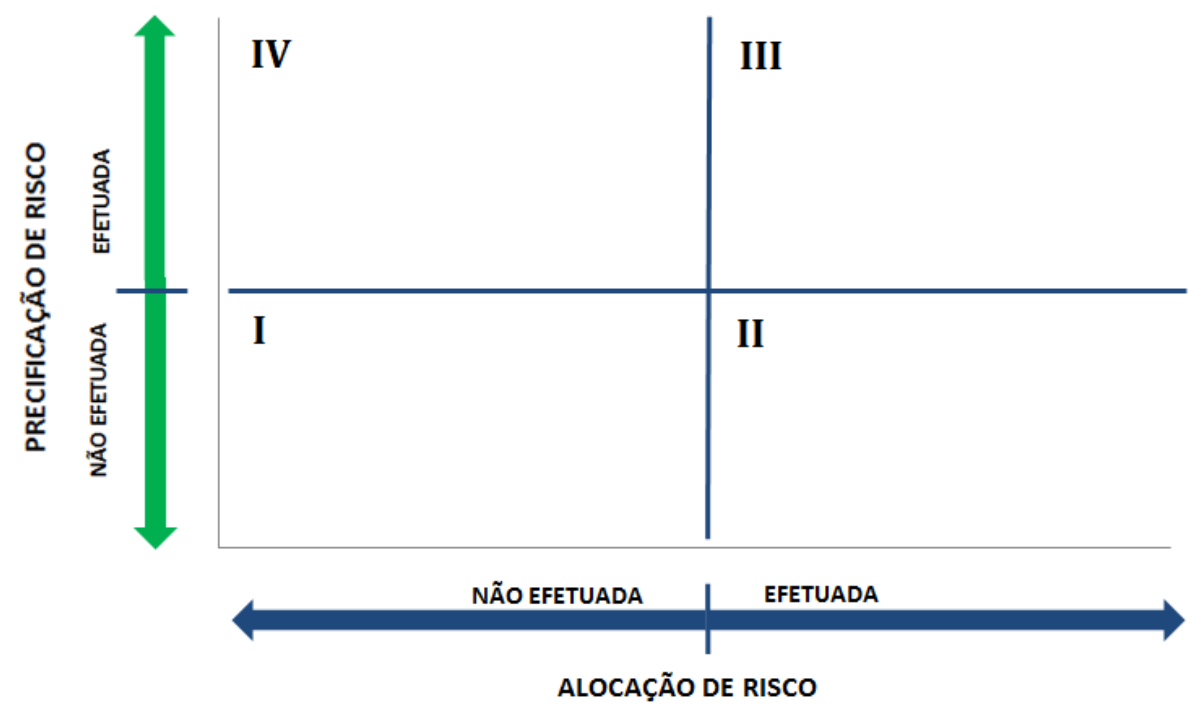

Figura 3.2 - Cenários de Maturidade em relação as fases de identificação e análise quantitativa de riscos.

Fonte: Autor.

Esta matriz apresenta a dimensão da maturidade dos órgãos em relação à compreensão da importância do processo de gerenciamento de riscos, visto que conforme o Guia PMBOK (2013) avançar um projeto sem focar o gerenciamento dos riscos de forma proativa pode causar mais problemas, surgidos em virtude de ameaças não gerenciadas.

Matriz de avaliação do nível de maturidade em relação à fase de planejamento de respostas $\underline{\operatorname{aos} \text { riscos }}$

A métrica foi estabelecida a partir do marco legal da Lei ${ }^{\circ} 12.462$, em 04/08/2011 e da Medida Provisória ${ }^{\circ}$ 630, de 24/12/2013, posteriormente convertida na Lei $\mathrm{n}^{\circ} 12.980$, de $28 / 5 / 2014$.

III. Eixo das ordenadas: Lei $\mathrm{n}^{\circ} 12.462$, em 04/08/2011, que trouxe a diretriz para utilizar condições de seguros compatíveis com as condições de mercado;

O marco legal possibilita o estabelecimento de dois possíveis cenários, um que se caracteriza pela realização de licitações com condições de seguro compatíveis com as condições de mercado, em especial exigências de apólices de seguro risco de engenharia e o outro sem a previsão desta exigência. 
IV. Eixo das coordenadas: Medida Provisória n 630, de 24/12/2013, posteriormente convertida na Lei $n^{\circ} 12.980$, de 28/5/2014, que trouxe a diretriz para utilizar condições de garantias compatíveis com as condições de mercado.

O marco legal possibilita o estabelecimento de dois possíveis cenários, um que se caracteriza pela realização de licitações com condições de garantias compatíveis com as condições de mercado, em especial percentuais de garantia maiores que os estabelecidos na Lei $\mathrm{n}^{\circ} 8.666 / 93$ e o outro que não se vale de percentuais de garantias maiores.

Assim, a partir da conjunção das métricas legais sobre condições de seguros e garantias foram estabelecidos quatro cenários de maturidade possíveis em relação às estratégias de alocação de riscos no âmbito da contratação integrada:

a) Cenário I - maturidade inicial, em que não são adotadas condições de seguros e garantias compatíveis com as condições de mercado;

b) Cenário II - maturidade intermediária, onde são adotadas apenas condições de seguros compatíveis com as condições de mercado;

c) Cenário III - adequada maturidade, onde são adotadas condições de seguros e garantias compatíveis com as condições de mercado;

d) Cenário IV - maturidade intermediária, onde são adotadas apenas condições de garantias compatíveis com as condições de mercado.

A estrutura dessa matriz é apresentada na Figura 3.3. 


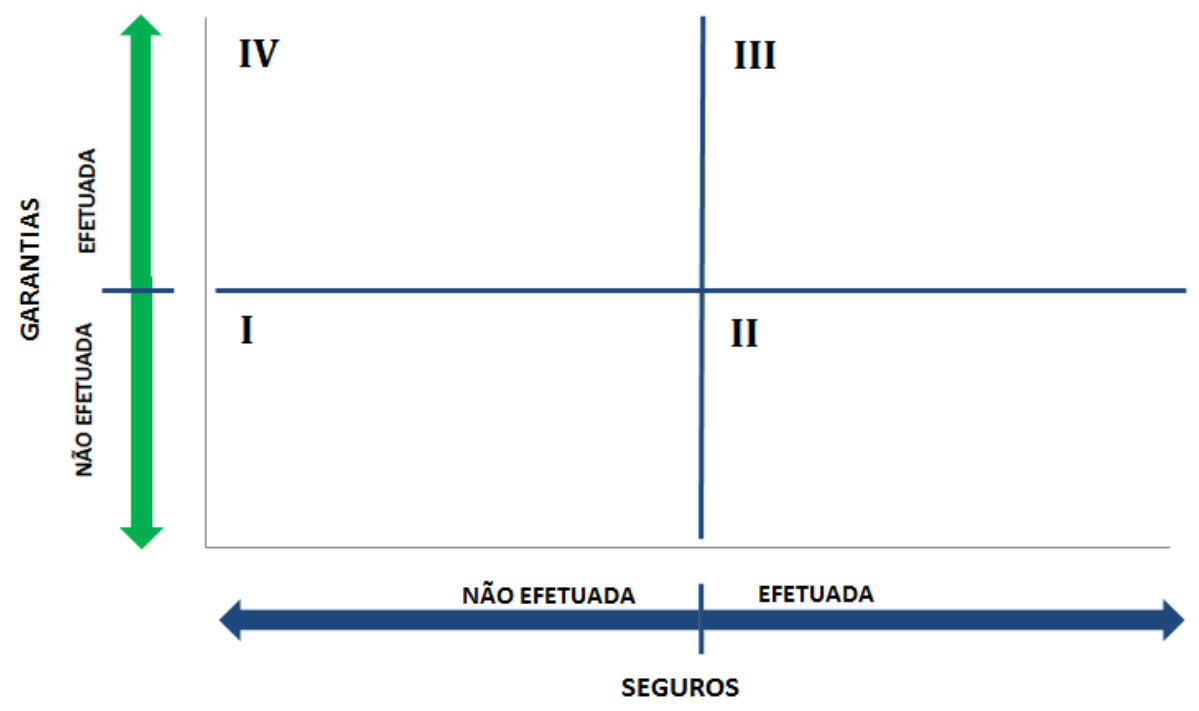

Figura 3.3 - Cenários de Maturidade em relação à fase de planejamento de respostas aos riscos.

Fonte: Autor.

Esta matriz apresenta a dimensão da maturidade dos órgãos em relação às estratégias de resposta perante o risco, relacionadas à transferência de riscos negativos por meio de seguros e garantias.

Os cenários de maturidade inicial (Cenário I) e maturidade intermediária (Cenários II e IV) expõem a Administração em caso de caracterização de sinistros não ser devidamente ressarcida, visto a limitação dos percentuais.

As análises realizadas possibilitaram uma avaliação do panorama atualizado do estágio em que se encontram os principais órgãos e entidades federais contratantes de obras públicas que utilizaram a modalidade de execução contratação integrada no âmbito do RDC, até o momento da pesquisa.

Posto isto, o referido panorama é complementado por uma avaliação das metodologias de precificação de riscos instituídas no âmbito da Administração Pública Federal, tendo como referência cada um dos seis processos (ou fases) de gerenciamento de risco preconizados no Guia PMBOK (2013).

Assim, para cada um dos processos de gerenciamento de riscos foi definida, de acordo com os insumos oriundos das fases anteriores, uma questão estratégica central relevante aderente a realidade da Administração Pública Federal nacional que possibilitasse a 
construção de uma diretriz exequível e de elevada possibilidade de impactar positivamente os resultados.

Ademais, conforme a seguir observado, a questão estratégica central pode contemplar subquestões vinculadas à mesma. As subquestões são desdobramentos da questão maior, formuladas de forma a trazer elementos para responder cada questão estratégica central.

1. Planejamento do gerenciamento dos riscos - A metodologia instituiu um plano de gerenciamento dos riscos? Em caso positivo, o plano aborda de forma completa os seguintes aspectos (Metodologia; Papéis e responsabilidades; Orçamentação; Prazos; Categorias de risco; Definições de probabilidade e impacto de riscos; Matriz de probabilidade e impacto; Revisão das tolerâncias das partes interessadas; Formatos de relatórios; e Forma de acompanhamento)?

2. Identificação dos riscos $-\mathrm{O}$ processo de categorização dos riscos que possibilitou a montagem da matriz de riscos aborda os seguintes tipos de riscos: sistêmicos, específicos do projeto e secundários?

3. Realização da análise qualitativa dos riscos - Os riscos foram identificados de acordo com a magnitude do efeito no custo, conforme o nível de maturidade do orçamento?

4. Realização da análise quantitativa dos riscos - A metodologia instituída apresenta fundamentação para os níveis de apetite ao risco e função densidade de probabilidade adotados?

5. Planejamento das respostas aos riscos - A metodologia contempla no planejamento de respostas aos riscos as diversas estratégias de resposta ao risco?

6. Controle dos riscos - A metodologia prevê processos específicos de avaliação da eficiência do processo de riscos, como parte integrante do plano de gerenciamento de riscos? Em caso positivo, as técnicas a serem utilizadas foram?

\subsection{ETAPA 4 - ANÁLISES}

Nessa etapa são realizadas análises da prática observada nos empreendimentos licitados pelos órgãos e entidades do Poder Executivo Federal que optaram por adotar o RDC, em sua modalidade de contratação integrada, sobre uma perspectiva gerencial tendo como 
referência o estágio de maturidade e as fiscalizações e deliberações do Tribunal de Contas da União em relação aos principais aspectos levantados na revisão bibliográfica.

Após o levantamento da totalidade de fiscalizações em empreendimentos na modalidade contratação integrada encaminhados pelo TCU ao Congresso Nacional no âmbito do Programa Fiscobras, ciclos 2011 até 2014, foram realizadas duas sistematizações dessa base amostral, uma sobre as questões de auditoria e outra sobre as constatações, ambas tendo como referência as 3 fases que integram o processo de contratação de um empreendimento público definidas conforme Mendes (2013), de modo a possibilitar a avaliação dos temas gestão de riscos e gestão de seguros e garantias.

A sistematização das questões de auditoria por fase do processo de contratação de um empreendimento público visa avaliar qual a ênfase da fiscalização e verificar se há correspondência das mesmas com os tipos de constatações identificadas.

Assim, as questões de auditoria foram listadas e correlacionadas por empreendimento, conforme Tabela 3.5, marcando-se em cada empreendimento o número de vezes que a questão de auditoria se repetiu.

Tabela 3.5 - Relação da quantidade de questões de auditoria por empreendimento

\begin{tabular}{c|c|c|c|c|c}
\hline \multirow{2}{*}{ N } & \multirow{2}{*}{ Questão de Auditoria } & \multicolumn{3}{|c}{ Empreendimento } & TOTAL \\
\cline { 3 - 6 } & & Empreendimento 1 & Empreendimento 2 & $\ldots$ & \\
\cline { 3 - 6 } & & \multicolumn{2}{|c|}{ Quantidade de questões de auditoria } & $\ldots$ & $\sum$ \\
\hline I & \multirow{2}{*}{ Primeira questão } & & & $\ldots$ & $\ldots$ \\
\hline N & N-ésima questão & $\sum$ & $\sum$ & $\ldots$ & $\sum$ \\
\hline
\end{tabular}

Fonte: Autor.

No Quadro 3.2 as questões de auditoria são apresentadas na ordem da questão mais recorrente para a menos recorrente. 


\begin{tabular}{|l|}
\hline \multicolumn{1}{|c|}{ Questão de Auditoria } \\
\hline Anteprojeto \\
\hline Licitação \\
\hline Fiscalização \\
\hline
\end{tabular}

Quadro 3.2 - questões de auditoria por fase de contratação

Fonte: Autor.

Em sequência, o conjunto de questões de auditoria é apresentado pela correspondente fase de contratação, conforme Tabela 3.6.

Tal forma de apresentação visa explicitar no conjunto de questões de auditorias, quais são àquelas que se referem a aspectos relacionados à gestão de riscos ou à gestão de seguros e garantias.

No que tange especificamente as constatações, foi efetuada a sua categorização por ocorrência de acordo com a fase do empreendimento - a categorização das constatações teve como referência as 3 fases que integram o processo de contratação de um empreendimento público definidas por Mendes (2013), conforme Tabela 3.6.

Tabela 3.6 - Percentual das constatações por fase de contratação

\begin{tabular}{l|c|c}
\hline \multicolumn{1}{c|}{ Fase de Contratação } & $\begin{array}{c}\text { Quantidade de } \\
\text { Constatações }\end{array}$ & Percentual \\
\hline Anteprojeto de Engenharia & & \\
\hline Processo Licitatório & & \\
\hline Fiscalização & $\sum$ & $\Sigma$ \\
\hline TOTAL & Foñ Autor & \\
\hline
\end{tabular}

Fonte: Autor. 
Essa sistematização teve como referência avaliar a correspondência entre o percentual de constatações com as questões de auditoria.

Posteriormente, para fins de registro, cada conjunto de constatações foi apresentado por fase de contratação, uma vez que o agrupamento facilita a observação de cada uma das constatações.

No que tange às constatações referentes ao Anteprojeto de Engenharia, o agrupamento permite explicitar qual constatação aborda o tema gestão de riscos e gestão de seguros e garantias.

Em sequência, é feita a correlação entre Relatórios de Fiscalização e Acórdãos que abordam o tema gestão de riscos e gestão de seguros e garantias, conforme Tabela 3.7.

Tabela 3.7 - Relatórios de Fiscalização e Acórdãos que abordam o tema gestão de riscos e seguros e garantias

\begin{tabular}{l|l|l|l}
\hline $\begin{array}{c}\text { Referência do } \\
\text { Empreendimento }\end{array}$ & $\begin{array}{c}\text { Gestão } \\
\text { de } \\
\text { Riscos }\end{array}$ & $\begin{array}{c}\text { Gestão de } \\
\text { Seguros e } \\
\text { Garantias }\end{array}$ & Relatórios de Fiscalização e Acórdãos de referência \\
\hline Órgão/Entidade A & & \\
\hline Empreendimento 1 & & & \\
\hline$\ldots$ & & & \\
\hline Órgão/Entidade & & & \\
\hline Empreendimento n & & & \\
\hline
\end{tabular}

Fonte: Autor.

Todas as sistematizações efetuadas objetivaram detalhar a forma de estruturação dos relatórios de fiscalização e verificar a correspondência das constatações com as principais inovações do regime de contratação integrada em relação aos temas gestão de riscos e gestão de seguros e garantias.

Ao final da etapa de análise foram realizadas considerações de caráter diagnóstico sobre o que foi observado no processo de contratação integrada brasileiro à luz do tema gerenciamento de riscos. 


\subsection{ETAPA 5 - DIRETRIZES PARA O GERENCIAMENTO DE RISCOS}

Nessa fase, os resultados das análises foram registrados tendo como referência a percepção de domínio institucional dos assuntos de acordo os fundamentos teóricos, legais e jurisprudenciais sobre gestão de riscos e gestão de seguros e garantias.

As diretrizes para o gerenciamento de riscos são o resultado da consolidação dos principais aspectos observados nas etapas anteriores.

A partir do arcabouço de questões definidas com base na revisão bibliográfica e no Fórum de Debates sobre Riscos em Obras Públicas foram efetuadas avaliações nas licitações levantadas que resultaram numa avaliação do nível de maturidade dos órgãos do Poder Executivo Federal que realizam certames na contratação integrada.

Em sequência foram realizadas avaliações nas metodologias de precificação de riscos instituídas pelos órgãos supracitados, tendo como referência cada um dos seis processos (ou fases) de gerenciamento de risco preconizados no Guia PMBOK (2013).

Os resultados obtidos das avaliações das metodologias foram determinantes para a formulação das diretrizes tendo em vista que a adequabilidade das mesmas é função da sua aplicabilidade.

As diretrizes tem o propósito de eliminar/mitigar/reduzir as disfunções estruturais da gestão de riscos identificadas nas fases anteriores da pesquisa, em especial àquelas relacionadas às questões estratégicas formuladas para a avaliação das metodologias.

As diretrizes são construídas de modo a evidenciar e explicitar "o que" deve ser aperfeiçoado ou corrigido e não "como" fazer. Ademais, as diretrizes não abordam mero cumprimento de normativos ou observância de legislação.

Complementarmente, foram incorporadas na análise aspectos das fiscalizações e consequentes recomendações do Tribunal de Contas da União, visto que as mesmas se constituem em importante referência jurisprudencial de amparo aos gestores federais.

Os temas critérios de julgamento, grau de competição de um certame, nível de precisão e sigilo do orçamento paradigma da Administração presentes na revisão da literatura internacional foram incorporados às diretrizes, tendo em vista que tais aspectos são de 
grande significância para o desempenho das contratações e não foram observados na rotina de licitação dos órgãos que tiveram certames avaliados.

Nesse contexto, as diretrizes englobam um conjunto de dez temas de significativa relevância para o processo de gerenciamento de riscos, conforme a seguir apresentado:

I. Critérios de julgamento

II. Nível de precisão da estimativa de custo paradigma da Administração

III. Grau de competição de um certame

IV. Sigilo do valor da estimativa de custo paradigma da Administração

V. Planejamento do gerenciamento dos riscos

VI. Identificação dos riscos

VII. Realização da análise qualitativa dos riscos

VIII. Realização da análise quantitativa dos riscos

IX. Planejamento das respostas aos riscos

X. Controle dos riscos

Para cada tema é apresentado uma diretriz dirigida aos gestores responsáveis pelas licitações na modalidade contratação integrada, sendo complementada por considerações sobre o seu fundamento e a referência bibliográfica que suporta o estabelecimento da diretriz.

As diretrizes são referências gerais para o gerenciamento de riscos que buscam fomentar o aprimoramento da gestão pública e contribuir com os gestores seja por meio de boas práticas ou alertas, devendo as mesmas serem adaptadas de acordo com a prática gerencial e nível de maturidade específico de cada órgão.

Registra-se também que as diretrizes não representam uma lista exaustiva de ações a serem tomadas e não representam uma ação de caráter obrigatório a ser tomado. 


\section{RESULTADOS}

Neste capítulo são apresentados os resultados das avaliações estruturados de acordo com as etapas do método de pesquisa empregado.

\subsection{LEVANTAMENTOS}

Os resultados da fase de levantamentos contemplam o levantamento de licitações homologadas na modalidade contratação integrada até 2014 e o levantamento das fiscalizações realizadas no âmbito do Fiscobras, ciclos 2011 até 2014, pelo Tribunal de Contas da União na modalidade de contratação integrada.

\subsubsection{Resultado do levantamento de licitações homologadas na modalidade de} contratação integrada até 2014

Foram pesquisados um total de 10 órgãos/entidades em que é possível enquadrar os casos e tipologias de obras e serviços de engenharia permitidos nos termos das sucessivas ampliações do RDC.

O levantamento foi efetuado a partir de quatro referenciais (referencial de sucesso, temporal, político-administrativo e locacional) e desse conjunto, em apenas 5 órgãos foram identificadas licitações homologadas na contratação integrada.

Em sequência, foi realizado o enquadramento dos certames anteriormente identificados em relação as três inovações legislativas e uma jurisprudencial, descritas na metodologia, relacionadas ao gerenciamento de riscos.

A tabela 4.1 apresenta o quantitativo de certames que foram homologados na modalidade de contratação integrada até 2014 por órgão/entidade. O detalhamento de cada um dos 50 certames levantados está no Apêndice IV. 
Tabela 4.1 - Quantitativo de licitações homologadas na modalidade contratação integrada

\begin{tabular}{c|c|c|c|c|c}
\hline $\begin{array}{c}\text { Órgão / } \\
\text { Entidade }\end{array}$ & $\begin{array}{c}\text { Quantitativo de } \\
\text { licitações homologadas } \\
\text { na modalidade } \\
\text { Contratação Integrada } \\
\text { (referência: Dez/2014) }\end{array}$ & $\begin{array}{c}\text { Matriz de } \\
\text { Risco }\end{array}$ & $\begin{array}{c}\text { Precificação do } \\
\text { Risco (Reserva } \\
\text { de } \\
\text { Contingência) }\end{array}$ & $\begin{array}{c}\text { Condições de } \\
\text { seguros } \\
\text { compatíveis } \\
\text { com o } \\
\text { mercado }\end{array}$ & $\begin{array}{c}\text { Condições de } \\
\text { garantias } \\
\text { compatíveis } \\
\text { com o } \\
\text { mercado }\end{array}$ \\
\hline DNIT - Sede & 42 & 22 & 13 & 42 & 25 \\
\hline VALEC & 5 & 1 & 0 & 5 & 0 \\
\hline $\begin{array}{c}\text { Infraero } \\
\text { Ministério } \\
\text { da }\end{array}$ & 1 & 0 & 0 & 1 & 0 \\
$\begin{array}{c}\text { Integração } \\
\text { Nacional }\end{array}$ & 1 & 1 & 0 & 1 & 0 \\
\hline $\begin{array}{c}\text { Secretaria } \\
\text { de Portos }\end{array}$ & 1 & 1 & 0 & 0 & 0 \\
\hline TOTAL & $\mathbf{5 0}$ & $\mathbf{2 5}$ & $\mathbf{1 3}$ & $\mathbf{4 9}$ & $\mathbf{2 5}$ \\
\hline
\end{tabular}

Fonte: Autor.

Em síntese, de 2011 até 2014, foram homologadas 50 licitações na modalidade contratação integrada, sendo 42 no DNIT, ou 84\% desse total. A VALEC com 5 certames, ou $10 \%$, é o segundo órgão com maior número de contratações integradas homologadas. Os três outros, Infraero, Ministério da Integração Nacional e Secretaria de Portos, tem apenas um certame homologado, cada um.

Do conjunto de certames do DNIT, destaca-se que a licitação para as obras de duplicação da BR-381/MG (Edital 165/2013, publicado em 28 de março de 2013) é o seu ponto de inflexão, uma vez que esta licitação foi a pioneira no DNIT, e também no Brasil, na previsão da matriz de risco e precificação de risco. A partir desse certame, todas as demais licitações dessa autarquia na modalidade contratação integrada passaram a incluir a matriz de riscos.

No que tange a precificação de risco do DNIT, em apenas 13 dos 22 certames após a licitação da BR-381/MG, com este incluso, foi calculado a reserva de contingência. Destaca-se que os demais não estão inclusos na hipótese de aplicação da análise de risco, prevista no $\S 1^{\circ}$ do Art. $2^{\circ}$ da Instrução de Serviço/DG $n^{\circ}$ 01, de 2/1/2014.

Cabe reforçar que todos os processos e documentações relacionados à análise de risco das licitações na modalidade de execução contratação integrada realizadas pelo DNIT são sigilosos. 
Em relação à VALEC, os quatro primeiros certames realizados não incluíram matriz de risco, sendo esta somente integrante do último certame realizado.

Em relação à Infraero, o único certame nessa modalidade ocorreu para as obras no Aeroporto Internacional Afonso Pena, em São José dos Pinhais/PR, antes do Acórdão ${ }^{\circ}$ 1.510/2013 - TCU - Plenário e não tem matriz de risco.

À titulo de informação, registra-se que a Infraero realizou dois outros certames na modalidade contratação integrada. Para o Terminal de Passageiros 3 (TPS 3) no Aeroporto Internacional Tancredo Neves, Confins/MG, a licitação foi deserta. Para o Terminal de Passageiros $n^{\circ} 2$ (TPS-2) do Aeroporto Internacional do Rio de Janeiro/Galeão - Antônio Carlos Jobim, ocorreu a concessão aeroporto e o certame deixou de integrar a amostra.

Em relação ao Ministério da Integração Nacional, em que pese a pasta ter instituído metodologia de riscos, até o final do ano de 2014, apenas um único certame realizado na modalidade contratação integrada foi homologado por esta pasta ministerial, RDC $\mathrm{n}^{\circ}$ 004/2013, contudo, foi realizado antes do estabelecimento da metodologia de riscos do Ministério da Integração, razão pela qual teve somente matriz de risco pois ocorreu após Acórdão ${ }^{\circ}$ 1.510/2013 - TCU - Plenário.

Em relação à Secretaria de Porto, apenas o certame para a Dragagem do Complexo Portuário do Rio de Janeiro foi homologada até 2014.

Em síntese, além de poucos certames realizados, a modalidade contratação integrada foi concentrada e efetivamente empregada no DNIT, visto que nos demais, sua utilização reúne um quantitativo pouco expressivo de certames homologados.

No que tange à previsão de um instrumento de alocação de risco, o ponto de inflexão foi Acórdão 1510/2013-TCU-Plenário que a tornou obrigatória.

Posto isto, tem-se que somente $50 \%$ dos certames realizados utilizaram matriz de riscos, ou seja, em outros $50 \%$, ou 25 certames, em termos numéricos, a licitação foi processada sem que houvesse sido realizada a primeira fase do processo de gerenciamento de riscos.

Em relação a fase de análise quantitativa de risco, tem-se que apenas em 13 certames homologados até 2014 foram empregados uma metodologia para precificação de risco. 
Esse conjunto, além de pouco significativo, ainda foi realizado por apenas um órgão, de modo que os únicos exemplos existentes do emprego da precificação de riscos na modalidade contratação integrada são todos afetos a tipologia de obras rodoviárias.

Outro fato que sobressai da análise é que o edital para as obras de duplicação da BR381/MG, o primeiro que envolveu precificação de riscos no Brasil, foi publicado em 28 de março de 2013, ao passo que a alteração legislativa que instituiu a atribuição de contingências ocorreu em 20 de agosto do mesmo ano, por meio do Decreto $\mathrm{n}^{\circ} 8.080$, ou seja, praticamente cinco meses após a publicação desse certame.

Com exceção do único certame homologado pela Secretaria de Portos, todos os outros 49 certames realizados utilizaram condições de seguros compatíveis com o mercado, ou seja, o seguro risco de engenharia.

Já em relação às condições de garantias, apenas o DNIT admitiu a exigência de garantias compatíveis com as de mercado.

Em síntese, quatro anos após a instituição do regime de execução contratação integrada no cenário nacional de obras públicas, foi possível verificar até o momento dessa pesquisa, dentre a documentação pública disponível para o crivo da sociedade, que o universo de licitações realizadas nesse regime é pequeno e concentrado no Departamento Nacional de Infraestrutura de Transportes - DNIT.

Em apenas 13 certames, ou 26\% das contratações integradas realizadas, o risco transferido para o contratado foi precificado para a justa remuneração, explicitando um paradoxo de compreensão do processo de gerenciamento de risco, já que reconhecidamente o anteprojeto de engenharia carrega em si uma imprecisão que acarreta a assunção de maiores riscos para o contratado.

Ademais, a prática brasileira de orçamentação se dá pela inclusão da reserva de contingência como percentual do BDI, tanto que o acórdão 2622/2013-TCU-Plenário definiu patamares referencias para aceitação do percentual de contingência.

Por outro lado, a legislação do RDC definiu que a contingência precificada no caso das contratações integradas não integra a parcela do BDI do orçamento estimado, visto que deve ser considerada apenas para efeito de análise de aceitabilidade das propostas ofertadas no processo licitatório. 


\subsubsection{Resultado do levantamento das fiscalizações realizadas no âmbito do Fiscobras pelo}

$\underline{\text { Tribunal de Contas da União na modalidade de contratação integrada }}$

Desde 2011, ano em que foi instituído o regime de contratação integrada (Lei $\mathrm{n}^{\circ}$ 12.462/2011) até o momento da pesquisa, o Tribunal de Contas da União concluiu quatro ciclos de fiscalização Fiscobras, de 2011 a 2014.

Nesses quatro ciclos o TCU, em cumprimento às suas atribuições legais, encaminhou ao Congresso Nacional um total de 668 Relatórios de Fiscalização. Desse total, foram identificados 28 Relatórios de Fiscalizações que abordaram empreendimentos que utilizaram o regime de contratação integrada, sendo 13 encaminhados no ciclo Fiscobras 2013 e 15 encaminhados no ciclo Fiscobras 2014.

Foi observado que não foram encaminhados relatórios de fiscalização ao Congresso sobre o tema contratação integrada nos ciclos de 2011 e 2012. Já o ciclo de 2015 ainda não foi concluído.

A tabela 4.2 apresenta o total de relatórios de fiscalização enviados pelo TCU ao Congresso por acórdão consolidador e por ciclo de fiscalização com destaque para a quantidade de relatórios envolvendo o regime de contratação integrada.

Tabela 4.2 - Ciclo Fiscobras 2011 até 2014

\begin{tabular}{c|c|c|c}
\hline $\begin{array}{c}\text { Ciclo } \\
\text { Fiscobras }\end{array}$ & Acórdão consolidador & $\begin{array}{c}\text { Quantidade } \\
\text { de } \\
\text { Fiscalizações }\end{array}$ & $\begin{array}{c}\text { Quantidade de } \\
\text { Fiscalizações } \\
\text { envolvendo a } \\
\text { Contratação } \\
\text { Integrada }\end{array}$ \\
\hline 2011 & Acórdão 2877/2011-TCU-Plenário & 230 & 0 \\
\hline 2012 & Acórdão 2928/2012-TCU-Plenário & 200 & 0 \\
\hline 2013 & Acórdão 2969/2013-TCU-Plenário & 136 & 13 \\
\hline 2014 & Acórdão 2981/2014-TCU-Plenário & 102 & 15 \\
\hline & TOTAL & $\mathbf{6 6 8}$ & $\mathbf{2 8}$ \\
\hline
\end{tabular}

Fonte: Autor.

No que tange ao ciclo Fiscobras de 2011, destaca-se que o TCU definiu a relação de empreendimentos a serem fiscalizados naquele ciclo em março do ano em referência, ao passo que a lei que instituiu o RDC, Lei ${ }^{\circ} 12.462$, foi somente promulgada em 4/8/2011. 
Assim, nesse ciclo não ocorreram fiscalizações abordando o regime de contratação integrada.

Contudo, destaca-se que dos 13 relatórios encaminhados ao Congresso no ciclo de 2013, oito decorreram de trabalhos iniciados em 2012, conforme explicitado no Quadro 4.1. Essa explicação se faz necessária para que não seja passada a falsa impressão de que os trabalhos de avaliação da contratação integrada somente se iniciaram em 2013.

Além das fiscalizações que compuseram o quantitativo de 28 relatórios encaminhados ao Congresso, destacam-se as seguintes fiscalizações que abordaram empreendimentos que utilizaram o regime de contratação integrada e que são mencionadas nos acórdãos consolidadores dos ciclos Fiscobras 2013 e 2014:

- Fiscobras 2013 - fiscalização temática no Programa Nacional de Reestruturação e Aquisição de Equipamentos para a Rede Escolar Pública de Educação Infantil (Proinfância), cuja responsabilidade de execução compete ao Fundo Nacional de Desenvolvimento da Educação (FNDE);

- $\quad$ Fiscobras 2014 - quatro fiscalizações relevantes efetuadas em licitações do DNIT provenientes de representações foram registradas nesse relatório consolidador. 


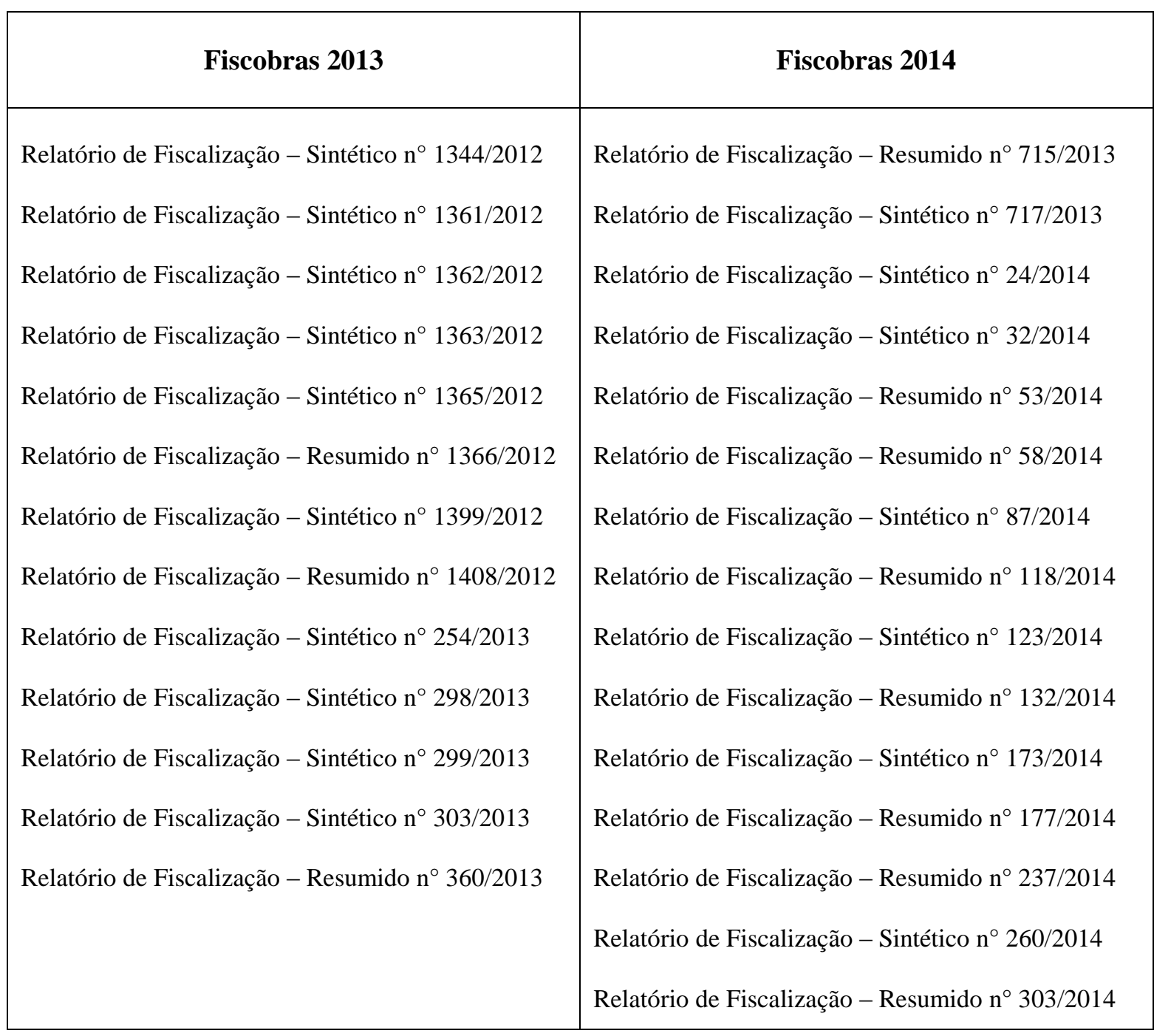

Quadro 4.1 - Relação dos Relatórios encaminhados ao Congresso Nacional nos ciclos Fiscobras de 2013 e 2014 referentes ao tema contratação integrada Fonte: Autor.

Fato análogo ao anteriormente apresentado ocorreu no ciclo Fiscobras 2014. Assim pelo exposto, considera-se mais adequado utilizar a referência do ano em que o trabalho foi iniciado ao invés da referência ao ano em que o relatório foi encaminhado ao Congresso.

Esses relatórios por sua vez foram agrupados em 18 empreendimentos, seja porque tiveram mais de um relatório por empreendimento, como foi o caso de duas obras rodoviárias que tiveram relatórios para cada lote (ou trecho) de rodovia, seja porque foram empreendimentos avaliados nos dois ciclos, como demonstrado na Tabela 4.3 a seguir. 
Tabela 4.3 - Relatórios por empreendimentos e por Órgão/Entidade

\begin{tabular}{|c|c|c|c|}
\hline $\mathbf{N}$ & Referência ao Empreendimento & $\begin{array}{l}\text { Número de } \\
\text { relatórios }\end{array}$ & Relatório vinculado \\
\hline \multicolumn{4}{|c|}{ DNIT } \\
\hline 1 & BR-101/PE - Anel Viário de Recife & 1 & Relatório de Fiscalização n 118/2014 \\
\hline 2 & BR-156/AP - Pavimentação & 1 & Relatório de Fiscalização n 58/2014 \\
\hline 3 & BR-163/MT - Pavimentação & 1 & Relatório de Fiscalização n 1408/2012 \\
\hline 4 & BR-163/PA - Pavimentação & 2 & $\begin{array}{l}\text { Relatório de Fiscalização n }{ }^{\circ} 1399 / 2012 \\
\text { Relatório de Fiscalização n } \\
\text { 24/2014 }\end{array}$ \\
\hline 5 & BR-174/MT - Pavimentação & 1 & Relatório de Fiscalização n $715 / 2013$ \\
\hline 6 & BR-316/AL - Pavimentação & 1 & Relatório de Fiscalização n 53/2014 \\
\hline 7 & BR-381/MG - Duplicação & 6 & 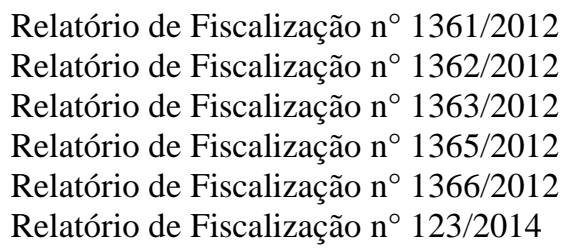 \\
\hline 8 & Programa BR-Legal - Sinalização Viária & 2 & $\begin{array}{l}\text { Relatório de Fiscalização n 298/2013 } \\
\text { Relatório de Fiscalização nº 299/2013 }\end{array}$ \\
\hline 9 & $\begin{array}{l}\text { Construção da } 2^{\text {a }} \text { Ponte sobre o Rio } \\
\text { Guaíba/RS }\end{array}$ & 1 & Relatório de Fiscalização n ${ }^{\circ} 717 / 2013$ \\
\hline 10 & $\begin{array}{l}\text { Derrocamento na Hidrovia do Rio } \\
\text { Tocantins/PA }\end{array}$ & 1 & Relatório de Fiscalização n ${ }^{\circ}$ 173/2014 \\
\hline 11 & Porto de Manaus/AM & 2 & $\begin{array}{l}\text { Relatório de Fiscalização n’ 303/2013 } \\
\text { Relatório de Fiscalização nº 32/2014 }\end{array}$ \\
\hline \multicolumn{4}{|c|}{ Infraero } \\
\hline 12 & TPS-3 do Aeroporto de Confins/MG & 1 & Relatório de Fiscalização n 254/2013 \\
\hline 13 & TPS do Aeroporto Afonso Pena/PR & 2 & $\begin{array}{l}\text { Relatório de Fiscalização n }{ }^{\circ} 1344 / 2012 \\
\text { Relatório de Fiscalização nº } \\
\text { 87/2014 }\end{array}$ \\
\hline \multicolumn{4}{|c|}{ Ministério da Integração Nacional } \\
\hline 14 & Ramal do Agreste/PE & 1 & Relatório de Fiscalização n 177/2014 \\
\hline 15 & Ramal do Entremontes/PE & 1 & Relatório de Fiscalização n 303/2014 \\
\hline \multicolumn{4}{|c|}{ Ministério da Saúde } \\
\hline 16 & Complexo Materno de Teresina/PI & 2 & $\begin{array}{l}\text { Relatório de Fiscalização n’ 360/2013 } \\
\text { Relatório de Fiscalização n }{ }^{\circ} \text { 237/2014 }\end{array}$ \\
\hline 17 & $\begin{array}{l}\text { UBS e UPAs - Unidades Básicas de } \\
\text { Saúde e Unidades de Pronto Atendimento }\end{array}$ & 1 & Relatório de Fiscalização n 260/2014 \\
\hline \multicolumn{4}{|c|}{ Secretaria de Portos } \\
\hline \multirow[t]{2}{*}{18} & Dragagem do Porto de Santos/SP & 1 & Relatório de Fiscalização n 132/2014 \\
\hline & TOTAL & 28 & \\
\hline
\end{tabular}

Fonte: Autor. 
Pode-se observar que o DNIT foi a instituição mais contemplada com quantidade de fiscalizações, perfazendo 11 ao total. A Infraero, o Ministério da Integração Nacional e o Ministério da Saúde, cada um, tiveram duas obras fiscalizadas. A Secretaria de Portos teve um empreendimento fiscalizado.

Em relação à BR-381/MG destaca-se que cinco relatórios são vinculados a cada um dos seguintes lotes fiscalizados em 2012: Lote 3.1, Lote 3.2, Lote 3.3, Lote 6 e Lote 8A. O sexto relatório está vinculado ao ciclo Fiscobras 2014, tendo como objetivo avaliar a conformidade e o desempenho da contratação integrada nos Lotes 3.1 e 6, uma vez um mesmo consórcio sagrou-se vencedor em ambos.

A fiscalização envolvendo o Programa Nacional de Segurança e Sinalização Rodoviária BR-Legal foi realizada somente no ciclo Fiscobras 2013, mas abrange dois relatórios, uma vez que um relatório refere-se a um lote do Programa em Rondônia e o outro a um lote no Acre.

Os demais empreendimentos com que contém dois relatórios devem ao fato de que foram fiscalizados em dois ciclos.

Sobre esse quantitativo de obras fiscalizadas observa-se que a seleção dos empreendimentos fiscalizados foi pautada em 5 fatores, conforme: i) o valor autorizado e o empenhado no exercício anterior e no exercício atual; ii) os projetos de grande vulto; iii) a regionalização do gasto; iv) o histórico de irregularidades pendentes obtido a partir de fiscalizações anteriores e a reincidência de irregularidades cometidas; e v) as obras com Indícios de Irregularidades Graves da Lei Orçamentária em vigor que não foram objeto de deliberação posterior do Tribunal de Contas da União pela regularidade.

No entanto, nenhuma avaliação sobre a adequabilidade da seleção de empreendimentos fiscalizados foi realizada, visto que os acórdãos que definiram a relação de fiscalizações por ciclo Fiscobras são sigilosos, conforme verificado em consulta à página eletrônica institucional do TCU:

- Acórdão 564/2011-TCU- Plenário - definiu a relação de fiscalizações que foram realizadas no ciclo Fiscobras 2011;

- Acórdão 2382/2011-TCU-Plenário - definiu a relação de fiscalizações que foram realizadas no ciclo Fiscobras 2012; 
- Acórdão 448/2013-TCU-Plenário - definiu a relação de fiscalizações que foram realizadas no ciclo Fiscobras 2013;

- Acórdão 3143/2013-TCU-Plenário - definiu a relação de fiscalizações que foram realizadas no ciclo Fiscobras 2014;

Quanto à constatações registradas nos 28 Relatórios, a Tabela 4.4 apresenta o quantitativo de constatações por relatório e por empreendimento. 
Tabela 4.4 - Quantidade de constatações por relatório e por empreendimento

\begin{tabular}{|c|c|c|c|}
\hline $\mathbf{N}$ & Referência ao Empreendimento & $\begin{array}{l}\text { Número de } \\
\text { constatações }\end{array}$ & Relatório vinculado \\
\hline \multicolumn{4}{|c|}{ DNIT } \\
\hline 1 & BR-101/PE - Anel Viário de Recife & 2 & Relatório de Fiscalização n $118 / 2014$ \\
\hline 2 & BR-156/AP - Pavimentação & 1 & Relatório de Fiscalização n 58/2014 \\
\hline 3 & BR-163/MT - Pavimentação & 1 & Relatório de Fiscalização n $1408 / 2012$ \\
\hline 4 & BR-163/PA - Pavimentação & $\begin{array}{l}1 \\
2\end{array}$ & $\begin{array}{l}\text { Relatório de Fiscalização n }{ }^{\circ} \text { 1399/2012 } \\
\text { Relatório de Fiscalização n } 24 / 2014\end{array}$ \\
\hline 5 & BR-174/MT - Pavimentação & 3 & Relatório de Fiscalização n $715 / 2013$ \\
\hline 6 & BR-316/AL - Pavimentação & 7 & Relatório de Fiscalização n 53/2014 \\
\hline 7 & BR-381/MG - Duplicação & $\begin{array}{l}1 \\
0 \\
0 \\
1 \\
1 \\
2\end{array}$ & 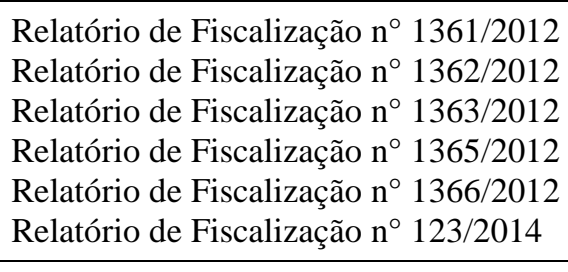 \\
\hline 8 & Programa BR-Legal - Sinalização Viária & $\begin{array}{l}5 \\
6\end{array}$ & $\begin{array}{l}\text { Relatório de Fiscalização n } 298 / 2013 \\
\text { Relatório de Fiscalização nº 299/2013 }\end{array}$ \\
\hline 9 & $\begin{array}{l}\text { Construção da } 2^{\text {a }} \text { Ponte sobre o Rio } \\
\text { Guaíba/RS }\end{array}$ & 3 & Relatório de Fiscalização n 717/2013 \\
\hline 10 & $\begin{array}{l}\text { Derrocamento na Hidrovia do Rio } \\
\text { Tocantins/PA }\end{array}$ & 1 & Relatório de Fiscalização n 173/2014 \\
\hline 11 & Porto de Manaus/AM & $\begin{array}{l}3 \\
5\end{array}$ & $\begin{array}{l}\text { Relatório de Fiscalização n } 303 / 2013 \\
\text { Relatório de Fiscalização n }{ }^{\circ} 32 / 2014\end{array}$ \\
\hline \multicolumn{4}{|c|}{ Infraero } \\
\hline 12 & TPS-3 do Aeroporto de Confins/MG & 1 & Relatório de Fiscalização n $254 / 2013$ \\
\hline 13 & TPS do Aeroporto Afonso Pena/PR & $\begin{array}{l}5 \\
1\end{array}$ & $\begin{array}{l}\text { Relatório de Fiscalização n }{ }^{\circ} 1344 / 2012 \\
\text { Relatório de Fiscalização nº } 87 / 2014\end{array}$ \\
\hline \multicolumn{4}{|c|}{ Ministério da Integração Nacional } \\
\hline 14 & Ramal do Agreste/PE & 2 & Relatório de Fiscalização n ${ }^{\circ}$ 177/2014 \\
\hline 15 & Ramal do Entremontes/PE & 1 & Relatório de Fiscalização n 303/2014 \\
\hline \multicolumn{4}{|c|}{ Ministério da Saúde } \\
\hline 16 & Complexo Materno de Teresina/PI & $\begin{array}{l}4 \\
3\end{array}$ & $\begin{array}{l}\text { Relatório de Fiscalização n } 360 / 2013 \\
\text { Relatório de Fiscalização n }{ }^{\circ} \text { 237/2014 }\end{array}$ \\
\hline 17 & $\begin{array}{l}\text { UBS e UPAs - Unidades Básicas de } \\
\text { Saúde e Unidades de Pronto Atendimento }\end{array}$ & 4 & Relatório de Fiscalização n 260/2014 \\
\hline \multicolumn{4}{|c|}{ Secretaria de Portos } \\
\hline \multirow[t]{2}{*}{18} & Dragagem do Porto de Santos/SP & 1 & Relatório de Fiscalização n 132/2014 \\
\hline & TOTAL & 67 & \\
\hline
\end{tabular}

Fonte: Autor. 
Quanto aos acórdãos originados pelos 28 Relatórios, a Tabela 4.5 apresenta os acórdãos por relatório e por empreendimento.

Para fins de melhor visualização, a referência aos acórdãos do Tribunal de Contas da União está efetuada de forma simplificada, onde AC designa o acórdão e o $\mathrm{P}$ indica que trata-se de uma decisão do Plenário. 
Tabela 4.5 - Quantidade de acórdãos por relatório e por empreendimento

\begin{tabular}{|c|c|c|c|}
\hline $\mathbf{N}$ & Referência ao Empreendimento & $\begin{array}{l}\text { Relatório } \\
\text { vinculado }\end{array}$ & Acórdão vinculado por relatório \\
\hline \multicolumn{4}{|c|}{ DNIT } \\
\hline 1 & BR-101/PE - Anel Viário de Recife & $118 / 2014$ & Relatório ainda não apreciado pelo $T C U$ \\
\hline 2 & BR-156/AP - Pavimentação & $58 / 2014$ & AC 1749/2014-P \\
\hline 3 & BR-163/MT - Pavimentação & $1408 / 2012$ & AC 1465/2013-P \\
\hline 4 & BR-163/PA - Pavimentação & $\begin{array}{c}1399 / 2012 \\
24 / 2014\end{array}$ & $\begin{array}{l}\text { AC 1310/2013-P } \\
\text { Relatório ainda não apreciado pelo TCU }\end{array}$ \\
\hline 5 & BR-174/MT - Pavimentação & $715 / 2013$ & AC 2453/2014-P e AC 15/2015-P \\
\hline 6 & BR-316/AL - Pavimentação & $53 / 2014$ & Relatório ainda não apreciado pelo $T C U$ \\
\hline 7 & BR-381/MG - Duplicação & $\begin{array}{c}1361 / 2012 \\
1362 / 2012 \\
1363 / 2012 \\
1365 / 2012 \\
1366 / 2012 \\
123 / 2014\end{array}$ & $\begin{array}{l}\text { Relatório ainda não apreciado pelo TCU } \\
\text { Relatório ainda não apreciado pelo TCU } \\
\text { Relatório ainda não apreciado pelo TCU } \\
\text { Relatório ainda não apreciado pelo TCU } \\
\text { Relatório ainda não apreciado pelo TCU } \\
\text { AC } 1671 / 2014-\mathrm{P} \text { e AC 163/2015-P }\end{array}$ \\
\hline 8 & Programa BR-Legal - Sinalização Viária & $\begin{array}{l}298 / 2013 \\
299 / 2013\end{array}$ & $\begin{array}{l}\text { AC } 2163 / 2013-\mathrm{P} \text { e AC } 1888 / 2014-\mathrm{P} \\
\text { AC } 2164 / 2013-\mathrm{P} \text { e AC } 1399 / 2014-\mathrm{P} \\
\text { AC } 2011 / 2015-\mathrm{P}\end{array}$ \\
\hline 9 & $\begin{array}{l}\text { Construção da } 2^{\text {a }} \text { Ponte sobre o Rio } \\
\text { Guaíba/RS }\end{array}$ & $717 / 2013$ & AC 1167/2014-P \\
\hline 10 & $\begin{array}{l}\text { Derrocamento na Hidrovia do Rio } \\
\text { Tocantins/PA }\end{array}$ & $173 / 2014$ & Relatório ainda não apreciado pelo $T C U$ \\
\hline 11 & Porto de Manaus/AM & $\begin{array}{c}303 / 2013 \\
32 / 2014\end{array}$ & $\begin{array}{l}\mathrm{AC} 2745 / 2013-\mathrm{P} \\
\text { Relatório ainda não apreciado pelo } T C U\end{array}$ \\
\hline \multicolumn{4}{|c|}{ Infraero } \\
\hline 12 & TPS-3 do Aeroporto de Confins/MG & $254 / 2013$ & AC 1814/2013-P \\
\hline 13 & TPS do Aeroporto Afonso Pena/PR & $\begin{array}{c}1344 / 2012 \\
87 / 2014\end{array}$ & $\begin{array}{l}\text { AC 1510/2013-P } \\
\text { AC 1439/2014-P }\end{array}$ \\
\hline \multicolumn{4}{|c|}{ Ministério da Integração Nacional } \\
\hline 14 & Ramal do Agreste/PE & $177 / 2014$ & AC $2547 / 2014-\mathrm{P}$ e AC $1850 / 2015-\mathrm{P}$ \\
\hline 15 & Ramal do Entremontes/PE & $303 / 2014$ & AC 2690/2014-P \\
\hline \multicolumn{4}{|c|}{ Ministério da Saúde } \\
\hline 16 & Complexo Materno de Teresina/PI & $\begin{array}{l}360 / 2013 \\
237 / 2014\end{array}$ & $\begin{array}{l}\text { AC 2019/2013-P e AC 2354/2014-P } \\
\text { AC 2693/2014-P e AC 253/2015-P }\end{array}$ \\
\hline 17 & $\begin{array}{l}\text { UBS e UPAs - Unidades Básicas de } \\
\text { Saúde e Unidades de Pronto Atendimento }\end{array}$ & $260 / 2014$ & Relatório ainda não apreciado pelo $T C U$ \\
\hline \multicolumn{4}{|c|}{ Secretaria de Portos } \\
\hline 18 & Dragagem do Porto de Santos/SP & $132 / 2014$ & AC 1541/2014-P \\
\hline
\end{tabular}

Fonte: Autor. 
Ao todo foram proferidos até o momento da pesquisa 25 acórdãos, contudo, observa-se que a quantidade de acórdãos irá aumentar à medida que cada relatório de fiscalização que está aguardando apreciação pela Corte do Tribunal de Contas for julgado.

É oportuno registrar que além desses 28 relatórios, suas 67 constatações e os 25 acórdãos decorrentes dessas fiscalizações nos 18 empreendimentos auditados pelo TCU a base de análise para verificar se os pressupostos e parâmetros sobre riscos definidos na revisão bibliográfica estão sendo efetivamente observados nas contratações integradas que foram objeto de avaliação incluem também a fiscalização temática no Programa Proinfância/FNDE (Fiscobras 2013) e as quatro fiscalizações provenientes de representações em licitações do DNIT (Fiscobras 2014).

Destaca-se que 6 dos 25 acórdãos não puderam ser consultados em virtude de que os mesmos estão em sigilo, quando do momento da realização dessa pesquisa. Explicita-se a seguir a relação dos mesmos por empreendimento:

- BR-156/AP: Acórdão 1749/2014-TCU-Plenário, de 2/7/2014;

- $\quad$ Ramal do Agreste: Acórdão 2547/2014-TCU-Plenário, de 24/9/2014;

- Ramal Entremontes: Acórdão 2690/2014-TCU-Plenário, de 8/10/2014.

- Complexo Materno em Teresina/PI: Acórdão 2019/2013-TCU-Plenário, de 31/07/2013; Acórdão 2354/2014-TCU-Plenário, de 03/09/2014 e Acórdão 2693/2014-TCU-Plenário, de 08/10/2014.

Da relação de 19 acórdãos efetivamente disponibilizados para consulta verifica-se que 3 foram prolatados em decorrência de oitivas das partes interessadas e que outros 3 foram proferidos para avaliar o cumprimento de deliberações anteriores pelo órgão contratante, conforme relação a seguir discriminada por empreendimento:

- Programa BR-Legal: Acórdão 1399/2014-TCU-Plenário e Acórdão 1888/2014TCU-Plenário, ambos, decorrentes de oitivas de deliberações anteriores;

- $\quad$ TPS do Aeroporto Afonso Pena/PR: Acórdão 1439/2014-TCU-Plenário, proferido para avaliar o cumprimento de deliberação anterior;

- BR-174/MT: Acórdão 15/2015-TCU-Plenário, proferido para avaliar o cumprimento de deliberação anterior; 
- BR-381/MG: Acórdão 163/2015-TCU-Plenário, proferido para avaliar o cumprimento de deliberação anterior;

- Complexo Materno de Teresina/PI: Acórdão 253/2015-TCU-Plenário, decorrente de oitiva;

Em síntese, os seis supracitados acórdãos não trouxeram novas questões técnicas para análise e por esta razão deixaram de ser considerados na análise.

Adicionalmente um aspecto relevante sobressai desse universo de contratações auditadas, que é o fato de que houve a revogação de um dos lotes avaliados da BR-381/MG e outros 8 certames também não lograram êxito, conforme a seguir apresentado por ordem cronológica de publicação:

- BR-381/MG - Lote 8A: certame revogado por não ter proposta abaixo do preço de referência (Diário Oficial da União de 28/08/2013, seção 3, folha 154);

- TPS-3 do Aeroporto de Confins/MG: licitação deserta, conforme publicado no Diário Oficial da União de 15/07/2013, seção 3, folha 7;

- Dragagem do Porto de Santos/SP: certame fracassado, uma vez que os preços finais ofertados pelos licitantes encontravam-se acima do valor estimado pela Administração, conforme Ata da Comissão de Licitação de 08/04/2014;

- BR-316/AL: certame anulado, conforme Aviso de Anulação publicado no Diário Oficial da União de 11/06/2014, seção 3, folha 152;

- Derrocamento na Hidrovia do Rio Tocantins/PA: certame anulado, conforme Aviso publicado no Diário Oficial da União de 17/6/2014, seção 3, folha 172;

- $\quad$ BR-101/PE - Anel Viário de Recife: certame revogado em virtude da necessidade de ajustes no Anteprojeto de Engenharia para atendimento de condicionantes ambientais (Diário Oficial da União de 23/07/2014, seção 3, folha 196);

- Ramal do Agreste/PE: certame revogado, conforme Aviso de Revogação publicado no Diário Oficial da União de 3/11/2014, seção 3, folha119;

- Complexo Materno de Teresina/PI: certame anulado, conforme Diário Oficial do Estado do Piauí em 27/11/2014, folha 35; 
- $\quad$ UBS e UPAs - Unidades Básicas de Saúde e Unidades de Pronto Atendimento: todas as licitantes foram desclassificadas em função de propostas com preços superiores aos valores orçados pelo Ministério, conforme publicado no Diário Oficial da União de 17/6/2014, seção3, folha 126.

A descontinuidade dessas contratações em nada afeta as análises do presente trabalho, contudo, uma consequência direta desses certames fiscalizados pelo TCU é que os mesmos não representam empreendimentos efetivamente contratados, sendo esta a razão para o fato de não terem sido considerados no levantamento de certames.

\subsection{PRIMEIRO FÓRUM DE DEBATE SOBRE RISCOS EM OBRAS PÚBLICAS DA UNIVERSIDADE DE BRASÍLIA}

As informações reunidas na fase de levantamento foram determinantes para a definição da estrutura de temas e palestras a compor o $1^{\circ}$ Fórum da Universidade de Brasília de debate sobre Riscos em Obras Públicas.

As discussões ocorridas no âmbito do Fórum centraram-se na metodologia de gerenciamento de riscos para obras rodoviárias instituída de forma pioneira pelo Departamento Nacional de Infraestrutura de Transportes - DNIT, pois a mesma se constitui na principal referência nacional sobre gerenciamento de riscos aplicada a obras na modalidade contratação integrada no âmbito do RDC.

Além do Guia PMBOK (2013), as referências das publicações elaboradas pelo DNIT, Instrução de Serviço/DG n ${ }^{\circ}$ 01, de 2/1/2014 e Guia de Gerenciamento de Riscos de Obras Rodoviárias - Fundamentos, foram o Guia FHWA (2006,b) e o Caltrans (2012).

A apresentação propriamente dita foi baseada na abordagem de cada etapa que compõe a sequência da metodologia: i) identificação de riscos, ii) análise quantitativa de riscos e iii) planejamento das respostas aos riscos.

Destaca-se que a elaboração dessa metodologia visou dar efetivo cumprimento aos comandos estabelecidos no Decreto regulamentar do RDC, os quais preveem a possibilidade de inserção da taxa de risco (reserva de contingência) nos orçamentos estimados das contratações integradas desde que fundamentada em metodologia formalmente aprovada. 
De acordo com a metodologia desenvolvida, a reserva de contingência é um valor estabelecido a partir de cenários de riscos que é acrescido ao orçamento estimado de referência, com vistas a remunerar a transferência de riscos ao contratado.

A primeira etapa da metodologia objetiva a identificação dos riscos que podem impactar o empreendimento e é encerrada com a conclusão da matriz de riscos, que é o instrumento que registra os riscos identificados, os agrupa por família de serviços e os aloca entre as partes que serão responsáveis pelo ônus financeiro em termos contratuais (contratante, contratada, seguradora).

A etapa de análise quantitativa de riscos se caracteriza pela análise numérica da probabilidade de ocorrência de cada risco listado na matriz de riscos e avaliação do impacto dos riscos no valor do empreendimento, por meio da técnica matemática de simulação de Monte Carlo, efetuado a partir do aplicativo @Risk instalado no Microsoft Excel.

$\mathrm{Na}$ etapa de planejamento das respostas aos riscos, há objetivamente a precificação do risco transferido, onde os gestores analisam os vários cenários possíveis de orçamentos e definem aquele que melhor reflete a realidade de um determinado empreendimento.

Definido o cenário, a reserva de contingência é quantificada e é alocada no orçamento estimado do empreendimento, com vistas a remunerar a transferência dos riscos ao contratado.

Em contraposição a proposta do DNIT, destaca-se a metodologia de Baeta $(2014, b)$ com abordagem conceitual alternativa para o cálculo de contingências a partir de simulações de Monte Carlo.

Com o intuito de dar amplo conhecimento aos temas tratados no âmbito do Fórum, todas as apresentações realizadas foram disponibilizadas no sítio eletrônico do evento, http://riscosemobraspublicas.blogspot.com.br/.

Ademais, todas as discussões e debates formulados durante Fórum se constituíram em importante insumo para avaliação da compreensão do tema gestão de riscos e foram sistematizados em um artigo, Caldeira (2015). 


\subsection{MATRIZES DE AVALIAÇÃO DO NÍVEL DE MATURIDADE}

As matrizes de avaliação do nível de maturidade buscam representar quão próximo está o órgão da aplicação dos conceitos de gerenciamento de riscos tendo como referência os marcos legais instituídos nessa nova dinâmica de contratação.

Matriz de avaliação do nível de maturidade em relação às fases de identificação e análise quantitativa de riscos

A figura 4.1, a seguir, representa o posicionamento gráfico das principais instituições contratantes em cada um dos cenários apresentados, incluindo o subgrupo de órgãos que não realizaram certames nesse regime de execução contratual, que foram alocados a título de posicionamento no Cenário I.

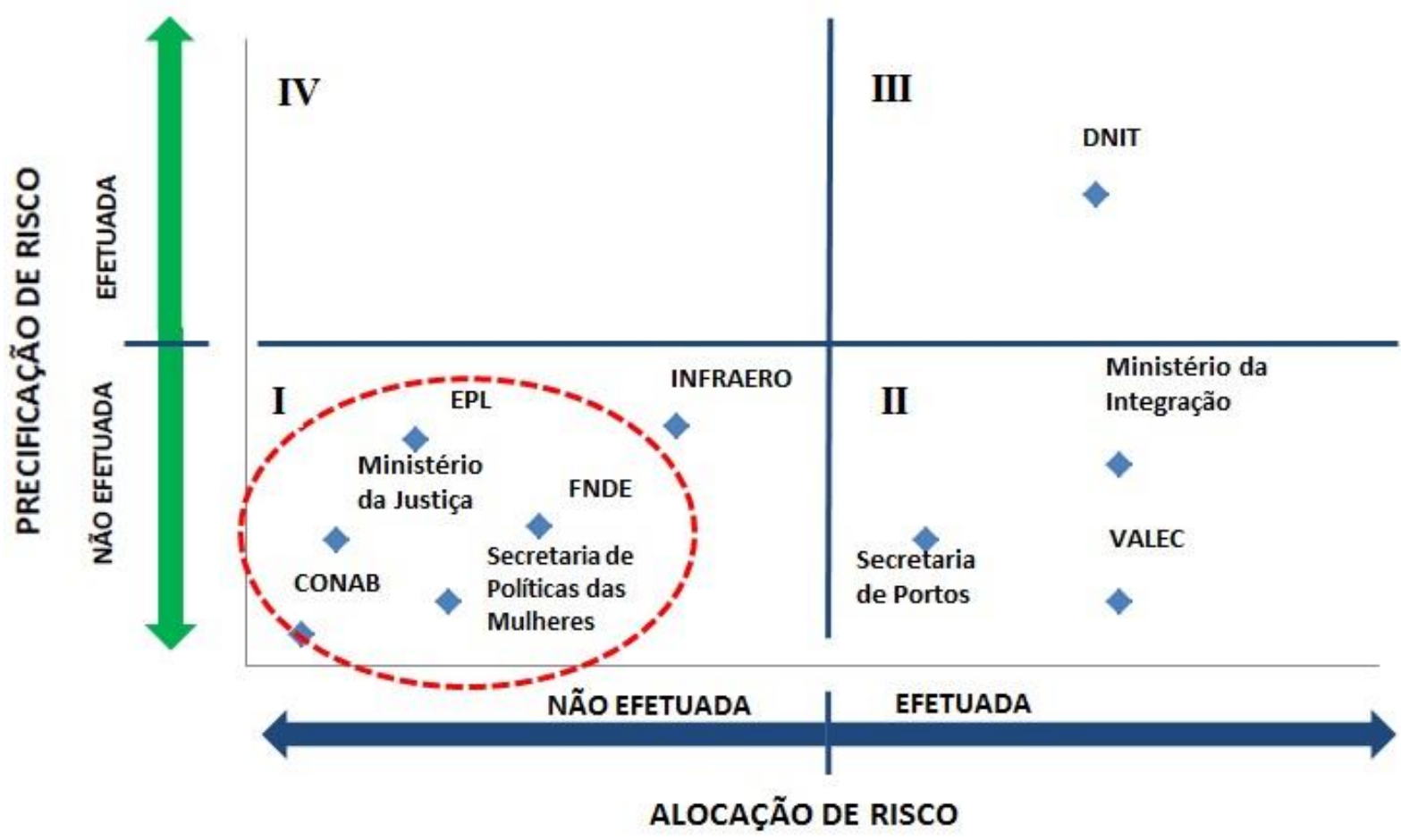

Figura 4.1 - Cenários de Maturidade em relação as fases de identificação e análise quantitativa de riscos

Fonte: Autor. 
Em síntese, a maioria dos órgãos encontra-se nos estágios I (maturidade inicial) e II (maturidade intermediária). O DNIT, além de pioneiro no estabelecimento de uma metodologia de gerenciamento de riscos, comparativamente aos demais, é o órgão que se encontra no estágio III (maturidade adequada), pois, em que pese a necessidade de aperfeiçoamento da metodologia, é o único órgão da administração pública federal que alocou e precificou o risco dos empreendimentos licitados na modalidade contratação integrada.

Conforme anteriormente relatado, importa destacar que o Cenário IV (inadequado), onde o risco não é alocado, contudo é precificado, é um cenário hipotético, pois não é possível precificar o risco sem alocá-lo antes.

Outra questão importante a ser avaliada se refere a alteração legislativa (primeiramente ocorrida no âmbito da Medida Provisória n 630, de 24/12/2013, posteriormente convertida na Lei $n^{\circ} 12.980$, de 28/5/2014) que desobrigou a adoção do critério de julgamento de técnica e preço.

Após a referida alteração, ocorreram a publicação de 14 certames que foram homologados até 2014, conforme Tabela 4.6. 


\begin{tabular}{|c|c|}
\hline Edital & Objeto \\
\hline \multicolumn{2}{|l|}{ DNIT } \\
\hline 0046/14-00 & $\begin{array}{l}\text { Contratação integrada de empresa para desenvolvimento dos Projetos Básico e Executivo e execução das obras e } \\
\text { demais operações necessárias e suficientes para a construção da Ponte Internacional sobre o rio Paraná ligando o } \\
\text { Brasil (Foz do Iguaçu) e o Paraguai (Presidente Franco). }\end{array}$ \\
\hline 0102/14-00 & $\begin{array}{l}\text { Contratação Integrada de empresas para Elaboração dos Projetos Básico e Executivo e Execução das Obras de } \\
\text { Adequação de Capacidade da Rodovia BR-381/MG (Norte), incluindo Duplicação, Melhoramentos e Ampliação de } \\
\text { Capacidade e Segurança de segmentos do trecho Divisa ES/MG - Divisa MG/SP, } 03 \text { (três) lotes. }\end{array}$ \\
\hline 0130/14-00 & $\begin{array}{l}\text { Contratação de Empresa para a Elaboração de Projeto Básico e Executivo de Engenharia e Execução dos Serviços } \\
\text { Técnicos de Aplicação e Manutenção de Dispositivos de Segurança e de Sinalização Rodoviária, no âmbito do } \\
\text { Programa Nacional de Segurança e Sinalização Rodoviária - BR-Legal, nas rodovias BR- } 116 / 135 / 242 / 324 \text { do estado } \\
\text { da Bahia, BR-010/153/222/230/308/316/422 do estado do Pará, subdividida em } 6 \text { lotes, totalizando } 2.470,10 \mathrm{~km} \text {. }\end{array}$ \\
\hline 0131/14-00 & $\begin{array}{l}\text { Contratação de Empresa para a Elaboração de Projeto Básico e Executivo de Engenharia e Execução dos Serviços } \\
\text { Técnicos de Aplicação e Manutenção de Dispositivos de Segurança e de Sinalização Rodoviária, no Âmbito Do } \\
\text { Programa Nacional De Segurança e Sinalização Rodoviária - BR-Legal, Nas Rodovias BR- 030/101/122/135/349/415 } \\
\text { Do Estado Da Bahia, Br-174/230/317/319 Do Estado Da Amazonas, Br-174/210/401/432 Do Estado De Roraima, } \\
\text { Subdividida Em } 7 \text { (Sete) Lotes, Totalizando 2.919,90 Km. }\end{array}$ \\
\hline 0139/14-00 & $\begin{array}{l}\text { Contratação Integrada de empresa para a prestação de serviços técnicos especializados de engenharia para a } \\
\text { Elaboração dos Projetos Básico e Executivo e Execução das Obras de Restauração na Rodovia BR 155/PA. }\end{array}$ \\
\hline 0272/14-00 & $\begin{array}{l}\text { Contratação de serviços técnicos especializados de engenharia para a Elaboração do Projeto Básico e Executivo e } \\
\text { Execução das Obras de Implantação e Pavimentação de Ruas Laterais com Transposição da Rodovia por Obras de } \\
\text { Artes Especiais, com Melhoramentos para Adequação de Capacidade e Segurança na Rodovia BR 364/RO. }\end{array}$ \\
\hline 0363/14-00 & $\begin{array}{l}\text { Contratação Integrada de Empresa para a Prestação de Serviços Técnicos Especializados de Engenharia para } \\
\text { Elaboração do Projeto Básico e Executivo e Execução das Obras Remanescentes de Implantação do Plano Rodoviário } \\
\text { de Juiz de Fora (Adequação da Capacidade de Tráfego), incluindo OAE's, na rodovia BR-440/MG. }\end{array}$ \\
\hline 0365/14-00 & $\begin{array}{l}\text { Contratação Integrada de empresa para Elaboração do Projeto Básico e Executivo de Engenharia e Execução das } \\
\text { Obras para Duplicação de Rodovia e Restauração da Pista Existente e Obras-de-Arte Especiais na BR-262/ES }\end{array}$ \\
\hline 0599/14-00 & $\begin{array}{l}\text { Contratação Integrada de empresa para Elaboração dos Projetos Básico e Executivo e Execução das Obras de } \\
\text { Implantação e Pavimentação, incluindo Obras de Arte Especiais, na rodovia BR-447/ES }\end{array}$ \\
\hline 0693/14-00 & $\begin{array}{l}\text { Contratação de Empresa ou Consórcio de Empresas para a Elaboração dos Projetos de Engenharia, Construção, } \\
\text { Manutenção, Conservação e Execução dos Serviços de Coleta de Dados de Veículos Pesados através de } \\
\text { PostosIntegrados Automatizados de Fiscalização - PIAF, no âmbito do Plano Nacional de Pesagem, nas rodovias: BR- } \\
\text { 101/RN, BR-226/RN, BR-304/RN, BR-135/MA, BR-316/MA, BR-020/PI, BR-135/PI, BR-230/PI e BR-316/PI, } \\
\text { subdividida em 06 (seis) lotes, totalizando 11(onze) PIAF. }\end{array}$ \\
\hline 0695/14-00 & $\begin{array}{l}\text { Contratação Integrada de Empresa ou Consórcio de Empresas para a Elaboração dos Projetos de Engenharia, } \\
\text { Construção, Manutenção, Conservação e Execução dos Serviços de Coleta de Dados de Veículos Pesados através de } \\
\text { Postos Integrados Automatizados de Fiscalização - PIAF, no âmbito do Plano Nacional de Pesagem, nas rodovias: } \\
\text { BR-010/PA, BR-230/PA, BR-163/PA, BR-163/MT, BR-158/MS e BR-364/RO, subdividida em 05 (cinco) lotes, } \\
\text { totalizando 07 (sete) PIAF. }\end{array}$ \\
\hline 0696/14-00 & $\begin{array}{l}\text { Contratação Integrada de Empresa ou Consórcio de Empresas para a Elaboração dos Projetos de Engenharia, } \\
\text { Construção, Manutenção, Conservação e Execução dos Serviços de Coleta de Dados de Veículos Pesados através de } \\
\text { Postos Integrados Automatizados de Fiscalização - PIAF, no âmbito do Plano Nacional de Pesagem, nas rodovias: } \\
\text { BR-476/PR, BR-163/PR, BR-158/RS, BR-472/RS e BR-280/SC, subdividida em } 04 \text { (quatro) lotes, totalizando } 06 \\
\text { (seis) PIAF. }\end{array}$ \\
\hline \multicolumn{2}{|l|}{ VALEC } \\
\hline $006 / 2014$ & $\begin{array}{l}\text { Contratação de empresa para elaboração dos projetos básico e executivo e execução das obras e serviços } \\
\text { remanescentes, localizados no município de Rio Verde/GO, posicionado no km } 357+800 \text { ao km 364+172 } \\
\text { e a implantação da grade (lastro, dormentes e trilhos) entre os km } 315+800 \text { e } 394+900 \text { da Extensão Sul, } \\
\text { da Ferrovia Norte-Sul. }\end{array}$ \\
\hline
\end{tabular}

\section{Secretaria de Portos}

RDC Contratação de empresa ou consórcio de empresas para a Elaboração dos Projetos Básico e Executivo e a

Presencial Execução da Obra de Dragagem por resultado para ampliação do Acesso da Infraestrutura Aquaviária ao

SEP/PR N ${ }^{\circ}$ Complexo Portuário do Rio de Janeiro/RJ, bem como o fornecimento e instalação de novos Cabos

04/2014 Submarinos de energia elétrica, incluindo instalação do Sistema de Geração de Energia em Emergência,

04/2014 fornecimento e instalação de novos Alimentadores de Energia Elétrica e nova Adutora de Água Potável.

Quadro 4.2 - Quantitativo de licitações na modalidade contratação integrada publicadas após a Medida Provisória n ${ }^{\circ}$ 630, de 24/12/2013 e homologadas até 2014

Fonte: Autor. 
Desse total, apenas 3 licitações não foram realizadas no critério de julgamento menor preço, conforme a seguir detalhado:

- Edital 0046/14-00, critério técnica e preço, pois a publicação do extrato desse certame ocorreu em 31/1/2014, indicando que o planejamento e desenho da contratação foi delineado antes da alteração efetuada; e

- Editais 0130/14-00 e 0131/14-00, pois seguiram a mesma referência do critério de técnica e preço de outros 5 certames realizados no âmbito do mesmo Programa BRLegal.

Como observado, com a alteração na legislação os órgãos nacionais passaram a optar pelo critério de menor preço, desfigurando o modelo brasileiro em relação às referências internacionais.

Tal alteração tem caráter dissonante com a prática americana de contratações, visto que a seleção unicamente pelo critério de menor preço incentiva a ocorrência da maldição do vencedor, relatada em Fiuza (2014).

$\underline{\text { Matriz de avaliação do nível de maturidade em relação à fase de planejamento de respostas }}$ $\underline{\operatorname{aos} \operatorname{riscos}}$

A figura 4.2, a seguir, representa o posicionamento gráfico das principais instituições contratantes em cada um dos cenários apresentados, incluindo o subgrupo de órgãos que não realizaram certames nesse regime de execução contratual, que foram alocados a título de posicionamento no Cenário I. 


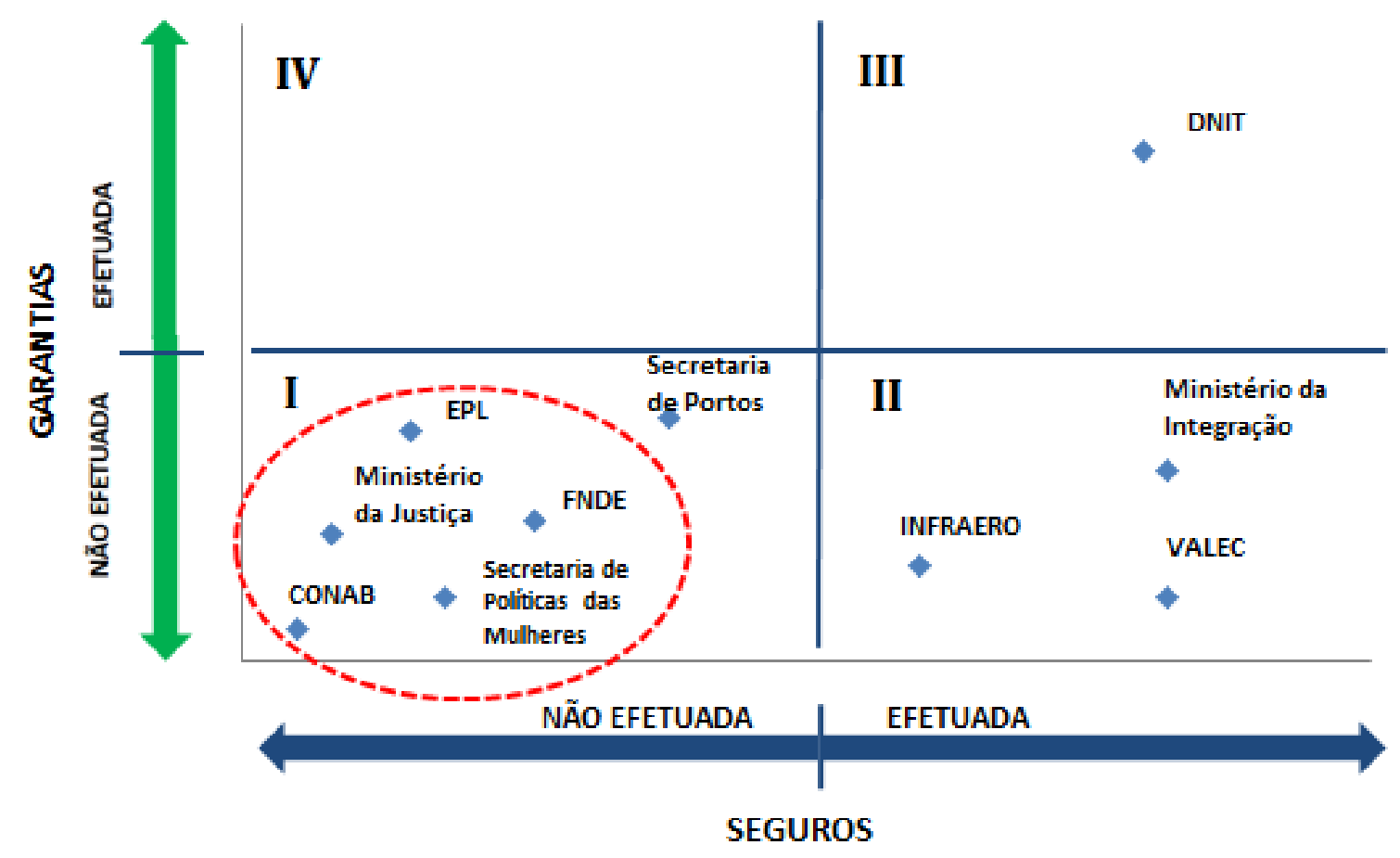

Figura 4.2 - Cenários de Maturidade em relação à fase de planejamento de respostas aos riscos

Fonte: Autor.

O DNIT é o único órgão alocado no estágio de maturidade adequada nessa dimensão de avaliação. Em contraposição, a Secretaria de Portos aparece no estágio de maturidade inicial por não ter adotado nem condições de seguros e nem condições de garantias compatíveis com as condições de mercado. Infraero, Ministério da Integração Nacional e VALEC adotam apenas condições de seguros compatíveis com as de mercado, por isso se encontram no estágio de maturidade intermediária.

Em síntese, em caso da ocorrência de sinistros nas contratações objeto deste estudo que foram licitadas pela Infraero, Ministério da Integração, Secretaria de Portos e VALEC, os valores a serem ressarcidos estão limitados aos percentuais estabelecidos na lei $\mathrm{n}^{\circ}$ 8.666/93.

Conforme levantado, apenas duas metodologias, DNIT e Ministério da Integração Nacional, foram instituídas pelos órgãos do Poder Executivo Federal para precificação de riscos.

Em linhas gerais tem-se que os resultados da avaliação de maturidade do DNIT tendo como referência o marco legal não se mantiveram quando da avaliação específica de sua 
metodologia. Mais insipiente ainda foram os resultados da avaliação da metodologia do Ministério da Integração Nacional.

\section{Metodologia de Riscos instituída pelo DNIT}

A análise teve como referência a Instrução de Serviço/DG n ${ }^{\circ}$ 01, de 2/1/2014, Guia de Gerenciamento de Riscos de Obras Rodoviárias - Fundamentos, ambos do DNIT, complementada com aspectos extraídos do Relatório n 1361/2012 (ainda não apreciado pelo TCU).

As principais observações em relação ao método são a seguir discutidas.

1. Planejamento do gerenciamento dos riscos - A metodologia não instituiu um plano de gerenciamento dos riscos.

2. Identificação dos riscos $-O$ processo de categorização dos riscos que possibilitou a montagem da matriz de riscos foi organizado a partir do agrupamento dos riscos por famílias de serviços (Terraplenagem, Drenagem e Obras-de-Arte Correntes, Pavimentação, Sinalização, Obras Complementares, Meio Ambiente e Paisagismo e Obras-de-Arte Especiais), de modo que não foram levados em consideração riscos específicos do projeto e possíveis riscos secundários.

3. Realização da análise qualitativa dos riscos - Os riscos não foram identificados de acordo com a magnitude do efeito no custo, conforme o nível de maturidade do orçamento previsto na RP 41R-08 (2008). A análise qualitativa não foi considerada na metodologia do DNIT.

4. Realização da análise quantitativa dos riscos - A metodologia instituída não apresenta fundamentação para os níveis de apetite ao risco e função densidade de probabilidade adotados.

A instrução de serviço estipula em 50\% o nível de confiabilidade para as análises de riscos realizadas a partir de dados históricos e em $80 \%$ o nível de confiabilidade para as análises baseadas em dados da literatura ou ainda em opinião de especialistas, desde que não seja possível a obtenção de dados históricos. Em ambas as análises é explicitado que diferentes valores de nível de confiabilidade podem ser empregados em 
caso de motivação devidamente justificada, contudo, nenhum paramêtro orientativo para guiar a elaboração da fundamentação é apresentado.

Em que pese o estabelecimento de dois possíveis níveis de confiabilidade, em termos práticos a aplicação, em regra, será efetuada no nível de confiabilidade de $80 \%$ definido para as licitações efetuadas com Anteprojeto de Engenharia.

Considerando que os recursos geridos pela autarquia são públicos e sua utilização deve ser pautada segundo os princípios da eficiência e economicidade, avalia-se, tendo como referência a prática recomendada RP 41R-08, que o nível de apetite ao risco estabelecido para licitações com Anteprojeto de Engenharia acarreta um excesso de contingência.

Em relação a função densidade de probabilidade, a metodologia utiliza a distribuição PERT tendo como referência apenas a citação da literatura, sem realizar nenhuma avaliação sobre a adequabilidade de outras funções.

Registra-se que segundo a RP 41R-08 (2008) as funções densidades de probabilidade que mais razoavelmente refletem o comportamento dos fatores de risco em uma simulação de Monte Carlo são a distribuição triangular e a distribuição duplo triangular.

Destaca-se também que a metodologia utilizada dados históricos relativos ao impacto financeiro das Revisões de Projeto em Fase de Obras, medidos diretamente da amostra, por meio da frequência de ocorrência de aditivos e dos percentuais de aditivos, após a adoção do método de Box-Whisker para eliminação dos pontos destoantes da base de dados.

Contudo, Filho (2014), Coordenador-Geral de Custos de Infraestrutura de Transportes do DNIT, no âmbito de palestra realizada em 23 de setembro de 2014 intitulada "Elaboração de Orçamentos sob a Égide da Lei 8666/93 e do Regime Diferenciado de Contratação" durante o $1^{\circ}$ Seminário de Licitações e Contratos do DNIT, registrou inúmeras não-conformidades em relação ao modelo de orçamentação em que o risco encontrasse inserido. Em síntese, os apontamentos caracterizam inconsistências, não padronizações, lacunas, falhas e distorções na base de dados que suporta o sistema de acompanhamento de contratos da instituição. 
5. Planejamento das respostas aos riscos - A metodologia somente prevê duas estratégias perante o risco (aceitar ou transferir) que, de acordo com o Guia PMBOK (2013) podem representar um desafio para a implantação de um efetivo plano de gerenciamento de riscos.

6. Controle dos riscos - A metodologia não prevê processos específicos de avaliação da eficiência do processo de riscos, como parte integrante do plano de gerenciamento de riscos.

Pelo exposto, verifica-se que a metodologia de riscos instituída pelo DNIT necessita de significativos aperfeiçoamentos, visto que importantes aspectos do processo de gerenciamento de riscos foram abordados de forma superficial, isto é, sem a devida fundamentação, ou simplesmente não foram abordados.

\section{$\underline{\text { Metodologia de Riscos instituída pelo Ministério da Integração Nacional }}$}

A metodologia para identificação, quantificação e alocação de riscos do Ministério da Integração Nacional foi aprovada especificamente para as licitações concernentes ao Projeto de Integração do Rio São Francisco com Bacias Hidrográficas do Nordeste Setentrional - PISF, nos termos da Portaria n 118, de 18 de março de 2014.

Das limitações dessa metodologia destaca-se a sua aplicabilidade limitada apenas a obras vinculadas ao Projeto de Integração do Rio São Francisco com Bacias Hidrográficas do Nordeste Setentrional - PISF e a utilização apenas duas únicas fontes de referência para sua elaboração, sendo uma delas o Guia PMBOK (2013) e a outra o Guia de Gerenciamento de Riscos do DNIT.

O referencial normativo do Ministério da Integração resume-se a descrição, em linhas gerais, de conceitos gerais referentes ao processo de gerenciamento de riscos, sem apresentar referências sobre os critérios, premissas e demais condições de contorno que devem ser considerados para a utilização da metodologia.

As principais observações em relação ao método do Ministério da Integração Nacional são a seguir discutidas. 
1. Planejamento do gerenciamento dos riscos - A metodologia não instituiu um plano de gerenciamento dos riscos.

2. Identificação dos riscos - A metodologia cita sem qualquer tipo de detalhamento seis categorias de riscos que são primordialmente utilizadas.

3. Realização da análise qualitativa dos riscos $-A$ análise qualitativa é apenas citada como parte integrante da fase de identificação de riscos.

4. Realização da análise quantitativa dos riscos - A metodologia instituída não faz menção ao nível de apetite ao risco e não traz fundamentação para a utilização da função distribuição normal padrão.

5. Planejamento das respostas aos riscos - A metodologia não faz menção às estratégias perante o risco que foram consideradas.

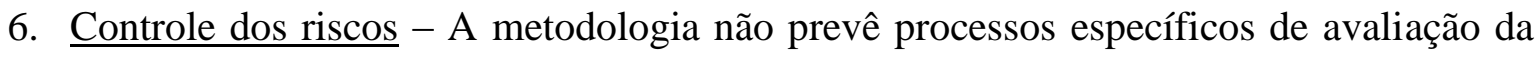
eficiência do processo de riscos, como parte integrante do plano de gerenciamento de riscos.

Em síntese, ambas as metodologia de riscos instituídas caracterizam-se pela incompletude da implantação do processo de gerenciamento de riscos de acordo com o Guia PMBOK (2013), o que exige dos gestores que estão à frente desses órgãos, uma tempestiva ação com vistas a melhoria técnica de seus processos de contratação.

Registra-se também que ambas as metodologias não abordam os riscos e as contingências de cronograma, com isso o modelo não prevê repercussões financeiras que aditivos de prazos podem acarretar no caso de atrasos em relação ao prazo final de conclusão do empreendimento.

Em termos objetivos, tem-se que o baixo grau de maturidade verificado tem reflexo direto no conjunto de diretrizes formulado, visto que orientações complexas ou sofisticadas não se mostram aderentes à realidade dos órgãos. 


\subsection{ANÁLISE CRÍTICA DAS FISCALIZAÇÕES DO TRIBUNAL DE CONTAS DA UNIÃO}

As avaliações da prática observada nos empreendimentos licitados pelos órgãos e entidades do Poder Executivo Federal que optaram por adotar o RDC, em sua modalidade de contratação integrada, são efetuadas sobre uma perspectiva gerencial tendo como referência o estágio de maturidade e as fiscalizações e deliberações do Tribunal de Contas da União em relação aos principais aspectos levantados na revisão bibliográfica.

Conforme definido na metodologia, antes de adentrar na análise das constatações, primeiramente tem-se que apresentar os resultados da avaliação das questões de auditoria que foram formuladas em cada relatório, visto que as constatações são, em última análise, as "respostas" dessas questões.

Para fins de sistematização e melhor entendimento, as questões de auditoria foram agrupadas por empreendimento e não por relatório, conforme verificado na Tabela 4.6.

Por esta razão, uma mesma questão de auditoria pode ser observada mais de uma vez para um mesmo empreendimento.

Ao todo 13 questões de auditoria foram formuladas 114 vezes para avaliar os 18 empreendimentos. 
Tabela 4.6 - Relação da quantidade de questões de auditoria por empreendimento

\begin{tabular}{|c|c|c|c|c|c|c|c|c|c|c|c|c|c|c|c|c|c|c|c|c|}
\hline \multirow{3}{*}{$\mathbf{N}$} & \multirow{3}{*}{ Questão de Auditoria } & \multicolumn{18}{|c|}{ Empreendimento* } & \multirow{3}{*}{ TOTAL } \\
\hline & & 1 & 2 & 3 & 4 & 5 & 6 & 7 & 8 & 9 & 10 & 11 & 12 & 13 & 14 & 15 & 16 & 17 & 18 & \\
\hline & & \multicolumn{18}{|c|}{ Quantidade de questões de auditoria } & \\
\hline I & $\begin{array}{l}\text { Os preços dos serviços definidos no orçamento da obra são compatíveis com os } \\
\text { valores de mercado? }\end{array}$ & 1 & 1 & 1 & 1 & 1 & & 5 & 2 & 1 & 1 & 1 & 1 & 1 & 1 & 1 & 2 & 1 & 1 & 23 \\
\hline II & O procedimento licitatório foi regular? & 1 & & 1 & 1 & 1 & 1 & 1 & 2 & 1 & 1 & 1 & 1 & 1 & 1 & 1 & 2 & 1 & 1 & 19 \\
\hline III & Há projeto básico/executivo adequado para a licitação/execução da obra? & 1 & 1 & 1 & 1 & & & & 2 & & & 2 & & 2 & 1 & 1 & 2 & 1 & & 15 \\
\hline IV & $\begin{array}{l}\text { O orçamento da obra encontra-se devidamente detalhado (planilha de } \\
\text { quantitativos e preços unitários) e acompanhado das composições de todos os } \\
\text { custos unitários de seus serviços? }\end{array}$ & 1 & 1 & 1 & 1 & & & & 2 & & 1 & & & 1 & 1 & & 2 & & 1 & 12 \\
\hline $\mathrm{V}$ & $\begin{array}{l}\text { Os quantitativos definidos no orçamento da obra são condizentes com os } \\
\text { quantitativos apresentados no projeto básico / executivo? }\end{array}$ & 1 & & 1 & 1 & & & & 2 & & & & 1 & & 1 & 1 & 2 & 1 & & 11 \\
\hline VI & A previsão orçamentária para a execução da obra é adequada? & & 1 & 1 & 2 & & & & & & 1 & 2 & 1 & 1 & & & 1 & & 1 & 11 \\
\hline VII & $\begin{array}{l}\text { O tipo do empreendimento exige licença ambiental e foram realizadas todas as } \\
\text { etapas para esse licenciamento? }\end{array}$ & & 1 & & 1 & & & & & & & 2 & 1 & 2 & & 1 & & & 1 & 9 \\
\hline VIII & $\begin{array}{l}\text { Existem estudos que comprovem a viabilidade técnica e econômico-financeira do } \\
\text { empreendimento? }\end{array}$ & & & & & & & & & & & 1 & 1 & 1 & & 1 & & & & 4 \\
\hline IX & $\begin{array}{l}\text { A formalização e a execução do convênio (ou outros instrumentos congêneres) } \\
\text { foram adequadas? }\end{array}$ & & 1 & & & 1 & & & & & & & & & & & 1 & & & 3 \\
\hline $\mathrm{x}$ & $\begin{array}{l}\text { A formalização do contrato atendeu aos preceitos legais e sua execução foi } \\
\text { adequada? }\end{array}$ & & & & & & & & & & & 1 & & 1 & & & & & & 2 \\
\hline $\mathrm{XI}$ & $\begin{array}{l}\text { Existem estudos hidrológicos que comprovem adequadamente a viabilidade } \\
\text { hídrica do empreendimento? }\end{array}$ & & & & & & & & & & & & & & 1 & 1 & & & & 2 \\
\hline $\mathrm{XII}$ & $\begin{array}{l}\text { Caso a obra seja dependente do Pisf para ter funcionalidade, os cronogramas de } \\
\text { ambas as obras estão compatíveis? }\end{array}$ & & & & & & & & & & & & & & 1 & 1 & & & & 2 \\
\hline \multirow[t]{2}{*}{ XIII } & Questão para cadastramento de achados não típicos. & & & & & & & 1 & & & & & & & & & & & & 1 \\
\hline & TOTAL & 5 & 6 & 6 & 8 & 3 & 1 & 7 & 10 & 2 & 4 & 10 & 6 & 10 & 7 & 8 & 12 & 4 & 5 & 114 \\
\hline
\end{tabular}

* Os empreendimentos foram apresentados na mesma referência das tabelas 1.3, 1.4 e 1.5.

Fonte: Autor. 
Merecem destaque as seguintes observações sobre as constatações da Tabela 4.6:

a) A avaliação de compatibilidade de preços definidos pela administração com os valores de mercado (questão I) juntamente com a regularidade do processo licitatório (questão II) são os principais aspectos avaliados pelas auditorias realizadas, dado que ambas as avaliações foram realizadas em 17 dos 18 empreendimentos fiscalizados;

b) Enquanto que a avaliação de compatibilidade de preços (questão I) envolve aspecto de orçamentação de um projeto sendo uma apuração de caráter eminentemente técnico afeto ao campo da ciência da engenharia de custos visto que requer a aplicação dos métodos de cálculo de sobrepreço/superfaturamento, a avaliação da regularidade do processo licitatório (questão II) está concernente ao exame da legalidade e legitimidade dos atos de gestão em relação ao atendimento dos normativos que disciplinam o processo de licitação;

c) A avaliação da adequabilidade do projeto básico/executivo para a licitação e execução da obra (questão III) é a terceira questão mais recorrente, sendo efetuada em 11 dos 17 empreendimentos fiscalizados.

Preliminarmente importa o seguinte registro. Uma vez que as licitações efetuadas no regime da contratação integradas são efetuadas com Anteprojeto de Engenharia, verifica-se que cabe o seguinte ajuste na redação da questão de auditoria: "Há anteprojeto de engenharia adequado para a licitação e projeto básico/executivo adequado para a execução da obra?”;

Esta avaliação compreende aspectos afetos à área de engenharia realizados em dois momentos do processo de contratação, sendo o primeiro na fase interna da licitação relacionado com a concepção do anteprojeto e o segundo na fase de execução contratual, especificamente na atividade de fiscalização.

Contudo, para fins de diferenciação com as questões que analisam a fase da licitação sob aspectos legais, enquadra-se a primeira parte dessa questão na etapa de anteprojeto, dado que todas as análises empreendidas são de carácter vinculados à técnica da engenharia. A segunda parte da questão está vinculada à etapa de fiscalização. 
d) As questões de auditoria V, VIII, XI e XII também se vinculam a aspectos da técnica da engenharia, conforme a seguir demonstrado:

d.1) A questão V (Os quantitativos definidos no orçamento da obra são condizentes com os quantitativos apresentados no projeto básico/executivo?) requer avaliação crítica sobre a elaboração de orçamentos;

Verifica-se também nessa questão a necessidade de ajuste de redação: "Os quantitativos definidos no orçamento da obra são condizentes com os quantitativos apresentados no anteprojeto de engenharia?"

d.2) A questão VIII (Existem estudos que comprovem a viabilidade técnica e econômico-financeira do empreendimento?) está vinculada fundamentalmente a avaliação da adequabilidade e suficiência dos parâmetros que fundamentaram os estudos de viabilidade técnica e modelagem econômico-financeira;

d.3) As questões XI (Existem estudos hidrológicos que comprovem adequadamente a viabilidade hídrica do empreendimento?) e XII (Caso a obra seja dependente do Pisf para ter funcionalidade, os cronogramas de ambas as obras estão compatíveis?) são específicas para as obras de construção dos ramais do Agreste (Empreendimento $\mathrm{n}^{\circ}$ 14) e do Entremontes (Empreendimento $\mathrm{n}^{\circ} 15$ ) e ambas requerem avaliações técnicas sobre os estudos hidrológicos e sobre cronograma;

e) As questões de auditoria IV, VI e VII dizem respeito à etapa da licitação propriamente dita:

e.1) A questão IV [O orçamento da obra encontra-se devidamente detalhado (planilha de quantitativos e preços unitários) e acompanhado das composições de todos os custos unitários de seus serviços?] visa avaliar o cumprimento de formalidades exigidas.

Registra-se que trata-se de questão controversa sob o prisma da boa técnica de orçamentação, haja vista que o orçamento que acompanha o Anteprojeto de Engenharia é estimativo e pode se valer de estimativas paramétricas e avaliações aproximadas baseada em outras obras similares. 
e.2) A questão VI (A previsão orçamentária para a execução da obra é adequada?) visa avaliar se foram observadas as exigências de previsão de recursos orçamentários que assegurem o pagamento dos valores contratados.

e.3) A questão VII (O tipo do empreendimento exige licença ambiental e foram realizadas todas as etapas para esse licenciamento?) se detém na análise do cumprimento do processo de licenciamento ambiental.

f) A questão IX [A formalização e a execução do convênio (ou outros instrumentos congêneres) foram adequadas?] e questão X (A formalização do contrato atendeu aos preceitos legais e sua execução foi adequada?) dizem respeito à etapa da licitação propriamente dita e a fase contratual (fiscalização).

g) A questão XIII (Questão para cadastramento de achados não típicos) foi registrada especificamente para contemplar a verificação de adequação dos projetos básicos e executivos produzidos pelo consórcio contratado aos anteprojetos que embasaram a licitação dos Lotes 3.1 e 6 da BR-381/MG, razão pela qual a referida questão seja posicionada na fase contratual, por estar vinculada a aspecto da fiscalização.

Em síntese, as questões efetuadas abrangeram três aspectos bem definidos do processo de contratação. O Anteprojeto de Engenharia com abordagens centradas no orçamento estimativo elaborado pela administração. O segundo grupo de questões foi centrado na fase da licitação e o terceiro na fase contratual, especificamente em aspectos da fiscalização.

Ademais, verifica-se que houve uma prevalência por exames de engenharia, majoritariamente a avaliação de compatibilidade de preços definidos pela administração com os valores de mercado.

Essa linha de atuação visa majoritariamente mitigar inadequações de orçamentação que podem vir a se configurar em algum tipo de vantagem financeira indevida na execução da obra.

O Quadro 4.2 sintetiza as questões por fase do processo de contratação. 


\section{Questão de Auditoria}

\section{Anteprojeto}

Os preços dos serviços definidos no orçamento da obra são compatíveis com os valores de mercado?

Os quantitativos definidos no orçamento da obra são condizentes com os quantitativos apresentados no projeto básico / executivo?

Existem estudos que comprovem a viabilidade técnica e econômico-financeira do empreendimento?

Existem estudos hidrológicos que comprovem adequadamente a viabilidade hídrica do empreendimento?

Caso a obra seja dependente do Pisf para ter funcionalidade, os cronogramas de ambas as obras estão compatíveis?

\section{Licitação}

O procedimento licitatório foi regular?

O orçamento da obra encontra-se devidamente detalhado (planilha de quantitativos e preços unitários) e acompanhado das composições de todos os custos unitários de seus serviços?

A previsão orçamentária para a execução da obra é adequada?

O tipo do empreendimento exige licença ambiental e foram realizadas todas as etapas para esse licenciamento?

\section{Fiscalização}

Questão para cadastramento de achados não típicos.

\section{Anteprojeto/Fiscalização}

Há projeto básico/executivo adequado para a licitação/execução da obra?

\section{Licitação/Fiscalização}

A formalização e a execução do convênio (ou outros instrumentos congêneres) foram adequadas?

A formalização do contrato atendeu aos preceitos legais e sua execução foi adequada?

Quadro 4.3 - questões de auditoria por fase de contratação

Fonte: Autor.

Posto isto, verificou-se que o conjunto das 67 constatações abrangeu fragilidades e inconformidades vinculadas às três fases específicas e bem distintas do processo de 
contratação anteriormente explicitadas: a) o Anteprojeto de Engenharia; b) o Processo Licitatório propriamente dito e c) a Fase Contratual, notadamente a Fiscalização.

No que tange ao Anteprojeto de Engenharia, as constatações abordam fatores do campo da técnica da engenharia ligados a fragilidades nas justificativas para a escolha da solução de engenharia e na estimação dos custos, inclusive com registros de sobrepreço.

As constatações referentes ao Processo Licitatório vincularam-se a aspectos procedimentais que devem fazer parte do edital, especialmente aspectos formais e legais. Exemplificativamente cita-se: cláusulas do edital em desacordo com a legislação e critérios inadequados de habilitação e julgamento.

Quanto à Fiscalização, as constatações envolveram deficiências ou omissões na fase contratual que ocasionaram descumprimento de prazos com atrasos injustificáveis e aceitação de projetos em desconformidade com as premissas do anteprojeto e do edital.

O detalhamento do percentual das constatações por fase de contratação é apresentado na Tabela 4.7, a seguir.

Tabela 4.7 - Percentual das constatações por fase de contratação

\begin{tabular}{c|c|c}
\hline \multicolumn{1}{c|}{ Fase de Contratação } & $\begin{array}{c}\text { Quantidade de } \\
\text { Constatações }\end{array}$ & Percentual \\
\hline Anteprojeto de Engenharia & 28 & $42 \%$ \\
\hline Processo Licitatório & 24 & $36 \%$ \\
\hline Fiscalização & 15 & $22 \%$ \\
\hline \multicolumn{1}{c|}{ TOTAL } & $\mathbf{6 7}$ & $\mathbf{1 0 0 \%}$ \\
\hline
\end{tabular}

Fonte: Autor.

Depreende-se da tabela que as fragilidades referentes ao Anteprojeto de Engenharia representam a maioria das impropriedades identificadas pelo TCU nos empreendimentos licitados na modalidade contratação integrada. Ademais, praticamente um terço das constatações é referente ao processo licitatório e aproximadamente $20 \%$ é referente a aspectos da fiscalização desses empreendimentos.

À exceção de duas constatações envolvendo fragilidades sobre a salvaguarda de documentos sigilosos, todas as demais constatações referentes ao Processo Licitatório não serão objeto desta avaliação por estarem diretamente associadas a questões e diretrizes 
operacionais vinculadas ao estabelecimento de regras para a estruturação da licitação, tais como regras para a contratação, regras para a habilitação dos interessados, regras para o julgamento das propostas.

Para fins de registro, o conjunto dessas 24 constatações é apresentado na Tabela 4.8.

Tabela 4.8 - Constatações referentes ao Processo Licitatório

\begin{tabular}{|c|c|}
\hline Constatação & $\begin{array}{c}\mathbf{N}^{\circ} \text { de } \\
\text { constatações }\end{array}$ \\
\hline $\begin{array}{l}\text { Restrição à competitividade da licitação decorrente de critérios inadequados de habilitação } \\
\text { e julgamento }\end{array}$ & 5 \\
\hline Adoção de regime de execução contratual inadequado ou antieconômico & 4 \\
\hline Critério de julgamento inadequado em licitação regida pelo RDC & 2 \\
\hline $\begin{array}{l}\text { Motivação deficiente e/ou viciada do ato de escolha do regime da contratação integrada do } \\
\text { RDC }\end{array}$ & 2 \\
\hline Ausência de aprovação do edital e seus anexos pelo órgão concedente & 1 \\
\hline $\begin{array}{l}\text { A descrição do objeto no termo do convênio não coincide com a descrição do objeto da } \\
\text { licitação }\end{array}$ & 1 \\
\hline $\begin{array}{l}\text { Ausência, insuficiência ou previsão ilimitada de recursos orçamentários para a execução da } \\
\text { obra no ano }\end{array}$ & 1 \\
\hline $\begin{array}{l}\text { Critério de julgamento da proposta técnica baseada apenas em experiência profissional da } \\
\text { licitante e de sua equipe técnica }\end{array}$ & 1 \\
\hline $\begin{array}{l}\text { Cláusulas do edital/contrato em desconformidade com os preceitos da legislação relativa ao } \\
\text { RDC }\end{array}$ & 1 \\
\hline $\begin{array}{l}\text { Frustração ao caráter competitivo do certame por violação ao princípio da isonomia entre } \\
\text { os licitantes }\end{array}$ & 1 \\
\hline Obra de grande vulto não constitui projeto orçamentário específico no nível de título. & 1 \\
\hline $\begin{array}{l}\text { Ausência de processo administrativo para elaboração e aprovação do anteprojeto de } \\
\text { engenharia }\end{array}$ & 1 \\
\hline Ausência de regulamentação do trâmite e do controle de documentos sigilosos & 1 \\
\hline $\begin{array}{l}\text { Edital não contempla os requisitos mínimos exigidos pela legislação do Regime } \\
\text { Diferenciado de Contratação }\end{array}$ & 1 \\
\hline $\begin{array}{l}\text { A obra não possui o Certificado de Avaliação da Sustentabilidade da Obra Hídrica (Certoh) } \\
\text { emitido pela Agência Nacional de Águas (ANA) }\end{array}$ & 1 \\
\hline TOTAL & 24 \\
\hline
\end{tabular}

Fonte: Autor.

As constatações Ausência de processo administrativo para elaboração e aprovação do anteprojeto de engenharia e Ausência de regulamentação do trâmite e do controle de documentos sigilosos advêm do Relatório de Fiscalização - Resumido n ${ }^{\circ}$ 53/2014 referente à obra de pavimentação da BR-316/AL, aguardando apreciação pelo TCU. 
Para fins de registro, importa ressaltar que o TCU entendeu que o sigilo do orçamento no âmbito do RDC é uma faculdade do gestor e não uma obrigação (voto condutor do Acórdão 3011/2012-TCU-Plenário e voto condutor do Acórdão 306/2013-TCU-Plenário).

No outro ponto, o grupo de constatações que diz respeito à fase de fiscalização do contrato compreende 15 registros, a seguir apresentadas na Tabela 4.9.

Tabela 4.9 - Constatações referentes à Fiscalização

\begin{tabular}{|c|c|}
\hline Constatação & $\begin{array}{c}\mathbf{N}^{\circ} \text { de } \\
\text { constatações }\end{array}$ \\
\hline Fiscalização ou supervisão deficiente ou omissa & 3 \\
\hline Fragilidade ou deficiência na execução de contratos do RDC & 2 \\
\hline Projeto básico deficiente ou desatualizado & 2 \\
\hline Duplicidade na contratação/Licitação de serviços & 2 \\
\hline Descumprimento de cláusulas contratuais & 1 \\
\hline $\begin{array}{l}\text { Descumprimento do prazo para entrega, análise ou aprovação do projeto executivo } \\
\text { apresentado pela contratada no RDC Contratação Integrada }\end{array}$ & 1 \\
\hline Existência de atrasos injustificáveis nas obras e serviços & 1 \\
\hline Projeto executivo deficiente ou desatualizado & 1 \\
\hline $\begin{array}{l}\text { Projeto Executivo (RDC Contratação Integrada) em desconformidade com as premissas do } \\
\text { anteprojeto e do edital da licitação }\end{array}$ & 1 \\
\hline $\begin{array}{l}\text { Inobservância dos requisitos legais e técnicos de acessibilidade de pessoas portadoras de } \\
\text { deficiência ou com mobilidade reduzida }\end{array}$ & 1 \\
\hline TOTAL & 15 \\
\hline
\end{tabular}

Fonte: Autor.

As constatações apontadas nesse grupo constituem exemplos da falta de adequada supervisão/fiscalização visto que estão todas relacionadas a descumprimentos de disposições contratuais técnicas e administrativas em todos os seus aspectos, especialmente relacionadas às inobservâncias do prazo e qualidade dos projetos de engenharia que foram fornecidos pelas empresas contratadas.

Por fim, as impropriedades referentes ao Anteprojeto de Engenharia totalizam 28 constatações e estão presentes em 16 dos 18 empreendimentos fiscalizados.

Levando em consideração que as impropriedades relacionadas à fiscalização do contrato também foram decorrentes de fragilidades do campo da técnica da engenharia, tem-se que 
esse conjunto totaliza praticamente dois terços de todos os registros efetuados pelo TCU em empreendimentos licitados na modalidade contratação integrada.

As obras do Ramal do Entremontes/PE e da Dragagem do Porto de Santos/SP foram as únicas que não tiveram constatação referente ao Anteprojeto de Engenharia.

Em relação ao conjunto de 28 registros sobre o Anteprojeto de Engenharia, a constatação Fragilidade ou deficiência na fase preparatória de licitação do RDC foi à que teve a maior incidência, sendo observada em 8 empreendimentos.

Os aspectos discutidos nessa constatação abrangeram em dois empreendimentos inconsistências no orçamento estimativo e nos outros seis empreendimentos eminentemente fatores relacionados às fragilidades do gerenciamento de riscos, tais como ausência de matriz de risco e impropriedades relativas ao cálculo da remuneração de risco, além de impropriedades relativas à garantia contratual e ao seguro risco de engenharia

A Tabela 4.10 apresenta as constatações vinculadas ao Anteprojeto de Engenharia.

Tabela 4.10 - Constatações referentes ao Anteprojeto de Engenharia

\begin{tabular}{l|c}
\hline \multicolumn{1}{c|}{ Constatação } & $\begin{array}{c}\mathbf{N}^{\circ} \text { de } \\
\text { constatações }\end{array}$ \\
\hline Fragilidade ou deficiência na fase preparatória de licitação do RDC & 8 \\
\hline Sobrepreço decorrente de preços excessivos frente ao mercado & 6 \\
\hline Quantitativos inadequados na planilha orçamentária & 4 \\
\hline Anteprojeto de engenharia deficiente e/ou desatualizado & 2 \\
\hline Critério de medição inadequado ou incompatível com o objeto real pretendido & 2 \\
\hline $\begin{array}{l}\text { Estimativa do custo total de investimento deficiente } \\
\text { Ausência de licitação autônoma para aquisição de equipamentos e/ou materiais, embora } \\
\text { técnica e economicamente recomendável. }\end{array}$ & 2 \\
\hline $\begin{array}{l}\text { Parcelamento inadequado, gerando restrição à competitividade ou prejuízo à Administração } \\
\text { por perda de economia de escala }\end{array}$ & 1 \\
\hline $\begin{array}{l}\text { Metodologia utilizada para definição do orçamento e preço de referência deficiente e/ou } \\
\text { inadequada }\end{array}$ & 1 \\
\hline \begin{tabular}{l} 
Publicação de edital de licitação sem prévia definição do orçamento e preço de referência \\
\hline
\end{tabular} & 1 \\
\hline
\end{tabular}

Fonte: Autor. 
O grande número de constatações sobre inadequações do Anteprojeto de Engenharia demonstra de modo objetivo que houve um deslocamento das constatações que no âmbito da Lei ${ }^{\circ} 8.666 / 93$ antes estavam vinculadas ao Projeto Básico ou Executivo.

Com exceção da constatação de maior recorrência, todas as demais não diferiram dos aspectos tradicionalmente delineados em constatações vinculadas a empreendimentos licitados pela Lei ${ }^{\circ} 8.666 / 93$.

Feitas essas explanações, passa-se especificamente para a análise das constatações vinculadas aos novos temas associados a esses certames.

Conforme mencionado, em apenas 6 empreendimentos, um terço do montante fiscalizado, foram feitas registros concernentes ao tema gestão de riscos ou seguros e garantias.

Desse total, cinco fiscalizações referem-se ao DNIT e uma à Infraero.

Importa destacar o seguinte fato marcante, não há questão de auditoria específica abordando aspectos relacionados à gestão de risco ou seguros e garantias, de modo que todas as constatações foram desenvolvidas tendo como referências as mesmas questões de auditoria aplicadas aos empreendimentos licitados pela Lei ${ }^{\circ} 8.666 / 93$.

Um total de cinco acórdãos e cinco relatórios de auditoria (dos quais três ainda pendentes de apreciação pelo TCU) abordam o tema gestão de risco e seguros/garantias, conforme apresentado no Quadro 4.4.

Para fins de melhor visualização, a referência aos acórdãos do Tribunal de Contas da União está efetuada de forma simplificada, onde $\mathrm{AC}$ designa o acórdão e o $\mathrm{P}$ indica que trata-se de uma decisão do Plenário. 


\begin{tabular}{|c|c|c|c|}
\hline $\begin{array}{l}\text { Referência do } \\
\text { Empreendimento }\end{array}$ & $\begin{array}{c}\text { Gestão } \\
\text { de } \\
\text { Riscos }\end{array}$ & $\begin{array}{l}\text { Seguros e } \\
\text { Garantias }\end{array}$ & Relatórios de Fiscalização e Acórdãos de referência \\
\hline \multicolumn{4}{|l|}{ DNIT } \\
\hline $\begin{array}{l}\text { BR-163/MT - } \\
\text { Pavimentação }\end{array}$ & $\mathrm{X}$ & $\mathrm{X}$ & AC 1465/2013-P \\
\hline $\begin{array}{l}\text { BR-163/PA - } \\
\text { Pavimentação }\end{array}$ & $\mathrm{X}$ & $\mathrm{X}$ & $\begin{array}{l}\text { Relatório } \mathrm{n}^{\circ} 1399 / 2012 \text { - AC 1310/2013-P } \\
\text { Relatório } \mathrm{n}^{\circ} 24 / 2104 \text { - ainda não apreciado pelo } T C U\end{array}$ \\
\hline $\begin{array}{l}\text { BR-381/MG - } \\
\text { Duplicação }\end{array}$ & $\mathrm{X}$ & $\mathrm{X}$ & Relatório $\mathrm{n}^{\circ} 1361 / 2012$ - ainda não apreciado pelo $T C U$ \\
\hline $\begin{array}{l}\text { Programa BR-Legal - } \\
\text { Sinalização Viária }\end{array}$ & & $\mathrm{X}$ & AC 2011/2015-P \\
\hline Porto de Manaus/AM & & $\mathrm{X}$ & $\begin{array}{l}\text { Relatório } \mathrm{n}^{\circ} 303 / 2013-\mathrm{AC} 2745 / 2013-\mathrm{P} \\
\text { Relatório } \mathrm{n}^{\circ} 32 / 2014 \text { - ainda não apreciado pelo } T C U\end{array}$ \\
\hline \multicolumn{4}{|l|}{ Infraero } \\
\hline $\begin{array}{l}\text { TPS do Aeroporto } \\
\text { Afonso Pena/PR }\end{array}$ & $\mathrm{X}$ & & AC 1510/2013-P \\
\hline
\end{tabular}

Quadro 4.4 - Relatórios de Fiscalização e Acórdãos que abordam o tema gestão de riscos e seguros e garantias

Fonte: Autor.

Para fins de melhor compreensão, a abordagem é efetuada por tema e não por empreendimento.

O tema gestão de riscos foi somente abordado em quatro empreendimentos e a partir da análise do teor dos registros verifica-se que em três a abordagem foi destacando à ausência de matriz de riscos no instrumento convocatório.

Nessas avaliações, a argumentação do TCU destacou a importância da matriz de riscos como informação indispensável para a caracterização do objeto e das respectivas responsabilidades contratuais.

O Acórdão 1310/2013-TCU-Plenário, de 29/5/2013, foi a primeira deliberação do TCU que abordou a importância da matriz de riscos na contratação integrada e fez recomendação ao DNIT de previsão da referida matriz em suas próximas licitações. Exatamente na mesma linha, o Acórdão 1465/2013-TCU-Plenário, de 12/6/2013, fez recomendação similar ao DNIT. 
O TCU ao avaliar as obras do aeroporto Afonso Pena em Curitiba se valeu da recente experiência do julgamento dos Acórdãos 1310/2013 e 1465/2013 para definir a matriz de riscos como elemento essencial e obrigatório do anteprojeto de engenharia, por meio do Acórdão 1510/2013-TCU-Plenário, de 19/6/2013.

Em síntese, observou-se que a matriz de risco não foi compreendida pelos órgãos como um instrumento de gestão dos riscos e revisão dos contratos, tanto que somente passou a ser utilizada a partir de determinação imposta pelo Tribunal de Contas da União, por meio do Acórdão 1510/2013-TCU-Plenário.

Importa destacar que a ausência de conhecimento por parte da equipe projetista/orçamentista de um anteprojeto sobre quem irá suportar as repercussões financeiras decorrentes de possíveis eventos supervenientes durante a execução de um contrato de obra fragiliza as análises e aumenta o grau de imprecisão da estimação, dentre outras questões.

Uma vez que o Decreto $n^{\circ} 7.581 / 2013$ é de 11/10/2011, registra-se que a verificação da recorrência da ausência da matriz de risco nos certames decorrido mais de um ano e meio da vigência do regime de contratação integrada é um fato marcante, dado que a elaboração da matriz está inserida na primeira etapa no processo de gerenciamento de risco e a sua ausência acarreta a não realização de todas as demais etapas.

O quarto empreendimento em que foi efetuada a avaliação da gestão de risco foi a BR381/MG. O Relatório n 1361/2012 (ainda não apreciado pelo TCU) aborda tecnicamente de modo muito consistente 5 impropriedades relativas à metodologia de cálculo da remuneração de riscos do DNIT, a seguir apresentadas:

- Pontos passíveis de questionamento na base de dados utilizada na metodologia;

- Consideração em duplicidade da incerteza na metodologia;

- Ausência de critérios objetivos e formalmente estabelecidos para definição do cenário de risco a ser adotado para o empreendimento;

- Ausência critérios objetivos e formalmente estabelecidos para seleção das obras que serão objeto de análise de risco; e

- Ausência de consideração de características específicas do empreendimento. 
Destaca-se que toda avaliação realizada está vinculada a fase de análise quantitativa do processo de gerenciamento de risco.

Assim, conforme exposto, verifica-se que a avaliação do TCU se concentrou na abordagem de duas fases do processo de gerenciamento de risco: i) a fase de identificação dos riscos, essencialmente a detecção da ausência da matriz de riscos e ii) a fase de análise quantitativa dos riscos mediante contribuições à metodologia do DNIT para cálculo da reserva de contingência.

No que concerne aos Seguros e Garantias, as avaliações do TCU se concentraram sobre questões vinculadas ao seguro de risco de engenharia e ao maior grau de exigência da garantia prestada pelo contratado.

O Relatório n 1361/2012 (ainda não apreciado pelo TCU), o Acórdão 1310/2013-TCUPlenário e Acórdão 1465/2013-TCU-Plenário fizeram ponderações sobre a necessidade do detalhamento adequado das condições de contratação do seguro risco de engenharia.

Já o Relatório $n^{\circ}$ 24/2014 (ainda não apreciado pelo TCU) registrou falhas no processo de fiscalização do cumprimento da exigência de contratação do seguro risco de engenharia, visto que as apólices protocoladas pelo consórcio contratado não satisfazem as exigências do edital.

Em relação à Garantia, o Relatório n ${ }^{\circ}$ 1361/2012 (ainda não apreciado pelo TCU) pontuou a ausência de detalhamento adequado das condições de execução da garantia contratual nos casos de rescisão, uma vez que não foram definidos a extensão dos danos a serem ressarcidos.

Ademais, o Relatórios $n^{\circ} 303 / 2013$ e 32/2014 (ainda não apreciado pelo TCU) questionaram a legalidade da exigência de garantia contratual em percentual superior ao estabelecido pela Lei 8.666/93.

Sobre esse apontamento, o Ministro relator do Acórdão 2745/2013-TCU-Plenário ao avaliar o tema expôs que a contratação integrada criou um novo cenário factual e mercadológico, então não coberto pelas possibilidades então previstas pelo art. 56 da Lei de Licitações, em seu rol de garantias. Nessa linha de argumentação, considerou adequada a superação daqueles limites, desde que devidamente motivado e proporcional aos riscos assumidos. 
De acordo com todo o exposto, verifica-se que o quantitativo de fiscalizações realizadas em empreendimentos licitados na modalidade contratação integrada ainda é pouco representativo e tendo como referência a bibliografia especializada sobre o tema riscos, há um campo significativamente vasto e ainda não explorado de temas a serem enfrentados seja pelas auditorias, mas também especialmente pelos gestores.

No que tange à Fiscalização temática do Programa Proinfância do FNDE (Fiscobras 2013), destaca-se a verificação de que a licitação empregou indevidamente o regime "empreitada por preços globais", visto que, na realidade, tratava-se de registro de preços com características de uma "contratação integrada", pois a modelagem envolvia as principais características desse novo regime de execução, em especial a possibilidade de apresentação de projetos com metodologias diferenciadas de execução. Dado a característica singular dessa contratação, a referência melhor ajustada para enquadramento da mesma é o sistema de registro de preços.

Em relação as quatro fiscalizações provenientes de representações em licitações do DNIT (Fiscobras 2014) importa registrar que 2 foram julgadas improcedentes por meio dos acórdãos 4312/2014-TCU-Primeira Câmara e 273/2015-TCU-Plenário, respectivamente vinculadas aos TCs 018.683/2014 e 018.475/2014, e a fiscalização vinculada ao TC 006.289/2014 ainda não foi julgada.

A fiscalização referente ao TC 006.254/2014 trata de representação a respeito de possíveis irregularidades em licitação de obras na rodovia BR-116/BA e originou o Acórdão 1734/2015-TCU-Primeira Câmara que determinou ao DNIT a elaboração de edital padronizado concernente às licitações realizadas pelo RDC, sob o regime de contratação integrada.

Em síntese, os cinco processos destacados nos acórdãos consolidadores dos ciclos Fiscobras 2013 e 2014 não enfrentaram o tema riscos e/ou seguros e garantias.

Por fim, conclui-se a avaliação no que tange ao TCU com considerações sobre o tema sigilo, tendo como referência as considerações feitas nas Orientações FHWA (2004) tanto sobre a avaliação do grau de competição de um certame (Assessing Competition) quanto sobre a reconhecida fragilidade da manutenção do sigilo.

Conforme anteriormente apresentado, no que tange aos relatórios avaliados, o tema salvaguarda do sigilo foi somente abordado no Relatório de Fiscalização - Resumido ${ }^{\circ}$ 
53/2014 (ainda não apreciado pelo TCU) referente à obra de pavimentação da BR-316/AL, onde foram registradas as seguintes constatações: i) Ausência de processo administrativo para elaboração e aprovação do anteprojeto de engenharia e ii) Ausência de regulamentação do trâmite e do controle de documentos sigilosos.

Explicita-se que embora o tema sigilo não tenha sido abordado no Relatório de Fiscalização da dragagem do Porto de Santos/SP o mesmo foi pontuado no voto do Ministro Relator do Acórdão 1541/2014-TU-Plenário.

O Ministro Relator levando em consideração que os preços finais ofertados pelos licitantes encontravam-se acima do valor estimado pela Administração e que a licitação restou fracassada, recomendou que a Secretaria de Portos da Presidência da República (SEP/PR) avaliasse nas próximas licitações a vantagem da manutenção do sigilo do valor estimado de obras uma vez que os serviços de dragagem não têm referências nos sistemas oficiais de preços (Sinapi/Sicro).

Assim como ocorreu com os temas gestão de riscos e seguros e garantias, observa-se que não há questões específicas envolvendo o tema sigilo.

Reforça-se que o TCU entendeu que o sigilo do orçamento no âmbito do RDC é uma faculdade do gestor e não uma obrigação (voto condutor do Acórdão 3011/2012-TCUPlenário e voto condutor do Acórdão 306/2013-TCU-Plenário).

Contudo, há que se alertar que a grande questão que envolve o sigilo do orçamento de referência é se, de fato, a informação será mantida sigilosa, já que isso requer um esforço de gestão que inclui treinamentos e a instituição de normativos específicos para que todos os setores do órgão nos quais tramite a informação possam assegurar a sua confidencialidade.

No que tange ao tratamento e a gestão de informações sigilosas, foi verificado que o TCU instituiu por meio da Portaria $\mathrm{n}^{\circ} 85$, de 3/4/2012, normativo para garantia dos procedimentos internos relativos ao trâmite de matérias sigilosas provenientes de licitações no âmbito do RDC. Não foi verificado em outro órgão do Poder Executivo Federal um normativo com conteúdo equivalente.

Em síntese, o baixo grau de maturidade dos órgãos sobre o tema gerenciamento de riscos teve reflexo direto nas fiscalizações empreendidas pelo TCU, tanto que o Tribunal não 
customizou questões e métodos específicos para auditar a gestão de riscos nos empreendimentos fiscalizados.

Sobre as fiscalizações efetuadas pelo TCU, verificou-se que o conjunto de empreendimentos fiscalizados é pouco significativo, visto que apenas 6 obras foram avaliadas quanto a aspectos do processo de gerenciamento de riscos, considerando os últimos quatro ciclos de fiscalização do Fiscobras, 2011 a 2014.

À título de arremate da etapa de análise crítica que antecede as diretrizes propriamente ditas, cabem algumas considerações e reflexões de caráter diagnóstico sobre o que foi observado no processo de contratação integrada brasileiro à luz do tema gerenciamento de riscos.

Em primeiro lugar, frisa-se que uma preocupação deste trabalho foi não enveredar por uma avaliação subjetiva que expressasse um juízo de valor pessoal que sobrevalorizasse ou diminuísse as iniciativas institucionais de utilização dessa nova sistemática de contratação de obras públicas.

Os possíveis erros advindos do pioneirismo da construção de uma metodologia, as restrições institucionais próprias da Administração Pública e o contexto políticoeconômico em que os certames foram realizados são questões compreendidas e levadas em consideração não para abrandar as conclusões, mas para compor as análises sobre as relações de causalidade dos erros porventura cometidos de modo que os mesmos possam ser corrigidos para doravante não ocorrerem.

Em segundo lugar, a alteração efetuada na Lei $n^{\circ} 12.462 / 2011$ para conferir autorização legal de utilização do critério de seleção unicamente pelo menor preço nas contratações integradas é incompatível com a eficiência pretendida pela utilização desse regime e a exigência de performance relatada em Yu et at (2013), Ballesteros-Pérez et al (2015) e Park et al (2015).

Em terceiro lugar é importar destacar que a inexistência de uma definição normativa-legal precisa do que caracteriza o Anteprojeto de Engenharia e qual o seu nível de precisão, aliadas com a ausência de prescrições orientativas-normativas com detalhamento de técnicas e/ou procedimentos para o cálculo da reserva de contingência urgem como questões que devem ser devidamente enfrentadas pela comunidade técnica-científica, uma vez que afetam diretamente todas as etapas seguintes do processo de gerenciamento de 
riscos e fragilizam a aplicação desse regime de contratação integrada pelos gestores assim como a sua avaliação pelos órgãos de controle.

Em quarto lugar, e não menos importante, tem-se que a transferência do ônus da elaboração do projeto para as empresas contratadas, premissa basilar da contratação integrada, traz consigo um risco inerente de insucesso aos empreendimentos, decorrente da possibilidade de ineficácia da implementação de uma gestão de riscos, uma vez que, conforme Serpella et al (2014), a mesma deve estar suportada por uma metodologia adequada, sistemática e, mais importante, conhecimento e experiência.

A contratação integrada somente irá atingir o objetivo esperado, que é a melhoria da qualidade dos projetos e consequente das obras, incluindo o cumprimento dos requisitos de custo e prazo, se a Administração Pública se concentrar no processo de gerenciamento de riscos como um todo e não apenas em alguns aspectos de poucas etapas, como de fato foi observado. Além no cumprimento de outros aspectos de gerenciamento, como os vinculados a execução propriamente dos contratos, especialmente no que tange ao acompanhamento e fiscalização pari passu o andamento dos serviços.

Essas fragilidades se não forem devidamente tratadas por meio adequadas cláusulas editalícias-contratuais e suportadas por especificações e critérios técnicos devidamente justificados nos anteprojetos poderão ensejar um significativo aumento da judicialização dos contratos, e, por conseguinte aumento do número de obras inacabadas, uma vez que os questionamentos da Administração quando da não aceitação de serviços estão adstritos às soluções de engenharia do projeto que serão de autoria do particular.

\subsection{DIRETRIZES PARA O GERENCIAMENTO DE RISCOS}

As diretrizes visam o estabelecimento de recomendações e induzir boas práticas consolidadas sobre os principais aspectos metodológicos e operacionais de gerenciamento dos riscos para o planejamento e controle de licitações efetuadas na modalidade contratação integrada.

Destaca-se que as diretrizes tem a função de ser uma ferramenta orientativa de apoio à gestão de licitações efetuadas na modalidade contratação integrada.

As diretrizes são a seguir apresentadas por tema de significância, conforme os critérios e 
parâmetros definidos na metodologia.

\section{Critérios de julgamento:}

Recomendação - Adotar preferencialmente o critério de julgamento de técnica e preço.

Considerações - após a alteração legislativa que desobrigou a adoção do critério de julgamento de técnica e preço, os órgãos contratantes passaram a pautar suas licitantes pelo critério de menor preço, implicando em uma desfiguração do modelo brasileiro em relação às referências internacionais.

Idealmente, os critérios técnicos devem avançar para critérios de desempenho passado e histórico de sucesso dos contratantes.

Referência - Cibinic et al (2011), Relatório NCHRP 561 (2006), Síntese NCHRP 390 (2009) e Gransberg e Shane (2015).

\section{Nível de precisão da estimativa de custo paradigma da Administração:}

Recomendação - Estabelecer uma métrica referencial para avaliar o nível de precisão da estimativa de custo paradigma com base nos resultados dos certames realizados.

Considerações - De acordo com as Orientações FHWA (2004), a estimativa final de custo da Adminsitração é adequada quando está dentro da faixa de até $10 \%$ do preço mais baixo para, pelo menos, $50 \%$ dos projetos contratados.

Referência - Orientações FHWA (2004), Guidelines on Preparing Engineer's Estimate, Bid Reviews and Evaluation.

\section{Grau de competicão de um certame:}

Recomendação - Estabelecer um parâmetro de avaliação do grau de competição das licitações.

Considerações - De acordo com as Orientações FHWA (2004), a concorrência deve ser considerada excelente quando existem seis ou mais lances dentro do intervalo de até $20 \%$ a mais do menor preço.

Referência - Orientações FHWA (2004), Guidelines on Preparing Engineer's Estimate, Bid Reviews and Evaluation. 


\section{Sigilo do valor da estimativa de custo paradigma da Administracão:}

Recomendação - Preferencialmente divulgar o valor da estimativa de custo paradigma da Administração.

Considerações - Considera-se mais efetivo a divulgação do valor da estimativa de custo paradigma da Administração do que estabelecer uma classificação de referência para as estimativas de custos referência da Administração brasileira nos moldes das Orientações FHWA (2004).

Referência - Orientações FHWA (2004), Guidelines on Preparing Engineer's Estimate, Bid Reviews and Evaluation.

\section{Planejamento do gerenciamento dos riscos:}

Recomendação - Instituir um plano de gerenciamento dos riscos que especifique como as atividades de gerenciamento dos riscos serão estruturadas e executadas.

Considerações - O plano de gerenciamento dos riscos é um componente do plano de gerenciamento do projeto, de modo que a sua ausência desconfigura e compromete todo o esforço de gerenciamento empreendido.

Referência - Modelos de gerenciamento de projetos e riscos: Guia PMBOK (2013), PRINCE2 (2009) e os normativos da International Organization for Standardization ISO.

\section{Identificação dos riscos:}

Recomendação - Abordar no processo de categorização os riscos sistêmicos, riscos específicos do projeto e, conforme o caso, riscos secundários.

Considerações - o método a ser utilizado para a precificação do risco está relacionado com o tipo de risco. Exemplificativamente, a análise de simulação de risco por contar com a prática de estimativa mais determinística deve ser limitada a riscos específicos de projeto, ao passo que métodos paramétricos são geralmente para os riscos sistêmicos.

Referência - os princípios gerais obrigatórios que devem ser abordados quando do cálculo da contingência apresentados na RP 40R-08 (2008) e RP 42R-09 (2009). 


\section{Realizacão da análise qualitativa dos riscos:}

Recomendação - Identificar os riscos de acordo com a magnitude do efeito no custo, conforme o nível de maturidade do orçamento.

Considerações - a chave para a realização de uma análise de risco do projeto está na correta identificação dos itens que podem ter um efeito crítico sobre os resultados do projeto e na aplicação de escalas para esses itens e só a esses itens.

É da natureza humana assumir, por exemplo, que um grande item em uma estimativa de custo é crítico simplesmente por causa de sua magnitude. Isso não é o caso. Um item é crítico apenas se ele puder mudar o suficiente para ter um efeito significativo sobre o custo.

Referência - prática recomendada RP 41R-08 (2008) e as matrizes de classificação de estimativas de custos das práticas recomendadas RP 17R-97(2011), RP 18R-97(2011) e a RP 56R-08(2012).

\section{Realizacão da análise quantitativa dos riscos:}

Recomendação - Fundamentar os níveis de apetite ao risco e o critério utilizado para definir a função densidade de probabilidade adotada.

Considerações - o nível de apetite ao risco estabelecido deve ser devidamente fundamento para cada licitação, tendo em vista que quanto maior o apetite maior o excesso de contingência e consequentemente maior o custo do empreendimento.

A simulação de Monte Carlo exige a identificação correta da função distribuição de probabilidade para cada item crítico. O emprego errado da função distorce a análise.

Referência - prática recomendada RP 41R-08 (2008).

\section{Planejamento das respostas aos riscos:}

Recomendação - Estabelecer requisitos para a definição do percentual de garantia contratual tendo como referência os riscos associados por empreendimento.

Considerações - a nova regulamentação relativa aos contratos de seguro-garantia, instituída pela Circular SUSEP $n^{\circ}$ 477, de 30 de setembro de 2013, exige da Administração Pública a normatização de procedimentos para o efetivo acompanhamento 
das apólices, especialmente no que tange ao estabelecimento de prazos e identificação dos responsáveis para notificação da seguradora nos casos de expectativa, reclamação e caracterização de sinistros, de acordo os riscos associados por empreendimento.

Referência - Acórdão 2745/2013-TCU-Plenário e Acórdão 2011/2015-TCU-Plenário.

\section{Controle dos riscos:}

Recomendação - Avaliar a eficácia do processo de gerenciamento de riscos, como parte integrante do plano de gerenciamento de riscos.

Considerações - as fases do processo de gerenciamento de riscos constituem um processo iterativo e incremental em que o controle desempenha o papel de estudar o resultado obtido e compara-o com resultado esperado.

Referência - Modelos de gerenciamento de projetos e riscos: Guia PMBOK (2013), PRINCE2 (2009) e os normativos da International Organization for Standardization ISO. 


\section{CONCLUSÃO}

Neste capítulo apresentam-se as conclusões obtidas do desenvolvimento desta pesquisa quanto ao cumprimento dos objetivos propostos e também as sugestões para trabalhos futuros.

O objetivo principal do trabalho foi consolidar e analisar criticamente os principais aspectos observados sobre o tema gerenciamento de riscos em diretrizes que fomentem o aprimoramento da gestão pública por meio de contribuições ao planejamento de licitações efetuadas na modalidade contratação integrada.

Em busca desse objetivo principal, os seguintes objetivos específicos foram atingidos:

i) Elaborar um instrumento (matriz) de avaliação do nível de maturidade dos órgãos em relação ao gerenciamento de riscos tendo como métrica as inovações instituídas no arcabouço legal e jurisprudencial de contratação de obras públicas;

ii) Avaliar as metodologias de precificação de riscos em relação aos níveis de maturidade instituídos pelos órgãos da Administração Pública Federal com base em um modelo referencial de gerenciamento de projetos e riscos e nas práticas internacionais de contratação e avaliação de contingências; e

iii) Identificar se as fiscalizações realizadas pelo Tribunal de Contas da União no âmbito do programa permanente de auditorias em obras e serviços de engenharia Fiscobras, desde 2011, ano em que foi instituído o regime de contratação integrada até 2014 foram focadas no tema gerenciamento de riscos.

\subsection{CONCLUSÕES OBTIDAS}

As conclusões são apresentadas tendo como referência os objetivos específicos, uma vez que os mesmos são desdobramentos do objetivo geral.

No que tange ao primeiro objetivo especifico, foram elaboradas duas matrizes de avaliação do nível de maturidade dos órgãos em relação ao gerenciamento de riscos tendo como métrica as inovações instituídas no arcabouço legal e jurisprudencial de contratação de obras públicas. 
A primeira métrica possibilita a avaliação em relação às fases de identificação e análise quantitativa de riscos, enquanto que a segunda possibilita a avaliação em relação à fase de planejamento de respostas aos riscos.

Um conjunto de 10 órgãos da Administração Pública Federal foram avaliados segundo as métricas elaboradas.

Quanto ao segundo objetivo específico, foram realizadas avaliações das metodologias de precificação de riscos do DNIT e do Ministério da Integração Nacional, as únicas duas metodologias instituídas no âmbito da Administração Pública Federal até o momento desta pesquisa.

Os resultados obtidos das avaliações das metodologias foram determinantes para a formulação das diretrizes tendo em vista que a adequabilidade das mesmas é função da sua aplicabilidade.

Assim foi verificado que os resultados da avaliação de maturidade do DNIT anteriormente realizada não se mantiveram quando da avaliação específica de sua metodologia. Mais insipiente ainda foram os resultados da avaliação da metodologia do Ministério da Integração Nacional.

Já em relação ao terceiro objetivo especifico foi verificado que o baixo grau de maturidade dos órgãos sobre o tema gerenciamento de riscos teve reflexo direto nas fiscalizações empreendidas pelo TCU, tanto que o Tribunal não customizou questões e métodos específicos para auditar a gestão de riscos nos empreendimentos fiscalizados.

Uma vez alcançados os objetivo específicos, o objetivo principal foi atingido mediante a consolidação dos principais aspectos observados nas etapas anteriores.

\subsection{SUGESTÕES PARA TRABALHOS FUTUROS}

Como propostas de estudos futuros para complementação dessa pesquisa:

1. Sugere-se monitorar se os órgãos da Administração Pública Federal de fato seguiram as diretrizes objetivando a realização de avaliações de impacto quanto a efetividade das mesmas; 
2. Sugere-se que os empreendimentos objeto das 50 licitações que foram homologadas na contratação integrada entre 2011 e 2014 sejam avaliados quando concluídos em relação ao cumprimento dos parâmetros de custo e cronograma;

3. Segure-se a continuidade dos levantamentos de licitações e deliberações do Tribunal de Contas da União em relação à contratação integrada, visando ampliar o universo de cada um desses conjuntos, constituindo-se com isso um repositório permanente de dados sobre o tema;

4. Por fim, sugere-se um aprofundamento do estudo, principalmente comparativamente em relação a vantajosidade da contratação integrada com os demais regime de execução. 


\section{REFERÊNCIAS BIBLIOGRÁFICAS}

AACE INTERNATIONAL. RP 10S-90: Cost Engineering Terminology. Morgantown: 2013.

. RP 17R-97: Cost Estimate Classification System. Morgantown: 2011.

RP 18R-97: Cost Estimate Classification System - as Applied in Engineering,

Procurement, and Construction for the Process Industries. Morgantown: 2011.

. RP 40R-08: Contingency Estimating - General Principles. Morgantown:

2008.

. RP 41R-08: Risk Analysis and Contingency Determination Using Range

Estimating. Morgantown: 2008.

. RP 42R-08: Risk Analysis and Contingency Determination Using Parametric Estimating. Morgantown: 2009.

.RP 43R-08: Risk Analysis and Contingency Determination Using Parametric Estimating - Example Models as Applied for the Process Industries. Morgantown: 2011.

. RP 44R-08: Risk Analysis and Contingency Determination Using Expected Value. Morgantown: 2012.

RP 56R-08: Cost Estimate Classification System - As applied for the Building and General Construciton Industries. Morgantown: 2012.

RP 57R-09: Integrated Cost and Schedule Risk Analysis using Monte Carlo

Simulation of a CPM Model. Morgantown: 2011.

ALtOUNIAN, C. S. Obras Públicas: Licitação, Contratação, Fiscalização e

Utilização. 4 ed. rev. atual. e ampl. Belo Horizonte: Fórum, 2014.

ASSOCIAÇÃO BRASILEIRA DE NORMAS TÉCNICAS, ABNT. NBR 13.531: 1995

- Elaboração de projetos de edificações - Atividades técnicas. Rio de Janeiro, 1995.

. NBR 13.532: 1995 - Elaboração de projetos de edificações - Arquitetura. Rio de Janeiro, 1995. 
NBR ISO 31.000: Gestão de riscos - Princípios e Diretrizes. Rio de Janeiro, 2009.

. NBR ISO/IEC 31.010: Gestão de riscos - Técnicas para o processo de avaliação de riscos. Rio de Janeiro, 2012.

. NBR ISO 21500: Orientações sobre gerenciamento de projeto. Rio de Janeiro, 2012.

ASTM E2516-11. Standard Classification for Cost Estimate Classification System. West Conshohocken, 2011.

BAETA, A. P. Regime Diferenciado de Contratações Públicas: aplicado às Licitações e Contratos de Obras Públicas. 2 ed. rev. atual. e ampl. Belo Horizonte: Fórum, 2014.

BALLESTEROS-PÉREZ, P.; CAMPO-HITSCHFELDB, M. L. DEL; , MORAMELIÀ, D.; DOMÍNGUEZ, D. Modeling bidding competitiveness and position performance in multi-attribute construction auctions. Operations Research Perspectives, Volume 2, December 2015, Pages 24-35.

BRASIL. Lei n.o 8.666, de 21 de junho de 1993 (e alterações posteriores). Regulamenta o art. 37, inciso XXI, da Constituição Federal, institui normas para licitações e contratos da Administração Pública. Disponível em: <http://www.planalto.gov.br/ccivil_03/Leis/L8666cons.htm>. Acesso em: 15. Ago 2015.

. Lei n.o 8.987, de 13 de fevereiro de 1995 (e alterações posteriores). Dispõe sobre o regime de concessão e permissão da prestação de serviços públicos previsto no art. 175 da Constituição Federal. Disponível em: <http://www.planalto.gov.br/ccivil_03/LEIS/L8987cons.htm>. Acesso em: 15. Ago. 2015.

. Lei n.o 9.074, de 7 de julho de 1995 (e alterações posteriores). Estabelece normas para outorga e prorrogações das concessões e permissões de serviços públicos. Disponível em: <http://www.planalto.gov.br/ccivil_03/Leis/L9074cons.htm>. Acesso em: 15. Ago. 2015. 
Lei n.o 11.079, de 30 de dezembro de 2004 (e alterações posteriores). Institui normas gerais para licitação e contratação de parceria público-privada no âmbito da administração pública. Disponível em:

<http://www.planalto.gov.br/ccivil_03/_ato2004-2006/2004/lei/111079.htm>. Acesso em: 15. Ago. 2015.

. Lei n.o 12.462, de 4 de agosto de 2011 (e alterações posteriores). Institui o Regime Diferenciado de Contratações Públicas. Disponível em: <http://www.planalto.gov.br/ccivil_03/_ato2011-2014/2011/Lei/L12462.htm>. Acesso em: 15. Ago 2015.

. Decreto n.o 2.745, de 24 de agosto de 1998. Aprova o Regulamento do Procedimento Simplificado da Petróleo Brasileiro S.A. - PETROBRAS previsto no art. 67 da Lei n.o 9.478, de 6 de agosto de 1997. Disponivel em: <http://www.planalto.gov.br/ccivil_03/decreto/d2745.htm>. Acesso em: 15. Ago 2015. . Decreto n.o 7.581, de 11 de outubro de 2011 (e alterações posteriores).

Regulamenta o Regime Diferenciado de Contratações Públicas - RDC, de que trata a Lei n.o 12.462, de 4 de agosto de 2011. Disponível em: <http://www.planalto.gov.br/ccivil_03/_ato2011-2014/2011/Decreto/D7581.htm>. Acesso em: 15. Ago 2015.

. Decreto n.o 7.983, de 8 de abril de 2013. Estabelece regras e critérios para elaboração do orçamento de referência de obras e serviços de engenharia, contratados e executados com recursos dos orçamentos da União. Disponível em: <http://www.planalto.gov.br/ccivil_03/_Ato2011-2014/2013/Decreto/D7983.htm>. Acesso em: 15. Ago 2015.

. Medida Provisória n.o 630, de 24 de dezembro de 2013. Altera a Lei

n.o 12.462, de 4 de agosto de 2011, que institui o Regime Diferenciado de Contratações Públicas - RDC. Disponível em:

<http://www.planalto.gov.br/ccivil_03/_ato20112014/2013/mpv/mpv630impressao.htm>. Acesso em: 15. Ago 2015.

. Ministério da Integração Nacional. Portaria n 118, de 18 de março de 2014. Brasília, 2014. 
BAETA, A. P. Orçamento e Controle de Preços de Obras Públicas. 1.ed. São Paulo: Pini, 2012.

. Regime Diferenciado de Contratações Públicas: aplicado às licitações e contratos de obras públicas. $2^{\text {a }}$ ed. São Paulo: Pini, 2014.

. Calculando contingências em orçamentos de obras públicas utilizando simulações de Monte Carlo - estudo do caso do orçamento de uma quadra poliesportiva. Maio 2014,b. Disponível em: <http://www.ibraop.org.br/artigos/xvisinaop-iv-oficina-internacional/media/sinaop/16_sinaop/apenas/ap/ Calculando_Contingencias_orcamentos_obras_simulacao_MonteCarlo.pdf $>$. Acesso em: 15. Ago 2015.

BITTENCOURT, S. Licitação através do Regime Diferenciado de Contratações. Belo Horizonte: Fórum, 2012.

BUCKER, M.B., Gerenciamento de Conflitos, Prevenção e Solução de Disputas em Empreendimentos de Construção Civil. Dissertação, Escola Politécnica da Universidade de São Paulo. Departamento de Engenharia de Construção Civil. São Paulo, 2010.

CALDEIRA, D. M., Gestão de Riscos em Obras Públicas - Perspectivas e Debates Recentes. $9^{\circ}$ Simpósio Brasileiro de Gestão e Economia da Construção, São Carlos, 2015.

CALTRANS. Project Delivery Directive PD-04 Project Contingencies and Supplemental Work - version 10/22/2009. Disponível em: < http://www.dot.ca.gov/hq/projdev/directive/PD04ProjectContingenciesSupplementalWork.pdf>. Acesso em: 15. Ago 2015. Chapter 20 - Project Development Cost Estimates, version 10/09/2014 Project Development Procedures Manual. Disponível em: <http://www.dot.ca.gov/hq/oppd/pdpm/other/PDPM-Chapters.pdf>. Acesso em: 15. Ago 2015.

CALIFORNIA DEPARTAMENT OF TRANSPORTATION, Caltrans. Project Risk Management Handbook: A Scalable Approach. Sacramento, 2012. 
CAMMAROSANO, M.; DAL POZZO, A. N.; VALIM, R. (Coordenadores). Regime Diferenciado de Contratações Públicas - RDC (Lei $n^{o}$ 12.462/11; Decreto $n^{o}$ 7.581/11): aspectos fundamentais. 2. ed. rev., ampl. e atual. Belo Horizonte: Fórum, 2012.

CAVALCANTE, R.J.;ALTOUNIAN, C.S. RDC e Contratação Integrada na prática: 250 questões fundamentais. Belo Horizonte: Fórum, 2014.

CIBINIC J.; JOHN, R. C. N. JR; CHRISTOPHER R. Y.. Formation of Government Contracts. 4th . Washington, DC: Wolters Kluwer Law \& Business, 2011.

Conselho Federal de Engenharia e Agronomia, Confea. Resolução $n^{\circ} 361$, de 10 de dezembro de 1991. Brasília, 1991.

CURRAN, M. W. Range Estimating: Measuring Uncertainty and Reasoning with Risk, Cost Engineering, Vol. 31, no. 03, AACE International, Morgantown, 1989.

DE PAULA, J.M.P. Riscos em Obras Públicas e o Regime de Contratação Integrada. Radar: tecnologia, produção e comércio exterior / Instituto de Pesquisa Econômica Aplicada. Diretoria de Estudos e Políticas Setoriais, de Inovação, Regulação e Infraestrutura. n. 1 (abr. 2009), Brasília: Ipea, 2009.

DNIT. Guia de Gerenciamento de Riscos de Obras Rodoviárias - Fundamentos. Brasília, 2013. Instrução de Serviço/DG $n^{\circ} 01$, de 02 de janeiro de 2014. Define a metodologia e regula o processo de gerenciamento de riscos, para aplicação nas contratações integradas, com o objetivo de quantificar e remunerar os riscos que são transferidos para o contratado. Brasília, 2014.

Federal Highway Administration, FHWA. Design-Build Effectiveness Study. January, 2006. Disponível em:

<https://www.fhwa.dot.gov/reports/designbuild/designbuild.pdf > . Acesso em: 15 . Ago 2015. Guide to Risk Assessment of Allocation for Highway Construction Management, October, 2006,b. Alexandria. 
Guidelines on Preparing Engineer's Estimate, BID Reviews and Evaluation.

January, 2004. Disponível em:

<https://www.fhwa.dot.gov/programadmin/contracts/ta508046.pdf>. Acesso em: 15. Ago 2015.

FILHO, L. H. A., Elaboração de Orçamentos sob a Égide da Lei 8666/93 e do Regime Diferenciado de Contratação. Apresentação ocorrida em 23 de setembro de 2014 durante o $1^{\circ}$ Seminário de Licitações e Contratos do DNIT. Disponível em: < http://www.dnit.gov.br/noticias/seminario-discute-melhorias-nos-procedimentos-delicitacoes-e-contratos>. Acesso em: 15. Ago 2015.

FIUZA, E.P.S.; DE MEDEIROS, B.A. A Agenda Perdida das Compras Públicas: Rumo a uma Reforma Abrangente da Lei de Licitações e do Arcabouço Institucional. Texto para discussão / Instituto de Pesquisa Econômica Aplicada. Brasília, Rio de Janeiro: Ipea, 1990.

FLYVBJERG, B., From Nobel Prize to Project Management: Getting Risks Right, Project Management Journal, vol. 37, no. 3, August 2006, pp.5-15.

FORTES, F. S. D. Influência do gerenciamento de riscos no processo decisório: análise de casos. 2011. 145 f. Dissertação (mestrado) - Departamento de Engenharia Naval e Oceânica/Escola Politécnica da Universidade de São Paulo, São Paulo, 2011.

GAO, Government Accountability Office. (2009). GAO Cost Estimating and Assessment Guide. Disponível em: 〈http://www.gao.gov/new.items/d093sp.pdf>. Acesso em: 15. Ago 2015.

GÓMEZ, L. A.; COELHO, C. C. S. R.; FILHO, E. O. D.; XAVIER, S. M. T. Contratos EPC Turnkey. Florianópolis: Visual Books, 2006.

GRANSBERG, D.D,; SHANE, J.S. Defining Best Value for Construction Manager/General Contractor Projects: The CMGC Learning Curve. Journal of Management in Engineering, 2015, Vol.31(4), p.4014060(7)

Instituto Brasileiro de Auditoria de Obras Públicas, IBRAOP. Orientação Técnica OTIBR 004/2012: Precisão do Orçamento de Obras Públicas, 2012. 
JUGEND, D; BARBALHO, S. C. M.; DA SILVA, S. Gestão de Projetos: Teoria, Prática e Tendências. 1. ed. Rio de Janeiro: Elsevier, 2014.

JUNIOR, J. T. P.; DOTTI, M. R. Comentários ao RDC Integrado ao Sistema Brasileiro de Licitações e Contratações Públicas. Rio de Janeiro: Renovar, 2015.

JUSTEN FILHO, M.; PEREIRA, C. A. G. (Coordenadores). O Regime Diferenciado de Contratações Públicas (RDC): Comentários à Lei $\mathrm{n}^{\circ} 12.462$ e ao Decreto $\mathrm{n}^{\circ} 7.581$. Belo Horizonte: Fórum, 2012.

MARCONDES,F. (Organização). Direito da Construção: Estudos sobre as várias áreas do Direito aplicadas ao Mercado da Construção. São Paulo: Pini, 2014.

MARINANGELO, R.; KLEE, L. Recomendações FIDIC para orientação de contratos e projetos de obras. São Paulo: Pini, 2014.

MENDES, A. Aspectos Polêmicos de Licitações e Contratos de Obras Públicas. São Paulo: Pini, 2013.

MOREIRA, E. B.; GUIMARÃES, F. V.; A Lei de Licitação - LGL e o Regime

Diferenciado de Contratação. 1. ed. São Paulo: Malheiros Editores, 2012.

MOTTA, C. P. C.; BICALHO, A. P. N.; RDC: Contratações para as copas e jogos olímpicos: Lei $n^{\circ}$ 12.462/2011, Decreto $n^{\circ}$ 7.581/2011. Belo Horizonte: Fórum, 2012.

NATIONAL COOPERATIVE HIGHWAY RESEARCH PROGRAM (NCHRP).

Report 561: Best-Value Procurement Methods for Highway Construction Projects.Washington, DC: TRB, 2006. Synthesis 390: Performance-Based Construction Contractor Prequalification. Washington, DC: TRB, 2006.

NETO, J. F. C. Elaboração e Avaliação de Projetos de Investimento: Considerando o Risco. Rio de Janeiro: Elsevier, 2009.

OFFICE OF GOVERNMENT COMMERCE (OGC). Managing Successful Projects with PRINCE2. Londres: TSO, 2009.

PARK, J.; OJIAKO, U.; WILLIAMS, T.; CHIPULU, M.; E MARSHALL, A. Practical Tool for Assessing Best Value at the Procurement Stage of Public Building 
Projects in Korea. Journal of Management Engineering, Volume 31, Issue 5 (September 2015).

POMPERMAYER, F.M; DE PAULA, J.M.P. Considerações sobre a Alocação de Riscos no Projeto do Trem de Alta Velocidade entre Rio de Janeiro, São Paulo e Campinas. Radar: tecnologia, produção e comércio exterior / Instituto de Pesquisa Econômica Aplicada. Diretoria de Estudos e Políticas Setoriais, de Inovação, Regulação e Infraestrutura. n. 1 (abr. 2009), Brasília: Ipea, 2009.

PROJECT MANAGEMENT INSTITUTE (PMI). Um Guia do Conhecimento em Gerenciamento de Projetos (Guia PMBOK) - 5 Edição. Newtown Square: PMI, 2013.

REZENDE, R. M. de. Texto para Discussão 100. O Regime Diferenciado de Contratações Públicas: comentários à Lei n 12.462, de 2011. Brasília: Núcleo de Estudos e Pesquisas do Senado, 2011.

RIBEIRO, M. P.; JÚNIOR, M. E. P.; PRADO, L. N.. Regime Diferenciado de Contratação: Licitação de Infraestrutura para Copa do Mundo e Olimpíadas. 1. ed. São Paulo: Editora Atlas, 2012.

ROSILHO, A. J. Licitação no Brasil. 1. ed. São Paulo: Malheiros Editores, 2013. RSMEANS. Design-Build Project Delivery Market Share and Market Size Report, May 2014. Disponível em: <http://www.dbia.org/resourcecenter/Documents/rsmeansreport2014.pdf>. Acesso em: 15. Ago 2015.

SANTOS, M. W. B. dos e: TANAKA, S. Y. K. (Coordenadoras). Estudos Avançados de Direito Administrativo: Análise Comparada da Lei de Licitações. Rio de Janeiro: Elsevier, 2014.

SENNA, L. A. de S. Economia e Planejamento dos Transportes. 1. ed. Rio de Janeiro: Elsevier, 2014.

SERPELLA, A. F.; FERRADA, X.; HOWARD, R.; RUBIO, L. Risk management in construction projects: a knowledge-based approach. Procedia: Social and Behavioral Sciences 119 ( 2014 ) $653-662$.

SILVA, W. R. da. O Uso de Concorrência e de Contratação Integrada no Brasil e no Mundo. Washington, 2013. 
SUNDFELD, C. A. (Organizador). Contratações públicas e seu controle. 1. ed. São Paulo: Malheiros Editores, 2013.

SUSEP, Superintendência de Seguros Privados. Circular SUPEP n ${ }^{\circ} 419$, de 17 de janeiro de 2011. Dispõe sobre regras e critérios para operação das coberturas oferecidas em plano de seguro de Riscos de Engenharia, e dá outras providências. Disponível em:

<http://www2.susep.gov.br/bibliotecaweb/docOriginal.aspx?tipo=1\&codigo=27591>. Acesso em: 15. Ago 2015.

SUSEP, Superintendência de Seguros Privados. Circular SUSEP $n^{\circ}$ 477, de 30 de setembro de 2013. Dispõe sobre o Seguro Garantia, divulga Condições Padronizadas e dá outras providências. Disponível em: < http://www2.susep.gov.br/bibliotecaweb/docOriginal.aspx?tipo=1\&codigo=31460>. Acesso em: 15. Ago 2015.

TCU, Tribunal de Contas da União. Acórdão 325/2007-TCU-Plenário. Disponível em: <http://www.tcu.gov.br>. Acesso em: 15. Ago 2015. . Acórdão 564/2011-TCU-Plenário. Disponível em: 〈http://www.tcu.gov.br〉. Acesso em: 15. Ago 2015. Acórdão 2369/2011-TCU-Plenário. Disponível em: 〈http://www.tcu.gov.br〉. Acesso em: 15. Ago 2015. Acórdão 2382/2011-TCU-Plenário. Disponível em: 〈http://www.tcu.gov.br>. Acesso em: 15. Ago 2015.

Acórdão 2877/2011-TCU-Plenário. Disponível em: 〈http://www.tcu.gov.br〉. Acesso em: 15. Ago 2015. Acórdão 2928/2012-TCU-Plenário. Disponível em: 〈http://www.tcu.gov.br〉. Acesso em: 15. Ago 2015. . Acórdão 3011/2012-TCU-Plenário. Disponível em: 〈http://www.tcu.gov.br〉. Acesso em: 15. Ago 2015. . Acórdão 306/2013-TCU-Plenário. Disponível em: 〈http://www.tcu.gov.br>. Acesso em: 15. Ago 2015. 
Acórdão 448/2013-TCU-Plenário. Disponível em: 〈http://www.tcu.gov.br〉 . Acesso em: 15. Ago 2015.

. Acórdão 1310/2013-TCU-Plenário. Disponível em: 〈http://www.tcu.gov.br〉. Acesso em: 15. Ago 2015.

Acórdão 1465/2013-TCU-Plenário. Disponível em: 〈http://www.tcu.gov.br〉. Acesso em: 15. Ago 2015.

. Acórdão 1510/2013-TCU-Plenário. Disponível em: <http://www.tcu.gov.br>. Acesso em: 15. Ago 2015.

. Acórdão 1814/2013-TCU-Plenário. Disponível em: <http://www.tcu.gov.br〉 . Acesso em: 15. Ago 2015.

Acórdão 2019/2013-TCU-Plenário. Disponível em: 〈http://www.tcu.gov.br〉. Acesso em: 15. Ago 2015.

Acórdão 2163/2013-TCU-Plenário. Disponível em: 〈http://www.tcu.gov.br〉. Acesso em: 15. Ago 2015.

Acórdão 2164/2013-TCU-Plenário. Disponível em: 〈http://www.tcu.gov.br〉. Acesso em: 15. Ago 2015.

. Acórdão 2622/2013-TCU-Plenário. Disponível em: <http://www.tcu.gov.br>. Acesso em: 15. Ago 2015.

. Acórdão 2745/2013-TCU-Plenário. Disponível em: 〈http://www.tcu.gov.br〉 . Acesso em: 15. Ago 2015.

Acórdão 2969/2013-TCU-Plenário. Disponível em: 〈http://www.tcu.gov.br> . Acesso em: 15. Ago 2015.

Acórdão 3143/2013-TCU-Plenário. Disponível em: 〈http://www.tcu.gov.br〉. Acesso em: 15. Ago 2015.

Acórdão 1167/2014-TCU-Plenário. Disponível em: 〈http://www.tcu.gov.br>. Acesso em: 15. Ago 2015. 
Acórdão 1399/2014-TCU-Plenário. Disponível em: 〈http://www.tcu.gov.br〉. Acesso em: 15. Ago 2015.

. Acórdão 1439/2014-TCU-Plenário. Disponível em: 〈http://www.tcu.gov.br〉. Acesso em: 15. Ago 2015.

Acórdão 1541/2014-TCU-Plenário. Disponível em: 〈http://www.tcu.gov.br〉. Acesso em: 15. Ago 2015.

. Acórdão 1671/2014-TCU-Plenário. Disponível em: 〈http://www.tcu.gov.br〉. Acesso em: 15. Ago 2015.

. Acórdão 1749/2014-TCU-Plenário. Disponível em: <http://www.tcu.gov.br>. Acesso em: 15. Ago 2015.

Acórdão 1888/2014-TCU-Plenário. Disponível em: 〈http://www.tcu.gov.br〉. Acesso em: 15. Ago 2015.

Acórdão 2354/2014-TCU-Plenário. Disponível em: 〈http://www.tcu.gov.br〉. Acesso em: 15. Ago 2015.

Acórdão 2453/2014-TCU-Plenário. Disponível em: 〈http://www.tcu.gov.br〉. Acesso em: 15. Ago 2015.

. Acórdão 2547/2014-TCU-Plenário. Disponível em: 〈http://www.tcu.gov.br〉. Acesso em: 15. Ago 2015.

. Acórdão 2690/2014-TCU-Plenário. Disponível em: 〈http://www.tcu.gov.br〉. Acesso em: 15. Ago 2015.

Acórdão 2693/2014-TCU-Plenário. Disponível em: 〈http://www.tcu.gov.br〉. Acesso em: 15. Ago 2015.

Acórdão 2981/2014-TCU-Plenário. Disponível em: 〈http://www.tcu.gov.br〉. Acesso em: 15. Ago 2015.

Acórdão 4312/2014-TCU-Primeira Câmara. Disponível em:

<http://www.tcu.gov.br>. Acesso em: 15. Ago 2015. 
Acórdão 15/2015-TCU-Plenário. Disponível em: 〈http://www.tcu.gov.br〉. Acesso em: 15. Ago 2015.

. Acórdão 163/2015-TCU-Plenário. Disponível em: 〈http://www.tcu.gov.br> . Acesso em: 15. Ago 2015.

Acórdão 253/2015-TCU-Plenário. Disponível em: 〈http://www.tcu.gov.br〉 . Acesso em: 15. Ago 2015.

. Acórdão 273/2015-TCU-Plenário. Disponível em: 〈http://www.tcu.gov.br〉. Acesso em: 15. Ago 2015.

. Acórdão 1743/2015-TCU-Primeira Câmara. Disponível em:

<http://www.tcu.gov.br>. Acesso em: 15. Ago 2015.

Acórdão 1850/2015-TCU-Plenário. Disponível em: 〈http://www.tcu.gov.br> . Acesso em: 15. Ago 2015.

Acórdão 2011/2015-TCU-Plenário. Disponível em: 〈http://www.tcu.gov.br> . Acesso em: 15. Ago 2015.

_ـ 5 motivos para a abertura de dados na Administração Pública. Brasília, 2015.

. Orientações para elaboração de planilhas orçamentárias de obras públicas.

Brasília: TCU, 2014.

. Obras Públicas Recomendações Básicas para a Contratação e Fiscalização de Obras de Edificações Públicas. $4^{\text {a }}$ Ed., Brasília: TCU, 2014.

. Relatórios de Fiscalização Sintéticos Fiscobras 2011. Disponível em:

<http://www.camara.gov.br/internet/comissao/index/mista/orca/orcamento/OR2012/fis cobras2011_sintetico/Index.html>. Acesso em: 15. Ago 2015.

. Relatórios de Fiscalização Sintéticos Fiscobras 2012. Disponível em:

<http://www.camara.gov.br/internet/comissao/index/mista/orca/orcamento/OR2013/Fis cobras2012/anexo2/index.html>. Acesso em: 15. Ago 2015.

. Relatórios de Fiscalização Sintéticos Fiscobras 2013. Disponível em: <http://www.camara.gov.br/internet/comissao/index/mista/orca/orcamento/OR2014/Fis cobras2013/anexo2/index.html>. Acesso em: 15. Ago 2015. 
Relatórios de Fiscalização Sintéticos Fiscobras 2014. Disponível em:

<http://www.camara.gov.br/internet/comissao/index/mista/orca/orcamento/OR2015/Fis cobras2014/anexo/index.html>. Acesso em: 15. Ago 2015.

TEIXEIRA, T.M.M. Apoio à Utilização dos Modelos de Contratação FIDIC.

Dissertação, Faculdade de Engenharia da Universidade do Porto. Porto, 2013.

U.S. GOVERNMENT ACCOUNTABILITY OFFICE. Report GAO-09-751 - July 2009. Disponível em: < http://www.gao.gov/assets/300/292935.pdf>. Acesso em: 15. Ago 2015.

U.S. DEPARTAMENT OF TRANSPORTATION. Federal Highway Administration. National Review of State Cost Estimation Practice - February 2015. Disponível em: < https://www.fhwa.dot.gov/construction/contracts/2014cost.pdf>. Acesso em: 15. Ago 2015.

Office of Inspector General. Audit Report MH-2013-012 - November 2012. Disponível em: < https://www.oig.dot.gov/library-item/28743>. Acesso em: 15. Ago 2015.

U.S. GENERAL SERVICES ADMINISTRATION. Federal Acquisition Regulation, FAR. Disponível em:

<https://www.acquisition.gov/sites/default/files/current/far/pdf/FAR.pdf $>$. Acesso em: 15. Ago 2015.

YU, W.; WANG, K.; WAND, M. (2013). Pricing Strategy for Best Value Tender.

Journal of Construction Engineering and Management, Volume 139, No. 6, June 2013, pp. 675-684

ZYMLER, B.; DIOS, L. C. Regime Diferenciado de Contratação - RDC. Belo Horizonte: Fórum, 2013. 


\section{GLOSSÁRIO}

A conceituação dos termos sobre gerenciamento de projetos e gerenciamento de riscos é apresentada tendo como referência o Guia PMBOK (2013).

Área de conhecimento em gerenciamento de projetos. Uma área identificada de gerenciamento de projetos definida por seus requisitos de conhecimentos e descrita em termos dos processos que a compõem, suas práticas, entradas, saídas, ferramentas e técnicas.

Gerenciamento da integração do projeto. O Gerenciamento da integração do projeto inclui os processos e as atividades necessárias para identificar, definir, combinar, unificar e coordenar os vários processos e atividades de gerenciamento do projeto dentro dos grupos de processos de gerenciamento do projeto.

Gerenciamento da qualidade do projeto. O Gerenciamento da qualidade do projeto inclui os processos e as atividades da organização executora que determinam as políticas de qualidade, os objetivos e as responsabilidades, de modo que o projeto satisfaça as necessidades para as quais foi empreendido.

Gerenciamento das aquisições do projeto. O gerenciamento das aquisições do projeto inclui os processos necessários para comprar ou adquirir produtos, serviços ou resultados externos à equipe do projeto.

Gerenciamento das comunicações do projeto. O gerenciamento das comunicações do projeto inclui os processos necessários para assegurar que as informações do projeto sejam planejadas, geradas, coletadas, distribuídas, armazenadas, recuperadas, gerenciadas, controladas, monitoradas e organizadas de maneira oportuna e apropriada.

Gerenciamento das partes interessadas do projeto. O Gerenciamento das partes interessadas do projeto inclui os processos exigidos para identificar todas as pessoas, grupos ou organizações que podem impactar ou serem impactados pelo projeto, analisar as expectativas das partes interessadas e seu impacto no projeto, e desenvolver estratégias de gerenciamento apropriadas para o engajamento eficaz das partes interessadas nas decisões e na execução do projeto. 
Gerenciamento de projetos. A aplicação de conhecimentos, habilidades, ferramentas e técnicas às atividades do projeto a fim de atender aos seus requisitos.

Gerenciamento do escopo do projeto. O Gerenciamento do escopo do projeto inclui os processos necessários para assegurar que o projeto inclua todo o trabalho necessário, e apenas o necessário, para que o projeto termine com êxito.

Gerenciamento do tempo do projeto. O Gerenciamento do tempo do projeto inclui os processos necessários para gerenciar o término pontual do projeto.

Gerenciamento dos custos do projeto. O gerenciamento dos custos do projeto inclui os processos envolvidos em planejamento, estimativas, orçamentos, financiamentos, gerenciamento e controle dos custos, de modo que o projeto possa ser terminado dentro do orçamento aprovado.

Gerenciamento dos recursos humanos do projeto. O gerenciamento dos recursos humanos do projeto inclui os processos que organizam, gerenciam e lideram a equipe do projeto.

Gerenciamento dos riscos do projeto. O gerenciamento dos riscos do projeto inclui os processos de planejamento, identificação, análise, planejamento de respostas, e controle de riscos de um projeto.

Grupo de processos de encerramento. Os processos executados para finalizar todas as atividades de todos os grupos de processos, visando encerrar formalmente o projeto ou a fase.

Grupo de processos de execução. Os processos realizados para executar o trabalho definido no plano de gerenciamento do projeto para satisfazer as especificações do mesmo.

Grupo de processos de gerenciamento de projetos. Um agrupamento lógico de entradas, ferramentas, técnicas e saídas de gerenciamento de projetos. Os grupos de processos de gerenciamento de projetos incluem processos de iniciação, processos de planejamento, processos de execução, processos de monitoramento e controle e processos de encerramento. Os grupos de processos de gerenciamento de projetos não são fases do projeto. 
Grupo de processos de iniciação. Os processos realizados para definir um novo projeto ou uma nova fase de um projeto existente, através da obtenção de autorização para iniciar o projeto ou fase.

Grupo de processos de monitoramento e controle. Os processos necessários para acompanhar, analisar e regular o progresso e o desempenho do projeto, identificar todas as áreas nas quais serão necessárias mudanças no plano e iniciar as mudanças correspondentes.

Grupo de processos de planejamento. Os processos necessários para definir o escopo do projeto, refinar os objetivos e desenvolver o curso de ação necessário para alcançar os objetivos para os quais o projeto foi criado.

Linha de base. A versão aprovada de um produto de trabalho que só pode ser alterada através de procedimentos formais de controle de mudança e é usada como uma base de comparação.

Linha de base da medição do desempenho. Um plano aprovado para o trabalho do projeto, integrando escopo, tempo e custos, em relação ao qual a execução do projeto é comparada e medida visando gerenciar o seu desempenho. A linha de base da medição do desempenho (PMB, do inglês Performance Measurement Baseline) inclui a reserva de contingência, mas exclui a reserva de gerenciamento.

Linha de base do cronograma. A versão aprovada de um modelo de cronograma que pode ser mudado somente mediante procedimentos de controle formais, e que é usado como uma base para a comparação com os resultados reais.

Linha de base do escopo. A versão aprovada de uma declaração de escopo e de uma estrutura analítica do projeto (EAP), e seu dicionário de EAP associado, que só pode ser mudada através de procedimentos de controle formais, e é usada como uma base de comparação.

Linha de base dos custos. Versão aprovada do orçamento referencial do projeto, excluindo quaisquer reservas de gerenciamento, que só pode ser mudada através de procedimentos formais de controle de mudanças e usada como base para comparação com os resultados reais. 
Processo. Uma série de atividades sistemáticas direcionadas para alcançar um resultado final de tal forma que se aja em relação a uma ou mais entradas a fim de criar uma ou mais saídas.

Projeto. Um esforço temporário empreendido para criar um produto, serviço ou resultado único.

Reserva. Uma provisão no plano de gerenciamento do projeto para mitigar os riscos de custos e/ou de cronograma. Muitas vezes usada com um modificador (por exemplo, reserva de gerenciamento, reserva de contingência) para fornecer mais detalhes sobre que tipos de risco devem ser mitigados.

Reserva de contingência. Orçamento contido na linha de base de custo ou na linha de base da medição de desempenho alocado para riscos identificados que são aceitos e para os quais respostas contingentes ou mitigadoras são desenvolvidas.

Reserva de gerenciamento. Uma porção do orçamento do projeto retida para fins de controle do gerenciamento. Estes são orçamentos reservados para o trabalho inesperado que está dentro do escopo do projeto. A reserva gerencial não está incluída na linha de base da medição de desempenho.

Risco. Um evento ou condição incerta que, se ocorrer, provocará um efeito positivo ou negativo em um ou mais objetivos do projeto.

Risco secundário. Um risco que surge como resultado direto da implementação de uma resposta aos riscos. 


\section{APÊNDICE I - ACÓRDÃO 2622/2013-TCU-PLENÁRIO}

Apresenta-se a conceituação sobre riscos, seguros e garantias constante no Acordão 2622/2013-TCU-Plenário.

\section{Riscos}

A literatura de diversas áreas de conhecimento geralmente define o conceito geral de riscos como eventos futuros e incertos, oriundos de fontes internas e externas, que podem influenciar de forma significativa o alcance dos objetivos de uma organização, cuja probabilidade de ocorrência e seus impactos não podem ser determinados com precisão antecipadamente. Em projetos de obras de engenharia, segundo Limmer (1996, p. 141), os riscos são uma constante ao longo de sua implementação e podem ser definidos como a perda potencial resultante de um incidente futuro resultante de ambientes interno e externo, que tendem a alterar o cenário inicialmente planejado.

Conforme bem salientado no relatório que antecede o Acórdão 2.369/2011-TCU-Plenário, 'em um orçamento de obra, por mais detalhado e criterioso que seja, é impossível prever com exatidão todas as peculiaridades do projeto'. Essa afirmação decorre da constatação de que sempre existirá um certo grau de incerteza na implantação de qualquer empreendimento, cujos diversos tipos de riscos podem afetar de forma positiva ou negativa os objetivos do projeto, tais como: prazo de execução, qualidade dos serviços executados, custos totais, escopo do objeto, dentre outros.

O conceito de riscos relacionados à implantação de projeto de engenharia também está relacionado com o conceito de contingências geralmente adotado em empreendimentos industriais. Segundo a AACEI, contingências representam custos previsíveis que possuem razoável probabilidade de virem a ser efetuadas, mas que não são quantificáveis à época da estimativa, sendo um adicional à estimativa de custos que cobre, entre outros, erros e omissões de planejamento e estimativa, flutuações pequenas de preços (não se caracterizando o efeito de escalonamento de preços), a evolução do design, mudanças no âmbito do escopo e variações de mercado e condições ambientais.

No presente estudo, considera-se que riscos e contingências a serem considerados nos orçamentos de obras públicas possuem significados semelhantes. Em obras em geral, não especificamente empreendimentos industriais, caso tratado pela AACEI, a prática 
generalizada no país é a inclusão uma taxa de riscos ou contingências como um percentual fixo na composição de BDI. No entanto, o cálculo dessa taxa envolve, essencialmente, um processo de análise de riscos a partir da elaboração de uma matriz de riscos que tem por objetivo estabelecer as diretrizes que nortearam as cláusulas contratuais de obras públicas e esclarecer os possíveis efeitos decorrentes de eventos futuros e incertos que podem ser assumidos ou repartidos entre as partes contratantes.

Por meio de uma matriz de riscos é possível, por exemplo, identificar os principais elementos que podem influenciar a implantação de um empreendimento, estabelecer as estratégias de mitigação ou alocação dos riscos identificados e avaliar a probabilidade de ocorrência dos eventos e seus respectivos impactos financeiros. A título de ilustração, citase a matriz de riscos da licitação de concessão do Aeroporto Internacional de São Gonçalo do Amarante, disponível no sítio eletrônico da Agência Nacional de Aviação Civil (ANAC).

\section{Identificação, mitigação e alocação de riscos}

Em contratações de obras públicas, a matriz de riscos deve, primeiramente, separar os diversos tipos de riscos associados ao empreendimento cujos impactos devem ser mensurados na taxa de riscos do BDI ou ensejar a repactuação de preços por meio de aditivos contratuais. De uma forma geral, embora não haja uma padronização das terminologias empregadas no meio técnico da construção civil, os diversos tipos de riscos nas contratações de obras públicas podem ser consolidados em cinco categorias: riscos de engenharia (ou riscos de execução); riscos normais ou comuns de projetos de engenharia; riscos de erros de projeto de engenharia; riscos de fatos da Administração; e riscos associados à álea extraordinária/extracontratual (fato do príncipe, força maior ou caso fortuito).

\section{a) riscos de engenharia (ou riscos de construção):}

Os riscos de engenharia (ou riscos de construção) são aqueles associados diretamente às atividades empresariais propriamente ditas de construção civil, comuns à execução de qualquer empreendimento e suportados pelo contratado. São riscos usuais de negócio de um construtor que podem impactar a execução, o gerenciamento, a produtividade e a performance da obra, com consequências significativas sobre os seus custos globais. A 
título de exemplificação, Carvalho e Pini (2012, p. 28/30) classificam esses riscos em contingências de execução, canteiro e produção, conforme trechos reproduzidos a seguir:

As Contingências de Execução dizem respeito a eventuais problemas, frente à adequação do treinamento da mão de obra, na aplicabilidade e consumo dos materiais ou ao desempenho da produção dos equipamentos ou ainda frente às dificuldades no desenvolvimento do projeto do processo executivo.

As Contingências de Canteiro englobam as quedas de produtividade da mão de obra e na produção dos equipamentos, ocorridas por condições críticas de operação, advindas de disfunções logísticas, períodos descontínuos de trabalho, influência de tráfego de pessoas ou veículos (empreendimentos, internos à malha urbana), obras executadas com edifícios em uso, falhas de manutenção e operação.

As Contingências de Produção estão relacionadas à aplicabilidade do Plano de ataque concebido para elaborar a obra como um todo, onde problemas de gestão afetam diretamente o desempenho na produtividade da mão de obra, no consumo de materiais e produtos ou na produção de equipamentos.

Uma medida que pode ser eficaz para reduzir ou minimizar os efeitos financeiros da ocorrência de eventos desfavoráveis (ameaças) a que o construtor está exposto é a previsão de contratação de seguros da obra para cobrir grande parte desses eventos futuros e incertos, como: riscos de engenharia, responsabilidade civil etc. Embora os prêmios de seguros onerem os preços de contratação da obra, por outro lado, a cobertura desses riscos permite reduzir a taxa de riscos considerada na composição de BDI, cuja análise custobenefício (prêmios de seguro vs. taxa de riscos) deve ser feita caso a caso, conforme será abordado no tópico que trata especificamente de seguros em obras públicas.

\section{b) riscos normais de projetos de engenharia:}

Os riscos normais (ou comuns) associados ao projeto de engenharia são aqueles que ainda permanecem após a conclusão de um projeto bem elaborado e suficiente para caracterizar o objeto, em atendimento aos requisitos e elementos exigidos na legislação de licitações e contratos, mas que, em função de suas próprias características intrínsecas, ainda são submetidos a um certo grau de incerteza naturalmente existente em qualquer projeto, o que pode acarretar, por exemplo, acréscimos ou decréscimos de quantitativos de serviços inicialmente planejados. 
Esse tipo de riscos não tem relação com os erros de projetos de engenharia por falha ou imperícia da Administração Pública nem inclui as alterações de escopo procedidas pela contratante para melhor adequação técnica aos seus objetivos, nos termos do art. 65, inciso I, alínea a, da Lei 8.666/1993. As alterações de escopo referem-se à mudança de objeto durante a fase de execução do contrato, por meio de acréscimos ou decréscimos de serviços, atividades ou etapas não previstos inicialmente no projeto de engenharia, mas que se tornaram necessários ou úteis para a consecução do objeto contratual, sendo objeto de aditamentos contratuais.

Destaca-se que os riscos normais de projetos podem ser reduzidos por meio da elaboração de projetos de engenharia com maior nível de detalhamento. Em regra, espera-se que as estimativas e orçamentos elaborados com base em anteprojeto sejam mais imprecisos que os orçamentos elaborados a partir de projetos básicos ou executivos, de forma que o parâmetro relacionado a riscos e contingências a ser utilizado na composição de BDI seja mais elevado.

Outra estratégia é a alocação de riscos entre as partes contratantes por meio da escolha do regime de execução dos contratos de obras públicas. No regime de empreitada por preços unitários, a Administração assume os riscos das variações de quantitativos, enquanto que nas empreitadas por preço global e integral, ao contrário, esses riscos são concentrados na figura da empresa contratada. De uma forma geral, considera-se que os percentuais de riscos na composição de BDI de obras públicas tendem a ser menores para o regime de preços unitários em relação aos demais regimes de execução previstos na Lei 8.666/1993, visto que há uma maior concentração de riscos na Administração Pública.

Há ainda as licitações de obras realizadas no âmbito do Regime Diferenciado de Contratações (RDC). No caso da contratação integrada, mediante a contratação simultânea de projetos e execução da obra, a licitação com base em anteprojeto, com menor grau de grau de detalhamento em relação ao projeto básico, em princípio, justificaria uma taxa de risco ainda maior quanto aos possíveis eventos que podem afetar os custos da obra durante a sua fase de execução.

\section{c) riscos de erros de projetos de engenharia}

Os riscos de erros de projetos de engenharia são aqueles relacionados a eventos que podem decorrer, por exemplo, de falhas de orçamentos por omissão de serviços ou quantitativos 
insuficientes, especificações técnicas incompletas, imprecisão do cronograma de execução da obra, não previsão de interferências construtivas (redes elétricas, dutos subterrâneos etc.), dentre outras falhas decorrentes da elaboração de projetos de engenharia deficientes.

Esses riscos também incluem as denominadas 'situações ou ocorrências imprevistas', comumente observadas em obras rodoviárias, ferroviárias ou construção de barragens, quando durante a sua execução, o contratado depara-se com falhas geológicas, lençóis freáticos ou cursos d'água subterrâneos, que poderiam ser detectados por meio de sondagens realizadas ainda na fase de elaboração do projeto de engenharia, anteriormente à celebração do respectivo contrato administrativo.

Cumpre salientar que a diferença entre os riscos de erros de projetos (projeto deficiente) e os riscos normais de projetos (existentes naturalmente em qualquer projeto) nem sempre é de fácil identificação. Mesmo em projetos bem elaborados existem serviços de engenharia que contêm certo grau de incerteza intrínseca de seus quantitativos de serviços. É o caso dos serviços de terraplanagem de rodovias, ferrovias e barragens em relação aos fatores de contração e outros cálculos aproximados do volume de movimentação de terra. Essas incertezas nos quantitativos de tais serviços não pressupõem, por si só, uma deficiência do projeto de engenharia.

Por serem suportados pela Administração Pública, entende-se que os riscos de erros de projetos de engenharia não devem ser considerados no cálculo da taxa de risco do BDI de obras públicas, visto que a ocorrência desses erros pode ser objeto de repactuação de preços por meio de aditivos contratuais visando à recomposição do equilíbrio econômico financeiro dos contratos administrativos, com fundamento nos arts. 57, $\S 1^{\circ}$, incisos I e IV, 58, inciso I, e 65, inciso I, alínea b, da Lei 8.666/1993.

\section{d) riscos associados a fatos da Administração}

Os riscos associados aos fatos da Administração são aquelas possíveis ocorrências que decorrem de providências adotadas ou de omissões não imputáveis ao particular, que podem favorecer ou retardar/impedir a execução adequada da obra. Esses riscos podem ser subdivididos em diversos tipos, como: (i) riscos de não liberação do local da obra; (ii) riscos de não entrega de instalações existentes; (iii) riscos de atrasos de pagamentos; (iv) riscos de atrasos de desapropriações de imóveis e/ou servidão de passagem; (v) risco de demora ou não obtenção de licenças ambientais; (vi) riscos de encontrar sítios 
arqueológicos etc. Entende-se também que esses riscos não devem ser considerados no cálculo da taxa de risco do BDI de obras públicas por serem passíveis de repactuação de preços por meio de aditivos contratuais, nos termos do art. $57, \S 1^{\circ}$, incisos III e VI, da Lei 8.666/1993.

\section{e) riscos associados à álea extraordinária/extracontratual:}

Os riscos associados à álea extraordinária ou extracontratual (fato do príncipe, força maior ou caso fortuito) referem-se a eventos imprevisíveis, ou previsíveis, porém de consequências incalculáveis. São eventos alheios à vontade das partes contratantes ou estranhos à atividade de implantação do empreendimento. São exemplos: terremoto, inundação imprevisível ou qualquer outro fenômeno natural extraordinário que impossibilite ou retarde a execução do contrato, choque externo de mercado com a elevação extraordinária dos preços, alterações da carga tributária incidente sobre o faturamento, revolta popular incontrolável etc.

A ocorrência desses eventos também provoca um desequilíbrio da equação econômicofinanceira ou dificulta a execução do contrato nas condições originalmente estipuladas, o que permite a repactuação dos preços por meio de aditivos contratuais, nos termos do art. 57, $\S 1^{\circ}$, inciso II, e art. 65, inciso II, alínea d, da Lei 8.666/1993. Em função disso, considera-se também que esses riscos não devem ser considerados no cálculo da taxa de risco do BDI de obras públicas.

A partir da análise realizada acima, conclui-se que tipos de riscos que devem constar da composição de BDI de obras públicas são somente aqueles que se referem a eventos que não ensejam a repactuação das cláusulas financeiras dos contratos administrativos, em conformidade com as disposições legais contidas na Lei 8.666/1993 e legislações correlatas. Desse modo, o cálculo da estimativa da taxa de riscos do BDI somente inclui os riscos de engenharia (ou riscos de construção), que são inerentes às atividades empresariais de implantação de empreendimentos, e, a depender do regime de execução, os riscos normais de projetos de engenharia, quando não decorrentes de erros ocasionados pela parte da Administração Pública.

Conforme já salientado, os impactos dessas duas categorias de riscos podem ser mitigados ou repartidos de acordo com o grau de detalhamento do projeto de engenharia, do regime de execução adotado e/ou da exigência de contratação de seguros, conforme estratégia de 
alocação de riscos adotada ainda fase de planejamento da obra com a elaboração da matriz de riscos. Conquanto possam ser mitigados ou repartidos, deve-se ressaltar que os riscos associados à execução de obras públicas dificilmente serão nulos, visto que sempre há alguma parcela de riscos não coberta pelas medidas adotadas pela Administração.

Por fim, importa registrar que o nível de riscos está associado ao nível de lucratividade de um empreendimento, já que, quando da não materialização de eventos futuros e incertos, o percentual de riscos estimado na composição de BDI de obras públicas para fazer face aos seus impactos financeiros passa a ser incorporado à remuneração do construtor, não podendo ser glosado, conforme bem destacou o relatório do Acórdão 2.369/2011-TCUPlenário, in verbis:

Assim sendo, por serem despesas que não participam da formação dos custos unitários, nada mais adequado do que contemplar, no BDI, uma parcela para reposição dos custos com seguros e garantias e com riscos. Não se trata de custear situações previsíveis que deverão estar contempladas no custo direto, nem tão pouco de ressarcir despesas com eventos aleatórios que podem ser ressarcidos por meio de mecanismos legais. Busca-se, sim, recompor os custos com os riscos e as incertezas propriamente ditos, que, caso não ocorram, serão incorporadas ao lucro, e não poderão ser glosadas. (grifos nossos)

\section{Mensuração dos riscos}

A etapa de mensuração dos riscos envolve ainda a análise da probabilidade de ocorrência e do cálculo dos possíveis impactos dos eventos identificados que são capazes de influenciar os custos totais de implantação de um projeto de obra de engenharia, com vistas a determinar a dimensão de cada risco e a definir a melhor forma de gerenciar tais riscos. Essa etapa da análise de riscos requer, essencialmente, o conhecimento, experiência e habilidade do estimador, bem como a existência de bancos dados e a disponibilidade de outras informações sobre projetos anteriores semelhantes.

Os métodos geralmente empregados para a mensuração dos riscos podem contemplar tanto análises qualitativas como também análises quantitativas. Segundo a AACEI (IRP 40R08), os seguintes métodos podem ser empregados para o cálculo das contingências: (i)

julgamento do especialista (experiência do estimador); (ii) diretrizes pré-determinadas (associada a empirismo de projetos anteriores e experiência do estimador); (iii) análise de 
simulação de riscos, podendo ser adotada a metodologia da faixa de estimativa, valor esperado ou modelagem paramétrica; e (iv) métodos híbridos (combinação dos anteriores).

Em orçamentos de obras públicas, a mensuração dos riscos deve se basear em uma técnica consistente, que assegure que o risco seja quantificado de maneira sistemática, transparente e confiável, de forma a permitir a cobertura de custos adicionais decorrentes de eventos cujos efeitos sejam incertos. Diante da impossibilidade de empregar técnicas mais complexas para o cálculo da parcela de riscos para cada obra em particular, entende-se que os referenciais extraídos de fontes baseadas em análise estatísticas de projetos semelhantes podem ser paradigmas confiáveis para a determinação do percentual a ser adotado na taxa de BDI.

Em face do exposto, conclui-se que o cálculo da taxa de riscos do BDI de obras públicas está relacionado à identificação e mensuração dos riscos de engenharia e, a depender do regime de execução do contrato, dos riscos normais de projeto de engenharia, não decorrentes de erros por parte da Administração Pública. Esses riscos podem ser mitigados com a elaboração de projeto com alto grau de detalhamento ou repartidos de acordo com o regime de execução contratual e/ou da exigência de contratação de seguros. A materialização de outros eventos ou circunstâncias que onerem os encargos assumidos pelo particular pode ser objeto de aditivos contratuais, com o objetivo de garantir a manutenção do equilíbrio econômico-financeiro da avença.

\section{Seguros}

Seguros são contratos regidos pelo direito privado firmados entre o particular (segurado) e a companhia seguradora (segurador), por meio dos quais o segurador se obriga, mediante o recebimento antecipado de um prêmio, a reparar danos causados ao particular segurado ou a terceiros pela ocorrência de eventos alheios a sua vontade devidamente especificados na apólice de seguro, limitando-se essa obrigação ao valor da importância segurada a que tem direito o segurado pela ocorrência do sinistro.

Em contratações de obras públicas, a exigência de contratação de seguros tem por objetivo a transferência principalmente dos riscos inerentes às atividades empresariais de construção civil (riscos de engenharia ou de construção) para as companhias seguradoras, como: erros de execução, incêndio e explosão, danos da natureza (vendaval, destelhamento, alagamento, inundação, desmoronamento, geadas etc.), emprego de 
material defeituoso ou inadequado, roubo e/ou furto qualificado, quebra de equipamentos, desmoronamento de estrutura, dentre outros.

O Seguro de Riscos de Engenharia, por exemplo, atualmente disciplinado pela Circular Susep 419, de 17 de janeiro de 2011, da Superintendência de Seguros Privados, é um tipo de seguro amplamente empregado em grandes projetos de infraestrutura especificamente destinado à transferência de riscos de contratos de empreitada de obras. De acordo com Escola Nacional de Seguros, essa espécie de seguro é denominada internacionalmente de All Risks, ou seja, todo e qualquer evento está coberto na apólice de seguro, à exceção daqueles que são citados expressamente como excluídos. Sendo assim, todos os eventos não listados como excluídos têm cobertura do seguro de riscos de engenharia (http://www.tudosobreseguros.org.br/sws/portal/pagina.php?1=505\#all_risks).

De acordo com a Circular Susep 419/2011, para empreendimentos em fase de construção, a contratação desse seguro pode compreender as seguintes modalidades de coberturas básicas: (i) Obras Civis em Construção (OCC); Instalação e Montagem (IM); e Obras Civis em Construção e Instalação e Montagem (OCC/IM). Também podem ser contratadas coberturas adicionais para ampliação dessas coberturas básicas, como: cobertura de responsabilidade civil geral, cobertura de responsabilidade civil cruzada, cobertura de despesas extraordinárias, cobertura de tumultos, cobertura de desentulho do local, cobertura de riscos do fabricante, dentre outras.

As coberturas desse tipo de seguro iniciam-se imediatamente após a descarga dos materiais ou equipamentos do segurado no canteiro de obras e termina com a aceitação, ou colocação em funcionamento do empreendimento. No caso de atraso no cronograma de execução e/ou alterações do valor do objeto segurado, a apólice de seguro deve ser alterada por meio de endosso, que também é chamado de aditivo ou suplemento, que tem por finalidade consignar quaisquer alterações ocorridas após a emissão da apólice (arts. $3^{\circ}$ e 12 do Anexo da Circular Susep 419/2011).

Nos orçamentos de obras públicas, considera-se que a parcela de seguros da composição de BDI refere-se ao valor monetário do prêmio de seguro pago pelo particular segurado à companhia seguradora em contrapartida à cobertura dos riscos contratados, cujos encargos financeiros assumidos pelo particular são repassados aos preços das obras a serem contratadas pela Administração Pública. O cálculo do prêmio de seguro pode variar de acordo com o perfil dos segurados e as características do objeto segurado, como: custos 
totais de implantação, complexidade e porte da obra, cronograma de execução, condições locais, métodos construtivos, dentre outras variáveis.

No mais, a decisão acerca da exigência de contratação de um ou mais modalidades de seguros para a execução de obras públicas envolve, em cada caso concreto, uma análise custo-benefício da relação existente entre o acréscimo de custos da obra com o repasse dos encargos financeiros do prêmio de seguro e os benefícios dessa contratação com a redução da taxa de riscos a ser mensurada na composição de BDI.

Entretanto, mesmo com a exigência de contratação de seguros, deve-se considerar que sempre existe um risco residual a que o particular ainda continua descoberto, que deve ser tratado e mensurado na taxa de riscos do BDI. Cabe registrar que não foi objeto do presente estudo a realização de simulações do cálculo da relação entre riscos e seguros, que poderá ser objeto de maior aprofundamento em outros estudos específicos sobre esse tema.

Portanto, conquanto não elimine todos os riscos associados à execução do objeto contratual, conclui-se que a contratação de seguros é uma das medidas adotadas pelo gestor público como estratégia de alocação dos riscos inerentes às atividades de execução da obra, cujo cálculo dos encargos financeiros do prêmio de seguros a serem repassados aos preços das obras públicas deve ser avaliado em conjunto com a mensuração dos riscos residuais a serem incluídos na composição de BDI, por meio de uma análise custo-benefício para cada caso concreto.

\section{Garantias}

A garantia contratual tem por objetivo resguardar a Administração Pública contra possíveis prejuízos causados pelo particular contratado em razão de inadimplemento das disposições contratuais, sendo exigida por decisão discricionária do administrador público, desde que prevista no instrumento convocatório, nos termos do art. 56 da Lei 8.666/1993.

A garantia prestada pelo particular não excederá a $5 \%$ do valor do contrato administrativo e terá seu valor atualizado nas mesmas condições daquele. Para obras, serviços e fornecimentos de grande vulto com alta complexidade técnica e riscos financeiros consideráveis, demonstrados por meio de parecer tecnicamente aprovado pela autoridade competente, o limite da garantia poderá ser elevado até $10 \%$ do valor contratado, conforme art. $56, \S \S 2^{\circ}$ e $3^{\circ}$, da Lei 8.666/1993. 
Cabe observar que é o contratado quem escolhe uma das quatro modalidades de garantia previstas em lei (art. 56, § $1^{\circ}$, da Lei 8.666/1993), a saber: caução em dinheiro, caução em títulos da dívida pública, fiança bancária ou seguro-garantia. Nos casos das duas primeiras modalidades, o contratado transfere para a Administração Pública a posse da quantia monetária em dinheiro ou dos títulos públicos até o pleno cumprimento dos encargos contratuais, sendo restituídos após a execução do contrato e atualizados monetariamente, no caso de caução em dinheiro. Nesses casos, quando não há impactos financeiros para o contratado, entende-se que não seria possível a previsão de qualquer percentual da parcela de garantia contratual no BDI de obras públicas.

Quanto à fiança bancária, a instituição financeira se responsabiliza a pagar à Administração um determinado valor até o limite afiançado na hipótese de inadimplemento do contratado. No caso do seguro-garantia, a lei define essa modalidade de garantia como 'o seguro que garante o fiel cumprimento das obrigações assumidas por empresas em licitações e contratos', sendo regulamento atualmente pela Circular SUSEP 232, de 3 de junho de 2003.

Nesse negócio jurídico, também conhecido como Perfomance Bond, o particular contratado (tomador), mediante pagamento de um prêmio, contrata o seguro-garantia em favor da contratante (segurado - p. ex.: Administração Pública), por meio do qual a seguradora se obriga a garantir, até o limite do valor segurado na apólice, o cumprimento das obrigações cobertas pelo seguro ou o pagamento de indenização dos prejuízos diretos resultantes do inadimplemento das obrigações assumidas pelo tomador no contrato principal (p. ex.: contrato de obras públicas).

De acordo com o item 7.1 do Anexo I da Circular Susep 232/2003, caracterizado o sinistro, que é o inadimplemento das obrigações cobertas pelo seguro-garantia por parte do tomador, a seguradora deve indenizar o segurado até o limite da garantia prevista na apólice de seguro: (i) realizando, por meio de terceiros, o objeto do contrato principal, de forma a lhe dar continuidade e o concluir, sob a sua integral responsabilidade; ou pagando os prejuízos causados pela inadimplência do tomador das obrigações contratuais.

No entanto, segundo Maia (2011, p. 2), nos contratos administrativos, a indenização das companhias seguradoras limita-se ao pagamento dos prejuízos sofridos pela Administração Pública em razão do descumprimento das obrigações assumidas pelo tomador em relação ao contrato principal: 
(...) quando oferecida como garantia de obrigações assumidas pelo tomador em contrato administrativo (art. 56, $\S 1^{\circ}$, II, da Lei $\mathrm{n}^{\circ}$ 8.666/1993), a Perfomance Bond acaba se limitando, na prática, à garantia de indenização por perdas e danos gerados pelo inadimplemento contratual, tendo em vista que, por força do art. $56, \S 2^{\circ}$ da referida Lei - o qual visa assegurar a isonomia entre os concorrentes -, o capital segurado não pode exceder a cinco por cento do valor do contrato principal (podendo chegar a dez por cento, nas hipóteses do art. 56, $\S 3^{\circ}$ da Lei ${ }^{\circ}$ 8.666/1993).

Confirma essa assertiva o fato de que o art. 80, III, da Lei $n^{\circ} 8.666 / 1993$, prevê que a rescisão do contrato por ato unilateral e escrito da Administração, nas hipóteses de descumprimento contratual injustificado (casos enumerado nos incisos I a XII e XVII, do art. 78), acarreta, dentre outras consequências, 'a execução da garantia contratual, para ressarcimento da Administração, e dos valores das multas e indenizações a ela devidos.' (grifos no original)

Atualmente, o seguro-garantia tem sido considerado a modalidade mais acessível e econômica para o contratado, sendo amplamente utilizada em grandes de projetos de infraestrutura. Segundo Justen Fiho (2010, p. 720), o seguro-garantia 'passou a ter grande relevo, na medida em que o custo passou a ser menor do que o das demais modalidades previstas no elenco do art. 56. Como decorrência, difundiu-se a opção dos interessados pelo seguro-garantia.' Essa modalidade de garantia recentemente ganhou um novo incentivo com a redução da alíquota do Imposto sobre Operações de Crédito, Câmbio e Seguros (IOF), de 7,38\% para 0\%, mediante a publicação do Decreto 7.787, de 15 de agosto de 2012.

De acordo com o relatório que antecede o Acórdão 325/2007-TCU-Plenário, o percentual atribuível ao seguro-garantia no BDI depende do prazo de execução da obra, da classificação de risco da empresa e da negociação do prêmio com a seguradora, sendo que 'Referências de instituições operadoras de seguros indicam que o prêmio pela garantia situa-se no intervalo percentual de $0,45 \%$ a $4,0 \%$ ao ano sobre o valor da apólice, conforme a classificação obtida pela empresa junto à instituição seguradora. Isso corresponde a uma variação de $0,0225 \%$ a $0,2 \%$ sobre o valor do contrato, para as garantias equivalentes a $5 \%$ desse valor e, uma variação de $0,045 \%$ a $0,4 \%$, quanto a garantia atingir $10 \%$ do valor contratado' 
Sob o ponto de vista dos orçamentos de obras públicas, considera-se que a exigência de prestação de garantia contratual é uma estratégia de alocação de riscos como medida que visa a assegurar o adequado adimplemento do contrato e a facilitar o ressarcimento de possíveis prejuízos sofridos pela Administração Pública, na hipótese de inexecução por parte do particular contratado. Em função disso, a sua exigência deve ser avaliada caso a caso, levando em conta a complexidade e as especificidades do objeto a ser segurado, dentre outras variáveis, visto que, no caso de o particular optar pelo oferecimento de fiança bancária ou seguro-garantia, os custos de sua contratação acarretam um ônus econômico a ser repassado aos preços das obras na composição de BDI.

Esses custos podem ser aumentados durante a execução das obras, em virtude da obrigação do contratado providenciar a alteração da garantia prestada quando efetuadas alterações no prazo de vigência e nos valores originalmente previstos no contrato administrativo, já que o período de cobertura e o valor da garantia devem acompanhar tais modificações, nos termos do art. 56, $\S 2^{\circ}$, da Lei 8.666/1993. Por fim, a garantia prestada somente é liberada ou restituída após a execução do objeto contratado e o pleno cumprimento de todas as obrigações contratuais, mediante recebimento definitivo da obra, conforme entendimento firmado no Acórdão 2.244/2010-TCU-Plenário.

Conclui-se, dessa forma, que os custos da prestação de garantia para o pleno cumprimento das obrigações contratuais assumidas pelo particular contratado, caso expressamente prevista no instrumento convocatório, são repassados aos preços das obras públicas e inseridos na composição de BDI de obras públicas, devendo, no entanto, a Administração exigir a alteração da garantia prestada, a cada celebração de termo aditivo, quando efetuadas alterações no prazo de vigência e nos valores previamente estabelecidos no contrato administrativo das obras.

A respeito da taxa de riscos, o seu cálculo para o BDI de obras públicas contempla somente os riscos inerentes às atividades de construção e, a depender do regime de execução, os imprevistos normais e comuns existentes em qualquer projeto de engenharia elaborado pela Administração Pública em conformidade com a lei. Tais contingências podem ser mitigadas ou repartidas a partir de acordo com o regime de execução contratual utilizado ou com a elaboração de projeto de engenharia com alto grau de detalhamento, a exemplo do projeto executivo, bem como pela contratação de seguros. 
Os riscos associados a eventos que justificam a celebração de aditivos contratuais não devem ser mensurados na taxa de BDI, a exemplo de possíveis falhas de projetos de engenharia por imprecisão ou imperícia da Administração Pública; da ação ou omissão do cumprimento das cláusulas do contrato por culpa da Administração; e as situações extraordinárias e extracontratuais estranhas à vontade das partes contratantes. São eventos que alteram o equilíbrio econômico-financeiro e que, portanto, a legislação autoriza a revisão das cláusulas financeiras dos contratos administrativos. 


\section{APÊNDICE II - CLASSIFICAÇÃO DE ESTIMATIVAS DE CUSTO}

$\mathrm{O}$ anexo II apresenta as matrizes de classificação de estimativas de custos das práticas recomendadas RP 17R-97(2011), RP 18R-97(2011) e a RP 56R-08(2012) e os gráficos que mostram as faixas (intervalos) de precisão para os empreendimentos da indústria de processo e da indústria da construção em geral.

\section{RP 17R-97(2011)}

\begin{tabular}{|c|c|c|c|c|c|}
\hline & $\begin{array}{c}\text { Característica } \\
\text { Primária }\end{array}$ & \multicolumn{4}{|c|}{ Característica Secundária } \\
\hline $\begin{array}{l}\text { CLASSE DE } \\
\text { ESTIMATIVA }\end{array}$ & $\begin{array}{c}\text { NÍVEL DE } \\
\text { MATURIDADE DAS } \\
\text { ENTREGAS DENIFIDAS } \\
\text { NO PROJETO Expresso } \\
\text { como \% da definição } \\
\text { completa }\end{array}$ & $\begin{array}{l}\text { USO FINAL } \\
\text { Finalidade típica de } \\
\text { estimativa }\end{array}$ & $\begin{array}{c}\text { METODOLOGIA } \\
\text { Método de estimativa } \\
\text { típica }\end{array}$ & $\begin{array}{l}\text { INTERVALO DE } \\
\text { PRECISÃO } \\
\text { ESPERADO } \\
\text { Típico intervalo (+/-) } \\
\text { em relação ao índice } \\
\text { de } 1 \text { (ou seja, } \\
\text { estimativa Classe 1) [a] }\end{array}$ & $\begin{array}{c}\text { ESFORÇO DE } \\
\text { PREPARAÇÃO } \\
\text { Típico grau de esforço } \\
\text { em relação ao índice } \\
\text { de custo mínimo de } 1 \\
{\left[\begin{array}{l}{[b]} \\
\text { a }\end{array}\right.}\end{array}$ \\
\hline Classe 5 & $0 \%$ a $2 \%$ & $\begin{array}{l}\text { Viabilidade (ou } \\
\text { Screening) }\end{array}$ & $\begin{array}{l}\text { Estocástico } \\
\text { (fatores e/ou } \\
\text { modelos) ou } \\
\text { julgamento }\end{array}$ & 4 a 20 & 1 \\
\hline Classe 4 & $1 \%$ a $15 \%$ & $\begin{array}{l}\text { Estudo de } \\
\text { conceito ou de } \\
\text { viabilidade }\end{array}$ & $\begin{array}{l}\text { Principalmente } \\
\text { estocástico }\end{array}$ & 3 a 12 & 2 a 4 \\
\hline Classe 3 & $10 \%$ a $40 \%$ & $\begin{array}{c}\text { Orçamento, } \\
\text { autorização ou } \\
\text { controle }\end{array}$ & $\begin{array}{l}\text { Mistas mais } \\
\text { principalmente } \\
\text { estocásticas }\end{array}$ & 2 a 6 & 3 a 10 \\
\hline Classe 2 & $30 \%$ a $75 \%$ & $\begin{array}{c}\text { Controle ou } \\
\text { licitação/concurso }\end{array}$ & $\begin{array}{l}\text { Principalmente } \\
\text { determinístico }\end{array}$ & 1 a 3 & 5 a 20 \\
\hline Classe 1 & $65 \%$ a $100 \%$ & $\begin{array}{l}\text { Estimativa de } \\
\text { verificação ou } \\
\text { licitação/concurso }\end{array}$ & Determinístico & 1 & 10 a 100 \\
\hline
\end{tabular}

RP 18R-97(2011) 


\begin{tabular}{|c|c|c|c|c|}
\hline & $\begin{array}{l}\text { Característica } \\
\text { Primária }\end{array}$ & \multicolumn{3}{|c|}{ Característica Secundária } \\
\hline $\begin{array}{l}\text { CLASSE DE } \\
\text { ESTIMATIVA }\end{array}$ & $\begin{array}{l}\text { NÍVEL DE MATURIDADE } \\
\text { DAS ENTREGAS } \\
\text { DENIFIDAS NO PROJETO } \\
\text { Expresso como \% da definição } \\
\text { completa }\end{array}$ & $\begin{array}{l}\text { USO FINAL } \\
\text { Finalidade típica de } \\
\text { estimativa }\end{array}$ & $\begin{array}{l}\text { METODOLOGIA } \\
\text { Método de estimativa típica }\end{array}$ & $\begin{array}{c}\text { INTERVALO DE } \\
\text { PRECISÃO ESPERADO } \\
\text { Variação típica em faixas de } \\
\text { baixa e alta [a] }\end{array}$ \\
\hline Classe 5 & $0 \%$ a $2 \%$ & $\begin{array}{l}\text { Viabilidade (ou } \\
\text { Screening) }\end{array}$ & $\begin{array}{l}\text { Fatores de capacidade, } \\
\text { modelos paramétricos, } \\
\text { julgamento ou analogia }\end{array}$ & $\begin{array}{l}\text { L: }-20 \% \text { a }-50 \% \\
H:+30 \% \text { a }+100 \%\end{array}$ \\
\hline Classe 4 & $1 \%$ а $15 \%$ & $\begin{array}{l}\text { Estudo de } \\
\text { viabilidade }\end{array}$ & $\begin{array}{l}\text { Equipamento consignado } \\
\text { ou modelos paramétricos }\end{array}$ & $\begin{array}{l}\text { L: }-15 \% \text { a }-30 \% \\
H:+20 \% a+50 \%\end{array}$ \\
\hline Classe 3 & $10 \%$ a $40 \%$ & $\begin{array}{l}\text { Autorização } \\
\text { orçamentária ou } \\
\text { controle }\end{array}$ & $\begin{array}{l}\text { Custos unitários semi- } \\
\text { detalhados c/ itens em } \\
\text { nível de linha de } \\
\text { montagem }\end{array}$ & $\begin{array}{l}\text { L: }-10 \% \text { a }-20 \% \\
H:+10 \% \text { a }+30 \%\end{array}$ \\
\hline Classe 2 & $30 \%$ a $75 \%$ & $\begin{array}{c}\text { Controle ou } \\
\text { licitação/concurso }\end{array}$ & Custo unitário detalhado & $\begin{array}{l}L:-5 \% \text { a }-15 \% \\
H:+5 \% \text { a }+20 \%\end{array}$ \\
\hline Classe 1 & $65 \%$ a $100 \%$ & $\begin{array}{c}\text { Estimativa de } \\
\text { verificação ou } \\
\text { licitação/concurso }\end{array}$ & Custo unitário detalhado & $\begin{array}{l}L:-3 \% \text { a }-10 \% \\
H:+3 \% \text { a }+15 \%\end{array}$ \\
\hline
\end{tabular}




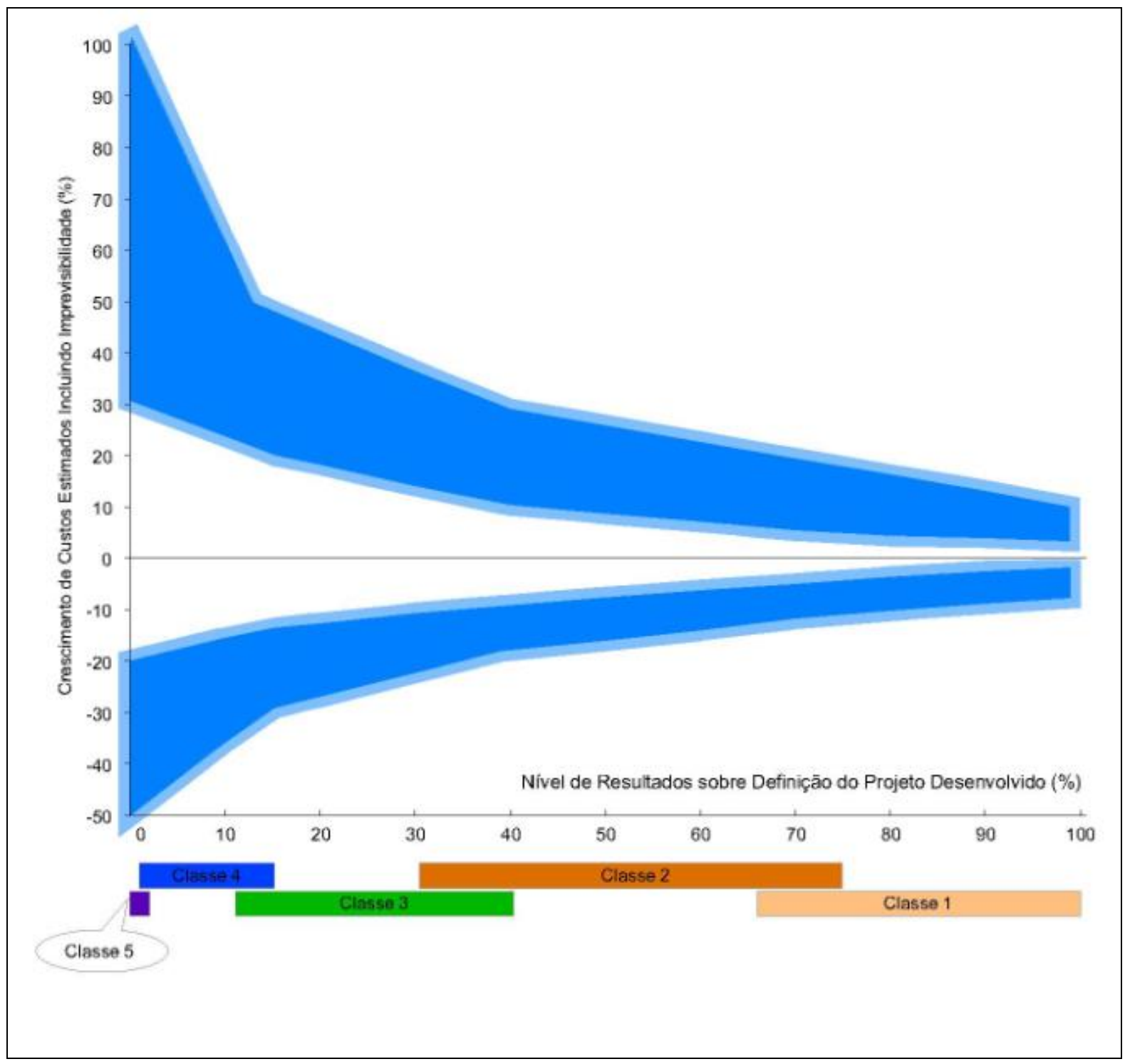


RP 56R-08(2012)

\begin{tabular}{|c|c|c|c|c|}
\hline & $\begin{array}{l}\text { Característica } \\
\text { Primária }\end{array}$ & \multicolumn{3}{|c|}{ Característica Secundária } \\
\hline $\begin{array}{l}\text { CLASSE DE } \\
\text { ESTIMATIVA }\end{array}$ & $\begin{array}{l}\text { NÍVEL DE MATURIDADE } \\
\text { DAS ENTREGAS } \\
\text { DENIFIDAS NO PROJETO } \\
\text { Expresso como \% da definição } \\
\text { completa }\end{array}$ & $\begin{array}{l}\text { USO FINAL } \\
\text { Finalidade típica de } \\
\text { estimativa }\end{array}$ & $\begin{array}{l}\text { METODOLOGIA } \\
\text { Método de estimativa típica }\end{array}$ & $\begin{array}{c}\text { INTERVALO DE } \\
\text { PRECISÃO ESPERADO } \\
\text { Variação típica em faixas de } \\
\text { baixa e alta [a] }\end{array}$ \\
\hline Classe 5 & $0 \%$ a $2 \%$ & $\begin{array}{l}\text { Viabilidade (ou } \\
\text { Screening) }\end{array}$ & $\begin{array}{l}\text { Fatores de capacidade, } \\
\text { modelos paramétricos, } \\
\text { julgamento ou analogia }\end{array}$ & $\begin{array}{l}\text { L: }-20 \% \text { a }-30 \% \\
H:+30 \% \text { a }+50 \%\end{array}$ \\
\hline Classe 4 & $1 \%$ a $15 \%$ & $\begin{array}{l}\text { Estudo de } \\
\text { viabilidade }\end{array}$ & $\begin{array}{c}\text { Modelos paramétricos, } \\
\text { Modelos de montagem } \\
\text { dirigida }\end{array}$ & $\begin{array}{l}\text { L: }-10 \% \text { a }-20 \% \\
H:+20 \% \text { a }+30 \%\end{array}$ \\
\hline Classe 3 & $10 \%$ a $40 \%$ & $\begin{array}{c}\text { Autorização } \\
\text { orçamentária ou } \\
\text { controle }\end{array}$ & $\begin{array}{l}\text { Custos unitários semi- } \\
\text { detalhados c/ itens em } \\
\text { nível de linha de } \\
\text { montagem }\end{array}$ & $\begin{array}{l}\text { L: }-5 \% \text { a }-15 \% \\
H:+10 \% \text { a }+20 \%\end{array}$ \\
\hline Classe 2 & $30 \%$ a $75 \%$ & $\begin{array}{c}\text { Controle ou } \\
\text { licitação/concurso }\end{array}$ & Custo unitário detalhado & $\begin{array}{l}L:-5 \% \text { a }-10 \% \\
H:+5 \% \text { a }+15 \%\end{array}$ \\
\hline Classe 1 & $65 \%$ a $100 \%$ & $\begin{array}{c}\text { Estimativa de } \\
\text { verificação ou } \\
\text { licitação/concurso }\end{array}$ & Custo unitário detalhado & $\begin{array}{l}L:-3 \% \text { a }-5 \% \\
H:+3 \% a+10 \%\end{array}$ \\
\hline
\end{tabular}




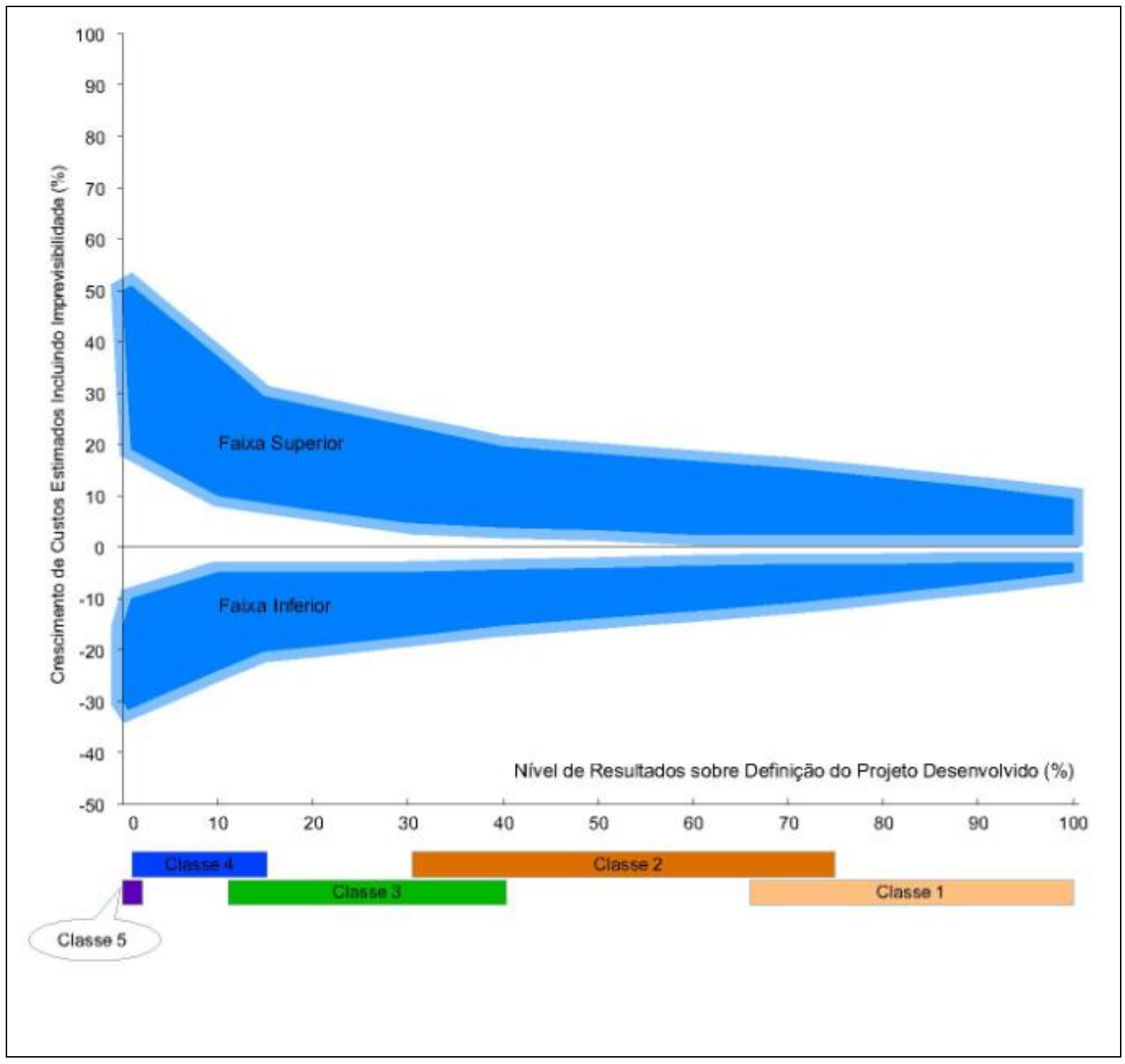




\section{APENDICE III - ACÓRDÃOS DO TCU}

Os trechos dos acórdãos do TCU relacionados aos temas gerenciamento de riscos e seguros e garantias são apresentados em ordem cronológica.

\section{Acórdão 1310/2013-TCU-Plenário, de 29/05/2013.}

Trecho do Acórdão:

9.1) recomendar ao Dnit que, com base no art. 250, inciso III, do Regimento Interno do TCU:

9.1.1) preveja doravante, nos empreendimentos licitados mediante o regime de contratação integrada, conforme faculta o art. $9^{\circ}$ da Lei 12.462/2011, "matriz de riscos" no instrumento convocatório e na minuta contratual, para tornar o certame mais transparente, fortalecendo, principalmente, a isonomia da licitação (art. 37, XXI da Constituição Federal; art. $1^{\circ}, \S^{\circ}$, IV da Lei n ${ }^{\circ} 12.462 / 2011$ ) e a segurança jurídica do contrato;

9.1.2) acrescente aos respectivos editais de obras que contemplem "seguro risco de engenharia", minuta do instrumento, contendo detalhamento das condições gerais e específicas cabíveis a obras rodoviárias, a exemplo dos modelos utilizados pelo setor privado, contemplando parâmetros que definam com precisão, entre outras coisas, os limites mínimos e máximos de indenização da apólice, valor dos bens e serviços a serem assegurados, bens e serviços não compreendidos no seguro, situações de risco a serem cobertas, riscos excluídos, âmbito geográfico da cobertura, formas de contratação e limites de responsabilidade, procedimentos para reclamação de sinistro, prazos prescricionais, vigência e cancelamento do contrato, pagamento do prêmio, início e fim de responsabilidade;

9.1.3) motive por meio de pesquisas de mercado mais aprofundadas, o valor previsto para esse tipo de apólice de seguro, a ser inserido no orçamento estimativo de futuros procedimentos licitatórios, na medida exata dos riscos envolvidos no respectivo objeto a ser licitado; 


\section{Acórdão 1465/2013-TCU-Plenário, de 12/06/2013.}

Trecho do Acórdão:

9.2. recomendar ao DNIT que:

9.2.1 preveja, doravante, nos empreendimentos a serem licitados mediante o regime de contratação integrada, previsto no art. $9^{\circ}$ da Lei no 12.462/2011, uma "matriz de riscos" no instrumento convocatório e na minuta contratual, de forma a tornar o certame mais transparente, fortalecendo, principalmente, a isonomia da licitação (art. 37, XXI, da Constituição Federal; art. $1^{\circ}, \S 1^{\circ}$, IV, da Lei $\left.n^{\circ} 12.462 / 2011\right)$ e a segurança jurídica do contrato (art. $5^{\circ}, \mathrm{XXXVI,} \mathrm{da} \mathrm{Constituição} \mathrm{Federal);}$

9.2.2 acrescente aos editais de obras que contemplem "seguro risco de engenharia" documento que reflita adequadamente os vários aspectos e particularidades que, a exemplo dos modelos adotados no setor privado, deverão compor as condições que a apólice abarcará, conforme as características de cada empreendimento a ser segurado;

\section{Acórdão 1510/2013-TCU-Plenário, de 19/06/2013.}

\section{Trecho do Acórdão:}

9.1. notificar a Infraero, com base no art. $179, \S 6^{\circ}$, do Regimento Interno do TCU, em razão de os futuros instrumentos convocatórios que venha a publicar, tendo em vista as irregularidades encontradas no Edital RDC Presencial 013/DALC/SBCT/2012, observe os seguintes requisitos para as licitações baseadas no regime de contratação integrada: (...)

9.1.3. a "matriz de riscos", instrumento que define a repartição objetiva de responsabilidades advindas de eventos supervenientes à contratação, na medida em que é informação indispensável para a caracterização do objeto e das respectivas responsabilidades contratuais, como também essencial para o dimensionamento das propostas por parte das licitantes, é elemento essencial e obrigatório do anteprojeto de engenharia, em prestígio ao definido no art. $9^{\circ}$, $§ 2^{\circ}$, inciso I, da Lei 12.462/2011, como ainda nos princípios da segurança jurídica, da isonomia, do julgamento objetivo, da eficiência e da obtenção da melhor proposta; 


\section{Acórdão 2745/2013-TCU-Plenário, de 09/10/2013.}

Trecho do Voto:

18. O segundo ponto objeto de contenda é acerca da legalidade da exigência contratual de estabelecer seguro garantia de $20 \%$ do valor total contratado. A contenda consiste na viabilidade de exigir tal montante a ser segurado, ponderando a disposição constante do art. 56 da Lei 8.666/93 que limita as garantias contratuais em 5\% (ou 10\%, conforme o caso). (...)

33. Existe nas contratações integradas um tripé de coerência na concepção dos empreendimentos. A matriz de riscos, os elementos de anteprojeto e os seguros devem ser idealizados de forma integrada; elaborados em um planejamento cuidadoso, de forma a, em conjunto, diminuírem os riscos da contratação. Quanto maior a liberdade conferida para o particular inovar e assumir riscos, menor será, em tese, a necessidade de detalhamento do anteprojeto e maior deverá ser a cobertura de seguros, para contrapor o potencial inadimplemento.

34. Em um modo de pensar, para as parcelas do empreendimento mais simples, em que a Administração tem meios de melhor detalhar a solução em anteprojeto (por absoluta simplicidade e pequeníssima vantagem de os particulares competirem em termos de metodologia construtiva), mais conveniente detalhá-los no anteprojeto e exigir a identidade em sua feitura. Os riscos dessa parcela, por conseguinte, serão da Administração.

35. Ao contrário, para aquelas frações mais complexas, tanto se libere as contratadas para propor, cada qual, a sua metodologia, quanto, por consequência, se transfira os respectivos riscos para o particular. No que se refere à viabilidade da cobertura de seguros, deve existir uma exigência contratual de seguro para mitigar essa potencial insegurança. É um imperativo que tanto confere maior estabilidade ao contrato (em termos de certeza no seu adimplemento), como viabiliza a própria precificação do risco. Mais que isso, os seguros proporcionais aos riscos são elementos indissociáveis para a segurança da oferta da melhor proposta.

36. Acredito, pelo que expus, que a contratação integrada tenha criado um novo cenário factual e mercadológico, então não coberto pelas possibilidades então previstas pelo art. 56 da Lei de Licitações, em seu rol de garantias. Desde que devidamente motivado e 
proporcional aos riscos assumidos, pode-se superar aqueles limites. Nesse ponto, entendo não haver reprimendas ao instrumento editalício criticado.

Trecho do Acórdão:

9.3. encaminhar cópia deste acórdão, acompanhado do relatório e voto que o fundamentam: (...)

9.3.7. ao Ministério do Planejamento, Orçamento e Gestão, tendo em vista disposição acerca do valor limite relativo ao seguro-garantia nas contratações integradas;

\section{Acórdão 2011/2015-TCU-Plenário, de 12/08/2015.}

Trecho do Acórdão:

9.2. dar ciência ao Dnit, nos termos do art. $4^{\circ}$ da Portaria-Segecex 13, de 27/4/2011:

9.2.1. de que a redução da garantia contratual de $30 \%$ para $10 \%$ verificada nos certames mais recentes do BR-Legal, a exemplo dos editais 132/2014-00, 131/2014-00 e 130/201400, aumenta a exposição da administração ao risco de prejuízos em caso de inadimplemento por parte das empresas contratadas, em afronta ao inciso XII do art. $8^{\circ}$ do Decreto 7.581/2011; 


\title{
APÊNDICE IV - LICITAÇÕES CONTRATAÇÃO INTEGRADA
}

\author{
Apresenta-se em ordem cronológica os certames na modalidade contratação integrada que
}

foram homologados até 2014 por órgão/entidade.

\begin{tabular}{|c|c|c|c|c|c|}
\hline Edital & Objeto & $\begin{array}{l}\text { Matriz } \\
\text { de } \\
\text { risco }\end{array}$ & \begin{tabular}{c|} 
Reserva de \\
Contingência*
\end{tabular} & Seguros & Garantias \\
\hline \multicolumn{6}{|l|}{ DNIT } \\
\hline 0489/12-00 & $\begin{array}{l}\text { Contratação integrada de empresa(s) para a prestação de serviço técnico } \\
\text { especializado de engenharia para elaboração de projeto básico e executivo e } \\
\text { execução das obras de implantação e pavimentação da rodovia na BR-163/PA. }\end{array}$ & Não & Não & Sim & Não \\
\hline $0750 / 12-00$ & $\begin{array}{l}\text { Contratação Integrada de empresa especializada para a prestação de serviço de } \\
\text { Elaboração de Projeto Básico e de Executivo de Engenharia e Execução das Obras } \\
\text { de Restauração da Pista Existente, Adequação de Capacidade, Melhoria da } \\
\text { Segurança com Eliminação de Pontos Críticos, Construção de Contornos } \\
\text { Rodoviários, Duplicação, Implantação de Sistema de Iluminação Pública e } \\
\text { Construção de Obras-de-Arte Especiais, da Rodovia BR-163/364/MT. }\end{array}$ & Não & Não & Sim & Não \\
\hline $0751 / 12-00$ & $\begin{array}{l}\text { Contratação de empresa para elaboração de Projeto Executivo e Execução das } \\
\text { Obras Complementares à Ponte do Rio Madeira, incluindo Conjunto Habitacional } \\
\text { Popular e Dolphin`s adicionais, na BR 319/RO. }\end{array}$ & Não & Não & Sim & Não \\
\hline $0752 / 12-00$ & $\begin{array}{l}\text { Contratação de empresa para elaboração de Projeto Executivo e Execução das } \\
\text { Obras de Implantação das Instalações de Fronteira - Aduana, Brasil e a Guiana } \\
\text { Francesa, na BR-156/AP. }\end{array}$ & Não & Não & Sim & Não \\
\hline 0799/12-00 & $\begin{array}{l}\text { Contratação de empresas para Elaboração do projeto básico e executivo e execução } \\
\text { das obras de duplicação, restauração da pista existente, implantação de ruas laterais } \\
\text { e restauração/construção de obras de arte especiais na BR-158 e BR-287 (travessia } \\
\text { urbana de Santa Maria). }\end{array}$ & Não & Não & Sim & Não \\
\hline 0851/12-00 & $\begin{array}{l}\text { Contratação de empresa para elaboração de projeto básico e executivo de } \\
\text { engenharia e execução dos serviços técnicos de aplicação e manutenção de } \\
\text { dispositivos de segurança e de sinalização rodoviária, no âmbito do programa } \\
\text { nacional de segurança e sinalização rodoviária - BR-Legal, nas rodovias BR's - } \\
\text { 040/050/120/135/146/153/259/262/356/364/ 365/381/452/482/494 do estado de } \\
\text { Minas Gerais e BR's-101/354/356/393/465/485/493/495 do estado do Rio de } \\
\text { Janeiro, subdividida em 06 (seis) lotes, totalizando } 3.456,1 \mathrm{~km} \text {. }\end{array}$ & Não & Não & Sim & Sim \\
\hline $0852 / 12-00$ & $\begin{array}{l}\text { Contratação de empresa para a elaboração de projeto básico e executivo de } \\
\text { engenharia e execução dos serviços técnicos de aplicação e manutenção de } \\
\text { dispositivos de segurança e de sinalização rodoviária, no âmbito do programa } \\
\text { nacional de segurança e sinalização rodoviária - BR-Legal, nas rodovias BR's- } \\
\text { 060/158/364/070 do estado de Goiás, BR's-070/163/174/364 do estado de Mato } \\
\text { Grosso e BR's-020/060/070/080/251 do Distrito Federal, pelo regime diferenciado } \\
\text { de contratação - RDC, subdividida em } 07 \text { (sete) lotes, totalizando } 3.637,80 \mathrm{~km} \text {. } \\
\end{array}$ & Não & Não & Sim & Sim \\
\hline 0853/12-00 & $\begin{array}{l}\text { Contratação integrada de empresa para a elaboração de projeto básico e executivo } \\
\text { de engenharia e execução dos serviços técnicos de aplicação e manutenção de } \\
\text { dispositivos de segurança e de sinalização rodoviária, no âmbito do programa } \\
\text { nacional de segurança e sinalização rodoviária - BR-Legal, nas rodovias BR's- } \\
020 / 116 / 122 / 222 / 226 / 402 / 403 / 404 \text { do estado do Ceará e BR's-101/104/232/408 do } \\
\text { estado de Pernambuco, pelo regime diferenciado de contratação - RDC, subdividida } \\
\text { em 05 (cinco) lotes, totalizando } 2.364,40 \mathrm{~km} \text {. }\end{array}$ & Não & Não & Sim & Sim \\
\hline $0854 / 12-00$ & $\begin{array}{l}\text { Contratação de empresa para a elaboração de projeto básico e executivo de } \\
\text { engenharia e execução dos serviços técnicos de aplicação e manutenção de } \\
\text { dispositivos de segurança e de sinalização rodoviária, no âmbito do programa } \\
\text { nacional de segurança e sinalização rodoviária - BR-Legal, nas rodovias BR's- } \\
317 / 364 \text { do estado do Acre e BR's-174/319/364/421/425/429/435 do estado de } \\
\text { Rondônia, pelo regime diferenciado de contratação - RDC, subdividida em } 05 \\
\text { (cinco) lotes, totalizando 3.075,60 km. }\end{array}$ & Não & Não & Sim & Sim \\
\hline 0023/13-00 & $\begin{array}{l}\text { Contratação de empresa para elaboração de projeto básico e de projeto executivo de } \\
\text { engenharia e execução das obras de restauração da pista existente, de adequação de } \\
\text { capacidade, melhoria da segurança com eliminação de pontos críticos, construção } \\
\text { de contornos rodoviários, duplicação, implantação de sistemas de iluminação } \\
\text { pública e construção de obras de arte especiais, na rodovia BR-163/364/MT. }\end{array}$ & Não & Não & Sim & Não \\
\hline 0040/13-00 & $\begin{array}{l}\text { Contratação de empresa para elaboração do projeto básico e executivo e execução } \\
\text { das obras para adequação da passagem urbana na rodovia BR-163/PR com } \\
\text { execução de pavimentação de ruas marginais, interseções em desníveis e passarelas } \\
\text { no perímetro urbano de Marechal Cândido Rondon/PR. }\end{array}$ & Não & Não & Sim & Não \\
\hline 0041/13-00 & $\begin{array}{l}\text { Contratação para elaboração dos projetos básico e executivo e execução das obras } \\
\text { prioritárias de melhoria de capacidade da BR-290/RS, incluindo a duplicação. }\end{array}$ & Não & Não & Sim & Não \\
\hline
\end{tabular}




\begin{tabular}{|c|c|c|c|c|c|}
\hline Edital & Objeto & $\begin{array}{l}\text { Matriz } \\
\text { de } \\
\text { risco }\end{array}$ & $\begin{array}{l}\text { Reserva de } \\
\text { Contingência* }\end{array}$ & Seguros & Garantias \\
\hline 0042/13-00 & $\begin{array}{l}\text { Contratação de empresa para elaboração de projeto básico, executivo e execução } \\
\text { das obras de implantação e pavimentação com obras de arte especiais na rodovia } \\
\text { BR-487/PR. }\end{array}$ & Não & Não & Sim & Não \\
\hline $0052 / 13-00$ & $\begin{array}{l}\text { Contratação Integrada de Empresa para a Elaboração de Projeto Básico e Executivo } \\
\text { de Engenharia e Execução dos Serviços Técnicos de Aplicação e Manutenção de } \\
\text { Dispositivos de Segurança e de Sinalização Rodoviária, no âmbito do Programa } \\
\text { Nacional de Segurança e Sinalização Rodoviária - BR-Legal, nas rodovias BR- } \\
\text { 116/230/304 do Estado do Ceará, BR-110/116/232/316/407/423/424/428 do Estado } \\
\text { de Pernambuco, e BR-101/235 do Estado de Sergipe pelo regime diferenciado de } \\
\text { contratação - RDC, subdividida em 05 (cinco) lotes, totalizando 2.182,20 km. }\end{array}$ & Não & Não & Sim & Sim \\
\hline 0091/13-00 & $\begin{array}{l}\text { Contratação de empresa(s) para elaboração do projeto básico e executivo e execução } \\
\text { das obras de implantação e pavimentação com obras de arte especiais, na rodovia } \\
\text { BR-158/PR. }\end{array}$ & Não & Não & Sim & Não \\
\hline 0105/13-00 & $\begin{array}{l}\text { Contratação de empresa visando o desenvolvimento dos projetos básico e executivo, } \\
\text { a execução de obras e todas as demais operações necessárias e suficientes para a } \\
\text { entrega final da ponte sobre o Rio Madeira em Abunã e de seus acessos na BR- } \\
\text { 364/RO. }\end{array}$ & Não & Não & Sim & Não \\
\hline 0128/13-00 & $\begin{array}{l}\text { Contratação de empresas para elaboração do projeto básico e executivo e execução } \\
\text { das obras de duplicação, restauração com melhoramentos e obras-de-arte especiais, } \\
\text { na rodovia BR-101/PE. }\end{array}$ & Não & Não & Sim & Não \\
\hline 0165/13-00 & $\begin{array}{l}\text { Contratação de empresas para Elaboração dos Projetos Básico e Executivo e } \\
\text { Execução das Obras de Adequação de Capacidade da Rodovia BR-381/MG (Norte), } \\
\text { incluindo Duplicação, Melhoramentos e Ampliação de Capacidade e Segurança de } \\
\text { segmentos do trecho Div. ES/MG - Div. MG/SP, subtrecho Entro BR-116/MG } \\
\text { (Governador Valadares) - Entro MG-020 (Av. Cristiano Machado /Belo Horizonte), } \\
\text { segmento Km 155,4 - Km 458,4, subdividido em } 11 \text { (onze) Lotes. }\end{array}$ & Sim & Sim & Sim & Sim \\
\hline 0212/13-00 & $\begin{array}{l}\text { Contratação de empresa para elaboração dos projetos básico e executivo e execução } \\
\text { das obras de implantação e pavimentação, incluindo os encabeçamentos das pontes, } \\
\text { na rodovia BR-242/TO - Lote } 04 \text {. }\end{array}$ & Sim & Sim & Sim & Não \\
\hline 0213/13-00 & $\begin{array}{l}\text { Contratação de empresa para elaboração dos projetos básico e executivo e execução } \\
\text { das obras de implantação e pavimentação, incluindo os encabeçamentos das pontes, } \\
\text { na rodovia BR-242/TO - Lote } 05 \text {. }\end{array}$ & Sim & Sim & Sim & Não \\
\hline 0232/13-00 & $\begin{array}{l}\text { Contratação de empresa para elaboração dos projetos básico e executivo e execução } \\
\text { das obras de recuperação estrutural das pontes de acesso, cais flutuantes de } \\
\text { atracação das torres e do Roadway, bem como, das obras de restauração, adequação } \\
\text { e modernização da área retroportuária, além da requalificação do porto de Manaus } \\
\text { para a Copa do Mundo de } 2014 \text {. }\end{array}$ & Sim & Não & Sim & Sim \\
\hline 0267/13-00 & $\begin{array}{l}\text { Contratação de empresa para elaboração do projeto básico e executivo e execução } \\
\text { das obras de duplicação, restauração com melhoramentos e Obras-de-Arte } \\
\text { Especiais, BR-493/RJ. }\end{array}$ & Sim & Sim & Sim & Não \\
\hline 0268/13-00 & $\begin{array}{l}\text { Contratação integrada de empresa especializada para a prestação de serviços de } \\
\text { elaboração de projeto básico e de projeto executivo de engenharia e execução das } \\
\text { obras de restauração da pista existente, de adequação de capacidade, melhoria de } \\
\text { segurança com eliminação de pontos críticos, duplicação e construção de Obras de } \\
\text { Arte especiais na rodovia BR-163/364/MT. }\end{array}$ & Sim & Sim & Sim & Não \\
\hline $0334 / 13-00$ & $\begin{array}{l}\text { Contratação Integrada de Empresa para a Elaboração de Projeto Básico e Executivo } \\
\text { de Engenharia e Execução dos Serviços Técnicos de Aplicação e Manutenção de } \\
\text { Dispositivos de Segurança e de Sinalização Rodoviária, no âmbito do Programa } \\
\text { Nacional de Segurança e Sinalização Rodoviária - BR-Legal, nas rodovias BR- } \\
\text { 101/116/158/285/386/392/468/472 do Estado do Rio Grande do Sul, BR- } \\
\text { 010/153/226/230/235/242 do Estado de Tocantins, pelo regime diferenciado de } \\
\text { contratação - RDC, subdividida em } 6 \text { (seis) lotes, totalizando 3.740,50 km. }\end{array}$ & Sim & Não & Sim & Sim \\
\hline 0335/13-00 & $\begin{array}{l}\text { Contratação Integrada de Empresa para a Elaboração de Projeto Básico e Executivo } \\
\text { de Engenharia e Execução dos Serviços Técnicos de Aplicação e Manutenção de } \\
\text { Dispositivos de Segurança e de Sinalização Rodoviária, no âmbito do Programa } \\
\text { Nacional de Segurança e Sinalização Rodoviária - BR-Legal, nas rodovias BR- } \\
\text { 153/158/163/272/277/280/369/373/376/466/467/469/476/487 do Estado do Paraná e } \\
\text { BR-101/104/110/116/230/361/405/412/426/427/434 do Estado da Paraíba pelo } \\
\text { regime diferenciado de contratação - RDC, subdividida em } 6 \text { (seis) lotes, } \\
\text { totalizando 3.114,30 }\end{array}$ & Sim & Não & Sim & Sim \\
\hline 0336/13-00 & $\begin{array}{l}\text { Contratação Integrada de Empresa para a Elaboração de Projeto Básico e Executivo } \\
\text { de Engenharia e Execução dos Serviços Técnicos de Aplicação e Manutenção de } \\
\text { Dispositivos de Segurança e de Sinalização Rodoviária, no âmbito do Programa } \\
\text { Nacional de Segurança e Sinalização Rodoviária - BR-Legal, nas rodovias BR- } \\
101 / 158 / 459 / 488 \text { do Estado de São Paulo, BR-101/153/158/163/280/282/470 do } \\
\text { Estado de Santa Catarina e BR-101/104/110/316/416/423/424 do Estado de Alagoas } \\
\text { pelo regime diferenciado de contratação - RDC, subdividida em } 6 \text { (seis) lotes, } \\
\text { totalizando } 2.590,10 \mathrm{~km} \text {. }\end{array}$ & Sim & Não & Sim & Sim \\
\hline
\end{tabular}




\begin{tabular}{|c|c|c|c|c|c|}
\hline Edital & Objeto & $\begin{array}{l}\text { Matriz } \\
\text { de } \\
\text { risco }\end{array}$ & $\begin{array}{c}\text { Reserva de } \\
\text { Contingência* }\end{array}$ & Seguros & Garantias \\
\hline 0337/13-00 & $\begin{array}{l}\text { Contratação Integrada de Empresa para a Elaboração de Projeto Básico e Executivo } \\
\text { de Engenharia e Execução dos Serviços Técnicos de Aplicação e Manutenção de } \\
\text { Dispositivos de Segurança e de Sinalização Rodoviária, no âmbito do Programa } \\
\text { Nacional de Segurança e Sinalização Rodoviária - BR-Legal, nas rodovias BR- } \\
\text { 101/110/226/304/405/406/427 do Estado do Rio Grande do Norte e BR- } \\
\text { 101/153/158/293/470/471/473 do Estado do Rio Grande do Sul, pelo regime } \\
\text { diferenciado de contratação - RDC, subdividida em } 6 \text { (seis) lotes, totalizando } \\
2.742,30 \mathrm{~km} \text {. }\end{array}$ & Sim & Não & Sim & Sim \\
\hline 0338/13-00 & 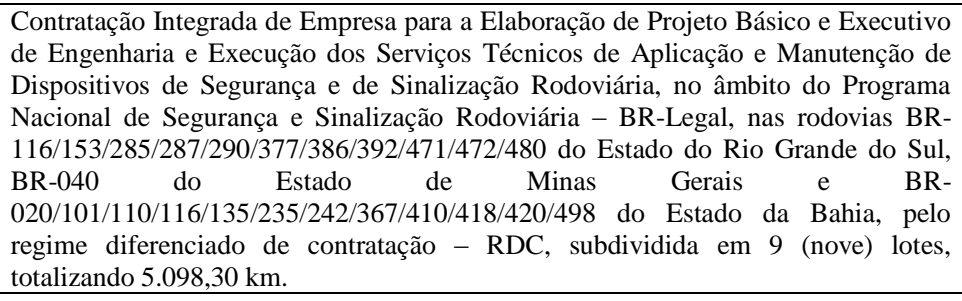 & Sim & Não & Sim & Sim \\
\hline 0412/13-00 & $\begin{array}{l}\text { Contratação integrada de empresa para a prestação de serviço técnico especializado } \\
\text { de engenharia para elaboração de projeto básico e executivo e execução das obras } \\
\text { de construção da nova aldeia indígena no município de Estrela/RS. }\end{array}$ & Sim & Não & Sim & Não \\
\hline 0537/13-00 & $\begin{array}{l}\text { Contratação Integrada de empresa para a prestação de serviços técnicos } \\
\text { especializados de engenharia para Elaboração dos Projetos Básico e Executivo de } \\
\text { Engenharia e Execução das Obras de Construção de uma Segunda Ponte sobre o } \\
\text { Rio Guaíba e Acessos, na BR-116/290/RS }\end{array}$ & Sim & Sim & Sim & Sim \\
\hline 0046/14-00 & $\begin{array}{l}\text { Contratação integrada de empresa para desenvolvimento dos Projetos Básico e } \\
\text { Executivo e execução das obras e demais operações necessárias e suficientes para a } \\
\text { construção da Ponte Internacional sobre o rio Paraná ligando o Brasil (Foz do } \\
\text { Iguaçu) e o Paraguai (Presidente Franco). }\end{array}$ & Sim & Sim & Sim & Sim \\
\hline 0102/14-00 & $\begin{array}{l}\text { Contratação Integrada de empresas para Elaboração dos Projetos Básico e } \\
\text { Executivo e Execução das Obras de Adequação de Capacidade da Rodovia BR- } \\
\text { 381/MG (Norte), incluindo Duplicação, Melhoramentos e Ampliação de } \\
\text { Capacidade e Segurança de segmentos do trecho Divisa ES/MG - Divisa MG/SP, } \\
03 \text { (três) lotes. }\end{array}$ & Sim & Sim & Sim & Sim \\
\hline 0130/14-00 & $\begin{array}{l}\text { Contratação de Empresa para a Elaboração de Projeto Básico e Executivo de } \\
\text { Engenharia e Execução dos Serviços Técnicos de Aplicação e Manutenção de } \\
\text { Dispositivos de Segurança e de Sinalização Rodoviária, no âmbito do Programa } \\
\text { Nacional de Segurança e Sinalização Rodoviária - BR-Legal, nas rodovias BR- } \\
\text { 116/135/242/324 do estado da Bahia, BR-010/153/222/230/308/316/422 do estado } \\
\text { do Pará, subdividida em } 6 \text { (seis) lotes, totalizando } 2.470,10 \mathrm{~km} \text {. }\end{array}$ & Sim & Não & Sim & Sim \\
\hline 0131/14-00 & $\begin{array}{l}\text { Contratação de Empresa para a Elaboração de Projeto Básico e Executivo de } \\
\text { Engenharia e Execução dos Serviços Técnicos de Aplicação e Manutenção de } \\
\text { Dispositivos de Segurança e de Sinalização Rodoviária, no Âmbito Do Programa } \\
\text { Nacional De Segurança e Sinalização Rodoviária - BR-Legal, Nas Rodovias BR- } \\
\text { 030/101/122/135/349/415 Do Estado Da Bahia, Br-174/230/317/319 Do Estado Da } \\
\text { Amazonas, Br-174/210/401/432 Do Estado De Roraima, Subdividida Em } 7 \text { (Sete) } \\
\text { Lotes, Totalizando 2.919,90 Km. }\end{array}$ & Sim & Não & Sim & Sim \\
\hline 0139/14-00 & $\begin{array}{l}\text { Contratação Integrada de empresa para a prestação de serviços técnicos } \\
\text { especializados de engenharia para a Elaboração dos Projetos Básico e Executivo e } \\
\text { Execução das Obras de Restauração na Rodovia BR 155/PA. }\end{array}$ & Sim & Sim & Sim & Sim \\
\hline 0272/14-00 & $\begin{array}{l}\text { Contratação de serviços técnicos especializados de engenharia para a Elaboração do } \\
\text { Projeto Básico e Executivo e Execução das Obras de Implantação e Pavimentação } \\
\text { de Ruas Laterais com Transposição da Rodovia por Obras de Artes Especiais, com } \\
\text { Melhoramentos para Adequação de Capacidade e Segurança na Rodovia BR } \\
\text { 364/RO. }\end{array}$ & Sim & Sim & Sim & Sim \\
\hline 0363/14-00 & $\begin{array}{l}\text { Contratação Integrada de Empresa para a Prestação de Serviços Técnicos } \\
\text { Especializados de Engenharia para Elaboração do Projeto Básico e Executivo e } \\
\text { Execução das Obras Remanescentes de Implantação do Plano Rodoviário de Juiz de } \\
\text { Fora (Adequação da Capacidade de Tráfego), incluindo OAE's, na rodovia BR- } \\
\text { 440/MG. }\end{array}$ & Sim & Sim & Sim & Sim \\
\hline 0365/14-00 & $\begin{array}{l}\text { Contratação Integrada de empresa para Elaboração do Projeto Básico e Executivo } \\
\text { de Engenharia e Execução das Obras para Duplicação de Rodovia e Restauração da } \\
\text { Pista Existente e Obras-de-Arte Especiais na Rodovia BR-262/ES }\end{array}$ & Sim & Sim & Sim & Sim \\
\hline 0599/14-00 & $\begin{array}{l}\text { Contratação Integrada de empresa para Elaboração dos Projetos Básico e Executivo } \\
\text { e Execução das Obras de Implantação e Pavimentação, incluindo Obras de Arte } \\
\text { Especiais, na rodovia BR-447/ES }\end{array}$ & Sim & Sim & Sim & Sim \\
\hline
\end{tabular}




\begin{tabular}{|c|c|c|c|c|c|}
\hline Edital & Objeto & \begin{tabular}{c|}
$\begin{array}{c}\text { Matriz } \\
\text { de } \\
\text { risco }\end{array}$ \\
\end{tabular} & $\begin{array}{l}\text { Reserva de } \\
\text { Contingência* }\end{array}$ & Seguros & Garantias \\
\hline 0693/14-00 & $\begin{array}{l}\text { Contratação de Empresa ou Consórcio de Empresas para a Elaboração dos Projetos } \\
\text { de Engenharia, Construção, Manutenção, Conservação e Execução dos Serviços de } \\
\text { Coleta de Dados de Veículos Pesados através de PostosIntegrados Automatizados } \\
\text { de Fiscalização - PIAF, no âmbito do Plano Nacional de Pesagem, nas rodovias: } \\
\text { BR-101/RN, BR-226/RN, BR-304/RN, BR-135/MA, BR-316/MA, BR-020/PI, BR- } \\
\text { 135/PI, BR-230/PI e BR-316/PI, subdividida em 06 (seis) lotes, totalizando } \\
\text { 11(onze) PIAF. }\end{array}$ & Sim & Não & Sim & Sim \\
\hline 0695/14-00 & $\begin{array}{l}\text { Contratação Integrada de Empresa ou Consórcio de Empresas para a Elaboração dos } \\
\text { Projetos de Engenharia, Construção, Manutenção, Conservação e Execução dos } \\
\text { Serviços de Coleta de Dados de Veículos Pesados através de } \\
\text { Postos Integrados Automatizados de Fiscalização - PIAF, no âmbito do Plano } \\
\text { Nacional de Pesagem, nas rodovias: BR-010/PA, BR-230/PA, BR-163/PA, BR- } \\
\text { 163/MT, BR-158/MS e BR-364/RO, subdividida em 05 (cinco) lotes, totalizando 07 } \\
\text { (sete) PIAF. }\end{array}$ & Sim & Não & Sim & Sim \\
\hline 0696/14-00 & $\begin{array}{l}\text { Contratação Integrada de Empresa ou Consórcio de Empresas para a Elaboração } \\
\text { dos Projetos de Engenharia, Construção, Manutenção, Conservação e Execução dos } \\
\text { Serviços de Coleta de Dados de Veículos Pesados através de } \\
\text { Postos Integrados Automatizados de Fiscalização - PIAF, no âmbito do Plano } \\
\text { Nacional de Pesagem, nas rodovias: BR-476/PR, BR-163/PR, BR-158/RS, BR- } \\
\text { 472/RS e BR-280/SC, subdividida em 04 (quatro) lotes, totalizando 06 (seis) PIAF. }\end{array}$ & Sim & Não & Sim & Sim \\
\hline \multicolumn{6}{|l|}{ VALEC } \\
\hline $002 / 2012$ & $\begin{array}{l}\text { Contratação Integrada de Elaboração de Projeto Executivo e Execução de obras } \\
\text { remanescentes, bem como manutenção da Ferrovia Norte-Sul, km } 719-\mathrm{km} \\
1.029,89 \text {. }\end{array}$ & Não & Não & Sim & Não \\
\hline $003 / 2012$ & $\begin{array}{l}\text { Contratação Integrada de Elaboração de Projeto Executivo e Execução de obras e } \\
\text { serviços remanescentes necessários para complementar o trecho ferroviário } \\
\text { compreendido entre o km 1.029,89 (Córrego Chicote/TO) e o km 1.294,00 (Pátio de } \\
\text { Uruaçu/GO) da Ferrovia Norte-Sul, bem como manutenção do referido trecho. }\end{array}$ & Não & Não & Sim & Não \\
\hline $004 / 2012$ & $\begin{array}{l}\text { Contratação Integrada de Elaboração de Projeto Executivo e Execução de obras e } \\
\text { serviços remanescentes necessários para complementar o trecho ferroviário } \\
\text { compreendido entre o km 1.294,00 (Pátio de Uruaçu/GO) e o km 1.574,00 (Porto } \\
\text { Seco) da Ferrovia Norte-Sul, bem como manutenção do referido trecho. }\end{array}$ & Não & Não & Sim & Não \\
\hline $001 / 2013$ & $\begin{array}{l}\text { Contratação integrada de elaboração de Projeto Executivo e execução de obras de } \\
\text { engenharia necessários para implantação do Pátio de Anápolis, localizado entre o } \\
\text { km 9+600 e o km 13+360 da Ferrovia Norte-Sul - FNS. }\end{array}$ & Não & Não & Sim & Não \\
\hline $006 / 2014$ & $\begin{array}{l}\text { Contratação de empresa para elaboração dos projetos básico e executivo e execução } \\
\text { das obras e serviços remanescentes, localizados no município de Rio Verde/GO, } \\
\text { posicionado no km } 357+800 \text { ao km } 364+172 \text { e a implantação da grade (lastro, } \\
\text { dormentes e trilhos) entre os km } 315+800 \text { e } 394+900 \text { da Extensão Sul, da Ferrovia } \\
\text { Norte-Sul. }\end{array}$ & Sim & Não & Sim & Não \\
\hline \multicolumn{6}{|l|}{ Infraero } \\
\hline \begin{tabular}{c|} 
RDC \\
Presencial - \\
013/DALC/ \\
SBCT/2012
\end{tabular} & $\begin{array}{l}\text { Planejamento, gerenciamento e execução integral de todas as fases do } \\
\text { empreendimento de reforma e ampliação do terminal de passageiros, do sistema } \\
\text { viário de acesso e demais obras complementares do Aeroporto Internacional Afonso } \\
\text { Pena, em São José dos Pinhais/PR, compreendendo a elaboração e desenvolvimento } \\
\text { dos projetos de engenharia, execução de obras e serviços de engenharia, montagens, } \\
\text { realização de testes e pré-operação de equipamentos e sistemas envolvidos no } \\
\text { escopo do empreendimento. }\end{array}$ & Não & Não & Sim & Não \\
\hline \multicolumn{6}{|c|}{ Ministério da Integração Nacional } \\
\hline $004 / 2013$ & $\begin{array}{l}\text { Elaboração de projeto básico, projeto executivo e construção dos núcleos } \\
\text { habitacionais das VPRs - Vilas Produtivas Rurais, nos estados do Ceará e Paraíba, } \\
\text { do Projeto de Integração do rio São Francisco com bacias hidrográficas do Nordeste } \\
\text { Setentrional - PISF. }\end{array}$ & Sim & Não & Sim & Não \\
\hline $\mathbf{S}$ & Portos & & & & \\
\hline
\end{tabular}




\begin{tabular}{|c|c|c|c|c|c|}
\hline Edital & Objeto & $\begin{array}{c}\text { Matriz } \\
\text { de } \\
\text { risco }\end{array}$ & $\begin{array}{l}\text { Reserva de } \\
\text { Contingência* }\end{array}$ & Seguros & Garantias \\
\hline $\begin{array}{c}\text { RDC } \\
\text { Presencial } \\
\text { SEP/PR N }^{\circ} \\
04 / 2014\end{array}$ & $\begin{array}{l}\text { Contratação de empresa ou consórcio de empresas para a Elaboração dos Projetos } \\
\text { Básico e Executivo e a Execução da Obra de Dragagem por resultado para } \\
\text { ampliação do Acesso da Infraestrutura Aquaviária ao Complexo Portuário do Rio de } \\
\text { Janeiro/RJ, bem como o fornecimento e instalação de novos Cabos Submarinos de } \\
\text { energia elétrica, incluindo instalação do Sistema de Geração de Energia em } \\
\text { Emergência, fornecimento e instalação de novos Alimentadores de Energia Elétrica } \\
\text { e nova Adutora de Água Potável. }\end{array}$ & Sim & Não & Não & Não \\
\hline
\end{tabular}

* Reserva de Contingência - considerada nos empreendimentos que tiveram a reserva de contingência alocada no orçamento, de acordo com Instrução de Serviço/DG nº 01, de 2/1/2014. 